\title{
Electromagnetic Mixed-Waste Processing System for Asbestos Decontamination
}

\section{Topical Report}

\author{
DISCLAIMER
}

\begin{abstract}
This report was prepared as an account of work sponsored by an agency of the United States Government. Neither the United States Government nor any agency thereof, nor any of their employees, makes any warranty, express or implied, or assumes any legal liability or responsibility for the accuracy, completeness, or usefulness of any information, apparatus, product, or process disclosed, or represents that its use would not infringe privately owned rights. Reference herein to any specific commercial product, process, or service by trade name, trademark, manufacturer, or otherwise does not necessarily constitute or imply its endorsement, recommendation, or favoring by the United States Government or any agency thereof. The views and opinions of authors expressed herein do not necessarily state or reflect those of the United States Government or any agency thereof.
\end{abstract}

\section{Aprtl 1995}

Work Performed Under Contract No.: DE-AC21-94MC29249

U.S. Department of Energy

Office of Environmental Management

Office of Technology Development

Washington, DC
For

\author{
U.S. Department of Energy \\ Office of Fossil Energy \\ Morgantown Energy Technology Center \\ Morgantown, West Virginia
}

By

KAI Technologies, Inc.

Wobum, Massachusetts 


\section{DISCLAIMER}

This report was prepared as an account of work sponsored by an agency of the United States Government. Neither the United States Government nor any agency thereof, nor any of their employees, makes any warranty, express or implied, or assumes any legal liability or responsibility for the accuracy, completeness, or usefulness of any information, apparatus, product, or process disclosed, or represents that its use would not infringe privately owned rights. Reference herein to any specific commercial product, process, or service by trade name, trademark, manufacturer, or otherwise does not necessarily constitute or imply its endorsement, recommendation, or favoring by the United States Government or any agency thereof. The views and opinions of authors expressed herein do not necessarily state or reflect those of the United States Government or any agency thereof.

This report has been reproduced directly from the best available copy.

Available to DOE and DOE contractors from the Office of Scientific and Technical Information, 175 Oak Ridge Turnpike, Oak Ridge, TN 37831; prices available at (615) 576-8401.

Available to the public from the National Technical Information Service, U.S. Department of Commerce, 5285 Port Royal Road, Springfield, VA 22161; phone orders accepted at (703) 487-4650. 


\section{DISCLAIMER}

Portions of this document may be illegible in electronic image products. Images are produced from the best available original document. 


\title{
Electromagnetic Mixed-Waste Processing System for Asbestos Decontamination
}

\author{
Topical Report
}

Work Performed Under Contract No.: DE-AC21-94MC29249

U.S. Department of Energy

Office of Environmental Management

Office of Technology Development

1000 Independence Avenue

Washington, DC 20585
For

U.S. Department of Energy

Office of Fossil Energy

Morgantown Energy Technology Center P.O. Box 880 Morgantown, West Virginia 265070880

\author{
By \\ KAI Technologies, Inc. \\ P.O. Box 3059 \\ Administrative Office \\ Woburn, Massachusetts 01888-1859 \\ 170 West Road, Suite 7 \\ Portsmouth, New Hampshire 03801
}




\begin{abstract}
The first phase of a program to develop and demonstrate a costeffective, integrated process for remediation of asbestos-containing material that is contaminated with organics, heavy metals, and radioactive compounds was successfully completed. Laboratory scale tests were performed to demonstrate initial process viability for asbestos conversion, organics removal, and radionuclide and heavy metal removal. All success criteria for the laboratory tests were met. 1) Ohio DSI demonstrated greater than $99 \%$ asbestos conversion to amorphous solids using their commercial process. 2) KAI demonstrated $90 \%$ removal of organics from the asbestos suspension. 3) Westinghouse STC achieved the required metals removal criteria on a laboratory scale (e.g., 92\% removal of uranium from solution, resin loadings of 0.6 equivalents per liter, and greater than $50 \%$ regeneration of resin in a batch test.)
\end{abstract}

Using the information gained in the laboratory tests, the process was reconfigured to provide the basis for the mixed waste remediation system. An integrated process is conceptually developed, and a Phase 2 program plan is proposed to provide the bench-scale development needed in order to refine the design basis for a pilot processing system. 


\section{CONTENTS}

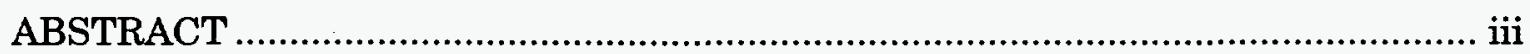

LIST OF FIGURES ................................................................................... vii

LIST OF TABLES.......................................................................................

ABBREVIATIONS, ACRONYMS, AND TECHNICAL TERMS ...........................

1. EXECUTIVE SUMMARY .....................................................................

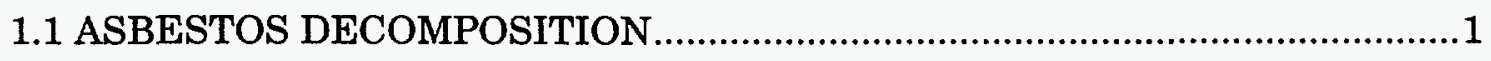

1.2 REMOVAL OF HEAVY METALS AND RADIONUCLIDES .........................2

1.3 RADIO FREQUENCY DEVOLATILIZATION OF ORGANICS AND COLD PLASMA DESTRUCTION OF SURROGATE PCB ...........................5

1.4 RECOMMENDED MIXED WASTE PROCESSING SYSTEM DESCRIPTION 7

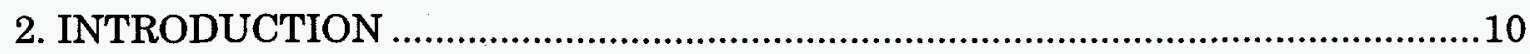

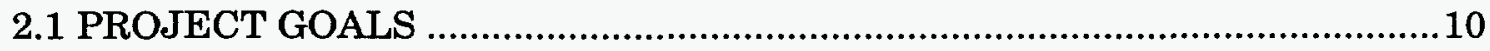

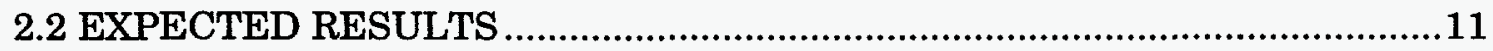

2.3 PROJECT BACKGROUND AND RATIONALE ....................................11

2.4 PROJECT ORGANIZATION ...........................................................13

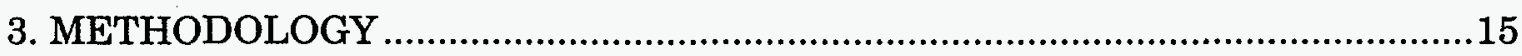

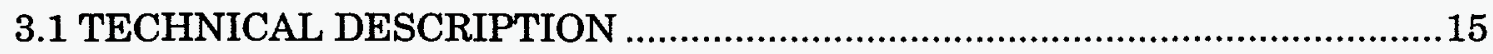

3.2 TECHNICAL APPROACH FOR PHASE 1 BENCH-SCALE TESTING.........19

3.2.1 Westinghouse STC Bench-Scale Testing of Inorganic Removal.................19

3.2.2 KAI Technologies Bench-Scale Test of Organic Processing........................19 


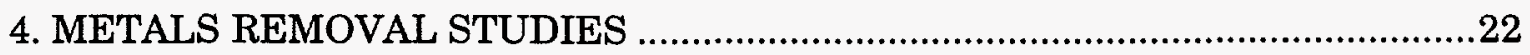

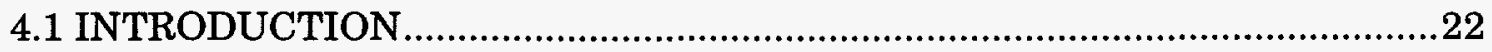

4.2 OBJECTIVES

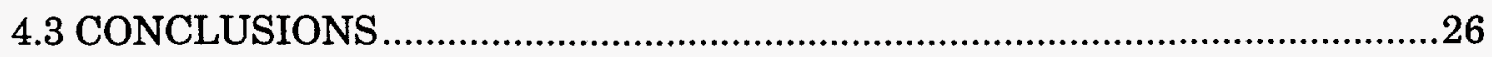

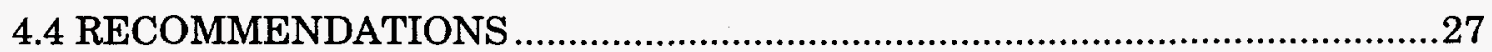

4.5 SELECTION OF ASBESTOS AND CHARACTERISTIC CONTAMI-

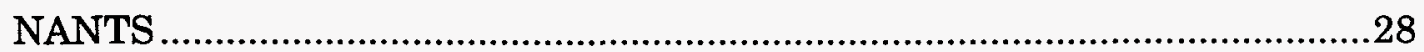

4.6 CHARACTERIZATION OF THE ABCOV SUSPENSION ............................. 31

4.6.1 Receipt and Handling of the Asbestos Suspension ............................... 31

$4.6 .2 \mathrm{pH}$ Measurements and Neutralization Potential....................................33

4.6.3 Measurement of Gross Suspension Density and Ultimate Particle

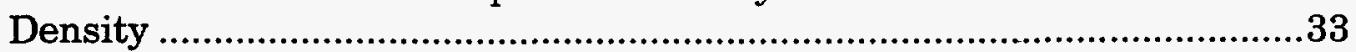

4.6.4 Clarification of the Converted-Asbestos Suspension ....................................35

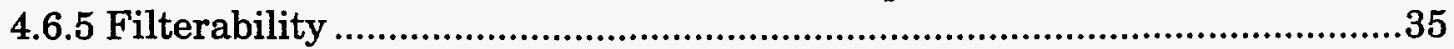

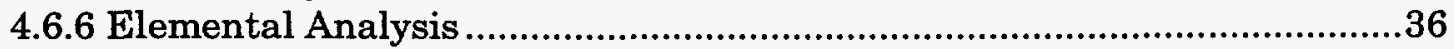

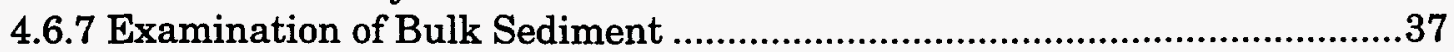

4.6.8 Determination of Particle Size .............................................................38

4.6.9 Total Suspended and Dissolved Solids ..........................................................38

4.7 ION EXCHANGE STUDIES USING ABCOV SUSPENSION ……...................39

4.7.1 Preparation of Doped Suspensions and Solutions............................................39

4.7.2 Partitioning of Contaminants in Doped ABCOV Suspensions ....................40

4.7.3 Contaminant Partitioning in Doped Solutions ............................................43

4.7.4 Ion Exchange Test Procedures ...................................................................43

4.7.5 Ion Exchange Resins Used.....................................................................44

4.7.6 Planned Ion Exchange Test Results.....................................................45

4.7.7 Ion Exchange Screening in Simpler Solutions ............................................48

4.8 ION EXCHANGE TESTING OF REVISED CONCEPT IN ALKALINE

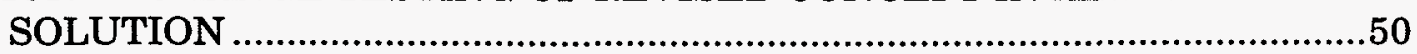

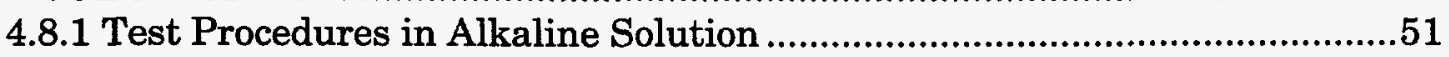

4.8.2 Ion Exchange Tests in Alkaline Solution ...................................................51

4.8.3 Resin Loading Tests with Urynal Nitrate Tests .........................................53

4.8.4 Regeneration of the Ion Exchange Resin ...............................................54

4.9 DISCUSSION OF ION EXCHANGE STUDIES AND CHARACTERIZATION 
4.9.1 Characterization of the Asbestos-Conversion Suspension.......................55

4.9.2 Ion Exchange from the Asbestos-Conversion Acidic Solutions.................56

4.9.3 Ion Exchange in Alkaline Solution .....................................................5

4.10 PROPOSED PROCESS FOR MIXED WASTE REMEDIATION .................57

5. KAI BENCH-SCALE ORGANIC PROCESSING TESTS...............................62

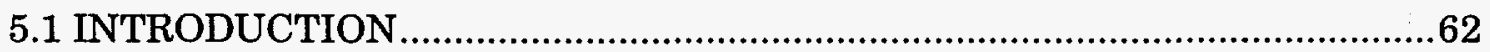

5.2 DIELECTRIC AND THERMAL PROPERTIES OF THE SILICA SUS-

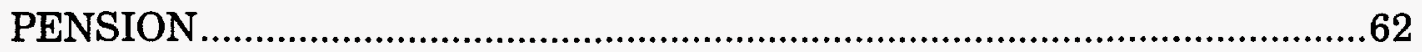

5.3 LABORATORY RF HEATING TESTS...................................................64

5.4 DETAILED DESCRIPTION OF BENCH-SCALE TESTS ..........................67

5.5 DISCUSSION OF ANALYTICAL DATA ............................................. 71

5.6 THEORETICAL MODELING OF THE LABORATORY RF HEATING

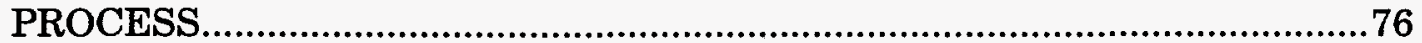

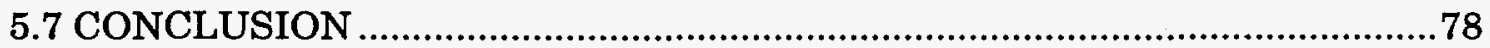

5.8 COLD PLASMA DECOMPOSITION OF PCB SURROGATE FEASIBIL-

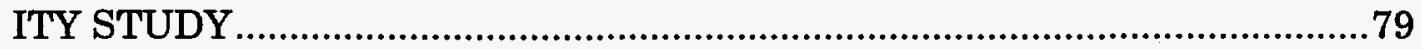

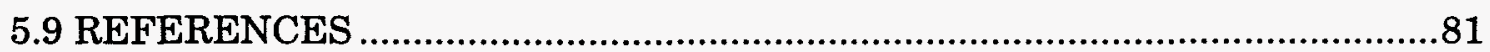

6. TREATMENT OF ASBESTOS USING THE ABCOV METHOD ........................82

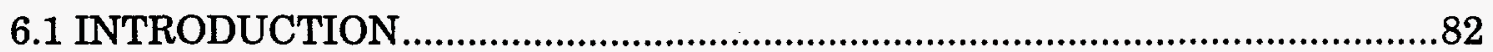

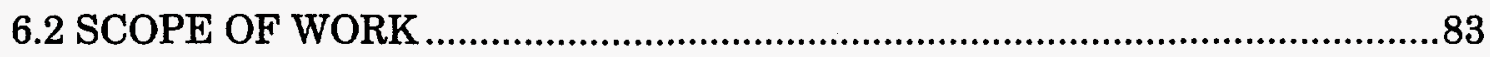

6.3 MATERIALS AND METHODS ......................................................... 83

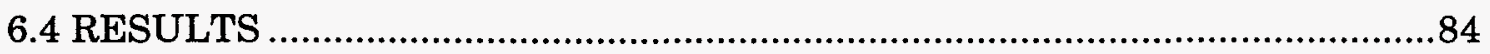

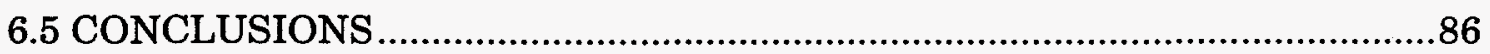

7. INTERACTION WITH POTENTIAL USERS ................................................87

8. PHASE 2 TECHNICAL APPROACH .................................................... 88 


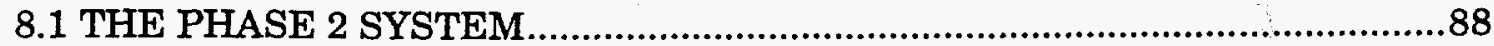

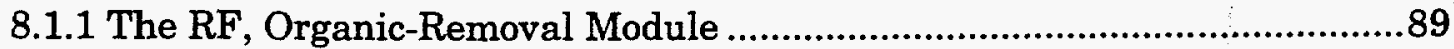

8.1.2 The Uranium-Dissolution-and-Removal Module ...........................................89

APPENDIX A - KAI BENCH-SCALE TEST ANALYTICAL DATA

APPENDIX B - ASSAIGAI ANALYTICAL LABORATORY DATA ON COLD PLASMA PRODUCTS.

APPENDIX C - OHIO DSI ASBESTOS DATA 


\section{LIST OF FIGURES}

Figure 1.1 - Mixed Waste Processing System for Contaminated Asbestos............8

Figure 2.1 - Project Organization Chart. ...............................................13

Figure 4.1 - Original Concept of the Mixed Waste Process .................................22

Figure 4.2 - Updated Concept of the Mixed Waste Process .................................24

Figure 4.3 - The splitter provided representative aliquots of suspension ..............32

Figure 4.4 - Suspension was pumped from the transport carboy through a liq-

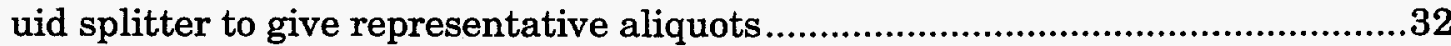

Figure 4.5 - Variation of $\mathrm{pH}$ with Addition of $\mathrm{NaOH}$ in $\mathrm{ABCOV}$ Suspension ........34

Figure 4.6 - The level of the ABCOV-solids sludge settled very slowly..................35

Figure 4.7 - Distribution of contaminants in the ion exchange processing with

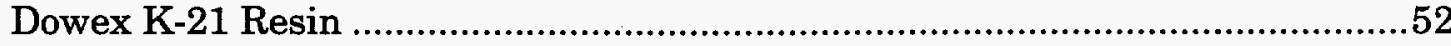

Figure 4.8 - Process Flow Diagram for Mixed Waste Remediation of Asbestos.....58

Figure 5.1 - Pure ABCOV-C Conductivity Measurements. ................................63

Figure 5.2 - Loss Tangent (Conductivity) Measurement of Pure ABCOV-C.........65

Figure 5.3 - Loss Tangent (Conductivity) Measurement of ABCOV Solution with Converted ACM (Silica) in Suspension ..................................................65

Figure 5.4 - Loss Tangent (Conductivity) Measurement of ABCOV Solution with Converted ACM (Silica) in Suspension and 1000 ppmV TCE Added ..........66

Figure 5.5 - Loss Tangent (Conductivity) Measurement of ABCOV Solution with Converted ACM (Silica) Not in Suspension (Settled) .............................66

Figure 5.6 - RF Retort with ABCOV Solution Sample Holder. .............................68

Figure 5.7 - Test 1: RF Power and Sample Temperature Data...........................69

Figure 5.8 - Test 1: VSWR of the Laboratory RF Heating System ....................69

Figure 5.9 - Test 3: VSWR of Laboratory RF Heating System...........................72

Figure 5.10 - Test 3: Sample Temperature and RF Power Data.........................72

Figure 5.11 - Test 4: Sample Temperature and RF Power Data...........................73

Figure 5.12 - Test 3: Concentration of PCE (Part 1).......................................74

Figure 5.13 - Test 3: PCE Concentration (part 2) ......................................... 74

Figure 5.14 - Test 4: PCE Concentration. ................................................ 75

Figure 5.15 - Concentration of PCE in Silica Suspension Samples (based on analytical measurements performed by American Environmental Laboratories).

Figure 5.16 - PCE Reduction in PCE Spiked ABCOV Solution.........................76

Figure 5.17 - Electric Field Distribution in KAI Sample Holder Calculated by NEC-4. 


\section{LIST OF TABLES}

Table 4.1 - Principal Contaminants Expected in Asbestos ................................30

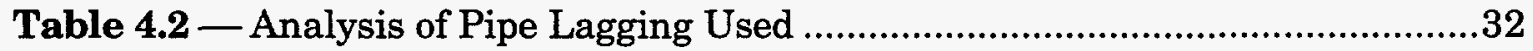

Table 4.3 - Elemental Analysis of the ABCOV Suspension ..............................36

Table 4.4 - Partitioning of Contaminants Between Solids and Liquid .................41

Table 6.1 - Results of the ABCOV-C Testing ...................................................84

Table 6.2 — Particle Size Estimate............................................................85 


\section{ABBREVIATIONS, ACRONYMS, AND TECHNICAL TERMS}

$\begin{array}{ll}\text { ACM } & \text { Asbestos-containing materials } \\ \text { DCP } & \text { Direct-current plasma } \\ \text { DSI } & \text { DSI Industries Consolidated, Inc. } \\ \text { ICAP } & \text { Inductively-coupled argon plasma } \\ \text { KAI } & \text { KAI Technologies, Inc. } \\ \text { PCB } & \text { Polychlorinated biphenyl } \\ \text { PCE } & \text { Perchloroethylene } \\ \text { WSTC } & \text { Westinghouse Science \& Technology Center } \\ \text { Supernate } & \text { The clear liquid separated from a suspension of solids. } \\ \text { RF } & \text { Radio Frequency }\end{array}$




\section{EXECUTIVE SUMMARY}

DOE's Morgantown Energy Technology Center (METC) supporting the Environmental Restoration and Waste Management (EM) Office of Technology Development provided the Phase 1 Contract Research support described herein. The overall objective of this project is to develop and demonstrate a cost-effective technology that converts contaminated asbestos to a form suitable for disposal in a sanitary landfill, or to a form which stabilizes radioactive inorganics and heavy metals in a solidified silica suspension for disposal as a low-level waste. The Phase 1 program of the Electromagnetic Mixed Waste Processing Systems for Asbestos Decontamination consisted of laboratory tests to establish the technical feasibility of each of the following process steps, i.e., ABCOV method for asbestos decomposition, organic removal using radio frequency technologies, and removal of radionuclides and heavy metals designated as hazardous by RCRA using ion exchange or physical separation. Ohio DSI Corporation provided the ABCOV method; KAI Technologies provided the radio frequency technology, technical direction, and contract project management; and WSTC provided ion exchange/physical separation testing and the overall process design and integration. The technical team of KAI, Ohio DSI, and WSTC, in close cooperation provided the three separate technology applications to achieve the Phase 1 objective.

\subsection{ASBESTOS DECOMPOSITION}

The ABCOV process transforms asbestos to a non-asbestos form of material. The basis for the transformation is the conversion of the silica portion of the structure in the asbestos fibers to fluorosilicate or similar structures through reaction with fluoride. The resulting fluorinated species is not regulated as hazardous. It is 
not known to exhibit the carcinogenic traits attributed to asbestos. Basis of the DSI technology is the reaction of fibrous solid asbestos with fluoride in a liquid, acidic medium. DSI has four patents covering aspects of asbestos destruction process and markets the asbestos conversion (ABCOV) chemicals associated with the process.

The ABCOV method was applied to crysotile and amosite-type asbestos material (pipe lagging) provided by Griffiss AFB. Thirty-three conversion runs were performed by treating the asbestos with ABCOV-C solution, a weak, organic acid. In all thirty-three cases, the fibers were converted to a non-asbestos form of material in 45 minutes. The purpose of the runs was to demonstrate and generate treated material for experimental operations by KAI Technologies, Inc. (KAI) and Westinghouse Science \& Technology Center (STC). Ohio DSI was tasked to initially analyze the ACM, wet it using ABCOV-T, and treat it using ABCOV-C. The resulting solutions and solids were then provided to KAI and Westinghouse. Ohio DSI was tasked to provide each contractor with 30 liters of solution resulting from the treatment of 4.1 kilograms of asbestos.

Specifically, Ohio DSI performed the following activities:

1. Confirmed asbestos content of selected test material (Griffiss AFB supplied).

2. Performed asbestos destruction runs (a low-temperature process) using ABCOV-T and ABCOV-C.

3. Sent converted ACM and ABCOV-C to Westinghouse and KAI.

4. Provided a Final Report to KAI.

\subsection{REMOVAL OF HEAVY METALS AND RADIONUCLIDES}

For the Westinghouse involvement in Phase 1, Bench-Scale Testing of Inorganic-Extraction Processing, the objective is to establish the technical feasibility of inorganic radionuclide and heavy metal removal at the laboratory scale using ion exchange and physical separation. 
The technical feasibility of inorganic radionuclide and heavy metal removal was established in bench-scale experiments using ion exchange and physical separation. The starting material for the decontamination bench-scale tests was an amorphous silica suspension prepared using the ABCOV process. The starting material contained organic and inorganic radionuclide contaminants. A total of four gallons of the $\mathrm{ABCOV}$ suspension was used to determine design and performance data for the ion exchange and physical separation processes.

The WSTC Phase 1 experimental work included the following elements:

- Specify the materials to be used in testing

- Specify the contaminants to be used in separation testing

- Handle and characterize the ABCOV suspension

- Dope the ABCOV suspension with contaminants

- Prepare stock solutions of the contaminants to be used, in their proper species. These are designated as lead, uranium, and thorium.

- Dope the suspension with concentrations of the dopants determined from FERMCO data

- Perform separation tests on the doped suspension

- Determine resin loading capacity

- Determine extent of resin regeneration

The Phase 1 investigation related to the removal of heavy metals and radionuclides from the decomposed asbestos solution consisted of three parts. The first part was an investigation of what contaminant concentrations and chemical species can be expected in asbestos at sites producing nuclear-bomb materials. The second part was the characterization of the suspension of converted asbestos provided by Ohio DSI. The third part was the study of ion exchange in the removal of contaminant metals from the suspension. 
Extensive discussions with staff members at FERMCO narrowed the range of probable contaminants to

$$
\begin{aligned}
& \text { uranyl nitrate, } \mathrm{UO}_{2}\left(\mathrm{NO}_{3}\right)_{2} 6 \mathrm{H}_{2} \mathrm{O} \\
& \text { ammonium diuranate, }\left(\mathrm{NH}_{4}\right)_{2} \mathrm{U}_{2} \mathrm{O}_{3} \\
& \text { lead oxide, } \mathrm{PbO} \\
& \text { uranium trioxide, } \mathrm{UO}_{3} \text {. }
\end{aligned}
$$

Concentrations of these contaminants are expected to be low, typically less than $500 \mathrm{ppmv}$ and ranging down to low- or zero-ppm values. Occasional hot spots may contain concentrations as high as $2000 \mathrm{ppmv}$ or $0.2 \%$. Other radionuclides and hazardous metals could be present, but are not expected owing to the process chemistry and radiochemistry.

Characterization of the ABCOV suspension provided useful data on its density, suspended solids content, dissolved solids content, $\mathrm{pH}$, particle size distribution, particle density, and nature of the solids. In general, the suspension is a mixture of extremely fine, slow-settling solids and an acidic solution saturated with one or more chemical species.

Ion exchange experiments included investigations of four contaminant compounds that are expected to be present in asbestos removed from DOE weapons complexes. These compounds were chemically contacted with ion exchange resins selected for effective removal of lead and uranium. Conclusions obtained from the ion exchange studies include:

- Ion exchange experiments completed in the absence of calcium, magnesium, and fluoride ions show the advantage of avoiding high concentrations of ions that compete for ion exchange removal through adsorption.

- The saturation concentrations of one or more solutes in the converted suspension may limit solubility of contaminant compounds.

- Calcium and magnesium solubilized by the asbestos-conversion process compete strongly for sites on the ion exchange resins. 
- $\quad$ Fluoride ions, present in the asbestos-conversion reagents compete for sites on anionic ion exchange resins, which reduce the effectiveness of the resin.

The original flow sheet for this process provided for separations of contaminant metals after the conversion of asbestos into amorphous solids. The results of studies completed in this first phase of work point to the advantage of wetting asbestos and dissolving contaminant metals prior to contact with the asbestosconversion reagents.

The technical approach for Phase 2 will be the effective ion exchange removal of hazardous metals and radionuclides as a first step in the overall process. This approach avoids the complications in chemistry that occurs by application of ion exchange in the presence of the asbestos-conversion reagents. A direct benefit of this approach is the reduction of process cost and system complexity. Phase 1 studies show variation of solubilities of the contaminant compounds in water and the acidic $A B C O V$ reagent. Metal contaminants will be separated first as particles, secondly from solution by ion exchange coupled with electrochemical regeneration. The decontaminated asbestos will only then be converted to a harmless suspension by the ABCOV chemistry.

\subsection{RADIO FREQUENCY DEVOLATILIZATION OF ORGANICS AND COLD PLASMA DESTRUCTION OF SURROGATE PCB}

The radio frequency devolatilization process involves the frequency of selective interaction of the organic contaminant molecules with radio frequency electric fields to produce desorption and mobilization of organics by rotation of their chemical bonds (dipole moments) and the ensuing production of heat energy. Organic molecules such as PCB have a radio frequency energy absorption spectrum that is determined by applying standard dielectric measurement techniques.

The objectives for the Phase 1 Bench-Scale Tests were: (1) to establish criteria for determining the "success" of the laboratory-scale tests of the electromagnetic organic processing system, (2) to determine the constitutive properties of the amor- 
phous silica suspension, (3) to generate laboratory-scale test data for later comparison to the "success" criteria, and (4) to produce theoretical electromagnetic heating profile data for comparison to test results. Criteria for determining the overall success of the bench-scale tests were based on:

- $\quad$ Electromagnetic energy requirements (kwh per kg of ACM)

- Required heating rate

- $90 \%$ or greater removal for the organic contaminant, trichlorethylene (TCE) and perchloroethylene (PCE)

- Optimum treatment temperature

- Residence time for devolatilization

Based on the "success" criteria established in the Test Plan, the objectives of the radio frequency devolatilization process were achieved. The dielectric constant and thermal properties of the ABCOV solution were essentially that of water. The conductivity or loss tangent related to the complex dielectric constant demonstrated that the ABCOV solution is extremely RF energy absorbtive. This result provides rapid $R F$ heating rates for the solution with very practical $R F$ power requirements for boiling organic contaminants.

The theoretical analysis performed demonstrated good correlation between the anticipated heating rates and electromagnetic energy requirements and measured values of both. The RF heating tests conducted on three different RF containers of ABCOV solution (Test 2, control and Tests 3 and 4) demonstrated an optimum temperature for organic removal from solution by RF volatilization near the organic contaminant boiling point. PCE was selected for testing after initial testing with TCE showed rapid devolatilization without $R F$ application. This was the result of its relatively high vapor pressure as compared to PCE. Closure levels in excess of $90 \%$ were achieved. The residence time for the 200 watt RF power level employed in Phase 1 was 4 to 6 hours, but this time can be easily reduced to about 30 minutes with practical RF power levels in the 1 to 5 kilowatt range. 
Finally, a PCB surrogate, cold RF plasma destruction test was conducted as an adjunct to Phase $1 \mathrm{RF}$ testing. Dichlorobenzene was the chosen surrogate based on the use of cold plasma discharge to fracture benzene ring bonds. Initial experimental results demonstrated that this method, which should prove to be cost effective (a $100^{\circ} \mathrm{C}$ temperature process using the same RF power supply as would be employed for $\mathrm{RF}$ devolatilization of organics) provided the initiation of the key reactions that would lead to the complete fracture of the benzene rings in the presence of oxygen. This method is recommended for employment in Phase 2 for contained, bench-scale destruction of organics.

\subsection{RECOMMENDED MIXED WASTE PROCESSING SYSTEM DESCRIPTION}

The recommended process for remediation of asbestos-containing materials containing hazardous and radioactive contaminants is shown in Figure 1.1. The process begins with receipt of asbestos-containing material or ACM, which is reduced to smaller than one-inch size and dewatered in P1 by pressing, spinning, heating, or air drying depending upon its form.

At K1, the dry ACM encounters radio frequency energy, tuned to the resonant frequency of contaminant organics, which provides for rapid devolatilization. Alternative frequencies may be employed for the volatilization and destruction of contaminants depending on the dielectric properties of the contaminant. The vaporized organics or organic-reaction products are destroyed and condensed at K2 and are sent to final disposal. Hazardous metals and radionuclides remain at this point.

The dry, organic-free ACM is transported to W2 where it is slurried into water, acid, or other carrier appropriate to the form of the ACM. The slurry will contain contaminant hazardous metals and radionuclides dissolved in the carrier liquid as well as insoluble particles of contaminants.

The operation at W3 removes solid particles of uranium compounds, which have a high para-magnetic susceptibility in oxygen-containing compounds using magnetic field gradient separation. 


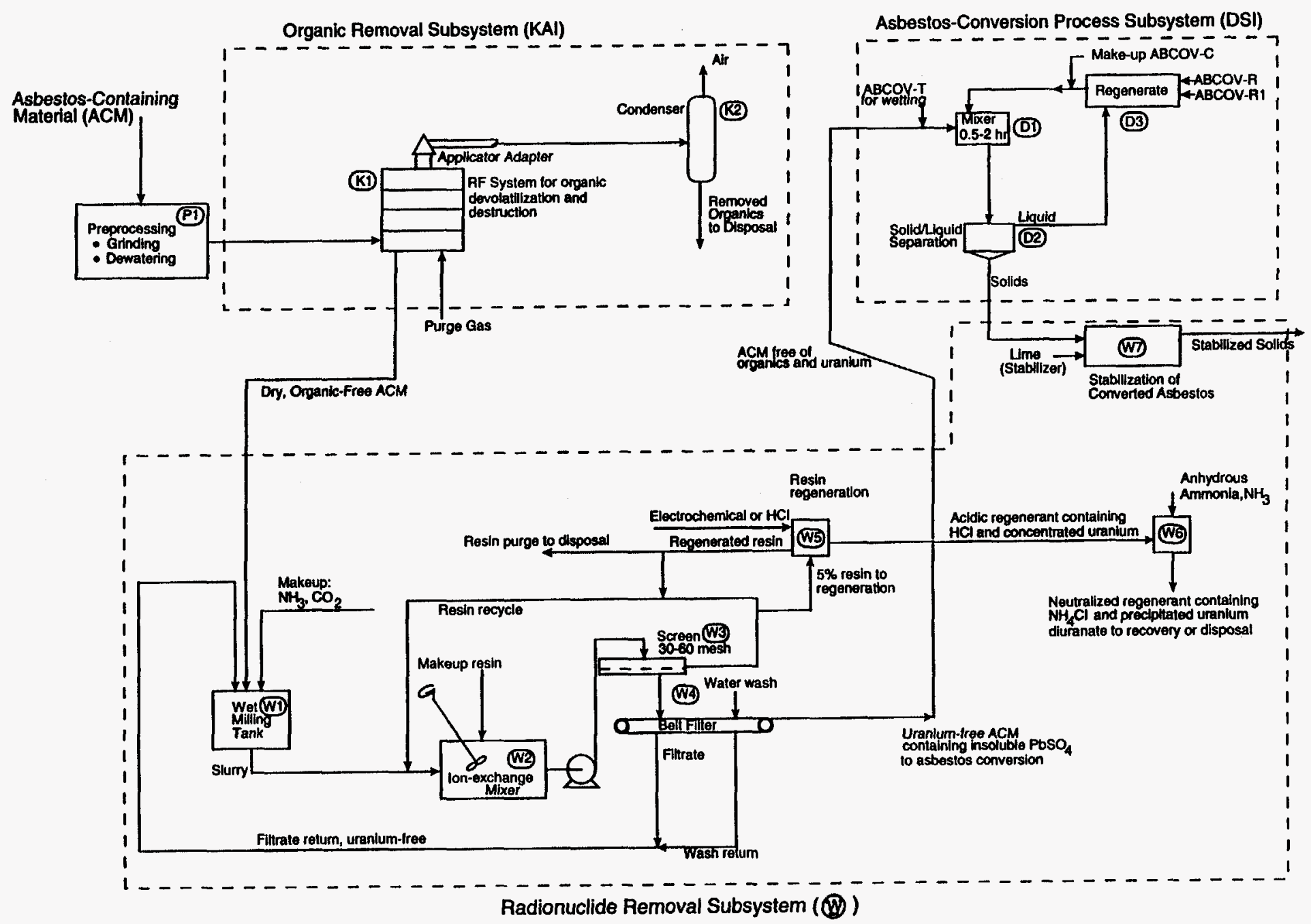

Figure 1.1 - Mixed Waste Processing System for Contaminated Asbestos. 
The solids-removal operation (W4) separates ACM solids and other solid contaminants from the liquid. The solids will contain the unconverted asbestos in ACM as well as contaminants insoluble because of intrinsic insolubility or because they are encapsulated as in the case of lead oxide entrapped in paint vehicle. The liquid is clarified prior to decontamination in a final filter (W5).

The liquids exiting W5 flow to the ion exchange/electrochemical operation at W6. Here, the soluble uranium and lead compounds are captured by the ion exchange resins, which are regenerated continuously by electrochemical processing.

Concentrated contaminants and regenerant chemicals collect and are concentrated prior to disposal at W7. Uncontaminated streams from W6 and W7 return to the Mixer/Scrubber vessel (W2) for re-use.

The moist ACM from W4 are conveyed to $\mathrm{D} 1$ where the asbestos conversion occurs under the chemical action of $\mathrm{ABCOV}$ reagents. The slurry exiting D1 flows to D2 where it separates into a clear recycle stream that flows to D3 for regeneration and re-use and a stream of dewatered solids.

The solids flow to $\mathrm{W} 1$ where stabilizers are added. The final product is a nonleaching solid that can be disposed safely. 


\section{INTRODUCTION}

\section{$2.1 \quad$ PROJECT GOALS}

The overall objective of this project is to develop and demonstrate a costeffective technology for converting contaminated asbestos to a form suitable for disposal in a sanitary landfill, or to a form which stabilizes inorganic radioactive and heavy metals in a solidified silica suspension for disposal as low-level waste.

The electromagnetic mixed waste processing system employs three patented technologies to convert DOE asbestos to a non-hazardous, radionuclide-free, sanitary waste: high-shear acid decomposition (ABCOV Method), metals separation, and radio frequency (RF) heating (KAI Electromagnetic Process). The asbestos is decomposed to an amorphous silica suspension using the high-shear acid process. Radionuclides and heavy metals are separated from this suspension by ion exchange and physical separation processes. The suspension is then heated with radio frequency energy to remove the organic volatiles. Finally, the amorphous silica is solidified with sodium silicate for disposal.

The objectives of Phase 1 were to establish the technical feasibility of asbestos decomposition, inorganic radionuclide and heavy metal removal, and organic devolatilization. The technical feasibility will involve separate bench-scale testing of:

1. Decomposition of asbestos to an amorphous silica suspension using the ABCOV technology described in U.S. Patent Number 5,041,277; performed by Ohio DSI Corporation in Columbus, $\mathrm{OH}$.

2. Removal of inorganic radionuclides and heavy metals designated as hazardous by the Resource Conservation and Recovery Act (RCRA) using ion exchange and physical separation processes; performed by WSTC in Pittsburgh, PA. 
3. Devolatilization of organics using RF-based technology described in U.S. Patent No. 5,065,819; performed by KAI Technologies, Inc. in Woburn, MA.

\subsection{EXPECTED RESULTS}

Asbestos Decomposition: The ABCOV method is a proven technology which is routinely used in commercial applications to decompose asbestos-contaminated materials. Therefore, DSI do not expect any problems with the ABCOV processing of $A C M$, or the generation of specified amounts of $A B C O V$-processed samples.

Removal of Inorganic Radionuclides and Heavy Metals: A batch process will be employed to demonstrate the capability of this process or proof-of-concept using ion exchange and physical separation methods. Organic contaminants will not be present in the WSTC test sample, and this step will be accomplished without the application of radio frequency energy. At least $80 \%$ of inorganic radionuclide surrogates and selected RCRA heavy metals are expected to be removed from the ABCOV-decomposed asbestos material.

Devolatilization of Organics: KAI will apply radio frequency energy to its ABCOV suspension after spiking it with a typical organic solvent such as TCE. The dielectric properties of the ABCOV suspension with spiked TCE should allow the absorption of this energy to raise the temperature of the entire liquid suspension to the boiling point of TCE. The TCE will boil selectively and be dispersed as an offgas through a vent hood. At least $90 \%$ recovery of the spiked component of the suspension is anticipated. An adjunct experiment will be performed to demonstrate the cold plasma destruction of surrogate PCB.

\subsection{PROJECT BACKGROUND AND RATIONALE}

In developing the United States nuclear weapons complex, the Atomic Energy Commission used asbestos insulation as standard material. In addition to being considered environmentally hazardous by itself, the asbestos has been contami- 
nated over the years with hazardous materials (lubricants, oils, solvents, PCBs, lead, mercury, and other heavy metals), radioactive contaminants (U, Tc, $\mathrm{Ra}, \mathrm{Pu}$, Th, Sr, and other DOE activation, decay, and fission products), and potentially metallo-organic compounds (residual extraction complexes of low-enrichment uranium), all present in various combinations and distributions. Asbestos decontamination for $\mathrm{DOE}$, therefore, must address the following key issues:

- Asbestos must be converted for both sanitary disposal and effective decontamination. (High-shear, acid attack)

- Hazardous and radioactive materials must be removed and separated to prevent formation of mixed wastes. (RF heating + electrochemical)

- Hazardous and radioactive wastes must be stabilized for disposal according to the requirements of the EPA for the RCRA materials and of the NRC for Radionuclides. (Stabilization)

Key related issues for commercial asbestos field services are risk management and process economics. In this case, a multi-stage processing system must be developed to meet the DOE objectives. Because each unit operation included in the proposed process has already been demonstrated at large scale independently, commercial-scale costing and risks associated with these operations are well known. Therefore, the overall cost of the processing system can be bound with a high level of confidence at each stage of the proposed demonstration. Using such semicommercial technologies manages the financial risks and supports the economic projections required to guide the program development and reduce costs. Because the system is based on technologies that already have been applied successfully in the mining, oil, and metals-processing industries (e.g., acid attack, radio frequency heating, and electrochemical and extractive separations), commercialization risks are reduced and reliably increased. 


\subsection{PROJECT ORGANIZATION}

The performance of the Phase 1 project was conducted by the three Principal Investigators overseeing the three processes included in the mixed waste processing system (Figure 2.1). Each Principal Investigator wrote the detailed, step-by-step plans for accomplishing his part of the project and performed the appropriate tasks during Phase 1.

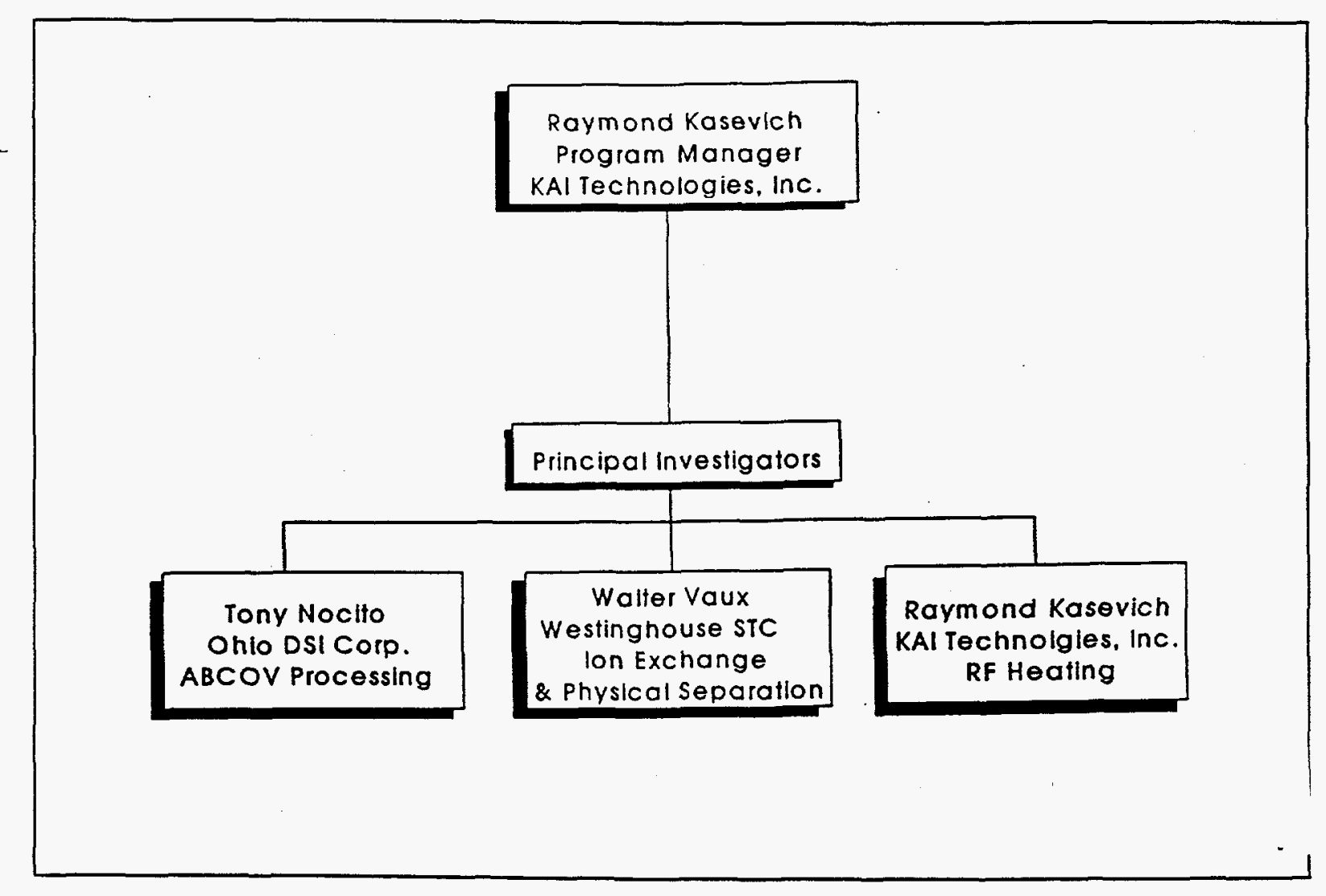

Figure 2.1 - Project Organization Chart.

The Test Plan for Phase 1 was reviewed and revised by the KAI Program Manager (R. Kasevich) to ensure smooth integration of the three processes. The Test Plan was then reviewed and approved by the COR (S. Bossart) to ensure that the approach met METC requirements and objectives. A final review and approval 
of the Test Plan was conducted by all key participants during the Kickoff meeting at METC in September, 1994. 


\section{METHODOLOGY}

\subsection{TECHNICAL DESCRIPTION}

The electromagnetic mixed waste processing system employs three patented technologies to convert DOE asbestos to a non-hazardous, radionuclide-free, sanitary waste; (1) high-shear chemical decomposition (ABCOV Method), (2) radio frequency heating (KAI Electromagnetic Process) and (3) ion exchange and physical/ chemical separation. The asbestos is decomposed to an amorphous silica suspension using the ABCOV Method of asbestos abatement and conversion to a non-toxic material. The silica suspension is heated with radio frequency energy to remove the organic volatiles and destroy the toxic organic chemicals. If necessary, the contaminated asbestos may be heated to remove and destroy organics before the ABCOV Method is applied. Radionuclides and heavy metals are separated from this suspension by an electrochemical process and physical separation including the application of magnetic field gradient technology if necessary. Finally, the amorphous silica is solidified with sodium silicate for disposal.

The ABCOV Method is a non-burning, simple and economical, chemical and mixing treatment of friable asbestos-containing material (ACM) that renders it harmless in a period of two hours or less. The ABCOV Method was developed after years of extensive research at Battelle Laboratories and Georgia Institute of Technology. It uses several chemical formulations to effectively improve the removal of asbestos-containing materials (ACM) and chemically convert asbestos into a nonhazardous substance. It offers the following advantages over conventional removal and disposal methods: 
- Removal time is reduced by applying the formulation ABCOV-T directly to the ACM, achieving improved wetting and initiating the conversion process. Some studies have documented removal times to be reduced by as much as $40 \%$, allowing for labor savings. In addition, after removal of ACM, ABCOV$\mathrm{T}$ can be used to clean substrates of any remaining fibers, eliminating the need for scrubbing with wire brushes.

- Depending on the type of filler material in the ACM, the volume of waste may be reduced by as much as $80 \%$. The removed ACM is immersed in a vat containing formulation ABCOV-C. After 30 or more minutes of agitation using a high-speed dispersion mixer, the mixture may be analyzed for the presence of asbestos fibers. Several previous demonstrations of the process by major utilities and federal institutions have confirmed conversion into a non-ACM substance.

- Since a hazardous substance no longer exists, it becomes unnecessary to transport the remaining material to an ACM-permitted landfill.

Thermal processing is the most effective approach for removing organics from the mixed waste matrix. As thermal processing candidates, both direct incineration and vitrification processing would destroy any organics present in the asbestos, and, in particular, vitrification can result directly in a stable waste form for disposal. The $\mathrm{KAI}$ radio frequency ( $\mathrm{RF}$ ) technology was selected over these processes for the following reasons:

- Incineration a) requires more complicated licensing for on-site, mobile operations; b) requires more expensive offgas processing/particulate collection system to contain airborne contaminants for an ALARA design for nuclear application (this includes other asbestos fibers and radionuclides); and c) may condition metals present in the asbestos decomposition residue to make radionuclide and heavy metal extraction more difficult.

- Vitrification would destroy organics condensing the asbestos and metals into a single vitrified waste form, but in so doing generates no potential waste minimization through release of a "sanitary" fraction in the form of the ABCOV product silica suspension.

By contrast, RF desorption meets both the needs of the DOE PRDA for a decontaminated, sanitary waste form, and the EPA requirements for pollution prevention and waste minimization in any waste treatment. 
Because RF dielectric heating "couples" directly with the waste at the molecular level, it does not rely on convective or conductive mechanisms for heat transfer. Such coupling is an intrinsic advantage of both radio frequency and microwave heating approaches (for materials with which they couple and which, otherwise, may resist conventional heating due to their insulating characteristics). As part of the RF process, an oxygen-driven cold plasma discharge is created to destroy organics such as PCB in the asbestos matrix.

Since asbestos is an insulation material, bulk-scale, thermal desorption processing by convective or conductive heating of the asbestos matrix will be extremely inefficient. Through the use of radio frequency coupling, the proposed process system penetrates the asbestos matrix effectively and results in rapid, even heating of organic molecules. Because RF coupling is a "non-invasive" heating process which injects energy directly into the substrate's atoms and molecules, RF-driven desorption has the following advantages.

- Risk of airborne emissions of organic and radioactive materials is reduced;

- An ALARA design is maintained, critical for all nuclear operations;

- Radioactivity exposure decreases through reduced maintenance and reduced material handling;

- Risk of airborne asbestos fibers is reduced.

Westinghouse technology for the various metals and radionuclide extractions includes a sequential multi-step approach.

- Removal of metals and metallic oxides by flotation or other gravimetric approaches;

- Filtration of the solids from the processing liquor;

- Ion exchange and/or electrochemical processing to process the liquids. 


\section{Waste Forms}

The potential waste forms to be stabilized after metals and organics removal from the asbestos include the following:

- A "fine fraction" consisting of metallic ions adsorbed onto the ABCOVgenerated silica suspension is a possible but unlikely form since we do not anticipate any chemical binding between the asbestos/silica and the contaminants. Further, we anticipate that the metallic contaminants will have reacted to metallic oxides prior to the asbestos removal and D\&D operations. The contaminants are compounds of $\mathrm{U}, \mathrm{Ra}$, Th, or others - all of which dissolve in the $\mathrm{ABCOV}$ reagent. As a result, these dissolved compounds should be separable by a solid/liquid separator.

- The "clean" or "sanitary" residue of the asbestos decomposition process is the major constituent. The residue is approximately one-tenth to one-eighth of the original asbestos volume.

- Any ion exchange or filtration media generated during the process is secondary waste.

Note that all of these streams are compatible with standard LLW radwaste stabilization media-grout, epoxies, polyesters, and/or silicates.

\section{Applications \& Benefits}

- Over $99 \%$ of asbestos converted for sanitary disposal and effective decontamination.

- Separation of radioactive and hazardous materials will prevent formation of mixed wastes.

- Destruction/separation of toxic organics.

- Stabilizes hazardous and radioactive wastes according to the RCRA and radionuclide material requirements of the EPA and NRC.

- Closed system process assures that public, worker, and environmental risks are minimized.

- Anticipated lower operating costs than comparable state-of-the-art alternatives such as plasma fired, thermal destruction combined with molten salt separation. 


\subsection{TECHNICAL APPROACH FOR PHASE 1 BENCH-SCALE TESTING}

\subsubsection{Westinghouse STC Bench-Scale Testing of Inorganic Removal}

For the Westinghouse involvement in Phase 1, Bench-Scale Testing of Inorganic-Extraction Processing, the objective was to establish the technical feasibility of inorganic radionuclide and heavy metal removal at the laboratory scale using ion exchange and physical separation.

The technical feasibility of inorganic radionuclide and heavy metal removal was established in bench-scale experiments using ion exchange and physical separation. The starting material for the decontamination bench-scale tests is an amorphous silica suspension prepared using the $\mathrm{ABCOV}$ process. The starting material contained organic, inorganic radionuclide, and heavy metal contaminants. A total of four gallons of the $\mathrm{ABCOV}$ suspension was used to determine design and performance data for the ion exchange and physical separation processes.

\subsubsection{KAI Technologies Bench-Scale Test of Organic Processing}

The objectives for the Phase 1 Bench-Scale Tests were: (1) to establish criteria for determining the "success" of the laboratory-scale tests of the electromagnetic organic processing system, (2) to determine the constitutive properties of the amorphous silica suspension, (3) to generate laboratory-scale test data for later comparison to the "success" criteria, and (4) to produce theoretical electromagnetic heating profile data for comparison to test results. Criteria for determining the overall success of the bench-scale tests will be based on:

- Electromagnetic energy requirements (kwh per $\mathrm{kg}$ of $\mathrm{ACM}$ )

- Required heating rate

- $90 \%$ or greater removal of the organic contaminant, TCE or PCE in the suspension samples 
- Optimum treatment temperature

- Residence time for devolatilization

The bench-scale processing of the volatile organic compounds (VOCs) involves laboratory RF heating experiments which will volatilize the VOCs in 1.8 liter samples of ABCOV suspension received from Ohio DSI Corporation. The laboratory tests will be conducted in a specially designed 55-gallon drum radio frequency (RF) retort. Prior to conducting these experiments the dielectric and thermal properties of the suspension will be measured. Volatiles will be removed in the laboratory heating experiments from samples of the suspension that have been "spiked" to a concentration of $100 \mathrm{ppmv}$ and $1000 \mathrm{ppmv}$ with the organic contaminant, TCE. Uncontaminated samples will also be RF processed for comparison. Theoretical thermal data generated by computer modeling will be compared to the experimental data.

\subsubsection{ABCOV Processing}

The objectives of the ABCOV Method were to convert approximately 4.1 kilograms of asbestos-containing material (ACM) for the following reasons:

1. To check the conversion of asbestos to a non-toxic material

2. To check the sludge particulate size upon completion of the ABCOV conversion process

3. To supply both KAI Technologies, Inc. (KAI) and Westinghouse Science \& Technology Center with approximately 30 liters of spent ABCOV-C and approximately 2.05 kilograms (by dry weight) of converted ACM so that KAI can prove that its $R F$ heating technology can successfully remove volatile organic compounds from the ABCOV sludge and Westinghouse can prove 
that its Electromagnetic and Ion Exchange technologies can successfully remove heavy metals from the $\mathrm{ABCOV}$ sludge.

The asbestos conversion was verified by using polarized light microscopy (PLM) which is the EPA-approved method to read ACM for the types and percentages of asbestos in ACM as well as other matrices. The PLM was done by a certified microscopist who has completed NIOSH 582, Sampling. 


\section{METALS REMOVAL STUDIES}

\subsection{INTRODUCTION}

The Westinghouse Science \& Technology Center (WSTC) Phase I LaboratoryScale Test Program was directed at developing the metals removal processing portion of the mixed waste decontamination system. Initially, the overall mixed waste processing system was envisioned to consist of the process elements depicted in Figure 4.1 below.

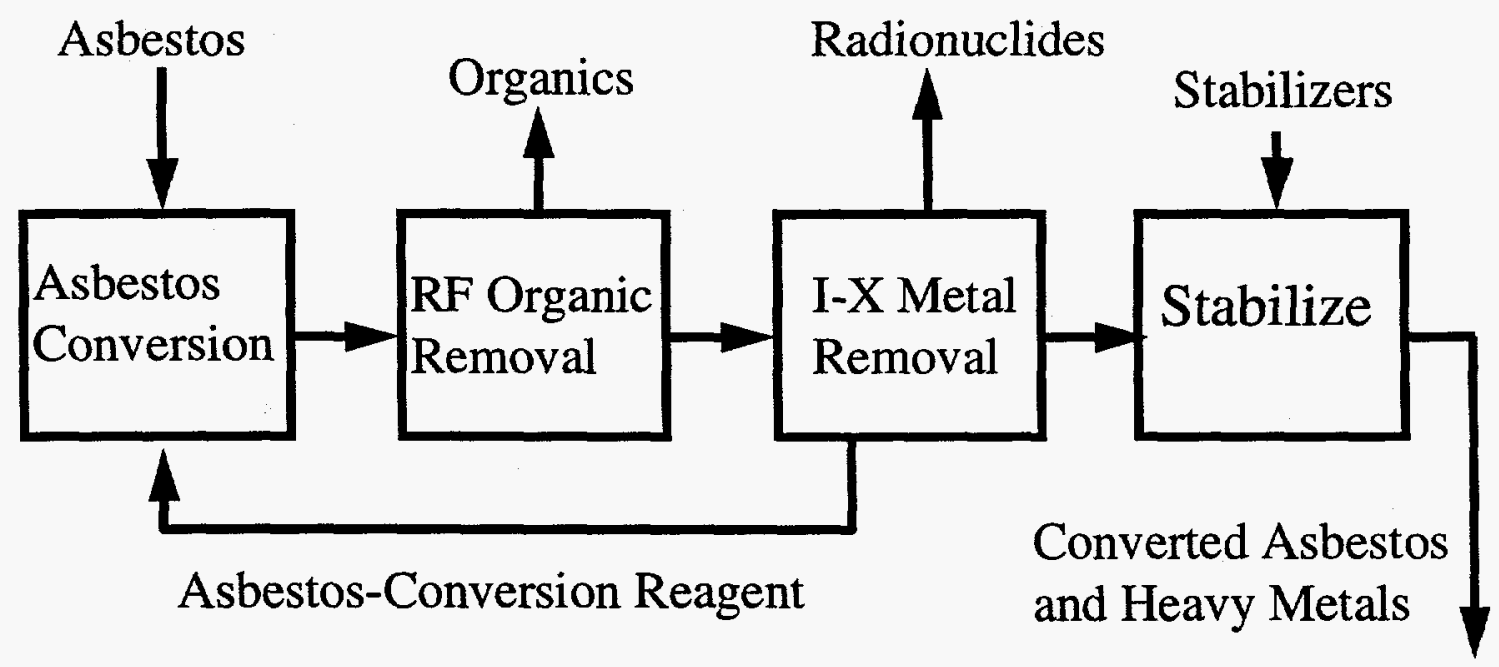

Figure 4.1 - Original Concept of the Mixed Waste Process.

In this original processing concept, asbestos is fed to the commerciallyavailable $\mathrm{ABCOV}$ process, designed to convert the asbestos into an amorphous solid using proprietary reagents. The contaminants in the asbestos suspension exiting 
the ABCOV process are expected to be distributed between the amorphous solids and the ABCOV liquid solutions. Assuming that the metals are primarily located in the liquid solution, the metals removal studies concentrated on developing a process to remove metals from the $\mathrm{ABCOV}$ solutions, allowing recycle of these solutions to the asbestos conversion process. Accordingly, WSTC's experimental program was directed at developing a metals removal process for expected metal contaminants in the $A B C O V$ suspension.

Ion exchange technology for metals removal has been applied extensively in the process industries, and particularly, in the uranium-mining industry. In order to demonstrate the feasibility of an ion exchange metals removal process, a test plan was developed that included characterization of the expected solution that would require ion exchange and performance screening tests to determine the feasibility of using ion exchange for metals removal.

In order to perform performance screening tests, WSTC needed to dope the asbestos suspension with target contaminants to provide test samples. Considerable effort was needed to define likely contaminants that should be used to dope the asbestos suspension. After doping the suspension, additional characterization work was performed to define the form and location of contaminants in the prepared materials.

Prior to performing the screening tests, success criteria for the tests were developed and approved by DOE to allow evaluation of the process feasibility. The success criteria for metal removal included $80 \%$ metals removal in one-stage ion exchange tests. The experiments performed on the ABCOV suspension did not meet the success criteria. There appeared to be no way that conventional processes could selectively ion exchange the desired contaminants from the ABCOV suspension. These test results, together with an overall process evaluation, lead WSTC to reconfigure the overall mixed waste processing system as shown in Figure 4.2 below. 


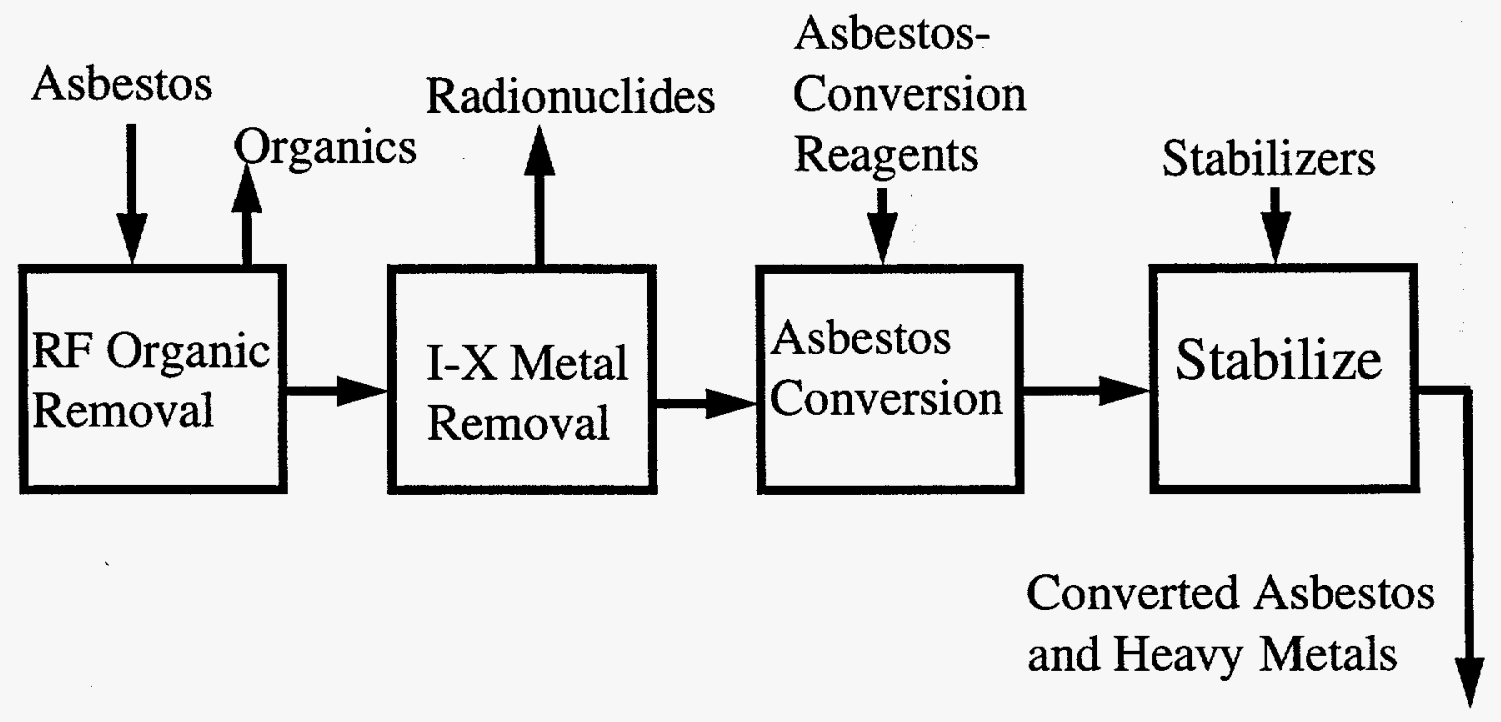

Figure 4.2 - Updated Concept of the Mixed Waste Process.

In this updated process configuration, the contaminated asbestos-containing material (ACM) is treated dry to remove organics with the KAI technology. The material is then washed to remove the metals in a system configured by WSTC that includes physical and chemical separation steps and ion exchange. Finally, the decontaminated solids are processed in the $\mathrm{ABCOV}$ system to convert the asbestos into amorphous solids.

WSTC performed screening tests using this process configuration. Metals removal from washed asbestos prior to ABCOV system introduction was successful. As will be described, these tests meet the success criteria and establish a basis to design an integrated, mixed waste processing system that will meet DOE's needs. This report section is organized into the following subsections:

- Section 4.2 describes the overall program objectives and the specific objectives for the WSTC Phase 1 work reported here.

- Section 4.3 summarizes the conclusions of the WSTC Phase 1 Program. 
- Section 4.4 provides Westinghouse STC recommendations.

- Section 4.5 describes the rational applied in selecting asbestos and contaminants for the test program.

- Section 4.6 describes the characterization performed on the ABCOV suspension.

- Section 4.7 describes the ion exchange metals removal testing performed in acidic solutions of the ABCOV suspension.

- Section 4.8 describes the ion exchange metals removal testing performed in alkaline solutions for the revised concept.

- Section 4.9 presents a summary discussion of the results.

- Section 4.10 describes the revised process developed for mixed waste remediation, and provides the process flow diagram with its material balance.

\subsection{OBJECTIVES}

The overall objective of this Mixed Waste Decontamination Program is to develop and demonstrate a cost-effective, integrated process for remediation of asbestos-containing material (ACM) that is contaminated with organics, heavy metals, and radioactive metals.

The objective of Westinghouse's Phase 1 Laboratory-Scale Program is to establish the technical feasibility of inorganic heavy metal and radionuclide removal at the laboratory scale using ion exchange and physical separation technologies.

The success criteria for these Phase 1 tests were to :

1. Demonstrate the feasibility of ion exchange to remove metals from the process stream by obtaining:

- $80 \%$ metals removal in beaker resin uptake tests

- $\quad 0.4$ equivalents $/ 1$ resin loading

2. Demonstrate the potential to regenerate the ion exchange resin by obtaining at least $50 \%$ regeneration of the resin in one cycle. 


\subsection{CONCLUSIONS}

The Westinghouse Phase 1 Laboratory-Scale Program established the technical feasibility of inorganic heavy metal and radionuclide removal at the laboratory scale using ion exchange and physical separation technologies. Test results lead WSTC to propose a revised integrated mixed waste processing system design for remediation of contaminated asbestos.

The success criteria for Phase 1 tests were met :

1. The feasibility of ion exchange to remove metals from the process stream was demonstrated by obtaining:

- $92 \%$ uranium removal in single-contact tests with a commercial ion exchange resin

- 0.6 equivalents/1 resin loading with uranium

- lead retention in the solid phase for stabilization, allowing separation of the radioactive materials from the hazardous contaminants.

2. The potential to regenerate the ion exchange resin was demonstrated by obtaining $52 \%$ regeneration of the resin in one-cycle screening tests.

Laboratory-scale tests on each processing operation have provided the basis to conceptually design a cost-effective, integrated process for remediation of asbestos-containing material (ACM) that is contaminated with organics, heavy metals, and radioactive metals. Process characteristics include:

Flexibility: Although the target remediation material for the system is asbestos, the process for inorganic removal has been applied to other types of contaminants. Concrete, demolition debris, and soil are material types that could also be remediated using the basic system elements being developed in this program.

Demonstrated Unit Operations: The overall process uses unit operations and technologies that have a proven track record for related remediation problems. For example, the metals separation process is based on Westinghouse soil washing experi- 
ence. Successful soil washing of a uranium-contaminated solution mining site at Bruni, Texas demonstrated the application of similar metals removal processes for soil remediation.

Economic Potential: The process offers significant economic advantage over hightemperature vitrification and mixed waste disposal options for the mixed waste asbestos containing materials.

Environmental Benefits: The process will be designed to have zero fugitive emissions. It will eliminate the need to consider incineration or other high-temperature processes that require stacks and gas cleaning systems. The converted asbestos is a nonhazardous material.

\subsection{RECOMMENDATIONS}

Although the basis for an integrated remediation system has been established in Phase 1, bench-scale development of the system is needed in order to develop and refine the design base for the processing system. Critical process development issues that need to be resolved in the Phase 2 Program include:

Separations of radioactive from nonradioactive species

Phase 1 tests indicate that separation of radioactive and hazardous contaminants is feasible. Success will, however, be dependent on the particular radionuclides and hazardous metals present in the contaminated asbestos. WSTC recommends that actually contaminated material be obtained for testing. If this is not feasible, the test program needs to include some testing with a range of contaminant species (testing this far has focused on three uranium compounds and one lead compound) in order to develop an understanding of process constraints.

Westinghouse experience in developing remediation systems has provided valuable information on developing surrogate materials for process testing. This experience has repeatedly shown, however, that real contaminated materials provide information needed for process designs that can not always evident in working 
with surrogate materials. WSTC, therefore, recommends that DOE provide actual contaminated materials for the Phase 2 test program.

Development of an optimal ion exchange and regeneration system

After testing a variety of resins in the presence of dissolved asbestos in acid solutions, the Phase 1 program demonstrated successful ion exchange with one resin used in alkaline conditions. Alternatives for ion exchange resins need to be considered in order to develop a versatile and economic system. Resin capacity needs to be established for expected contaminants. Regeneration options (acid stripping, electrochemical regeneration, and integrated electrochemical regeneration with removal) need to be technically and economically evaluated for the process under development.

Identification of solid/liquid separation issues in the metals removal system

Materials generated in the bench-scale test will provide a basis to design and select field testable components for the Phase 3 pilot tests. The selection of solids handling and solid/liquid separation systems will depend on the physical and chemical characteristics of the process solutions and the cleanup requirements for all process streams. Bench-scale testing will provide data to allow judicious selection of pilot equipment.

\section{Verification of $A B C O V$ process on washed asbestos}

Asbestos washed in the metals removal system needs to be tested in the commercial $\mathrm{ABCOV}$ system to verify its processability and the impact, if any, that the washing may have on the existing commercial asbestos-conversion process.

\subsection{SELECTION OF ASBESTOS AND CHARACTERISTIC CONTAMINANTS}

Asbestos-containing material (ACM) can be present in a number of chemical and processed forms which include asbestos bats, pipe lagging, transite, and asbestos tile. The starting material for this study could have included any of these as well as laboratory-grade asbestos available from chemical-supply vendors. The material 
chosen for this work was actual pipe lagging removed from a power-generation facility. This choice was made in order to:

- use an actual material to offer and uncover some of the problems associated with ACM fillers, and

- use a material widely present in weapons-production plants that are being remediated.

A principal decision in design of this test program was designating which contaminants would represent those found in asbestos in a weapons-production plant. Extensive discussions with staff at FERMCO in Fernald, Ohio provided narrative information on the contaminants and approximate concentrations. Discussions with the FERMCO staff did not identify any reports or survey results on metallic contaminants, speciation of these contaminants, or measured concentrations.

The results of lengthy discussions did, however, provide the following guidance for contaminant selection for the WSTC test program.

- Uranium is the principal contaminant.

- Uranium may be present in cationic or anionic forms such as ammonium diurinate, uranyl nitrate, or uranium trioxide.

- Other possible radionuclides present might be thorium, strontium, or barium, but they would be in minor amounts if present.

- Lead is expected in two possible forms: first is lead oxide from the paint used for coating pipe lagging; second is metallic lead scuffed onto transite from lead washers, bolts, and flashing. Discussions with FERMCO did not uncover quantitative data on the fraction of lead used in either of these applications, but suggested that the lead from lead paint predominates. 
- Both uranium and lead are expected to occur at concentrations averaging $500 \mathrm{ppm}^{*}(\mathrm{mg} / \mathrm{kg})$ with a probable range of 200 to $2000 \mathrm{ppm}$.

Table 4.1 summarizes findings on typical asbestos contaminants expected at FERMCO.

Table 4.1 - Principal Contaminants Expected in Asbestos

\begin{tabular}{|l|l|l|l|}
\hline $\begin{array}{l}\text { Contaminant } \\
\text { Metal }\end{array}$ & Species & Probability & Notes \\
\hline Uranium & $\mathrm{UO}_{3}$ & very probable & \\
\hline Uranium & $\mathrm{UO}_{2}-\left(\mathrm{NO}_{3}\right)_{2}$ & probable & \\
\hline Uranium & $\mathrm{UF}_{4}$ & probable & from reduction process \\
\hline Uranium & $\mathrm{UO}_{2}$ & probable & \\
\hline Uranium & $\left(\mathrm{NH}_{4}\right)_{2} \mathrm{U}_{2} \mathrm{O}_{3}$ & probable & ammonium diurinate \\
\hline Uranium & $\mathrm{Ca}_{-} \mathrm{U}_{2} \mathrm{O}_{7}$ & probable & \\
\hline Uranium & $\mathrm{Na}_{2} \mathrm{U}_{2} \mathrm{O}_{7}$ & probable & \\
\hline Uranium & $\mathrm{U}$ & improbable & \\
\hline Uranium & $\mathrm{UF}_{6}$ & very improbable & UF is a gas \\
\hline Uranium & $\mathrm{UO}_{2}-\mathrm{F}_{2}$ & improbable & uranyl fluoride \\
\hline Lead & $\mathrm{PbO}$ & most probable & $\begin{array}{l}\text { Paint. Concentrations } \\
\text { measured at avg of } 600 \\
\text { ppm, 200 to 1800 ppm }\end{array}$ \\
\hline Lead & metal & probable & metal fittings on transite \\
\hline Thorium & oxide & improbable & encountered rarely \\
\hline Thorium & oxide & improbable & encountered rarely \\
\hline
\end{tabular}

The contaminant species chosen for study are uranyl nitrate $\mathrm{UO}_{2}\left(\mathrm{NO}_{3}\right)_{2} 6 \mathrm{H}_{2} \mathrm{O}$, ammonium diuranate, $\left(\mathrm{NH}_{4}\right)_{2} \mathrm{U}_{2} \mathrm{O}_{3}$, uranium trioxide $\mathrm{UO}_{3}$, and lead oxide $\mathrm{PbO}$. These are the actual species expected to occur in the reactor areas. Choosing these

* All ppm values are on a weight basis, that is $\mathrm{mg} / \mathrm{kg}$, unless otherwise identified in the text. 
compounds provides uranium in both the cationic and anionic forms, and includes the hazardous metal, lead, in its most expected form.

\subsection{CHARACTERIZATION OF THE ABCOV SUSPENSION}

The metals removal process envisioned will include a variety of physical separation and chemical separation steps. The primary chemical separation step planned was ion exchange. In order to develop an integrated, metals removal process the suspension characteristics were needed. The initial characterization tests were, therefore, conducted on the original $A B C O V$ suspension material before it was doped with contaminant species.

\subsubsection{Receipt and Handling of the Asbestos Suspension}

Converted asbestos suspension, prepared for DSI by a contract laboratory, was characterized at WSTC to determine properties relevant to development of a metals removal process. In the following sections, the receipt and splitting of the suspension are described and each of the characterization tests is detailed.

The Westinghouse Science \& Technology Center (WSTC) received the converted-asbestos suspension from DSI Industries, Consolidated on October 11, 1994." The suspension was contained in a 15-gallon Nalgene ${ }^{\mathrm{TM}}$ carboy, closed with a screw cap. The container was undamaged upon receipt. The suspension had been prepared from asbestos with the composition given in Table 4.2. The suspension received at WSTC on October 11, 1994 contained a large fraction of non-asbestos solids.

\footnotetext{
- The material received from DSI Technologies is referred to in this report as "asbestos-conversion suspension" or "suspension", which was separated into two phases, referred to as "solids" and "solution."
} 
Table 4.2 - Analysis of Pipe Lagging Used

\begin{tabular}{lc} 
Material & Content, \% \\
\hline Chrysotile Asbestos & $35 \%$ \\
Amosite Asbestos & $30 \%$ \\
Total Asbestos & $65 \%$ \\
& \\
Cellulose & $5 \%$ \\
Other Components & $30 \%$
\end{tabular}

Analysis provided by Lawhon \& Associates, Inc. Date of Analysis: October 4, 1994

The WSTC staff first split the converted-asbestos suspension into representative aliquots using the liquid splitter shown in Figure 4.3. Suspension was pumped from the carboy through a small magnetic-gear pump, to the splitter which sent combined substreams from opposite quadrants into two separate containers. The operation of splitting the suspension is shown in the photograph, Figure 4.4. Containers were repeatedly split into smaller quantities, resulting in eight 1-gallon aliquots.

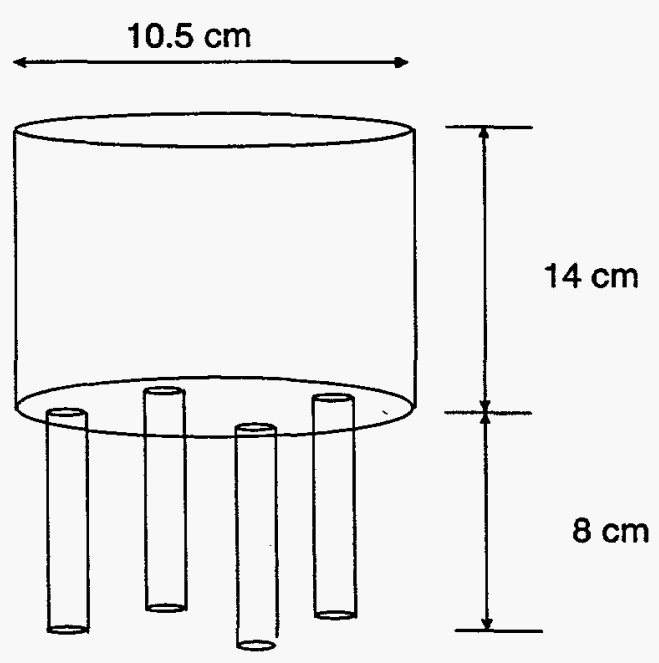

Figure 4.3 - The splitter provided representative aliquots of suspension.

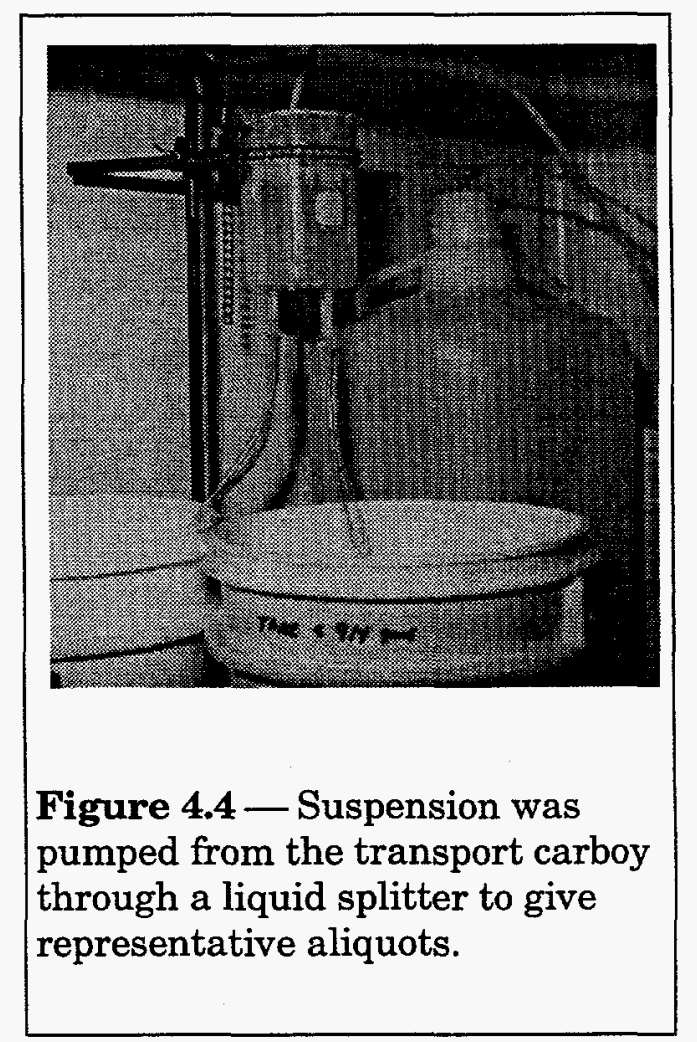


Aliquots of suspension were used for characterization tests. Characterization tests performed were $\mathrm{pH}$ measurements with an assessment of acid neutralization potential, density measurements, settling and filterability tests, elemental analysis, microscopic examination, particle size analysis, and total and dissolved solids analysis.

\subsection{2 $\mathrm{pH}$ Measurements and Neutralization Potential}

$\mathrm{A} \mathrm{pH}$ probe was rinsed and the meter was calibrated with a $\mathrm{pH}=4$ buffer. The $\mathrm{pH}$ of converted-asbestos suspension measured in each of the 1-gallon containers was 4.3. The converted-asbestos suspension is acidic. The rapid dissolution of a glass electrode and the notable etching of metal laboratory hoods indicate that it will tend to corrode equipment.

$\mathrm{pH}$ measurements were performed using electrodes and $\mathrm{pH}$ paper. While some variability exists in the various measurements, $\mathrm{pH}$ is concluded to be the center value of $4.0 \pm 0.5$. This range compares well with the value of $\mathrm{pH}=3.8$ to 4.5 as recounted by DSI in its commercial work.

In order to determine the potential to neutralize the suspension, an acid curve was prepared by observing the $\mathrm{pH}$ in sequential additions of $20 \%(0.00625 \mathrm{~N})$ aqueous $\mathrm{NaOH}$ into $100 \mathrm{ml}$ of the clear solution decanted from the asbestosconversion suspension.

The averaged results of 54 individual, replicated observations are shown in Figure 4.5. The slow response of $\mathrm{pH}$ to addition of caustic at the lower $\mathrm{pH}$ values indicates a buffering action that will tend to preserve or stabilize low $\mathrm{pH}$.

\subsubsection{Measurement of Gross Suspension Density and Ultimate Particle Density}

The net weight of an aliquot of suspension was measured. The volume of the same aliquot was measured with a cylindrical graduate. Duplicate measurements gave a suspension density of $1.153 \pm 0.001 \mathrm{~g} / \mathrm{cm} 3$. 


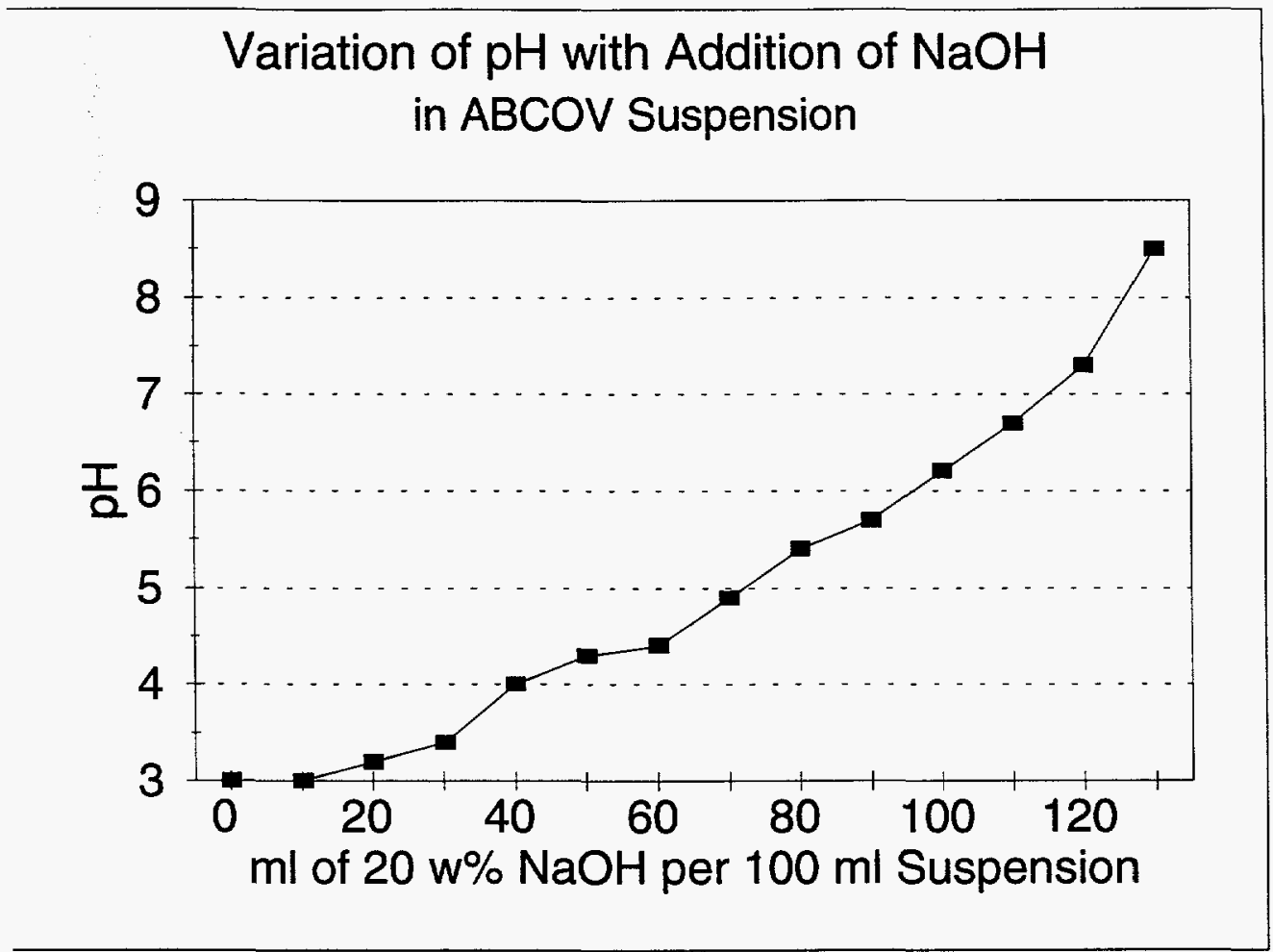

Figure 4.5 - Variation of $\mathrm{pH}$ with Addition of $\mathrm{NaOH}$ in $\mathrm{ABCOV}$ Suspension.

A sample of the converted-asbestos suspension was sent to Geotechnics, a soils engineering laboratory, for a pycnometer measurement of particle density and sedimentation test. The particle-size distribution could not be measured because of the high density of the converted-asbestos liquid, and the corrosivity of the liquid was incompatible with the metal lab equipment.

In order to circumvent this problem, a sample of converted-asbestos solids was washed by three repetitions of addition of water and isolating the solids by centrifugation. This washed material was characterized as having a particle density of $2.96 \mathrm{~g} / \mathrm{cc}$. This value agrees with the densities for various stones, which range from 2.16 to 3.14 , and it is almost identical with the density of crystal glass. 


\subsubsection{Clarification of the Converted-Asbestos Suspension}

The converted-asbestos suspension received for this study could not be clarified with conventional gravity clarification.

A representative aliquot of converted-asbestos suspension was shaken thoroughly and poured to the $817-\mathrm{ml}$ level in a cylindrical graduate. With the passage of time, the level of the sludge blanket changed as shown in the Figure 4.6.

Settling of Solids: ABCOV Suspension

Arithmetic Scales

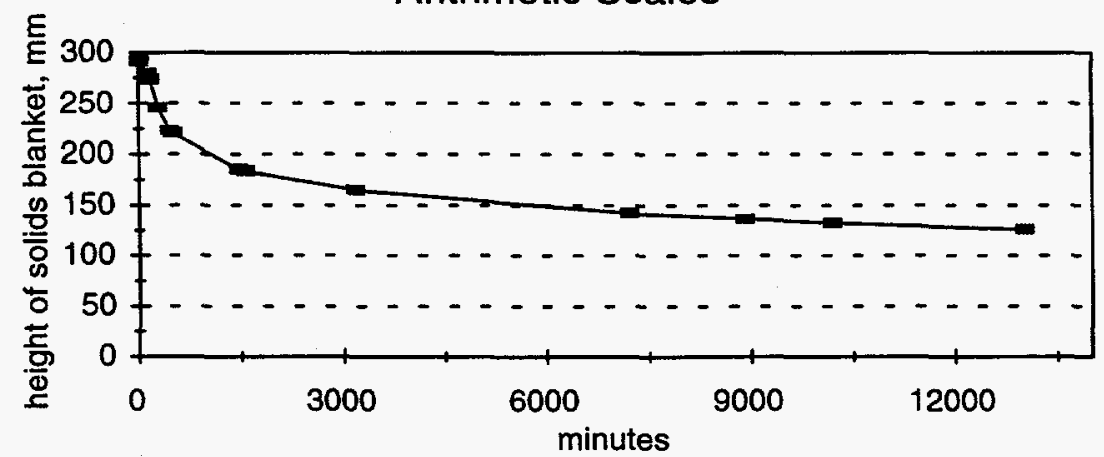

Figure 4.6 - The level of the ABCOV-solids sludge settled very slowly.

Clarification of this lot of suspension cannot be achieved in a conventional gravity clarifier. Any of three alternatives will aid settling. First is preparation of the converted-asbestos suspension with a less energetic mixer, which will reduce the formation of ultra-fine particles. Second, the addition of flocculants or coagulants will speed settling. Third, the use of a centrifuge has been demonstrated in the WSTC laboratories. The first method is preferable and has been demonstrated at DSI. Addition of coagulants is a possibility, but the presence of added chemicals, particularly organics, would befoul ion exchange resin.

\subsubsection{Filterability}

Vacuum filtration of the converted-asbestos solution was attempted to aid in collection of settleable solids. A first attempt to vacuum filter through a 0.45 micron 
filter paper on a buchner funnel allowed only one or two $\mathrm{ml}$ of clear liquid to pass. A second attempt through a "coarse" Whatman ${ }^{\mathrm{TM}}$ paper on a buchner funnel allowed about $10 \mathrm{ml}$ to pass before the filter paper was thoroughly blinded.

These attempts at filtration indicate that untreated converted-asbestos suspension is not practicably filterable, probably because of the exceptionally small size of particles in the suspension.

\subsubsection{Elemental Analysis}

Elemental analysis of supernatant liquid and solids obtained by emission spectroscopy are summarized in Table 4.3.

Table 4.3 - Elemental Analysis of the ABCOV Suspension

\begin{tabular}{lcc} 
Element & $\begin{array}{c}\text { Weight } \% \\
\text { Liquid }\end{array}$ & $\begin{array}{c}\text { Weight } \% \\
\text { Solids }\end{array}$ \\
\hline $\mathrm{Al}$ & 0.3 & 0.6 \\
$\mathrm{Ag}$ & $<0.02$ & $<0.001$ \\
$\mathrm{~B}$ & 0.3 & $<0.001$ \\
$\mathrm{Ba}$ & 0.2 & 0.01 \\
$\mathrm{Be}$ & $<0.01$ & $<0.001$ \\
$\mathrm{Bi}$ & $<0.01$ & $<0.003$ \\
$\mathrm{Ca}$ & 0.3 & $>1$ \\
$\mathrm{Cd}$ & $<0.1$ & $<0.02$ \\
$\mathrm{Co}$ & $<0.06$ & $<0.01$ \\
$\mathrm{Cr}$ & 0.07 & 0.3 \\
$\mathrm{Cu}$ & 0.02 & 0.01 \\
$\mathrm{Fe}$ & 1 & $>1$ \\
$\mathrm{Ga}$ & $<0.02$ & $<0.003$ \\
$\mathrm{Ge}$ & $<0.03$ & $<0.002$ \\
$\mathrm{~K}$ & 0.5 & 0.03 \\
$\mathrm{Li}$ & 0.02 & 0.001 \\
$\mathrm{Mg}$ & 0.7 & $>10$ \\
$\mathrm{Mn}$ & 0.2 & 0.1 \\
$\mathrm{Mo}$ & 0.2 & 0.003 \\
$\mathrm{Na}$ & $>1$ & 1 \\
$\mathrm{Nb}$ & $<0.1$ & $<0.02$ \\
$\mathrm{Ni}$ & 0.6 & 0.05 \\
$\mathrm{P}$ & $<0.3$ & $<0.06$ \\
$\mathrm{~Pb}$ & $<0.03$ & $<0.005$
\end{tabular}




$\begin{array}{llc}\mathrm{Sb} & <0.1 & <0.02 \\ \mathrm{Si} & 1 & 0.2 \\ \mathrm{Sn} & 3 & <0.003 \\ \mathrm{Sr} & 0.04 & 0.02 \\ \mathrm{Ti} & 0.7 & 0.01 \\ \mathrm{~V} & <0.01 & <0.004 \\ \mathrm{Zn} & <0.08 & <0.02 \\ \mathrm{Zr} & 0.03 & 0.04\end{array}$

\subsubsection{Examination of Bulk Sediment}

Visual and microscopic examination of the suspension was performed to identify processing options. The bulk sediment, observed after seven days of settling, is freely flowing with little evidence of stiffness, much like thick cream. The color is a grayish beige, similar to cooked oatmeal.

The purpose of this examination was to inspect the particles of the convertedasbestos suspension. From a well-shaken 1-gallon container of converted-asbestos suspension, $1 \mathrm{ml}$ of suspension was removed from three locations and combined in order to give a small, representative quantity of suspension. The locations chosen were:

- $1 \mathrm{~cm}$ from the surface of the suspension

- $1 \mathrm{~cm}$ from the bottom of the suspension

- mid-depth of the container.

Microscopic examination of a representative liquid suspension, placed in a petri dish, showed that:

- particles were widely spaced on the microscope slide

- particles are roughly spherical

- particles are dark amber, black, or clear

- particle diameter ranges between 2 and 30 microns

- there is no evidence of particle agglomeration. 


\subsubsection{Determination of Particle Size}

Particle size was first measured by microscopic examination, as described above, ranging to the limit of visual acuity, as 2 microns and larger. Quantitative measurements of particle size distribution were then made by ASTM method D 42263 which relates the density of the suspension at a hydrometer level to the particle size distribution. Results of the ASTM test give the following size distribution:

\begin{tabular}{cc}
$\begin{array}{c}\text { Particle size smaller } \\
\text { than (microns) }\end{array}$ & weight percent \\
\hline 75.0 & 100.0 \\
31.9 & 86.6 \\
20.2 & 86.6 \\
11.7 & 86.6 \\
5.8 & 86.6 \\
2.9 & 82.4 \\
1.2 & 78.3 \\
1.0 & 78.3
\end{tabular}

These values indicate that the particles of the converted-asbestos suspension are exceedingly small, observed as well in microscopic examination. At the end of 72 hours, the suspension undergoing ASTM settling still showed some cloudiness. The persistence of suspension accounts for the lack of information on particles smaller than 1.2 microns.

\subsubsection{Total Suspended and Dissolved Solids}

Converted-asbestos suspension was spun to total separation at 2,500 rpm in a centrifuge. The resultant solids were washed and rinsed twice with $-200 \mathrm{ml}$ of water. Drying of the wet solids at $91^{\circ} \mathrm{C}$ in an oven yielded the weight of dry solids. The suspended solids content of the converted-asbestos suspension measured at $4.84 \%$.

The clear solution obtained from converted-asbestos suspension was evaporated to dryness in an oven at $91^{\circ} \mathrm{C}$. The resulting dry crystals obtained were weighed. The dissolved solids content of the clear converted-asbestos solution is 
16.3\%. At the conclusion of drying the solids, the glass beaker was deeply etched, which led to an erroneously high result.

The experiment was repeated in a plastic beaker along with an empty plastic beaker to assure no error owing to change in tare weight. The results of measuring dissolved content in a plastic beaker was $5.1 \%$.

\subsection{ION EXCHANGE STUDIES USING ABCOV SUSPENSION}

The test plan was developed to perform ion exchange studies on doped ABCOV suspensions. The work planned for the ion exchange test program is documented in this section. First, the method of preparing the doped suspensions is described. The characteristics of the contaminants in the doped suspension is then reported. The results of initial ion exchange tests performed in doped ABCOV suspensions are then presented.

\subsubsection{Preparation of Doped Suspensions and Solutions}

\section{Doped Suspension Preparation}

Aliquots of the converted-asbestos suspension were each doped with the one of the four selected contaminants:

\begin{tabular}{ll} 
Name & Formula \\
\hline uranyl nitrate & $\mathrm{UO}_{2}\left(\mathrm{NO}_{3}\right)_{2} \cdot 6 \mathrm{H}_{2} \mathrm{O}$ \\
ammonium diuranate & $\left(\mathrm{NH}_{4}\right)_{2} \mathrm{U}_{2} \mathrm{O}_{3}$ (anhydrous) \\
lead oxide & $\mathrm{PbO}^{\text {anhydrous })}$ \\
uranium trioxide & $\mathrm{UO}_{3}$
\end{tabular}

The suspension was doped to target a metal concentration of $43 \mathrm{ppm}$, representing the amount expected in commercial processing of ACM that contains $500 \mathrm{ppm}$ of metal. Each beaker was covered and stirred for one hour with a magnetic stir bar.

In the actual commercial process, both $\mathrm{ACN}$ and contaminant compounds will be subjected to the converted-asbestos reagent at the same time. In these studies, the ACM alone was subjected to the converted-asbestos reagent, then the contami- 
nant compounds were added as fine powders to the mixture of reagent and converted asbestos. It is assumed that the contaminant compounds dissolve and distribute themselves in the mixture in the same way in both the commercial process and the laboratory procedure.

\section{Doped Solution Preparation}

In order to prepare samples for ion exchange tests, the ABCOV suspension was centrifuged to remove the solids from the liquid. Aliquots of the liquid solution were doped with each of the four reagents for testing. The solution preparation procedure was as follows:

1. Decant the clear supernate from asbestos-conversion suspension that had settled for a week or longer;

2. Using an analytical balance, weigh out the amount of contaminant required for a given concentration of metal ion in the supernate;

3. Stir and dissolve the contaminant compound into the supernate with a magnetic stirrer.

\subsubsection{Partitioning of Contaminants in Doped ABCOV Suspensions}

The doped suspensions were analyzed to determine how individual contaminants were present in the suspension. The suspensions were separated by centrifugation into solid and liquid forms to determine how the specified contaminants partitioned between the suspension phases. The resultant liquids and solids were weighed and assayed for concentration of contaminant metal. The recovered, dense solids were not washed. The results of experiments and chemical assays are presented in Table 4.4.

Since the solutions had many suspended fines, the separated liquid solutions were filtered through a $\mathbf{0 . 4 5}$ micron filter to determine if any of the liquid metals concentration was actually attributable to fines suspended in the solutions. 
Table 4.4 - Partitioning of Contaminants Between Solids and Liquid

\begin{tabular}{|c|c|c|c|c|c|c|c|c|c|c|}
\hline \multirow[b]{2}{*}{ Contaminant } & \multirow[b]{2}{*}{$\begin{array}{l}\text { Metal } \\
\text { Added, } \\
\text { mg }\end{array}$} & \multicolumn{3}{|c|}{ Solids } & \multicolumn{2}{|c|}{ Liquids } & \multirow[b]{2}{*}{$\begin{array}{l}\text { Total } \\
\text { Metal, mg } \\
\text { (solid + } \\
\text { solution) } \\
\end{array}$} & \multirow[b]{2}{*}{$\begin{array}{l}\text { \% } \\
\text { Metal } \\
\text { in Solid }\end{array}$} & \multirow[b]{2}{*}{$\begin{array}{l}\text { \% Metal } \\
\text { in Liq- } \\
\text { uid }\end{array}$} & \multirow[b]{2}{*}{$\begin{array}{l}\% \mathrm{Bal}- \\
\text { ance }\end{array}$} \\
\hline & & $\begin{array}{l}\text { metal } \\
\text { ppm }\end{array}$ & $\begin{array}{l}\text { solids, } \\
\mathrm{g}\end{array}$ & $\begin{array}{l}\text { metal, } \\
\text { mg } \\
\text { in solids }\end{array}$ & $\begin{array}{l}\text { metal, } \\
\text { mg } / 1 \text { so- } \\
\text { lution }\end{array}$ & $\begin{array}{l}\text { Metal, } \\
\text { mg in } \\
\text { solution }\end{array}$ & & & & \\
\hline ammonium uranate & 18.3 & 134 & 82.43 & 11.02 & 32.4 & 9.38 & 20.4 & 60.3 & 51.3 & 111.6 \\
\hline uranyl nitrate & 20.3 & 108 & 88 & 9.49 & 36.8 & 12.11 & 21.59 & 46.9 & 59.6 & 106.5 \\
\hline uranium trioxide & 22.5 & 114 & 95.3 & 10.85 & 35.2 & 12.62 & 23.47 & 48.2 & 56.0 & 104.2 \\
\hline lead oxide & 21.4 & 153 & 89.7 & 13.8 & 0.3 & 0.1 & 13.9 & 64.4 & 0.5 & 64.9 \\
\hline
\end{tabular}

1) \% Mass Balance, ( $g$ metal in solids $+g$ metal in liquid) $X 100 /$ total $g$ metal added 
The liquid concentration before and after filtering, shown below, indicates that a small amount of the uranium compounds may be suspended fines. Lead, however, was the primary component in filter cake from the lead solution.

\begin{tabular}{|l|l|l|}
\hline Contaminant & Concentration in Liquid, ppm \\
\hline & Before filtering & $\begin{array}{l}\text { After filtering } \\
\text { through 0.45 } \mu\end{array}$ \\
\hline ammonium uranate & $32.4 \mathrm{ppm} \mathrm{U}$ & $\begin{array}{l}\text { 28.2 ppm U } \\
\text { (All U on filter } \\
\text { paper dissolved } \\
\text { upon washing) }\end{array}$ \\
\hline uranyl nitrate & $36.8 \mathrm{ppm} \mathrm{U}$ & $29.8 \mathrm{ppm} \mathrm{U}$ \\
\hline uranium trioxide & $35.3 \mathrm{ppm} \mathrm{U}$ & $31.7 \mathrm{ppm} \mathrm{U}$ \\
\hline lead oxide & $0.3 \mathrm{ppm} \mathrm{Pb}$ & $\begin{array}{l}\text { Filter solids high } \\
\text { in Pb }\end{array}$ \\
\hline
\end{tabular}

These results indicate that in the presence of asbestos-conversion chemicals at low pH:

1. Uranium in the four compounds partitions almost equally between the solid and liquid phases. Two possibilities for the uranium being present in the solid phase are:

- The converted-asbestos solution, which is saturated in some compounds and contains 5.1 wt percent dissolved solids, will dissolve only a limited amount of these compounds.

- The contaminant metal or complexes adsorb on the amorphous asbestosconversion solids.

2. Lead, unlike uranium, is contained in the solid phase.

One would not expect lead to dissolve in the asbestos-conversion solution because of the insolubility of lead fluoride at $\mathrm{pH} 2$ to $\mathrm{pH} 4$ in the solution and the insolubility of lead silicates. The observed lead concentration of just $0.3 \mathrm{ppm}$ is not surprising. The small concentration was probably present as a sub-micron suspension of micro-particles. There are no apparent conditions that will favor the solubility of lead in the converted-asbestos suspension. This insolubility may serve as an 
advantage. It can allow separation of lead from the radionuclides and can allow sequestration (locking up, isolation) of the lead when the converted-asbestos solids are solidified for disposal so as to allow disposal of the solids as non-hazardous waste.

\subsubsection{Contaminant Partitioning in Doped Solutions}

Solution doped with contaminants showed an almost imperceptible cloudiness and evidence of deposits on the bottom of the polyethylene storage bottles. The solutions were filtered to determine if any contaminant species were precipitating into a solid form.

X-Ray fluorescence analysis of the residue collected identified a predominance of lead in the solids filtered from the solutions doped with lead. The presence of high values of calcium and magnesium indicate insolubles. It is likely that the fluoride present in the converted-asbestos solution reacted with calcium and magnesium and formed the insoluble $\mathrm{CaF}_{2}$ and $\mathrm{MgF}_{2}$. This further suggests the precipitation of lead as $\mathrm{PbF}_{2}$, which is insoluble in weak acid.

$\mathrm{X}$-Ray scans of residue collected in the residue from filtering the ammonium diuranate stock solution, however, showed that uranium is almost entirely absent, only iron was present in any appreciable amount.

\subsubsection{Ion Exchange Test Procedures}

Ion exchange studies were carried out as batch measurements. Column tests were not feasible because of the limited quantity of $A B C O V$ solution that was available. The test was performed on doped solutions of $A B C O V$ reagents as follows:

1. Prepare ion exchange resin

- hydrate the ion exchange resin in de-ionized by soaking it in water for one hour;

- condition the hydrated ion exchange resin by soaking it in the asbestosconversion supernate for one hour, then draining it of excess water and covering to prevent drying.

2. Contact the ion exchange resin with the contaminated stock solution

- weigh out pre-determined quantities of the contaminated stock solution and hydrated resin into a plastic beaker; 
- agitate the solution on a shaker table set to the same degree of agitation for all experiments;

- decant the clear supernate into a separate labeled beaker;

- assay the resin and treated solution for concentration of contaminant.

Assays of solutions were by direct-current plasma. Comparisons of results for paired samples from the Science \& Technology Center Laboratories and Core Laboratories in Casper, WY, using EPA Test Method 908.1, gave almost identical results.

\subsubsection{Ion Exchange Resins Used}

The ion exchange resins used in this work were those recommended by researchers at weapons-production plants and by vendors of ion exchange resins. Each of the resins selected are described below.

Diphonix manufactured by Eichrom Industries, Inc.

Diphonix, a diphosphonic acid resin, is designed for taking metals from acid solution. It is a cation exchange resin, effective for uranium and lead. While it is designed for cations, anionic uranium equilibrium will convert anionic uranium to cationic. Diphonix does not react with calcium or smaller sodium, ammonium so it will not waste its capacity on the abundant cations present in water. Zinc and copper, however, will react with the resin and should be minimized.

The moisture content of this lot received (Lot 070494) was 69.5\% as packaged. The expected capacity is 1.4 milliequivalent/dry gram based on the manufacturer's information; for uranium with valence of 2 , the capacity is 0.7 mmol/dry gram.

\section{Reilly Chemical Reillex}

This new resin, manufactured by Reilly Industries, is targeted for adsorption of uranyl ion from acidic solution in the range of $\mathrm{pH} 2$ to $\mathrm{pH} 4$. According to the manufacturer, it has performed well in the presence of ferric iron and high salt background.

\section{Rohm and Haas Amberlite IRA-900}

This resin is suited for uranium and thorium removal. Expected $U$ capacity is typically 0.8 equiv/liter.

Rohm and Haas Amberlite IRA-400

This resin is similar to IRA-900. It has a higher capacity for uranium, but the particles are not as sturdy. 
Rohm and Haas Amberlite IRC-718

IRC-718 is a cation exchange resin with a high affinity for heavy metal cations over alkali metals. It is well suited for barium and lead removal. Its capacity falls off below $\mathrm{pH} 4$.

\section{Allied Signal Hydrogel}

This is a very new product that has shown effective uptake of uranium in acidic solution.

Clay

Allied Signal performed some testing with a clay resin.

\subsubsection{Planned Ion Exchange Test Results}

A summary of ion exchange experiments performed in acidic and neutral solutions is presented in Table 4.5. Testing included the use of seven ion exchange resins in three types of solution chemistry, the ABCOV suspension liquid, water, and weak acid without solutes from the ABCOV process. Over 30 batch contact tests were performed at WSTC. In addition, Allied Signal attempted batch and column tests on proprietary resins. Successful metals uptake could not be achieved in acidic conditions. The difficulty of removing contaminants from the asbestosconversion solution is evident. In most cases, less than $50 \%$ metals removal could be achieved in the presence of the asbestos-conversion reagents. 
Table 4.5 - Summary of Ion Exchange Experiments in Acidic Conditions

\begin{tabular}{|c|c|c|c|c|c|c|}
\hline $\begin{array}{l}\text { Sample } \\
\text { Number }\end{array}$ & $\begin{array}{l}\text { Ion Exchange } \\
\text { Resin }\end{array}$ & Liquid Medium & $\begin{array}{l}\text { uranyl } \\
\text { nitrate }\end{array}$ & $\begin{array}{c}\text { ammonium } \\
\text { diuranate }\end{array}$ & $\begin{array}{l}\text { uranium } \\
\text { trioxide }\end{array}$ & $\begin{array}{l}\text { lead } \\
\text { oxide }\end{array}$ \\
\hline 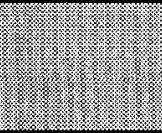 & \multicolumn{2}{|c|}{$\begin{array}{l}\text { Initial concentration of metal } \rightarrow \\
\text { in solution for experiments in asbestos- } \\
\text { conversion solution, } \mathrm{mg} / \mathrm{liter}\end{array}$} & 45 & 40 & 40 & 31 \\
\hline & & & \multicolumn{4}{|c|}{ Percent of metal removed from solution } \\
\hline $6-9$ & Hydrogel & ABCOV Solution & 25 & 32 & 0 & 74 \\
\hline 18 & Diphonix & ABCOV Solution & & & & 9 \\
\hline $36-39$ & Diphonix & ABCOV Solution & 11 & 3 & 0 & 0 \\
\hline $40-43$ & Reillex & ABCOV Solution & 4 & 4 & $<1$ & 0 \\
\hline $44-47$ & Amberlite-900 & ABCOV Solution & 0 & 1.4 & 0 & 2 \\
\hline $48-51$ & Amberlite- 400 & ABCOV Solution & 0 & 0 & 0 & 2 \\
\hline $54-57$ & Amberlite-IRC-718 & ABCOV Solution & 7 & 0 & 74 & 28 \\
\hline 61,62 & $\begin{array}{l}\text { Stoichiometric } \\
\text { Diphonix }\end{array}$ & Formic Acid & 83 & no dissolve & & \\
\hline 63 & $\begin{array}{l}\text { Stoichiometric } \\
\text { Diphonix }\end{array}$ & $\mathrm{ABCOV}+\mathrm{HNO} 3$ & & 0 & & \\
\hline 65 & Massive Diphonix & $\mathrm{ABCOV}+\mathrm{HNO} 3$ & & 34 & & \\
\hline 66 & Massive Diphonix & Water & & 26 & & \\
\hline 64 & $\begin{array}{l}\text { Stoichiometric. } \\
\text { Diphonix }\end{array}$ & ABCOV Solution & 0 & & & \\
\hline 66 & Massive Diphonix & ABCOV Solution & 26 & & & \\
\hline 70 & Amberlite-IRC-718 & Water & 74 & & & \\
\hline 71 & Control: no I-X & Formic Acid & 9 & & & \\
\hline 72 & Amberlite-IRC-718 & Formic Acid & 62 & & & \\
\hline
\end{tabular}

Ion exchange results in doped ABCOV solutions are presented in Table 4.6.

The following sections describe the results obtained for each resin.

Table 4.6 - Ion Exchange Results in ABCOV Solution

\begin{tabular}{|l|l|l|l|l|l|l|l|l|}
\hline & \multicolumn{7}{|c|}{ Metals Concentration in Solution after lon Exchange, ppm } & \\
\hline Resin $\rightarrow$ & $\begin{array}{l}\text { Original } \\
\text { Solution, } \\
\mathrm{ppm}\end{array}$ & Diphonix & Reillex & $\begin{array}{l}\text { Amberlite } \\
900\end{array}$ & $\begin{array}{l}\text { Amberlite } \\
400\end{array}$ & $\begin{array}{l}\text { Amberlite } \\
\text { IRC-718 }\end{array}$ & Hydrogel & Clay \\
\hline $\begin{array}{l}\text { uranyl ni- } \\
\text { trate }\end{array}$ & 45 & 46 & 44 & $46-50$ & 48 & 42 & 32 & 47 \\
\hline $\begin{array}{l}\text { ammonium } \\
\text { diuranate }\end{array}$ & 40 & $38-40$ & $38-40$ & 39 & 43.9 & 40 & 29 & 43 \\
\hline $\begin{array}{l}\text { uranium } \\
\text { trioxide }\end{array}$ & 40 & $36-40$ & $38-42$ & $42-50$ & $42-43$ & 10 & 45 & 48 \\
\hline lead oxide & 31 & $28-30$ & $31-35$ & $30-32$ & $26-30$ & 22 & 11 & 21 \\
\hline
\end{tabular}

\subsubsection{Diphonix Resin}

Diphonix Resin was evaluated for removal of contaminant metals in the presence of converted asbestos and asbestos-conversion reagents. Diphonix showed 
reduction of lead oxide dissolved in asbestos-conversion solution. In the presence of dissolved glass from a beaker, the reduction from ion exchange was $35 \%$, and $30 \%$ in the absence of dissolved glass when the test was repeated in a plastic beaker.

Diphonix also allowed a small reduction (11\%) in concentration of ammonium diuranate from asbestos-conversion solution.

The inhibiting effect of the solutes in the asbestos-conversion solution was shown during testing of uranium from uranyl nitrate in formic acid at $\mathrm{pH} 3.5$. Whereas the removal was virtually none in the asbestos-conversion solution, the absence of these solutes allowed $84 \%$ removal in a single batch contacting (sample 62).

The inhibiting effects of the asbestos-conversion solutes can be overcome with massive application of ion exchange resin. Samples 63 and 64 in which no uranium uptake was measured for ammonium diuranate and uranyl nitrate in the presence of 0.3 grams of resin, showed $30 \%$ and $34 \%$ removal with addition of another 20 grams of resin. In this case, the competing ions, which include iron, calcium, magnesium, nickel, tin, boron, barium, molybdenum, and titanium, were most likely removed sufficiently to allow dissolution and uptake of uranium.

\subsubsection{Reillex Resin}

Reillex resin, evaluated in the presence of converted asbestos and asbestosconversion reagents, did not show particular removal except for one sample in which 28 percent of the lead was removed from a solution of lead oxide in asbestosconversion solution.

\subsubsection{Amberlite-900 Resin}

Amberlite-900 Resin, evaluated in the presence of converted asbestos and asbestos-conversion reagents, was effective only in removal of lead from a solution of lead oxide in asbestos-conversion solution with $27 \%$ removal.

\subsubsection{Amberlite-400 Resin}

Amberlite-400, evaluated in the presence of converted asbestos and asbestosconversion reagents, was effective only in removal of lead from a solution of lead oxide in asbestos-conversion solution (sample 51 ) with $34 \%$ removal. 


\subsubsection{Amberlite IRC-718}

Amberlite IRC-718, evaluated in the presence of converted asbestos and asbestos-conversion reagents, had no appreciable effect in removal of uranium from ammonium diuranate or uranyl nitrate solutions. It was somewhat effective in removal of uranium trioxide ( $76 \%$ removal) and lead oxide (48\% removal) from the asbestos-conversion solution.

\subsubsection{Hydrogel}

Allied Signal in Morristown, NJ has developed a polymeric resin material, Hydrogel, that has proven particularly effective in metal removal from solution. Hydrogel has a strong affinity for uranium.

Samples of converted-asbestos suspension, doped at $43 \mathrm{ppm}$ by weight metal with ammonium diuranate, uranyl nitrate, uranium trioxide, and lead oxide, were sent to Allied Signal. Allied Signal's procedure was to contact $20 \mathrm{ml}$ of solution with $0.2 \mathrm{~g}$ of Hydrogel, contact with gentle shaking overnight, separate the resin and solution by filtering, and assay the filtrate by ICAP. The tests were repeated using a clay that Allied Signal has found effective.

The expected metal removal for Hydrogel is 4 milli-equiv/gram for uranium. In the removal of ammonium diuranate the amount of uranium removed was 2.35 $\mu$-equivalents. Accordingly, the take-up of uranium was $11.76 \mu$-equivalents/gram.

In the removal of lead oxide the amount of lead removed was $5.85 \mu$ equivalents. Accordingly, the take-up of lead was $0.0293 \mathrm{~m}$-eq/gram. These values for specific uptake exploit less than $1 \%$ of the expected Hydrogel capacity. The results suggest that other ions are competing for the sites on the Hydrogel.

Subsequently, Allied Signal carried out column tests on asbestos-conversion supernate. While the Allied Signal Hydrogel offered the best ion exchange performance of the resins tested, it was not sufficient under the adverse conditions of the acidic, saturated, fluoride-containing solution following asbestos conversion.

\subsubsection{Ion Exchange Screening in Simpler Solutions}

Since all testing in doped ABCOV solutions could not meet performance criteria, a few exploratory tests were designed to evaluate the capture of contaminant 
metals in the absence of fluorides, silicates, binders, and other compounds that would be present from contact with the asbestos-conversion reagent. WSTC investigated uptake of uranium and lead in water and uncontaminated weak acid.

\subsubsection{Sample Preparation Procedure}

The procedure was to dissolve contaminant compounds at a concentration of $43 \mathrm{ppm}$ by weight contaminant metal in water or 10 volume \% formic acid solution in the presence of asbestos.

After shaking for one hour, the clear solution was filtered from the mixture. The metal concentrations relate to the maximum expected in process solutions in the commercial process.

Half of the solution was retained as a control; the other half was contacted for two hours with Amberlite IRC-718. A ten-fold excess of ion exchange resin was contacted with the solution. The resultant clear liquids were assayed for metal content.

\subsubsection{Test Results}

The results of these experiments are listed in Table 4.7.

Table 4.7 - Effect of Solution on Ion Exchange Uptake

\begin{tabular}{|l|l|l|l|}
\hline Solvition & \multicolumn{1}{|c|}{ Water } & Formic Acid & \multicolumn{1}{|c|}{$\begin{array}{c}\text { ABCOV } \\
\text { Solution }\end{array}$} \\
\hline Urantaminant & \multicolumn{3}{|c|}{$\%$ Removal } \\
\hline $\begin{array}{l}\text { ammonium di- } \\
\text { uranate }\end{array}$ & $\begin{array}{l}\text { Solids did } \\
\text { not dissolve }\end{array}$ & 61 & 1 \\
\hline $\begin{array}{l}\text { uranium triox- } \\
\text { ide }\end{array}$ & $\begin{array}{l}\text { Solids did } \\
\text { not dissolve }\end{array}$ & 55 & 7 \\
\hline lead oxide & 59 & 34 & 48 \\
\hline
\end{tabular}

These results indicate that: 
- Solubility of the contaminant species is limited in pure water, but it is more complete in weak acid.

- The metal uptake of uranyl nitrate and ammonium diuranate increased in the absence of fluorides. Percent removal of uranium from the acidic solution ranged between 34 and $61 \%$ as contrasted with the lower levels of removal in the presence of fluoride and asbestos-decomposition products.

- The acidic conditions do not allow sufficient uranium removal.

At this point, WSTC abandoned the effort to remove contaminant metals from the acidic asbestos-conversion suspension and reconfigured the proposed process to allow a workable metals removal system. Experience in solution mining of uranium and washing of uranium and lead from contaminated soil suggested chemistry that would allow separation of uranium from lead and removal of both cationic and anionic uranium from solution.

\subsection{ION EXCHANGE TESTING OF REVISED CONCEPT IN ALKALINE SOLU- TION}

The previous experiments in this program showed that the chemicals from the asbestos-conversion reagents and the chemical species formed from conversion of asbestos compete for ion exchange availability for metals in solution and inhibit dissolution of contaminants into the saturated solution.

Accordingly, the fundamental process arrangement was changed from the initial concept of beginning the process with asbestos conversion to converting asbestos after both the organics and uranium have been removed. The slightly alkaline environment of ammonium carbonate allows dissolution of both cationic and anionic uranium as ammonium bicarbonate $\left(\mathrm{NH}_{4}\right)\left(\mathrm{UO}_{2}\right)\left(\mathrm{HCO}_{3}\right)_{3}$. The following experiments were proposed to test the removal of uranium under alkaline conditions, in the absence of fluorides, silicates, and other compounds that would be present from contact with the $\mathrm{ABCOV}$ reagent. 


\subsubsection{Test Procedures in Alkaline Solution}

The procedure for contacting contaminants with ion exchange resin in the presence of ACM was to dissolve the contaminants in a mixture of finely milled ACM, deionized water, and ammonium carbonate $\left(\mathrm{NH}_{4}\right)_{2} \mathrm{CO}_{3}$, while stirring. The $\mathrm{pH}$ was adjusted to 9 to 9.5 with $\mathrm{NaOH}$ solution. This mixture was split in half. Half was retained as a control; the other half was ion exchanged with Dowex 21K. Both halves were shaken for 2 hours on a shaker table. From each of the beakers, a centrifuge isolated filtered, clear solution, which was assayed for contaminant metal content.

The resin chosen for the alkaline tests, Dowex $21 \mathrm{~K}$, is a weak-acid anionic resin with particle size between 16 and 30 mesh. This resin has served well in earlier Westinghouse work, particularly soil washing for uranium removal and solution mining for uranium. It is important to note that this resin is suited to an alkaline medium, unlike the others studied, which are suited to the acidic conditions of the ABCOV chemistry.

After contacting the resin with solution, the resin was stripped with nitric acid to remove the contaminant. Residual resin and the stripping solution were assayed to provide a mass balance.

\subsubsection{Ion Exchange Tests in Alkaline Solution}

The results of all experiments involving uptake of contaminant metals by ion exchange in alkaline solution are summarized below.

\begin{tabular}{|c|c|c|c|}
\hline \multicolumn{4}{|c|}{$\%$ Removal of } \\
\hline Uranyl nitrate & $\begin{array}{c}\text { Ammonium } \\
\text { diuranate }\end{array}$ & $\begin{array}{c}\text { Uranium } \\
\text { trioxide }\end{array}$ & $\begin{array}{c}\text { Lead } \\
\text { oxide }\end{array}$ \\
\hline 91.4 & 99.5 & 99.4 & 99.0 \\
\hline
\end{tabular}

More detail on the mass balance obtained in the uptake and regeneration of ion exchange resin with uranium under alkaline conditions is provided in Table 4.8. 
Table 4.8 - Alkaline Ion Exchange Mass Balance Data

\begin{tabular}{|l|c|c|c|c|c|c|}
\cline { 2 - 7 } \multicolumn{1}{c|}{} & \multicolumn{6}{c|}{ mg Metal \{\% weight of total metal \} } \\
\hline Contaminant & $\begin{array}{c}\text { Metal } \\
\text { Input }\end{array}$ & $\begin{array}{c}\text { Remaining } \\
\text { Liquid }\end{array}$ & $\begin{array}{c}\text { Stripped } \\
\text { from } \\
\text { ACM }\end{array}$ & $\begin{array}{c}\text { Striped } \\
\text { from Resin }\end{array}$ & $\begin{array}{c}\text { Residual } \\
\text { Resin }\end{array}$ & $\begin{array}{c}\text { Closure, } \\
\%\end{array}$ \\
\hline ammonium & 23.00 & 0.097 & 0.396 & 18.200 & .005 & 82 \\
diuranate & & $\{0.4 \%\}$ & $\{2 \%\}$ & $\{79 \%\}$ & $\{0.02 \%\}$ & \\
\hline uranium tri- & 20.70 & 0.109 & 0.321 & 20.300 & 0.002 & 100 \\
oxide & & $\{0.5 \%\}$ & $\{1.6 \%\}$ & $\{98 \%\}$ & $\{0.01 \%\}$ & \\
\hline lead oxide & 2.371 & 0.225 & 1.7947 & 0.032 & .0003 & 87 \\
& & $\{9.5 \%\}$ & $\{76 \%\}$ & $\{1 \%\}$ & $\{0.01 \%\}$ & \\
\hline
\end{tabular}

The destinations of contaminants are shown in the following stacked bar graph, Figure 4.7. It was assumed that all contaminant was stripped from resin. Values are normalized for $100 \%$ closure.

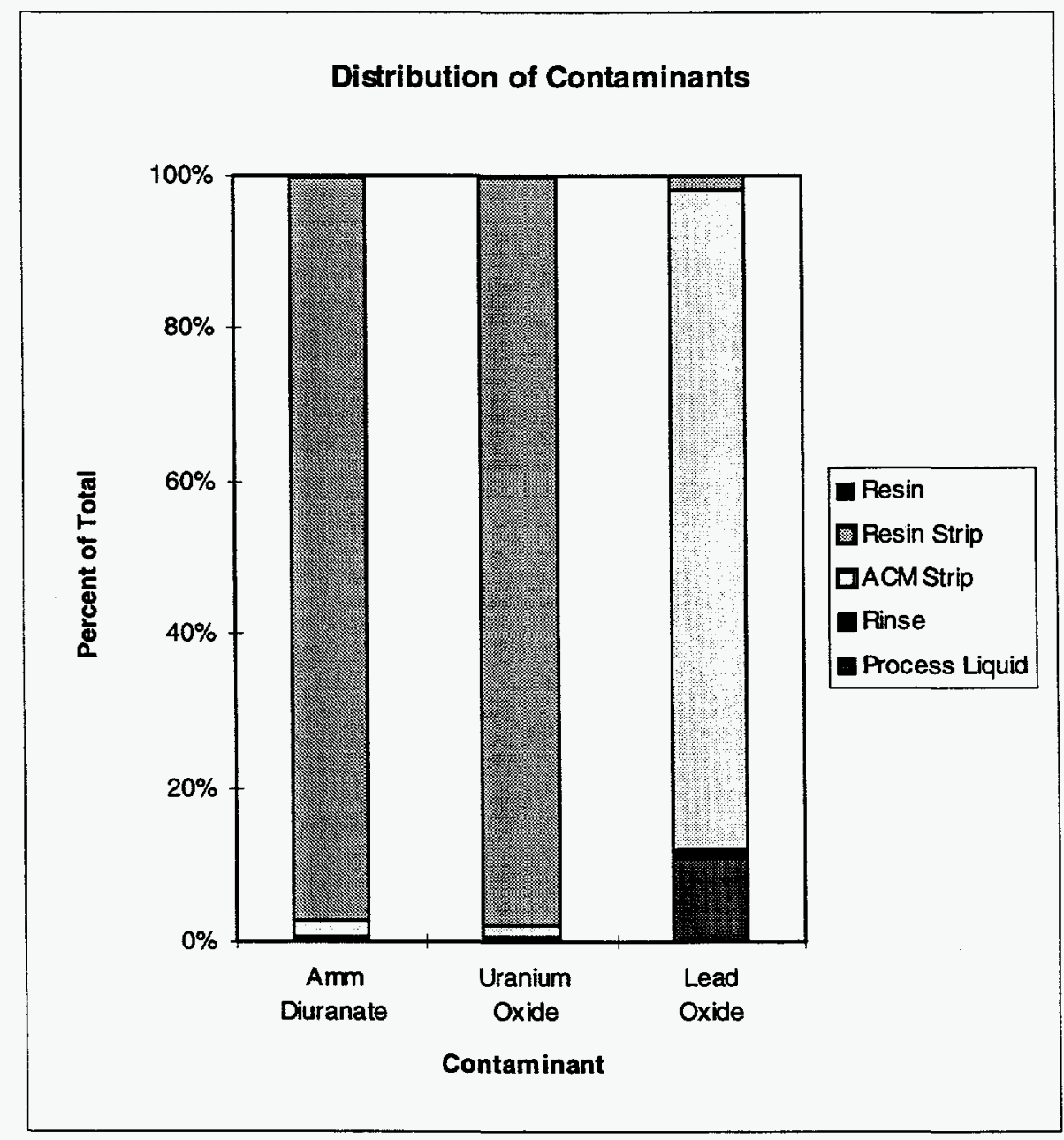

Figure 4.7 - Distribution of contaminants in the ion exchange processing with Dowex K-21 Resin. 
Table 4.8 and Figure 4.7 show that the anionic ion exchange resin is effective in capture of uranium and that it can indeed be effectively stripped from the resin with nitric acid.

Lead, on the other hand, insoluble under alkaline conditions, is not captured by the ion exchange resin, but remains on the asbestos. In this experiment, the lead oxide was indeed stripped from the asbestos and recovered, but in the commercial process, would remain alkaline and would remain undissolved on the asbestos. Under these process conditions, some lead does remain with the process liquid. This liquid will circulate within the system and its lead too will remain recirculating within the system.

This experimental study with the three contaminant species complements the successful test with uranyl nitrate and demonstrates that uranium in any of its expected forms can be removed from asbestos while lead remains.

\subsubsection{Resin Loading Tests with Urynal Nitrate Tests}

In order to determine an indication of resin loading, the Dowex $21 \mathrm{~K}$ resin that was used to remove uranyl nitrate was subjected to two additional bathes of urynal nitrate solution. The additional contaminant removal obtained on each contact with uranyl nitrate solution is summarized in Table 4.9 , along with the total resin loading.

Table 4.9 - Resin Loading Tests

\begin{tabular}{|l|c|c|c|c|c|}
\hline Contact & \multicolumn{3}{|c|}{ Concentration of Uranium, ppm } & \multicolumn{2}{c|}{ Loading on Resin } \\
\hline & feed (control) & final & Removal & mg U & $\begin{array}{c}\text { eq/liter } \\
\text { cumulative }\end{array}$ \\
\hline first & 33 & 2.9 & 91 & 6.02 & .26 \\
second & 71 & 38.6 & 46 & 6.48 & .54 \\
third & 71 & 66.9 & 6 & .82 & .57 \\
\hline
\end{tabular}

The carbonate in solution, maintained at $\mathrm{pH} \sim 9$ formed the bicarbonate, which solubilizes uranium. It is evident that uranium in alkaline solution did indeed dissolve and was taken up by the ion exchange resin, which demonstrates that the cationic uranium is converted to the anionic complex and taken from solution by the anionic resin. 
The extent of removal in the first stage of batch contacting was $91 \%$. These results indicate that the uranium in a continuous column operation can be removed virtually completely.

The extent of adsorption by the resin increased asymptotically, indicating a capacity of the resin under these conditions of about 0.6 equivalents per liter, which is very acceptable and exceeds the criterion for success of 0.4 equivalents/liter, as established in the test plan.

This mass balance provided a closure of the mass balance at $103.8 \%$. This tight closure gives final assurance of the accuracy of assays.

\subsubsection{Regeneration of the lon Exchange Resin}

The mixture of uranium-loaded resin and asbestos was slurried with $200 \mathrm{ml}$ of water and separated into asbestos fibers and resin beads with a 40-mesh sieve, which allowed $90 \%$ recovery of the resin. A solution of $25 \mathrm{wt} \%$ nitric acid was stirred with the contaminant-containing resin for 1 hour. The liquid recovered was assayed for uranium.

The recovered liquid was assayed for uranium at $69.21 \mathrm{ppm}$. The yield of uranium was accordingly $7.69 \mathrm{mg}$. The percent recovery was $57.8 \%$.

The total of $560 \mathrm{ml}$ of decanted water used in separating resin from asbestos was assayed at $0.41 \mathrm{ppm}$ uranium for which the total uranium was $0.23 \mathrm{mg}$ or $1.7 \%$.

The ACM recovered was also acid-stripped with nitric acid for uranium recovery. The $82 \mathrm{ml}$ of nitric acid recovered assayed at $4.4 \mathrm{ppm}$, a yield of $0.36 \mathrm{mg} \mathrm{U}$ or $2.7 \%$.

Dissolution with nitric acid proved to be an effective means of stripping uranium from the resin. Batchwise stripping is less effective than the continuous-stage process of column regeneration. The criterion for success in this experiment, set at $50 \%$, was exceeded at actual recovery of $57.8 \%$. 


\subsection{DISCUSSION OF ION EXCHANGE STUDIES AND CHARACTERIZATION}

The metals removal test program provided three main areas of investigation, characterization of the $\mathrm{ABCOV}$ suspension, ion exchange testing in acid solution, and ion exchange in alkaline solution.

\subsubsection{Characterization of the Asbestos-Conversion Suspension}

Characterization of the milky suspension of converted-asbestos suspension revealed that:

- The particles of converted asbestos are exceedingly fine, typically 1 micron and smaller. These particles are difficult to remove from suspension and would tend to foul ion exchange resin.

- The solution contains a high level of dissolved metals that compete in ion exchange.

- The solution, as formulated, contains a high level of fluorides which are adverse to ion exchange.

These characteristics have the following implications on solution processing.

Solids Separation: The ABCOV suspension is composed of an abundance of fine particles that are extremely difficult to settle. The predominance of sub-micron particles will give the suspension characteristics of a colloid that separates very slowly. According to Stokes's law for 1 micron particles in water settling through 1 meter of suspension would take 10.7 days, which is of the same order of magnitude observed in settling tests. In actuality, the compressive settling or thickening would require even longer.

The abundance of exceedingly fine particles in the suspension will make separation difficult, foul ion exchange media, and encourage carryover of solids. An option that may aide in the processing of this suspension is to convert ACM under those conditions that will avoid production of micro-fines.

Solution Chemistry: The asbestos-conversion suspension contains a high concentration of total dissolved solids (TDS). A concentration of 5.1\% TDS reflects the dissolution of asbestos during the conversion process. The apparent value of $16.3 \%$ re- 
sulting from dissolution of the glass beaker indicates the strong dissolving power of the asbestos-conversion reagents and provides a caution to avoid contact of the reagent with glass equipment in the field or in the laboratory.

The solution resulting from conversion of asbestos is highly concentrated in a number of elements, indicating high or saturated levels of some elements. This condition offers ions, notably iron, calcium, magnesium, nickel, tin, boron, barium, molybdenum, and titanium, that may compete for sites in ion exchange. The high concentrations of solutes limit the solubility of contaminant metal salts in the solution, and they compete, owing to both abundance of selectivity (tendency to attach), for the resin. Furthermore, the presence of fluoride, a component of the ABCOV reagent, will compete strongly for anionic ion exchange sites.

\subsubsection{Ion Exchange from the Asbestos-Conversion Acidic Solutions}

Application of a number of ion exchange resins revealed that ion exchange is encumbered disastrously in the presence of the asbestos-conversion products:

- The high concentration of dissolved asbestos hinders dissolution of contaminants (uranium and lead).

- The high concentration of fluoride inhibits ion exchange.

Contaminant-partitioning results suggest that if ion exchange were to be performed after asbestos conversion, uranium from the ammonium diurinate solution would not precipitate and would be available for capture by ion exchange. Conversely, iron, calcium, and magnesium will tend to precipitate as fluorides along with the lead, allowing separation of non-radioactive metals along with the silica solids.

Maintaining the chemistry of the asbestos-conversion solution was a constraint. The reagents making up the asbestos-conversion solution are costly: both $\mathrm{pH}$ and fluoride concentration must be maintained to allow recycle of this reagent stream. In order to process the $\mathrm{ABCOV}$ solution as initially envisioned, it is necessary to separate solids from the suspension of converted asbestos. In addition, the integrity of the $\mathrm{ABCOV}$ reagent must be retained so that it can be recycled. To al- 
low recycle, fluoride cannot be destroyed, and the $\mathrm{pH}$ cannot be adjusted to allow precipitation of salts.

Continual failure in achieving ion exchange under the conceptual process conditions led to a restructuring of the process in which removal of contaminants by ion exchange would be carried out prior to asbestos conversion. Examination of ion exchange in the absence of asbestos-conversion reagents gave heartening results immediately.

\subsubsection{Ion Exchange in Alkaline Solution}

Ion exchange in the absence of the asbestos-conversion chemistry allowed two favorable conditions:

- First, the ion exchange could be practiced in alkaline, bicarbonate solution which is particularly favorable for dissolving uranium compounds and placing them in anionic form.

- Second, lead compounds could be kept out of solution, this allowing immediate and thorough separation of the toxic lead and the radioactive uranium.

A series of ion exchange experiments with lead oxide and uranium as anionic ammonium diuranate, cationic uranyl nitrate, and uranium trioxide demonstrated that uranium could indeed be removed effectively by ion exchange while lead remained insoluble and trapped in the solid form. Adequate resin loading was achieved in uranyl nitrate uptake tests. Finally, stripping with nitric acid demonstrated that uranium can be readily recovered from the ion exchange resin.

\subsection{PROPOSED PROCESS FOR MIXED WASTE REMEDIATION}

The overall Mixed Waste Processing System for asbestos decontamination is a unified system that provides complete decontamination of asbestos from weaponsproduction plants. A process flow diagram is presented in Figure 4.8. The system integrates: 
Stream designators are in squares. Unil operation designators are in ovals. Shading designates input streams.

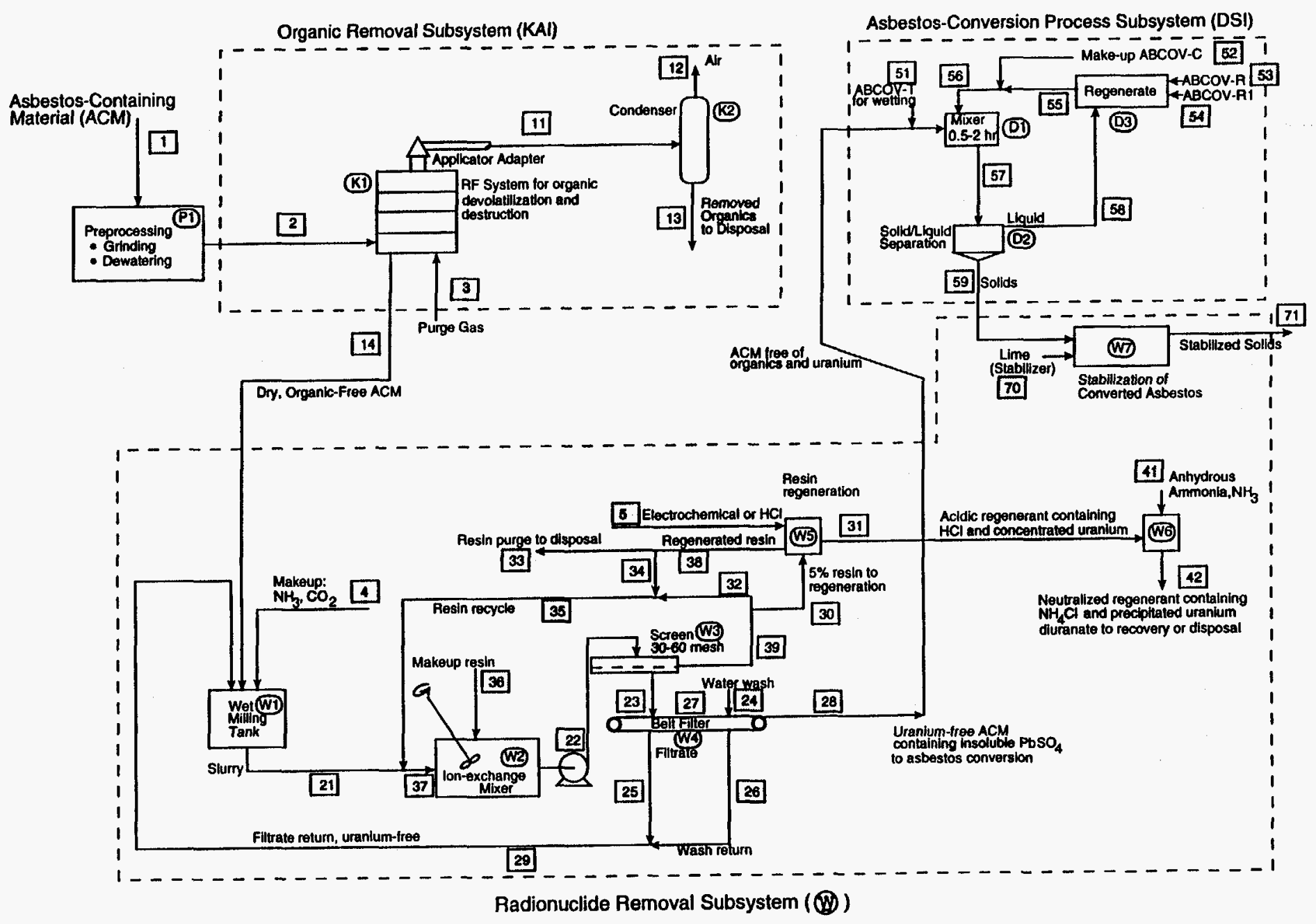

Figure 4.8 - Process Flow Diagram for Mixed Waste Remediation of Asbestos. 
- radio frequency technology for volatilizing or destroying organics

- chemical and electrochemical technology for sequestering of hazardous and radioactive metals

- chemical conversion of asbestos to harmless, amorphous solids.

The process begins with receipt of asbestos, actually asbestos-containing material or ACM, which in processing step P1 is reduced to smaller than one-inch mesh size and is dewatered by pressing, spinning, heating, or air drying depending upon its form.

At processing step $\mathrm{K} 1$, the dry ACM encounters radio frequency energy, tuned to the resonant frequency of the asbestos, which provides for rapid devolatilization. The vaporized organics or organic reaction products are condensed at $\mathrm{K} 2$ and are sent to final disposal. Contaminant metals remain with the ACM.

The dry, organic-free ACM is transported to $\mathrm{W} 1$ where it is wet milled into slightly alkaline ammonium bicarbonate solution. The resulting slurry contains solubilized uranium and insoluble ACM and lead or lead compounds.

The slurry exiting $\mathrm{W} 1$ contacts ion exchange resin at $\mathrm{W} 2$, where the soluble uranium compounds are captured. Next, the screen at W3 separates resin for recycling to the Mixer W2, and the uranium-free slurry of ACM and insoluble lead exits to the belt filter at W4. Filtrate returns to the Wet Milling Tank at W1 and the ACM, being washed on the same filter belt, is acidified slightly and moves to the asbestos-conversion processing.

A fraction of the resin is continuously regenerated in the Chemical/Electrochemical cell at W5. This regenerated resin returns to the Mixer. Concentrated uranium compounds exit the cell and are neutralized and precipitated with anhydrous ammonia at W6. The neutralized insoluble concentrate exits to disposal or recovery.

The moist, slightly acidic, ACM from W4 moves to D1 where asbestos conversion occurs under the chemical action of $\mathrm{ABCOV}$ reagents. The slurry exiting $\mathrm{D} 1$ flows to D2 where it separates into a clear recycle stream that flows to D3 for regen- 
eration and a stream of dewatered, converted-asbestos solids. The convertedasbestos solids flow to $\mathrm{W} 7$, where stabilizers are added to produce a non-leaching solid.

A mass balance provided in Table 4.10 indicates the expected flow rates of input and output streams. Using the current separation concept, the fate of each major contaminant is as follows:

- Radioactive material (i.e., uranium) is dissolved into the liquid phase and captured on ion exchange resin. The resin is regenerated, concentrating radioactive material in regenerator output and resin purge streams, Streams 42 and 33 . A $100 \mathrm{~kg} / \mathrm{hr}$ feed of asbestos segregates about 1.4 $\mathrm{kg} / \mathrm{hr}$ of radioactive waste.

- Organics are volatilized and condensed. A $100 \mathrm{~kg} / \mathrm{hr}$ feed of asbestos produces a $0.01 \mathrm{~kg} / \mathrm{hr}$ segregated organic condensate stream for incineration.

- Lead, in the current process, remains in the solid phase with the converted asbestos. Assuming dewatering of converted solids to $50 \%$ solution and a 1:1 stabilizer to waste weight ratio, the stabilized solids will exit at about $400 \mathrm{~kg} / \mathrm{hr}$. Although the weight of material disposed of as solidified solids is increased by addition of stabilizer, the volume of material disposed of is decreased owing to the elimination of porosity and interparticle voids in the crushed, low-density ACM bats, fill, and lagging. Overall volume reduction, using this processing scheme, is estimated at $40 \%$ to $60 \%$.

Processing options that further volume and weight reduce the residual waste streams can be investigated in Phase 2 . One possibility is for the removal, as opposed to sequestering, of lead in the process described in Figure 4.8. The uraniumfree stream exiting the belt filter (W4) can be acidified to dissolve lead. Ion exchange is well suited to actual removal of lead at this point, and the lead-free ACM can be converted, as before. This allows the possibility of stabilizing only a small, heavy metal waste stream, rather than the entire converted-asbestos stream. 
Table 4.10 - Overall Mass Balance for the Mixed Waste Processing System

\begin{tabular}{|c|c|c|c|c|c|c|c|c|}
\hline \multicolumn{9}{|c|}{\begin{tabular}{|l|l|} 
Mass Balance for the Electromagnetic, Mixed-Waste Process & \\
\end{tabular}} \\
\hline & \multicolumn{8}{|c|}{ Note: this mass balance includes only selected streams and the major components. } \\
\hline & \multicolumn{8}{|c|}{ Minor components are grouped with others in, for example, "other solids". } \\
\hline & \multicolumn{8}{|c|}{ Units are in $\mathrm{Kg} / \mathrm{hr}$ on a basis of $100 \mathrm{Kg} / \mathrm{hr}$ input of asbestos-containing material (ACM). } \\
\hline & & & & & & & & \\
\hline & \multicolumn{8}{|l|}{ Process linull } \\
\hline & & & & & & & & \\
\hline Stream & ACM & Milled, & $\mathrm{ACM}-$ & Ion-Exch- & Condenser & Stabilized & Regenerant & Resin Purge \\
\hline \multirow[t]{2}{*}{ Description } & Input & Wet ACM & Conversion & Treated Solids & Bottoms & Solids & Output & \\
\hline & & & \multicolumn{2}{|c|}{ Reagent Input } & & & & \\
\hline \multirow{2}{*}{\multicolumn{9}{|c|}{ streamt: }} \\
\hline & & & & & & & & \\
\hline Asbestos & 60 & 60 & & 60 & & 60 & & \\
\hline Other Solids & 39.89 & 39.89 & & 39.89 & & 39.89 & & \\
\hline Organics & 0.01 & & & & 0.01 & & & \\
\hline Uranium & 0.05 & 0.05 & & & & & 0.05 & .00002 \\
\hline Lead & 0.05 & 0.05 & & 0.05 & & 0.05 & & \\
\hline Water & & 1800 & & 99.89 & & & & 0.0433 \\
\hline$\left(\mathrm{NH}_{4}\right)_{2} \mathrm{CO}_{3}$ & & 36 & & & & & & \\
\hline \multicolumn{9}{|l|}{$\mathrm{HCl}$} \\
\hline $\mathrm{ABCOVC}$ & & & 1110 & & & 99.89 & & \\
\hline $\mathrm{NH}_{4} \mathrm{Cl}$ & & & & & & & 1.3 & \\
\hline Lime, $\mathrm{CaO}$ & & & & & & 199.78 & & \\
\hline \multirow[t]{2}{*}{ Ion-Ex Resin } & & & & & & & & 0.0433 \\
\hline & & & & & & & & \\
\hline Total $\mathrm{Kg}$ & 100 & 1936.0 & 1110.0 & 199.8 & 0.01 & 399.6 & 1.3 & 0.087 \\
\hline
\end{tabular}




\section{KAI BENCH-SCALE ORGANIC PROCESSING TESTS}

\section{$5.1 \quad$ INTRODUCTION}

Bench-scale testing of the organic processing of the amorphous silica suspension focused on measurement of its dielectric and thermal properties and testing using radio frequency energy to drive off an organic contaminant (perchloroethylene) with which a sample of the material had been "spiked" (perchloroethylene was substituted for the trichloroethylene mentioned in the Test Plan because of its higher boiling point and lower vapor pressure). A preliminary theoretical model of the bench-scale RF heating process using the measured dielectric and thermal properties of the suspension was also developed and compared to the experimental RF heating data.

\subsection{DIELECTRIC AND THERMAL PROPERTIES OF THE SILICA SUSPENSION}

Measurements of the dielectric properties were conducted at KAI's facilities using Hewlett Packard's 85070A Dielectric Measurement Probe Kit and by Mr. W.B. Westphal formerly of the Massachusetts Institute of Technology (MIT) Insulation Research Laboratory. Figure 5.1 shows a good comparison between the KAI and Westphal dielectric data (conductivity) for pure ABCOV-C which contains no converted ACM. It was assumed that the silica suspension behaved as a lossy dielectric (loss tangent less than 10) for measurement purposes. The loss tangent (conductivity) is a measurement of a material's ability to absorb RF energy. Dielectric measurements were also made using the dielectric probe at $\mathrm{KAI}$ for samples of the ABCOV solution with and without the silica in suspension and containing approximately $1000 \mathrm{ppmV}$ of trichloroethylene (TCE). Data consisting of the dielectric 

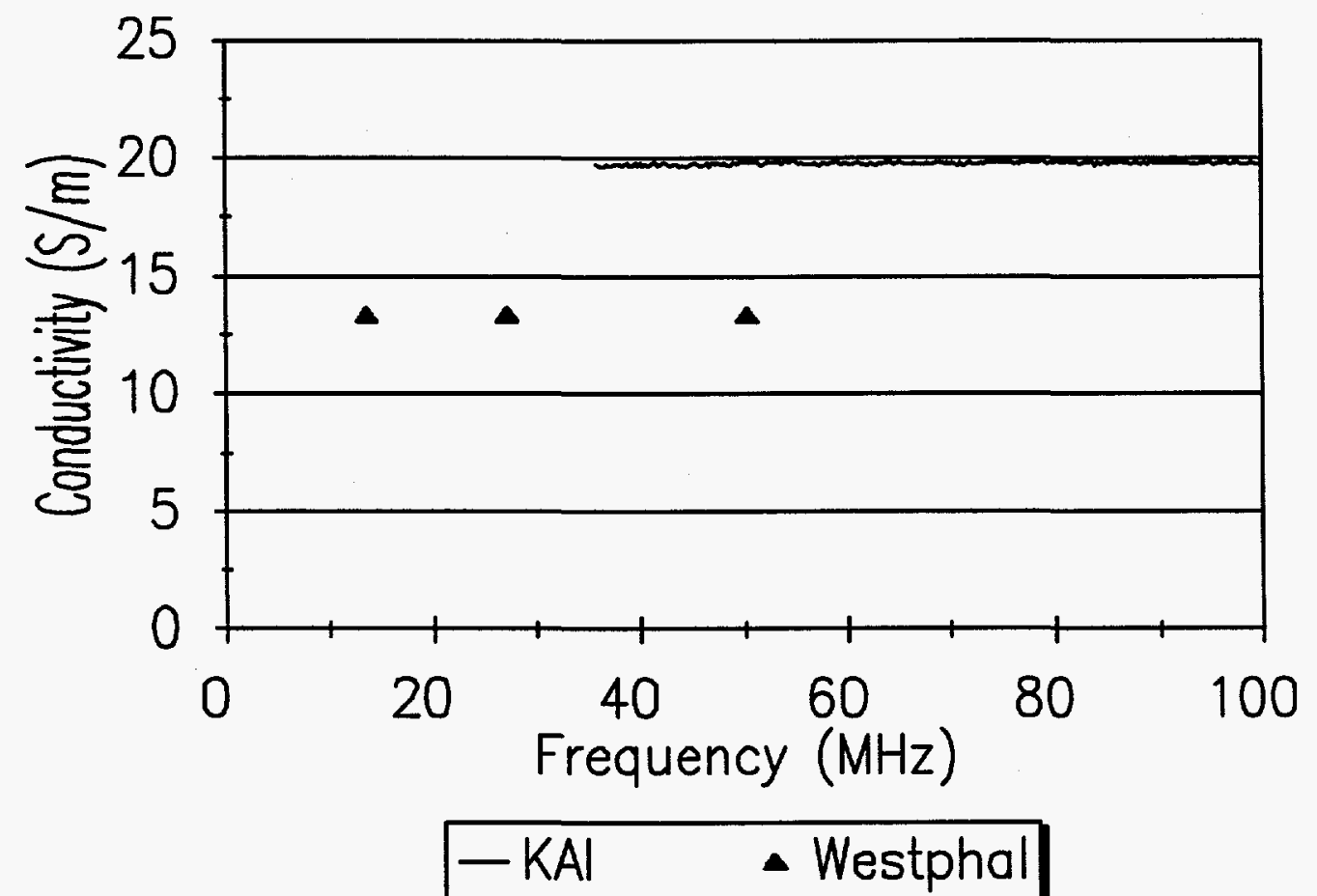

Figure 5.1 - Pure ABCOV-C Conductivity Measurements.

constant and loss tangent are presented for all of these cases and shows that negligible effect is produced on the dielectric properties of the ABCOV solution by the presence of the silica particles or TCE. The results demonstrate that the ABCOV solution is essentially lossy water. Because the ABCOV solution is highly lossy, the relative dielectric constant was unmeasurable with either the KAI or Westphal dielectric measurement technique. However, the dielectric constant value of water is typically in the range of 75 to 80 . The concentrations of silica and TCE or PCE do not effect the complex dielectric constant of the ABCOV solution. 
Figures 5.2, 5.3, 5.4, and 5.5 (note: the $\mathrm{d}$ on the right ordinate in these figures refers to data) show the loss tangent (conductivity) for the pure ABCOV-C solution, the ABCOV solution with the converted ACM (silica) in suspension, the ABCOV solution with the converted ACM (silica) in suspension and $1000 \mathrm{ppmV}$ of TCE mixed in the solution (agitated), and the ABCOV solution with the converted ACM (silica) not in suspension (settled), respectively.

Results demonstrate that the ABCOV solution with or without converted ACM (silica suspension) and with or without TCE have identical dielectric properties. The dielectric loss property is high, demonstrating the ABCOV solution's ability to rapidly absorb radio frequency energy (published data on the low-frequency conductivity of saltwater gives a range of conductivity at $25^{\circ} \mathrm{C}$ of 10 to 100 Siemens per meter for salt $(\mathrm{NaCl})$ concentrations in the range of 100 to 1000 grams of salt per liter of water).

A thermal analysis was conducted at Energy Materials Testing Laboratory on a sample of ABCOV-C. The results are:

Thermal Diffusivity: $\quad 0.00162 \mathrm{~cm}^{2} / \mathrm{sec}$ Specific Heat: $\quad 0.800 \mathrm{cal} / \mathrm{gm}-{ }^{\circ} \mathrm{C}\left(\mathrm{BTU} / \mathrm{bb}-{ }^{\circ} \mathrm{F}\right)$

Thermal Conductivity: $\quad 0.0057 \mathrm{~W} / \mathrm{cm}-{ }^{\circ} \mathrm{C}$ Specific Gravity: $\quad 1.049$

\subsection{LABORATORY RF HEATING TESTS}

A series of four tests were run using the laboratory RF heating system to determine if RF energy could remove organic contaminants from the silica suspension. Initially, trichloroethylene (TCE) was planned to be the candidate contaminant, but it was found to be completely removed from the silica suspension sample during a four-hour control test conducted at ambient temperature using only air sparging. Because of this behavior, a second chemically similar candidate was used, tetrachloroethylene (PCE), which has a higher boiling point than TCE $\left(121^{\circ} \mathrm{C}\right.$ compared to $87^{\circ} \mathrm{C}$ ) and hence a lower vapor pressure. A brief description of each test run using 


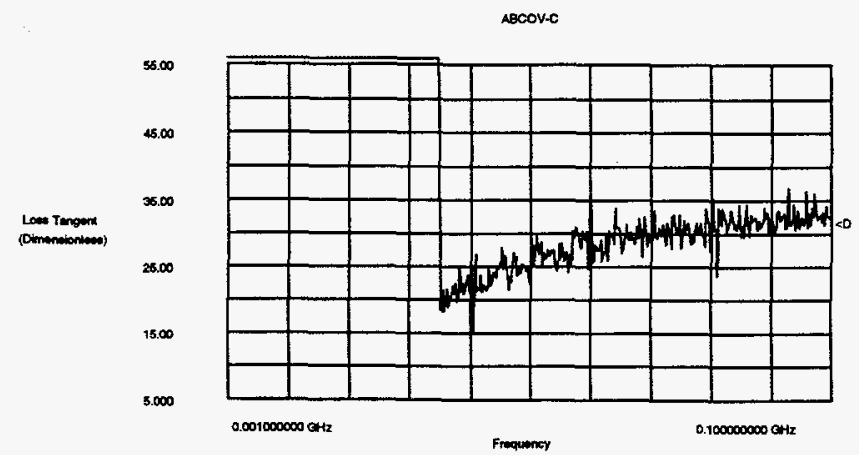

Figure 5.2 - Loss Tangent (Conductivity) Measurement of Pure ABCOV-C

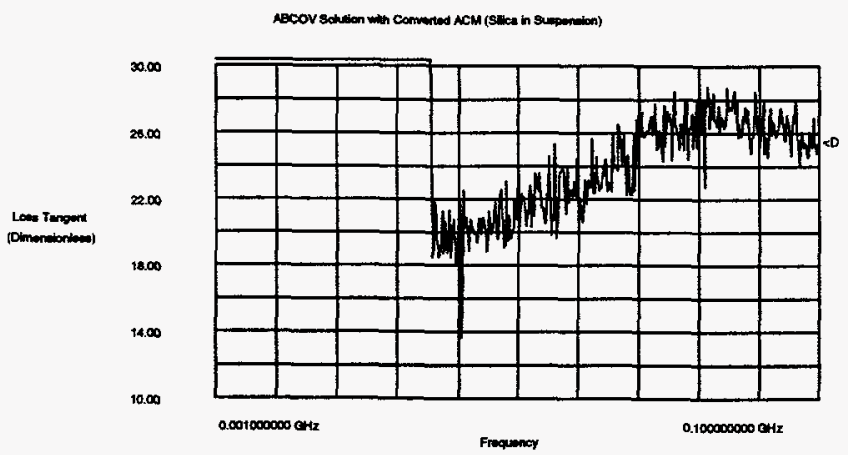

Figure 5.3 - Loss Tangent (Conductivity) Measurement of ABCOV Solution with Converted ACM (Silica) in Suspension 


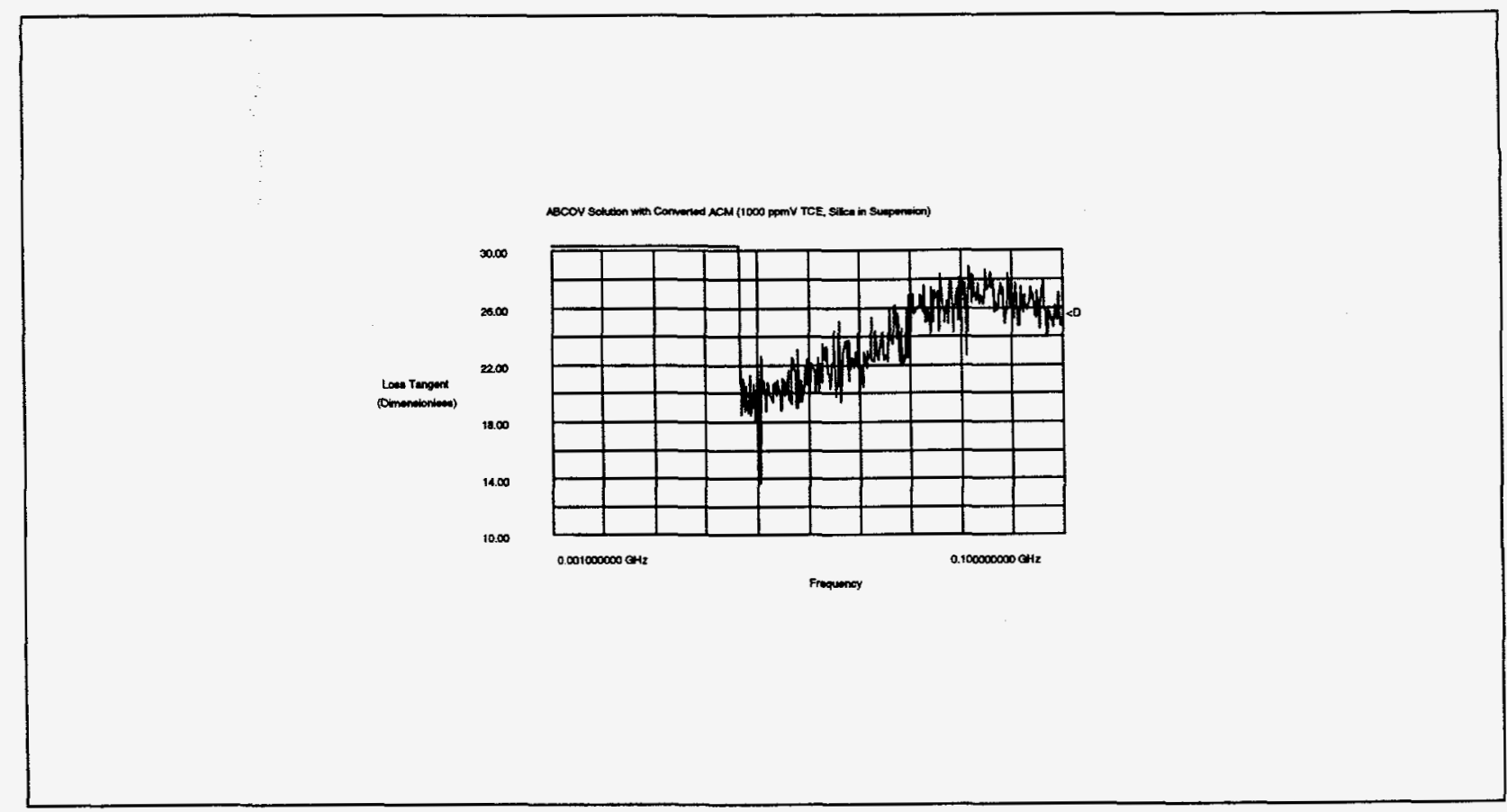

Figure 5.4 - Loss Tangent (Conductivity) Measurement of ABCOV Solution with Converted ACM (Silica) in Suspension and 1000 ppmV TCE Added

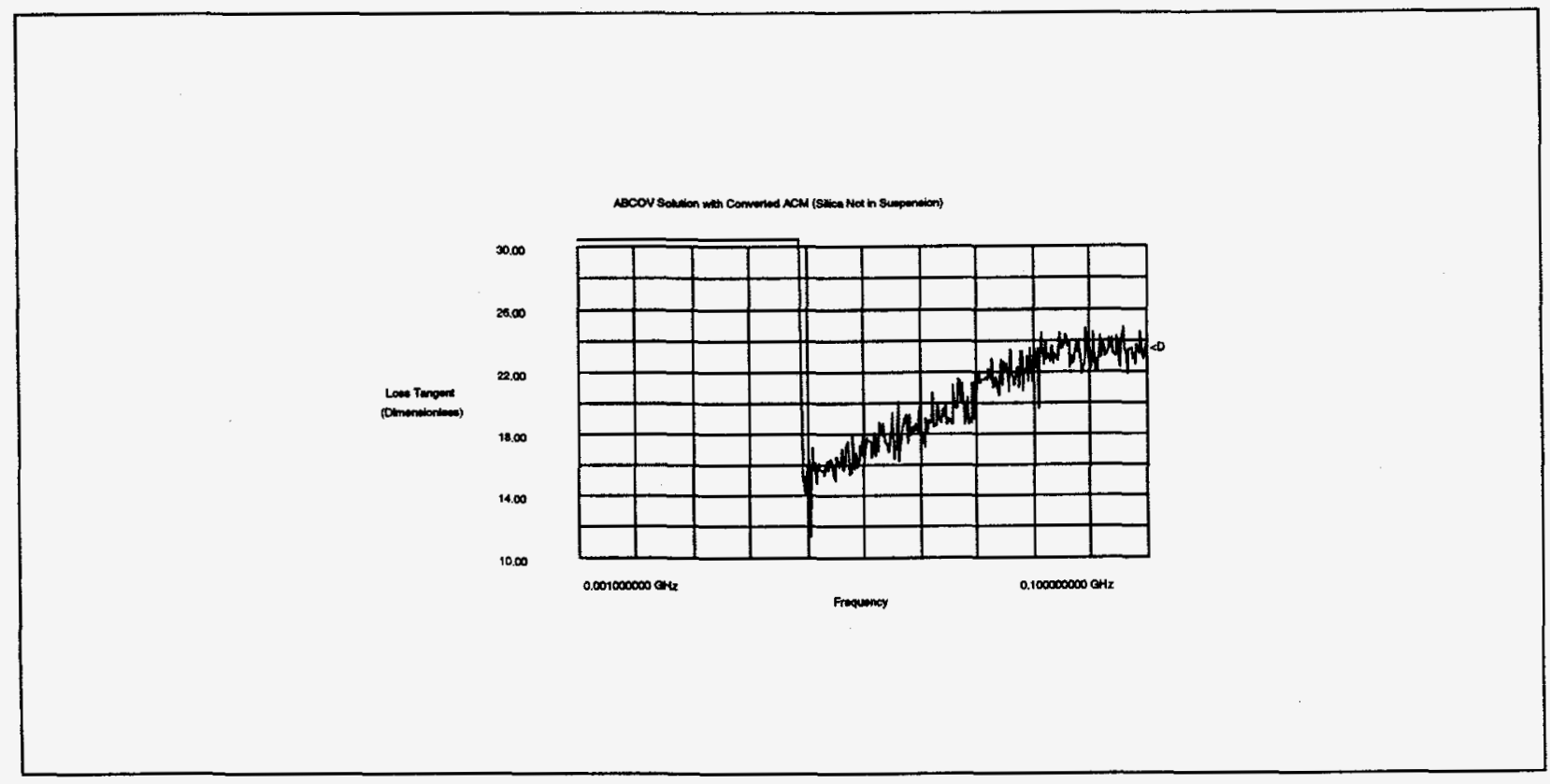

Figure 5.5 - Loss Tangent (Conductivity) Measurement of ABCOV Solution with Converted ACM (Silica) Not in Suspension (Settled) 
PCE as the contaminant follows:

Test 1 - a shakedown test designed to verify that a $1400 \mathrm{cc}$ sample of the silica suspension could be raised to a goal temperature of $90^{\circ} \mathrm{C}$ (measured at the interface between the RF applicator ${ }^{*}$ and the solution).

Test 2 - a control test which was conducted over a four-hour period at ambient temperature using only air sparging on a $1400 \mathrm{cc}$ sample of the silica suspension containing $1.4 \mathrm{cc}$ of PCE (1000 ppmV). After the addition of the PCE, air sparging was used for mixing for a period of 10 minutes prior to the start of the RF heating cycle.

Test 3 - a six-hour RF heating test similar to Test 1 except the silica suspension sample contained $1.4 \mathrm{cc}$ of PCE. Analytical samples were taken at the start of this test and every half hour thereafter for determination of the removal of PCE.

Test 4 - repeat of Test 3.

The optimum temperature required for the complete volatilization of the PCE is calculated to be the approximately the boiling-point temperature $\left(121^{\circ} \mathrm{C}\right)$. During testing the temperature measurement was made at a point adjacent to the applicator. The applicator was maintained at approximately $65^{\circ} \mathrm{C}$ by a heating tape wrapped around the applicator adapter, minimizing heat losses. By simple linear extrapolation, a measured interface temperature of $90^{\circ} \mathrm{C}$ corresponds to an $\mathrm{ABCOV}$ solution temperature of $115^{\circ} \mathrm{C}$ (next to the applicator).

\subsection{DETAILED DESCRIPTION OF BENCH-SCALE TESTS}

\section{Test 1 (Shakedown)}

This test was conducted to shakedown the laboratory RF heating system by determining the heating rate and the system's efficiency in delivering power to the

\footnotetext{
*a 2-inch diameter, 8-inch long monopole antenna (see Figure 5.6)
} 


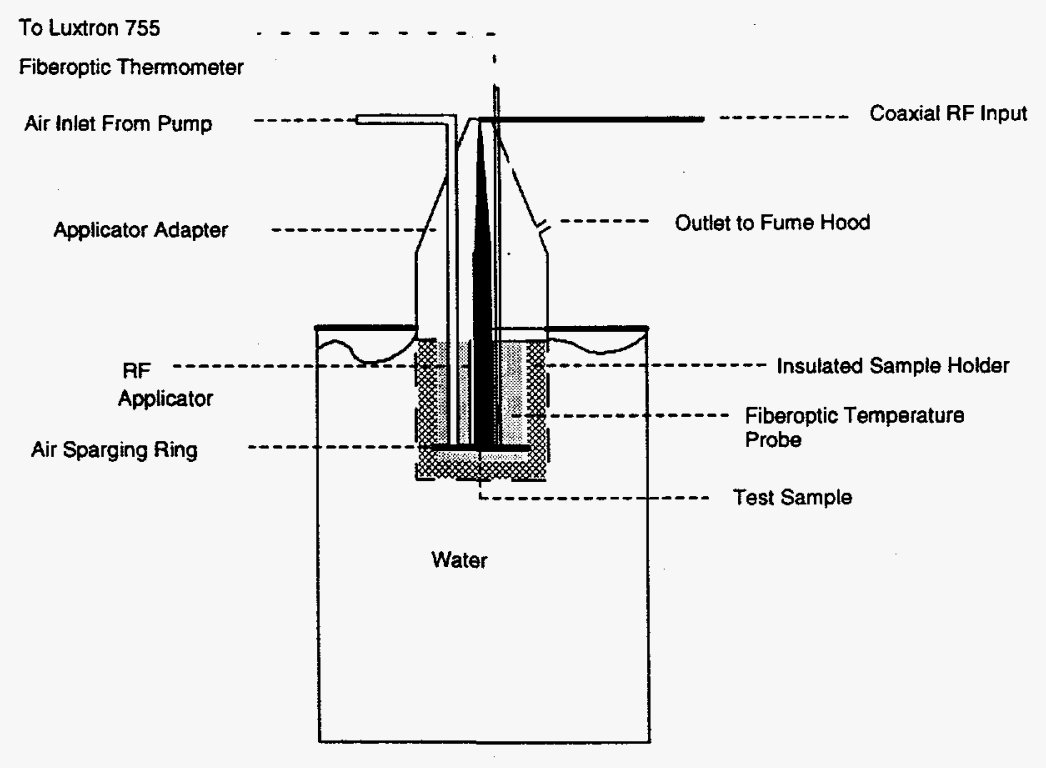

Figure 5.6 - RF Retort with ABCOV Solution Sample Holder.

silica suspension sample. A $1400 \mathrm{cc}$ silica suspension sample was heated at $\mathbf{6 7 . 5 7 7 5}$ $\mathrm{MHz}$ for four hours. During the first half hour, the silica suspension was agitated using air sparging for 1 minute out of every 10 minutes (10\%) and then for $20 \%$ of the time for the remainder of the test. Figure 5.7 shows the interface temperature of the sample measured on the outside of the applicator and the RF power that was supplied to it (see Figure 5.6 (above) for placement of the temperature sensor). Figure 5.8 is the voltage standing wave ratio" (VSWR) measured over a frequency

" VSWR is a measure of how well matched the impedance of the load (RF applicator) is to the impedance of the transmission line. A VSWR of 1:1 corresponds to a perfect match (100\% transmission) and results when the impedance of the load and the transmission line are identical (in this case 50 ohms). 


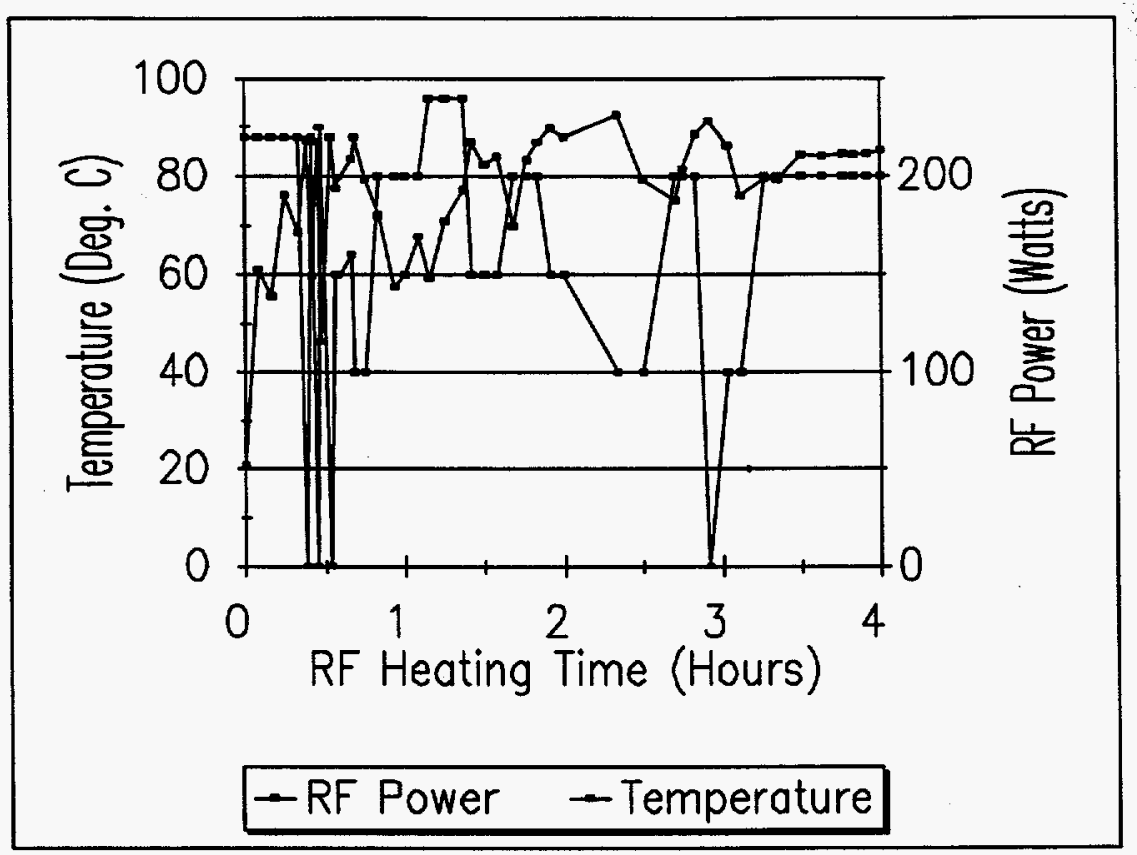

Figure 5.7 - Test 1: RF Power and Sample Temperature Data.

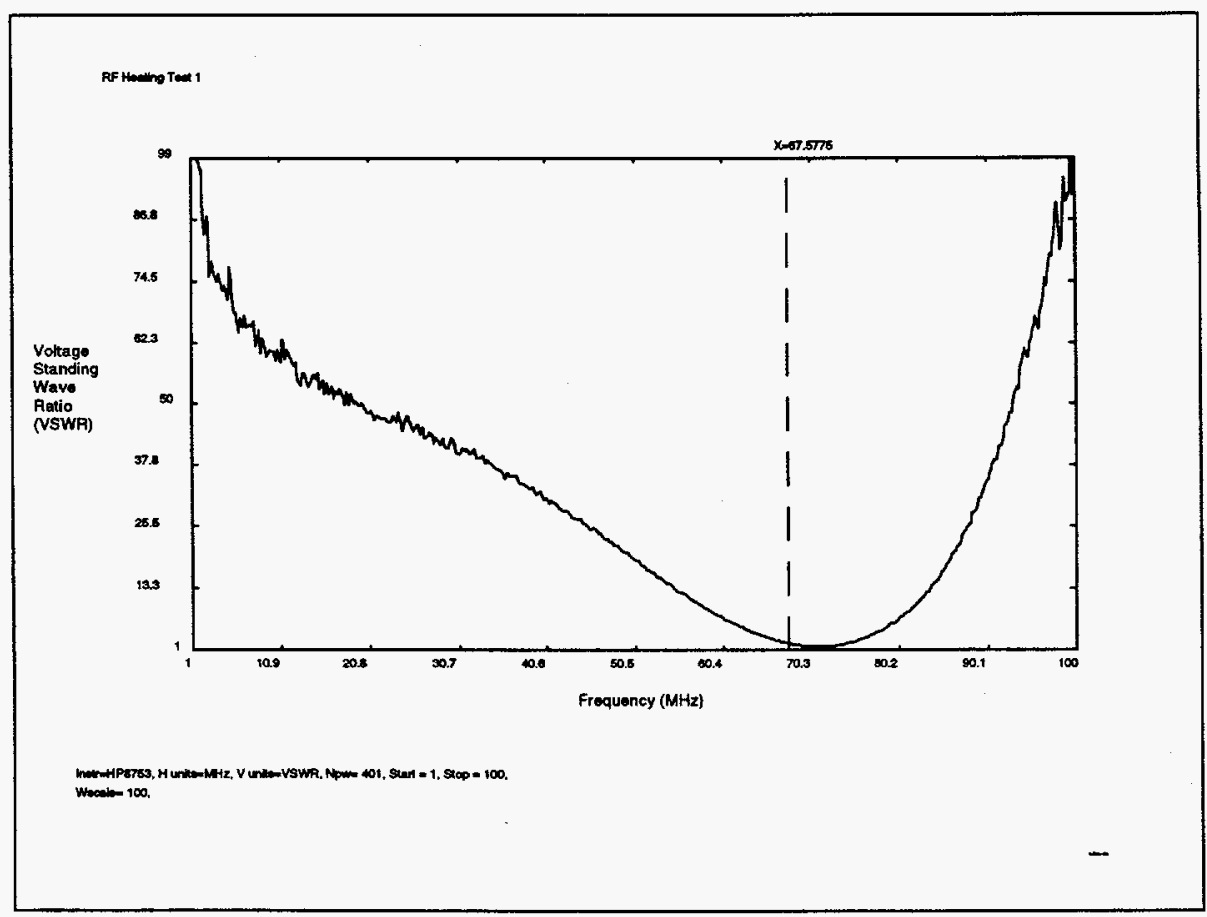

Figure 5.8 - Test 1: VSWR of the Laboratory RF Heating System 
range of 1 to $100 \mathrm{MHz}$. At $67.5775 \mathrm{MHz}$ using an impedance matching unit a VSWR of 1.04 was attained meaning that over $95 \%$ of the RF energy directed to the $\mathrm{RF}$ heating system was transmitted into the RF retort holding the silica suspension sample. During this test, 0.84 kilo watt hours of $\mathrm{RF}$ energy was delivered to the silica suspension sample. The estimated energy required was in the range of 0.05 to 0.5 kilo watt hours.

\section{Test 2 (Control)}

This test was used as a control, determining the amount of PCE removed without using RF heating. During this test the temperature of the laboratory was approximately $20^{\circ} \mathrm{C} .1400 \mathrm{cc}$ of silica suspension was loaded into the sample holder and $1.4 \mathrm{cc}$ of PCE (1000 ppmV) was added. Air sparging was applied for $20 \%$ of the time (2 minutes out of a 10-minute cycle). After 10 minutes an initial analytical sample was taken. The test was completed after 4 hours had elapsed.

The sample holder was hermetically sealed and allowed to reach equilibrium for two days at which time another sample was taken for analysis. The results of this test were a concentration of $112.085 \mathrm{ppmV}$ of PCE at the start of RF heating (after 10 minutes of using air sparging to mix the PCE) and a final concentration of $56.985 \mathrm{ppmV}$ after treatment with $\mathrm{RF}$ and air sparging. The air sparging was necessary to provide for the removal of the RF-heated contaminant (PCE) from the test sample.

\section{Test 3 (RF Heating)}

$1400 \mathrm{cc}$ of the silica suspension with $1.4 \mathrm{cc}$ PCE added was raised to the initial goal temperature of $90^{\circ} \mathrm{C}$ over a six-hour duration. This test used an average power of 220 watts at $69.805 \mathrm{MHz}$ (VSWR $=1.07$ before heating). An air sparging duty cycle was maintained at $10 \%$ ( 1 minute out of 10 minutes) for the first two hours of heating. After this period air sparging was curtailed to prevent the loss of heat. After 4.5 hours of RF heating, the goal temperature was attained and then maintained for the remaining 1.5 hours. During this test, $40 \mathrm{cc}$ analytical samples 
of the PCE-spiked ABCOV solution were removed at the start of testing and every half hour thereafter. At test completion, the sample holder containing the silica suspension was hermetically sealed and allowed to sit for over two days before it was analytically sampled. 1.26 kilo watt hours of $R F$ energy were delivered to the sample during this test.

Figure 5.9 shows the measured VSWR from 1 to $100 \mathrm{MHz}$ prior to Test 3, and Figure 5.10 shows the RF power delivered to the silica suspension sample and the sample's temperature.

\section{Test 4 (Repeat of Test 3)}

Figure 5.11 shows the temperature and RF power data, the goal temperature as in Test 3 was attained after 4.5 hours of heating. The RF power was cycled on and off after 5.25 hours of heating to maintain the goal temperature of $90^{\circ} \mathrm{C}$. A total of 1.2 kilo watt hour of RF energy was delivered to the sample.

A mass balance was conducted during this test. Initially there was $1400 \mathrm{cc}$ of the $A B C O V$ solution (at $1.05 \mathrm{gm} / \mathrm{cc}$ ). At the completion of testing $850 \mathrm{cc}$ remained. During the test, a total of $560 \mathrm{cc}$ was removed for analysis ( 14 samples at 40 $\mathrm{cc} /$ sample). Due to the volume measurement error (estimated at $\pm 3 \%$ ), the duration of the test, the amounts of the materials (1.4 cc of PCE), and the length of time the $\mathrm{ABCOV}$ solution sample was at or near boiling temperatures, no loss of PCE could be measured.

\subsection{DISCUSSION OF ANALYTICAL DATA}

$40 \mathrm{cc}$ samples were taken for analysis using EPA method 601 by American Environmental Laboratories (see Appendix A) during Test 2, Test 3, and Test 4. Inc. to determine the concentration of $\mathrm{PCE}$ in the silica suspension samples. For each of these tests $1.4 \mathrm{cc}$ of PCE had been added to the ABCOV solution sample. Because PCE (1.623 $\mathrm{gm} / \mathrm{cc})$ is denser than water $(1.0 \mathrm{gm} / \mathrm{cc})$ and is not miscible, it 


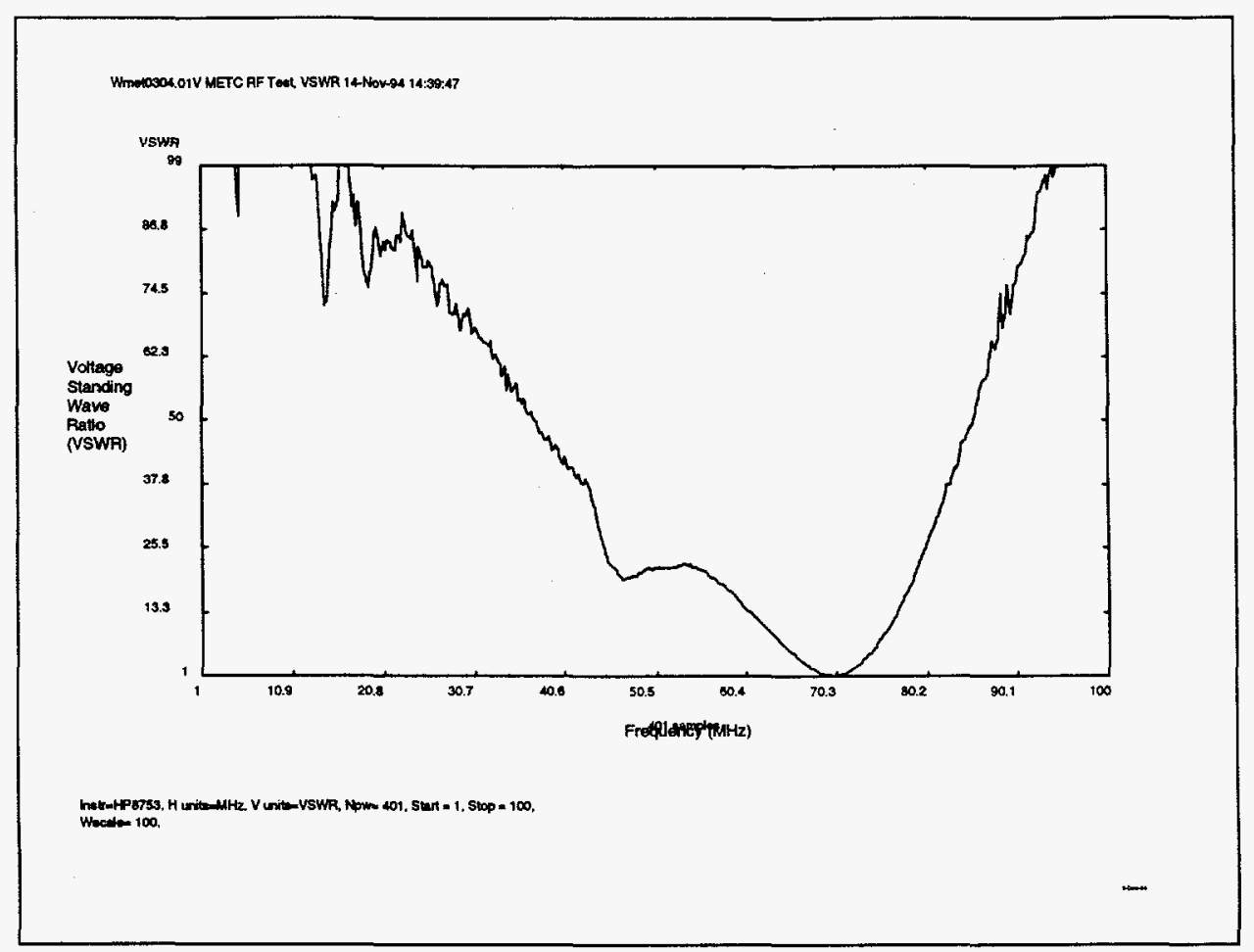

Figure 5.9 - Test 3: VSWR of Laboratory RF Heating System.

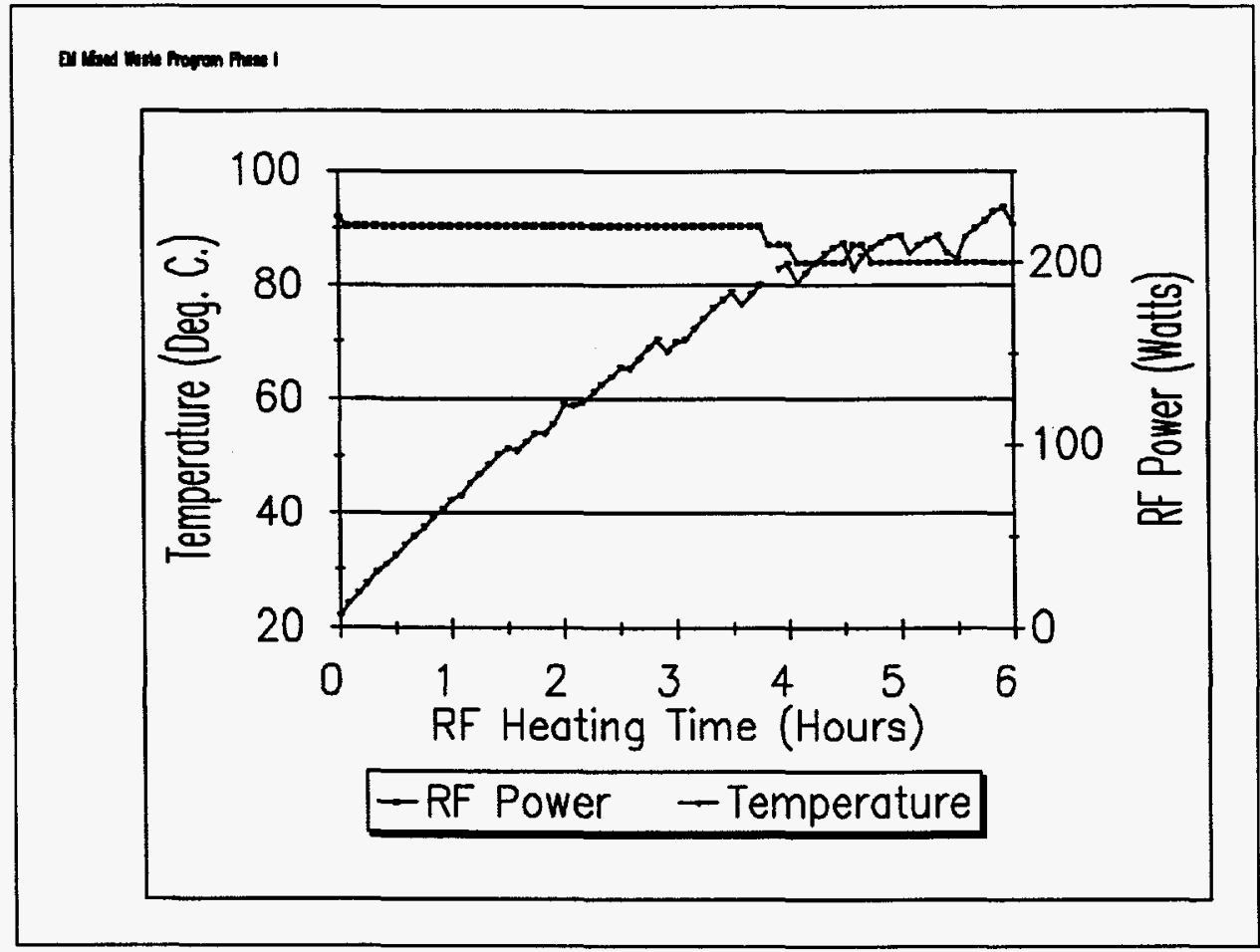

Figure 5.10 - Test 3: Sample Temperature and RF Power Data 


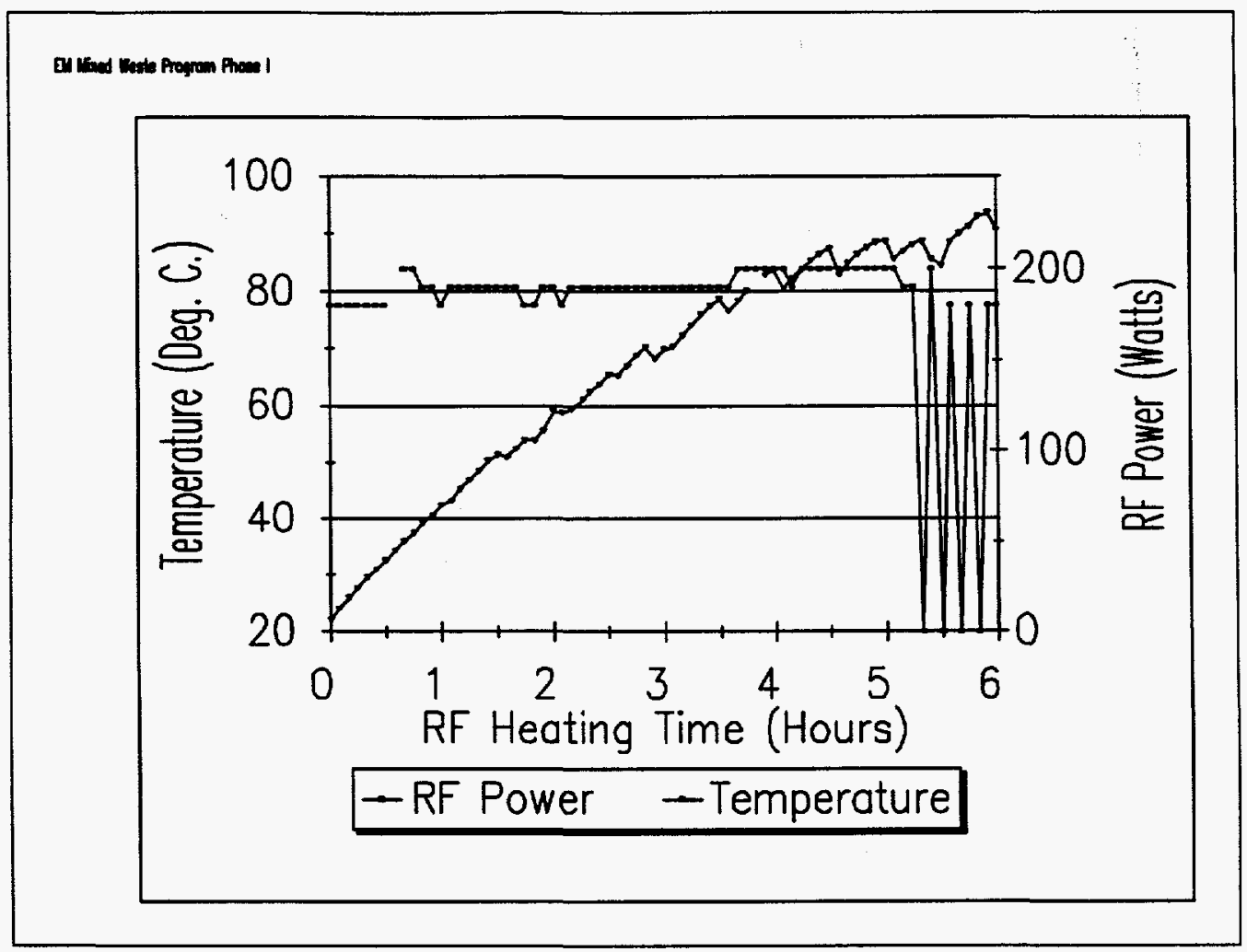

Figure 5.11 - Test 4: Sample Temperature and RF Power Data.

was concentrated at the bottom of the sample holder which is where the analytical samples were removed. Figures 5.12, 5.13, and 5.14 show the data from the RF heating tests: Test 3 and Test 4 . The PCE concentration data for Test 3 are presented as two curves because of a concentration change after 3 hours of heating. This increase in the concentration of PCE was caused by a sudden release of PCE from another liquid region of the sample holder. Similar behavior is also seen after one hour of heating in Test 4. The measured concentration at the start of RF heating is considerably less than $1000 \mathrm{ppmV}$ due to the effects of using air sparging to mix the PCE into the ABCOV solution.

Figure 5.15 shows highest concentration and final concentration of PCE in the ABCOV solution measured during Test 2, Test 3, and Test 4. This data was obtained from the analytical measurements using EPA method 601. This data 


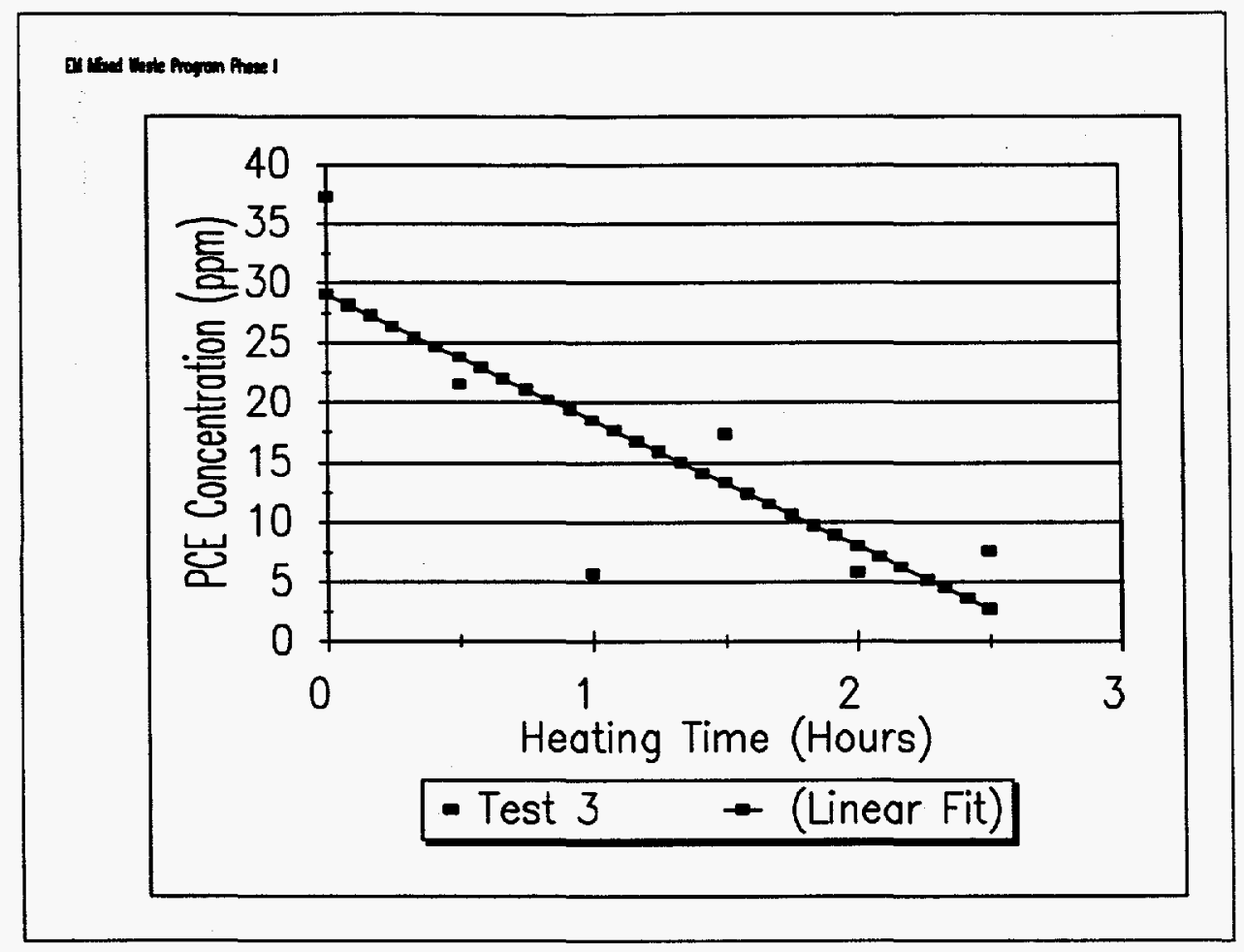

Figure 5.12 - Test 3: Concentration of PCE (Part 1).

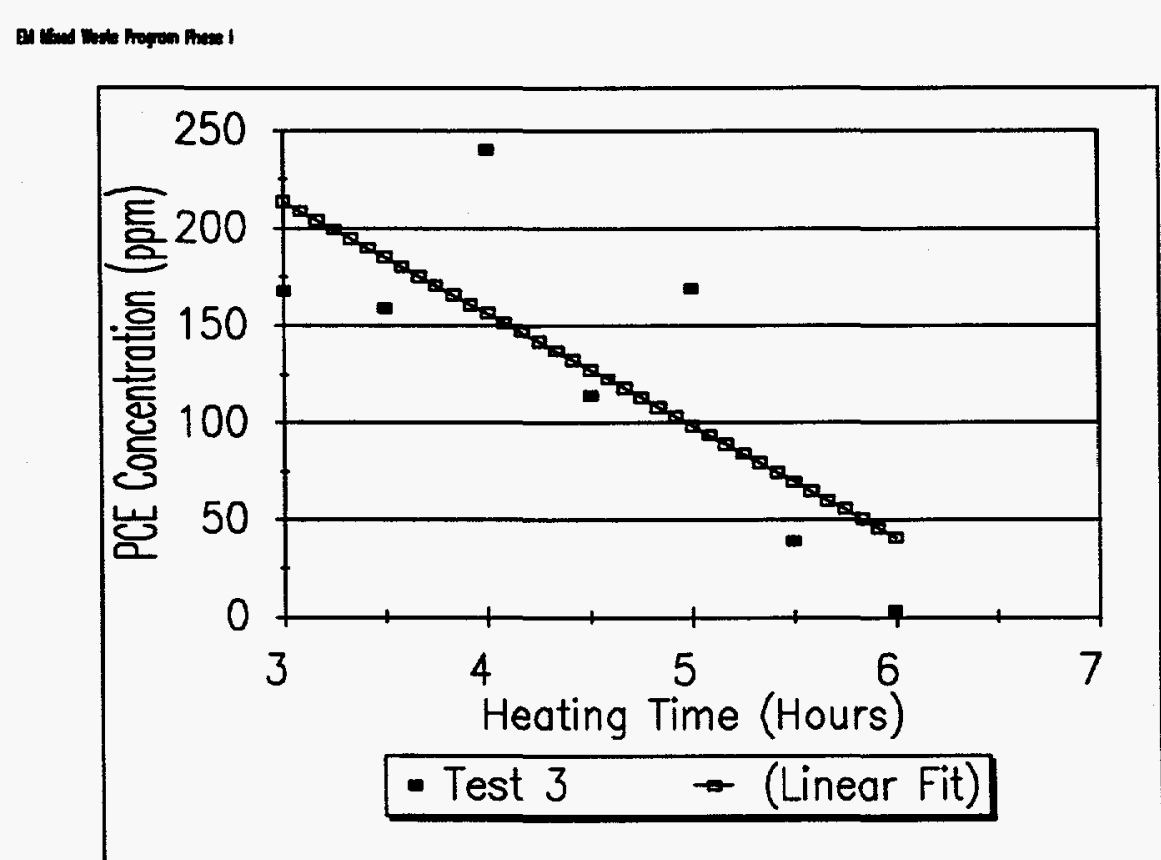

Figure 5.13 - Test 3: PCE Concentration (part 2) 


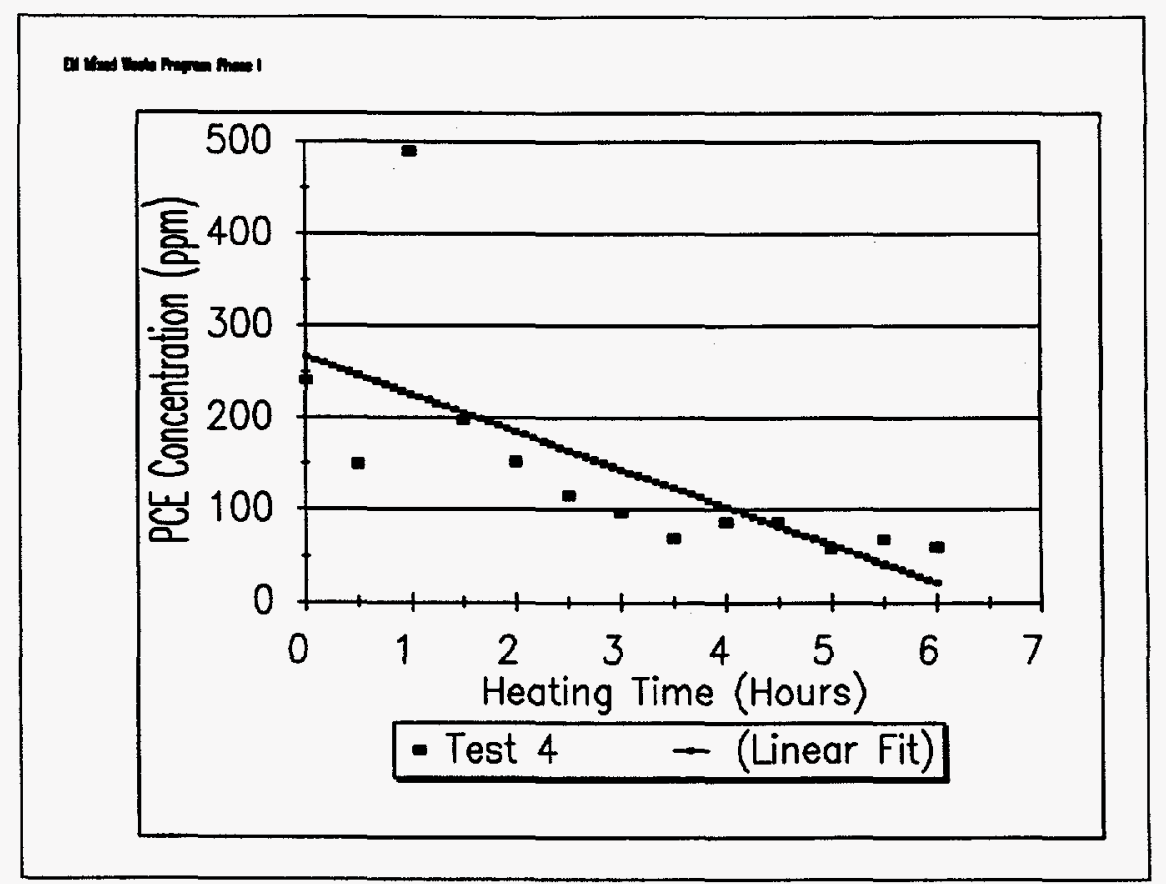

Figure 5.14 - Test 4: PCE Concentration.

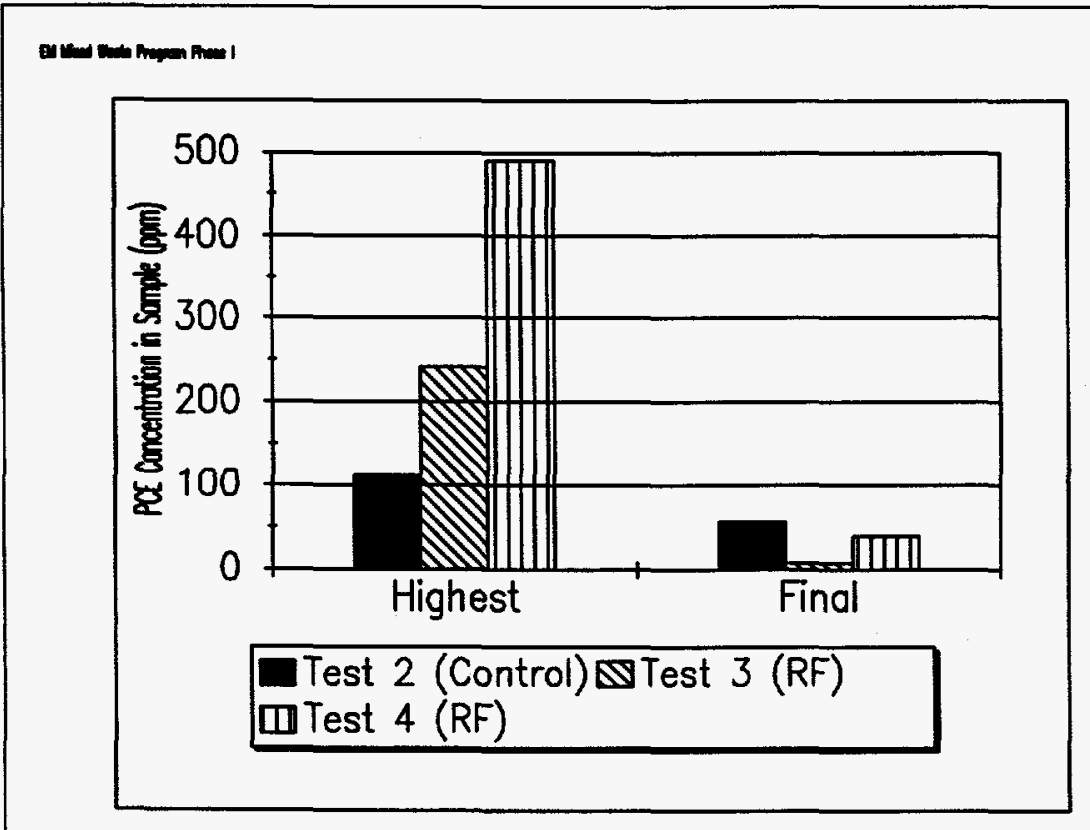

Figure 5.15 - Concentration of PCE in Silica Suspension Samples (based on analytical measurements performed by American Environmental Laboratories). 
shows a reduction in the concentration of $\mathrm{PCE}$ for all samples but a much greater reduction for the samples treated with $\mathrm{RF}$. This behavior is further exhibited in Figure 5.16 in which the reduction of PCE in the silica suspension samples is calculated. The control test (Test 2) yielded at $48 \%$ reduction, Test 3 resulted in a $96 \%$ reduction, and Test 4 in an 90\% reduction of the concentration of $P C E$ in the ABCOV solution. Furthermore, the RF heating data clearly indicate that still greater reduction in the concentration of PCE could be achieved by running the samples over a longer time period (more kilo watt hours).

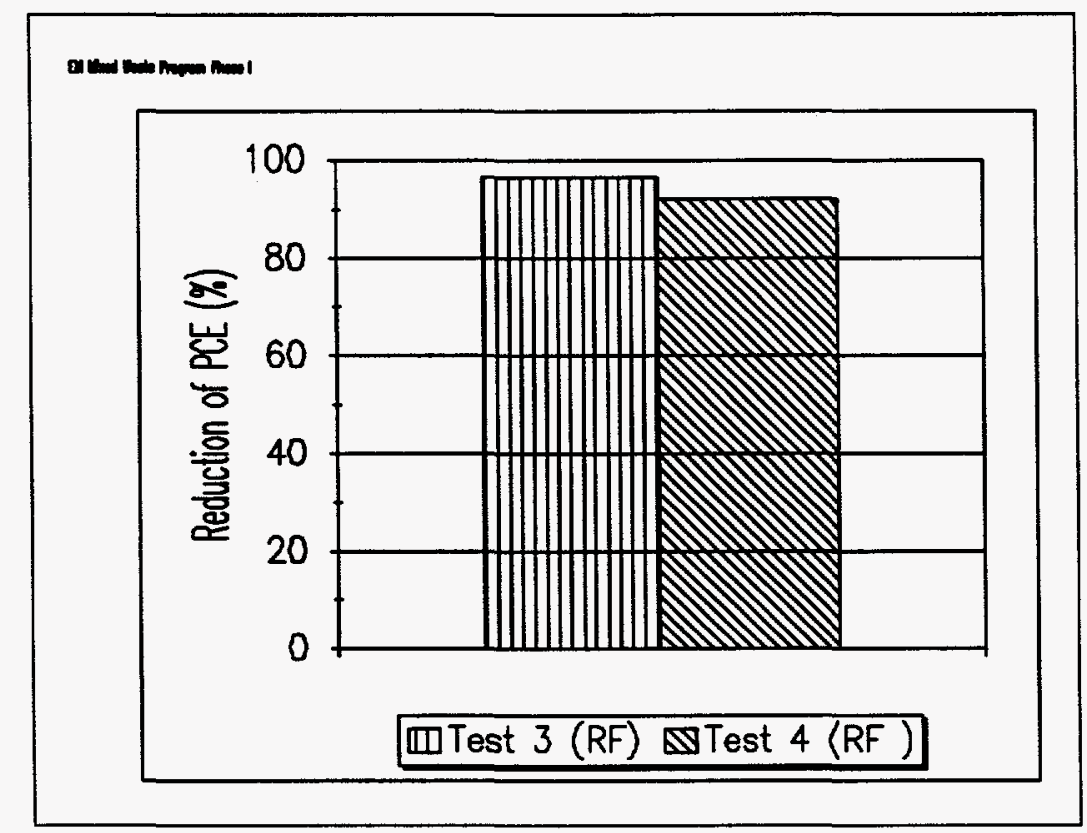

Figure 5.16 - PCE Reduction in PCE Spiked ABCOV Solution

\subsection{THEORETICAL MODELING OF THE LABORATORY RF HEATING PROCESS}

The theoretical electromagnetic environment (see Figure 5.17) was modeled for the laboratory tests using the measured dielectric properties for the ABCOV solution $\left(\varepsilon_{\mathrm{r}}=80\right.$ (water) and a conductivity of $13.5 \mathrm{~S} / \mathrm{m}$ ), the test frequency $(67 \mathrm{Mhz}$ ), the 8 inch long, 2 inch diameter monopole, and 200 watts of average RF power. 


\section{Electric Field Distribution in KAI Sample Holder Calculated by NEC-4}

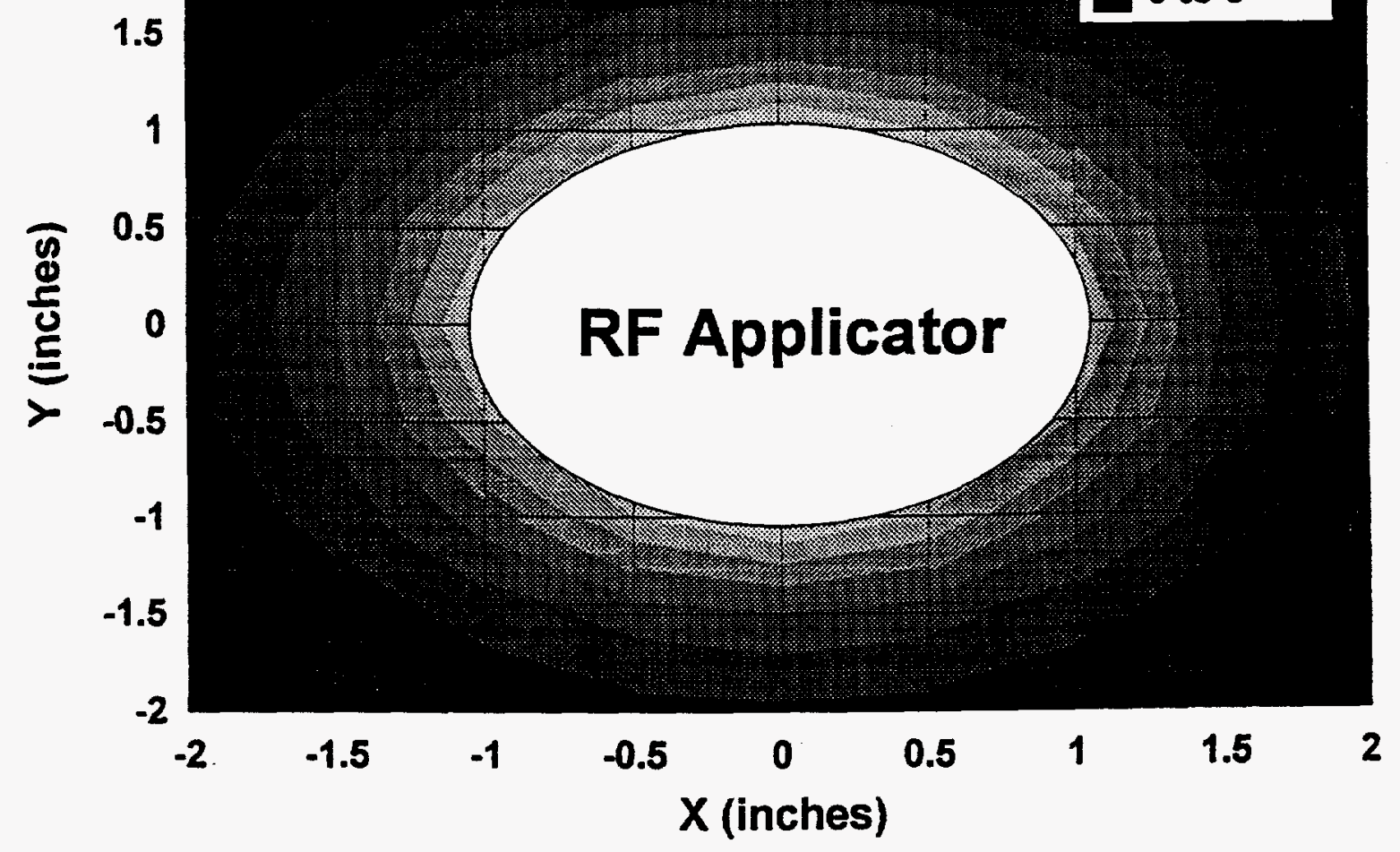

Figure 5.17 - Electric Field Distribution in KAI Sample Holder Calculated by NEC-4. 
During the RF heating tests a $20^{\circ} \mathrm{C} /$ hour heating rate was measured for the sample material at a position next to the applicator. Using the density of the ABCOV-C solution $(1.05 \mathrm{gm} / \mathrm{cc})$, the specific heat of $\mathrm{ABCOV}-\mathrm{C}\left(0.800 \mathrm{cal} / \mathrm{gm}-{ }^{\circ} \mathrm{C}\right)$, and the measured heating rate of the $\mathrm{ABCOV}$ solution, the rms (root-mean-square) electric field strength of $37.8 \mathrm{~V} / \mathrm{m}$ was calculated based on the solution of:

$$
\frac{\sigma|E|^{2}}{\rho c}=\frac{d T}{d t}
$$

Where: $\sigma$ is the conductivity in Siemens per meter, $\mathrm{E}$ is the electric field intensity in Volts per meter, $\rho$ is the density in $\mathrm{Kg}$ per cubic meter, $\mathrm{c}$ is the specific heat in $\mathrm{J} / \mathrm{Kg}-{ }^{\circ} \mathrm{C}$, and $\mathrm{dT} / \mathrm{dt}$ is the adiabatic heating rate in ${ }^{\circ} \mathrm{C}$ per second.

This value is in good agreement with the NEC-4 (Numerical Electromagnetics Code) data. The computer data generated by NEC is presented in Figure 5.17 which shows a theoretical field intensity next to the applicator surface of approximately 30 to 40 volts/meter.

\subsection{CONCLUSION}

Based on the "success" criteria established in the Laboratory-Scale Test Plan, the objectives of the bench scale testing of the RF organic process were achieved in that a near optimum treatment temperature was achieved for PCE and that the laboratory testing demonstrated that over $90 \%$ of an organic contaminant (PCE) could be removed for the silica suspension (converted ACM). During the test a heating rate of $20^{\circ} \mathrm{C} /$ hour was achieved for the silica suspension using 200 watts of RF power. This rate could be further increased using more power. These tests achieved significant removal of PCE operating near its boiling point of $121^{\circ} \mathrm{C}$. The electromagnetic energy required to accomplish the removal of the organic contaminant was quite reasonable at 1.2 kilo watt hours per kilo-gram of the silica suspension. The residence time can be significantly reduced by increasing the RF power level. For example, 30 minutes or less is a realistic goal for RF power levels in the 
range of 2 kilo watts. The total number of samples analyzed under EPA method 601 was 30 ( 2 samples from Test 2 (Control); 14 samples each for Test 3 and Test 4 ).

\subsection{COLD PLASMA DECOMPOSITION OF PCB SURROGATE FEASIBILITY STUDY}

Early experiments have shown that oxygen glow discharge plasmas are capable of oxidizing PCBs, removing chloride to form nontoxic species. Under the proper conditions (i.e., plasma operating parameters), the process can be tailored to produce $\mathrm{CO}_{2}$ and $\mathrm{HCl}$. The $\mathrm{HCl}$ can be neutralized, eliminating any hazardous products. It is also possible to form intermediate compounds that can be purified and reused as chemical feedstocks.

Variables that must be addressed include pressure, power, gas composition, residence time, and possibly catalysts. To examine these variables, a test bed reactor must be designed and operated, chemical analysis of the products must be conducted, and the process optimized. Because of the large number of variables, a statistical approach such as the Box-Benkein method must be used. In addition, the reactor design must be flexible enough to be easily reconfigured for the bench-scale system.

A PCB surrogate RF plasma destruction feasibility study was undertaken as an addition to the objectives described in the Phase $1 \mathrm{KAI}$ Test Plan. The PCB surrogate chosen was 1,2 - dichlorobenzene, and glass wool was chosen as a surrogate for asbestos. RF energy was used to both volatilize and begin decomposition of the PCB surrogate. The tests were performed for KAI by Dr. R. Allred of Adherent Technologies in Albuquerque, New Mexico. A Bronson Model PM-310 RF glow plasma discharge chamber operating at the ISM (Industrial, Scientific, Medicine) frequency of $13.56 \mathrm{MHz}$ was employed. The reactor vessel was small, $15 \mathrm{~cm}$ long $\mathrm{x}$ $10 \mathrm{~cm}$ in diameter, and the residence time was limited for these preliminary experiments, therefore limiting the extent of destruction possible for the dichlorobenzene. However, the key reactions leading to the fracture of the benzene ring were initiated in the first experiment. This was evidenced by the compounds detected by an inde- 
pendent laboratory evaluation of the products produced using the cold plasma (see Appendix B) (Assaigai Analytical Laboratory data). The initial reactions involve removal of hydrogen and chlorine obstruction from the dichlorobenzene creating free radicals.

These radicals can then combine with gas-phase radicals or lead to fracture of the aromatic ring. Decomposition of the rings (desired result) occurs by additional energy absorption from collisions with photons, ions, electrons, and excited atoms and molecules. The additional compounds collected or trapped provide evidence that these reactions are beginning to take place. Methyl benzene, phenol, and the tri, tetra, and hexachlorobenzene are a direct result of these types of reactions. A summary of analytical results is shown in Table 5.1. A second sample from the reactor vessel wall was analyzed by gas chromatography - mass spectroscopy and revealed no chlorocarbon or aromatic species present.

Table 5.1 — Summary of Analytical Results

Compound

2 Chlorophenol

1,3-dichlorobenzene

1,4-dichlorobenzene

1,2-dichlorobenzene

Hexachloroethane

1,2,4-trichlorobenzene

2,4-dichlorophenol

chlorobenzene

dichloromethylbenzenes

2,4-dichlorophenol tetrachloropropene 1,2-dichloro-4-(chloromethyl)

benzene
Concentration, ug/ml

Weight (\%)

74

26

76

720000

35

18000

32

97

309

21

14

15
0.01

0.004

0.01

97.5

0.005

2.4

0.005

0.013

0.042

0.003

0.002

0.002 


\subsection{REFERENCES}

1. Antennas in Matter, King, R.W.P., Smith, G.S., Massachusetts Institute of Technology, Cambridge, MA, 1981, pg. 741.

2. DNAPL Site Evaluation, Cohen, R.M., Mercer, J.W., CRC Press, Boca Raton, FL, 1993, Section 4.2. 


\section{TREATMENT OF ASBESTOS USING THE ABCOV METHOD}

\subsection{INTRODUCTION}

The ABCOV process was developed after years of extensive research at Battelle Laboratories and Georgia Tech. The process uses several chemical formulations to effectively improve the removal of asbestos-containing materials (ACM) and chemically convert asbestos into a non-hazardous substance, thus eliminating the "cradle-to-grave" liability. It offers the following advantages over conventional removal and disposal methods:

1. Time is reduced by applying the formulation ABCOV-T directly to the ACM, achieving improved wetting and initiating the conversion process. Some studies have documented removal times to be reduced by as much as $40 \%$, allowing for labor savings. In addition, after removal of ACM, ABCOV-T can be used to clean substrates off any remaining fibers, eliminating the need for scrubbing with wire brushes.

2. Depending on the type of filler material in the ACM, the volume of waste may be reduced by as much as $80 \%$. The removed ACM is immersed in a vat containing formulation ABCOV-C. After 30 or more minutes of agitation using a high-speed dispersion mixer, the mixture may be analyzed for the presence of asbestos fibers. Several previous demonstrations of the process by major utilities and federal institutions have confirmed conversion into a non-ACM substance.

3. Since a hazardous substance no longer exists, it becomes unnecessary to transport the remaining material to a required ACM landfill, leaving the owner with no cradle-to-grave liability.

4. The ABCOV-C which destroys the asbestos can be rejuvenated many times by adding ABCOV-R to the solution. This virtually eliminates any liquid waste from the process. 


\subsection{SCOPE OF WORK}

Ohio DSI Corp. (OHIO) performed a series of asbestos-destruction runs. The purpose of the runs was to demonstrate destruction, and to generate treated material for experimental operations by KAI Technologies, Inc. (KAI) and Westinghouse Science \& Technology Center. OHIO was tasked to initially analyze the ACM, wet it using ABCOV-T, and treat it using ABCOV-C. The resulting solution and solids were then provided to $\mathrm{KAI}$ and Westinghouse. OHIO was tasked to provide each contractor with 30 liters of solution resulting from the treatment of 4.1 kilograms of asbestos.

Specifically, OHIO performed the following activities:

1. Confirm asbestos content of test material

2. Perform asbestos-destruction runs using ABCOV-T and ABCOV-C

3. Provide converted ACM and spent ABCOV-C to Westinghouse and KAI

4. Provide a written report.

\subsection{MATERIALS AND METHODS}

OHIO used the following materials and methods to conduct the reduction of asbestos to a non-hazardous form using the ABCOV Method.

1. ACM was provided by Griffiss AFB. This material was pipe lagging. The material was pre-wet during removal by Griffiss AFB personnel with ABCOV-T, a wetting agent which is used in the field to assist in removal and to begin conversion of the ACM. Two samples of this material were dried to constant weight to determine the amount of ACM. A control material, which was wetted with water, was also dried.

2. ABCOV-C material was purchased from DSI Industries Consolidated, Inc. The material was received in a single 30 -gallon drum. The fluoride content of the initial material was measured and recorded.

3. ACM material was placed in plastic bags and weighed to the nearest 0.1 gram. The recipe used was to add 168 grams of material for each run in a KADY mill (high-shear mixer.)

4. Two liters (2000 $\mathrm{ml}$ to the nearest $10 \mathrm{ml}$ ) were then added to the mixer. The mixer was operated in all cases for 45 minutes. 
5. The final volume, $\mathrm{pH}$, and fluoride content of all samples were measured. A sample of the final material was collected for analysis of residual fibers.

6. All samples were analyzed by polarized light microscopy (PLM).

\subsection{RESULTS}

The results are provided in Table 6-1.

Table 6.1 - Results of the ABCOV-C Testing

\begin{tabular}{|c|c|c|c|c|c|c|c|c|c|}
\hline $\begin{array}{l}\text { Run } \\
\text { Number }\end{array}$ & $\begin{array}{l}\text { Wet ACM } \\
\text { Weight, } 8\end{array}$ & $\begin{array}{c}\mathrm{ABCOV} C \mathrm{C} \\
\mathrm{mi}\end{array}$ & $\begin{array}{l}\text { Initial } \\
\mathrm{F}-\%\end{array}$ & $\begin{array}{c}\text { Mixer } \\
\text { Haz }\end{array}$ & $\begin{array}{c}\text { Calculated } \\
\text { Mirer, } \\
\text { RPM }\end{array}$ & $\begin{array}{c}\text { Final } \\
\text { Volume, } \\
\text { mil }\end{array}$ & $\begin{array}{l}\text { Final } \\
\mathrm{F} \cdot 9 \%\end{array}$ & $\begin{array}{c}\text { Final } \\
\mathrm{pH}\end{array}$ & $\begin{array}{c}\text { ABCoV-R } \\
\text { Recha Esti- } \\
\text { mate, } \mathbf{g}\end{array}$ \\
\hline 1 & 168 & 2000 & 13.7 & 36.0 & 9508 & 1890 & 2.06 & 6.09 & 470 \\
\hline 2 & 168 & 2000 & 13.7 & 45.6 & 12388 & 1900 & 5.80 & 6.14 & 328 \\
\hline 3 & 168 & 2000 & 13.7 & 45.6 & 12388 & 1840 & 8.23 & 6.21 & 245 \\
\hline 4 & 168 & 2000 & 13.7 & 47.6 & 12931 & 1560 & 8.50 & 5.93 & 283 \\
\hline 5 & 168 & 2000 & 13.7 & 35.5 & 9644 & 2000 & 5.02 & 5.45 & 347 \\
\hline 6 & 168 & 2000 & 13.7 & 45.3 & 12307 & 1970 & 7.59 & 5.82 & 249 \\
\hline 7 & 168 & 2000 & 13.7 & 35.0 & 9508 & 1980 & 7.78 & 5.33 & 240 \\
\hline 8 & 168 & 2000 & 13.7 & 35.0 & 9508 & 1940 & 7.24 & 5.05 & 267 \\
\hline 9 & 168 & 2000 & 13.7 & 37.5 & 10188 & 1970 & 6.06 & 5.32 & 309 \\
\hline 10 & 168 & 2000 & 13.7 & 45.0 & 12225 & 1920 & 5.38 & 5.55 & 341 \\
\hline 11 & 168 & 2000 & 13.7 & 45.0 & 12225 & 2050 & 5.09 & 6.04 & 339 \\
\hline 12 & 168 & 2000 & 13.7 & 45.0 & 12225 & 1900 & 5.81 & 5.74 & 327 \\
\hline 13 & 168 & 2000 & 13.7 & 45.0 & 12225 & 2030 & 5.48 & 5.73 & 326 \\
\hline 14 & 168 & 2000 & 13.7 & 45.0 & 12225 & 2050 & 5.75 & 5.75 & 312 \\
\hline 15 & 168 & 2000 & 13.7 & 45.0 & 12225 & 1940 & 5.24 & 5.96 & 345 \\
\hline 16 & 168 & 2000 & 13.7 & 45.0 & 12225 & 1980 & 5.61 & 6.33 & 326 \\
\hline 17 & 168 & 2000 & 13.7 & 45.0 & 12225 & 1980 & 8.37 & 5.98 & 217 \\
\hline 18 & 168 & 2000 & 13.7 & 45.0 & 12225 & 1965 & 6.32 & 6.05 & 300 \\
\hline 19 & 168 & 2000 & 13.7 & 38.0 & 10323 & 1985 & 6.31 & 6.15 & 297 \\
\hline 20 & 168 & 2000 & 13.7 & 38.0 & 10323 & 1985 & 7.26 & 6.12 & 260 \\
\hline 21 & 168 & 2000 & 13.7 & 38.0 & 10323 & 1990 & 7.26 & 6.07 & 259 \\
\hline 22 & 168 & 2000 & 13.7 & 38.0 & 10323 & 1920 & 7.51 & 6.02 & 260 \\
\hline 23 & 168 & 2000 & 13.7 & 38.0 & 10323 & 1970 & 4.88 & 6.05 & 356 \\
\hline 24 & 168 & 2000 & 13.7 & 38.0 & 10323 & 1960 & 4.28 & 6.05 & 380 \\
\hline 25 & 168 & 2000 & 13.7 & 38.0 & 10323 & 1950 & 4.25 & 6.19 & 382 \\
\hline 26 & 168 & 2000 & 13.7 & 38.0 & 10323 & 2010 & 3.54 & 6.23 & 406 \\
\hline 27 & 168 & 2000 & 13.7 & 38.0 & 10323 & 2010 & 3.53 & 6.09 & 406 \\
\hline 28 & 168 & 2000 & 13.7 & 40.0 & 10867 & 2050 & 5.20 & 5.95 & 335 \\
\hline 29 & 168 & 2000 & 13.7 & 35.3 & 9590 & 2015 & 4.27 & 6.10 & 376 \\
\hline 30 & 168 & 2000 & 13.7 & 38.0 & 10323 & 2020 & 8.55 & 6.07 & 203 \\
\hline 31 & 168 & 2000 & 13.7 & 38.0 & 10323 & 2070 & 7.35 & 6.12 & 244 \\
\hline 32 & 168 & 2000 & 13.7 & 38.0 & 10323 & 2035 & 7.46 & 6.15 & 244 \\
\hline 33 & 168 & 2000 & 13.7 & 40.0 & 10867 & 2040 & 7.63 & 6.09 & 237 \\
\hline Average & & & & & & & & & 310 \\
\hline
\end{tabular}


The mixer was covered during the operation but the cover was not tight fitting. During operation of the mixer, there was both some small amount of splash and some vapor loss due to heating of the solution. The volume of solution added varied by approximately $10 \mathrm{ml}(0.5$ percent $)$. The final volume varied by about 5 percent, which is believed to be within experimental error.

During the first two minutes after adding solution to the asbestos, bubbling and foaming were noted. These both subsided after the first two minutes.

Two separate wet and dry weighings of pre-wetted ACM were made. In the first one, the initial and final weights indicated that the ABCOV-T wetting was approximately 15 percent of that sample. In the last one, done prior to Run 33 , the estimated $\mathrm{ABCOV}-\mathrm{T}$ wetting was approximately 53 percent. This indicates, as expected, that there was variability in ABCOV-T wetting of the material. The residual ABCOV-T is expected to affect both the final volume of the solution and the amount of make-up ABCOV- $R$ required. $A B C O V-R$ is used to rejuvenate spent $A B C O V-C$ to allow liquid recycling, thereby reducing process-waste quantities.

Particle size measurements were made by mixing the solution, filtering 250 $\mathrm{ml}$ aliquot of solution through a strainer and successive particle size filters using vacuum filtration, then drying and weighing to constant dryness. Based on these tests, the particle size estimate is provided in Table 6.2.

In all cases, conversion of the asbestos was complete in 45 minutes. No residual suspect fibers were identified by the microscopist.

Table 6.2 - Particle Size Estimate

\begin{tabular}{|c|c|c|c|c|c|}
\hline Paper: & $\begin{array}{l}\text { Particle Size } \\
\mu \mathrm{m}\end{array}$ & $\begin{array}{c}\text { Initial Wt. } \\
\text { grams }\end{array}$ & $\begin{array}{l}\text { Final Wt. } \\
\text { grams }\end{array}$ & Weight grams & $\begin{array}{l}\text { Weight Frac- } \\
\text { tion }\end{array}$ \\
\hline $1 / 32^{\prime \prime}$ & 794 & 97.40 & 99.12 & 1.72 & 0.14 \\
\hline $\mathrm{Q} 8$ & 10 & 1.96 & 7.37 & 5.41 & 0.43 \\
\hline 40 & 8 & 2.04 & 7.08 & 5.04 & 0.40 \\
\hline Q5 & 3.5 & 1.96 & 2.36 & 0.40 & 0.03 \\
\hline Total & & & & 12.57 & 1.00 \\
\hline
\end{tabular}


Asbestos analyses were performed on initial samples and the treated materials. Data are presented in Appendix C.

\subsection{CONCLUSIONS}

1. Thirty-three runs were made to treat ACM with ABCOV-C solution. In all 33 cases, the fibers were converted in 45 minutes.

2. The final fluoride content, final $\mathrm{pH}$, and final volume varied with each run.

3. The average amount of make-up ABCOV-R for each run was 310 grams, or 2.77 grams per gram of dry-weight asbestos (1.84 grams per gram of ABCOV-T-wetted material.)

4. Runs 1 through 32 were packaged into two containers.

a. Runs 1 through 16 were delivered to KAI in Woburn, MA on October 11, 1994.

b. Runs 17 through 32 were delivered to Westinghouse in Pittsburgh, PA on October 11, 1994. 


\section{INTERACTION WITH POTENTIAL USERS}

Since Phase 1 of this project only involves demonstrating the technical feasibility of the EM mixed waste processing system on a laboratory scale, and since all laboratory tests will be conducted in contractor facilities, very little interaction with potential users is expected. The primary contact with DOE facilities will be made to consult on the selection of ACM samples to be processed and the selection of surrogate materials for ion exchange, physical separation, and RF heating tests. Based on the recommendations of the COR, S. Bossart, representatives from DOE facilities at Oak Ridge, Hanford, and Fernald will be consulted to ensure the selection of appropriately representative ACM and surrogates. 


\section{PHASE 2 TECHNICAL APPROACH}

The Phase 2 technical approach will be based on the process sequence: organic removal - radioactive metals removal - ABCOV conversion - solidification. The approach differs with that taken in Phase 1 in that the ABCOV process will be employed after the waste streams have been generated. Selected samples of the waste stream (approximately two pounds of uranium-free, organic-free, ACM with insoluble lead compounds) will be sent by WSTC to Ohio DSI for ABCOV decomposition to validate the $A B C O V$ process. The decomposed samples will be sent back to WSTC for solidification.

The entirety of the radioactive metals removal from the ACM will take place at room temperature and ambient atmospheric pressure using ion exchange and electrochemical processing. Mechanical input for these processes is limited to mixing, milling, and pumping. Chemical conditions are mildly alkaline in the dissolution of uranium. The resulting product is uranium-free ACM containing insoluble lead compounds.

The RF system will be provided in modular form for bench-scale utilization at WSTC. The RF system will consist of a 55-gallon or smaller container with internal $\mathrm{RF}$ applicator for providing RF heating and contaminant destruction. The system will consist of RF generator, impedance matching network, plasma chamber, vacuum extraction system, and a condenser system for the organic reaction products.

\subsection{THE PHASE 2 SYSTEM}

The overall experimental system for study in Phase 2 will comprise these component systems, all placed on a laboratory bench at WSTC: 
1. The RF, organic-removal module;

2. The uranium-dissolution-and-removal module;

3. The receiving vessels for contaminated product streams.

\subsubsection{The RF, Organic-Removal Module}

The RF system requires processing of the contaminated ACM feed, volatilization and destruction of the organic contaminants followed by capture, and containment of the condensed contaminants. Contaminated ACM from a small source container will be fed into and through the $\mathrm{RF}$ volatilization chamber on a batch basis. The low-volume gas flow maintained through the chamber will convect volatilized organics into the contaminant-collection train. Organic-free ACM will be removed from the closed container for subsequent processing for the removal of uranium.

The contaminant-collection train will include a chilled condenser filled with fibrous packing, a carbon-promoted cartridge filter, and a large bed of carbon granules. Cleaned gas exiting the contaminant-collection train will be swept into a fumehood exhaust for fail-safe filtration in a HEPA core-filter and HEPA final filter.

\subsubsection{The Uranium-Dissolution-and-Removal Module}

Organic-free contaminated ACM removed from the RF module will be placed into a wet mill and be wetted with a slightly alkaline reagent solution that will solubilize anionic and cationic uranium compounds as well as un-ionized uranium oxide. The slurry of milled ACM and solubilized uranium will enter a low-shear mixer with addition of ion exchange resin. Residence time in the mixer will be between 30 and 60 minutes to assure equilibrium between the resin and solution. Effluent from the mixer will be pumped to a 30/60-mesh screen that will remove resin, but allow the milled ACM solids to pass through. ACM solids will be collected on a 
belt filter in the commercial process. In this bench work, ACM will be collected on a fabric or paper filter followed by rinsing with a dilute sulfuric acid spray to assure delivery of slightly acidic solids to the asbestos-conversion system.

Resin recovered from screening will be returned to the mixer by gravity underflow, exploiting the slough-flow property of the moist resin. A side-stream of resin will be purged periodically for regeneration in the electrochemical cell. The final product from the electrochemical cell will be assayed and characterized for disposal or uranium recovery.

Input materials to Uranium-Dissolution-And-Removal module will include:

- make-up alkaline reagent

- organic-free contaminated ACM from the RF, Organic-Removal module

- aqueous or anhydrous ammonia

- dilute sulfuric acid

- weak-acid anionic resin.

Product materials will include:

- wet uranium-free ACM solids containing insoluble lead compounds and dilute sulfuric acid

- uranium concentrate containing hydrochloric acid

- expended ion exchange resin.

All processing steps will be conducted on the same lot of ACM. 


\section{APPENDIX A}

KAI Bench-Scale Test Analytical Data 


\section{Explanation of EPA Method 601 Data}

Test 2 (Control Test)

Sample \#1 - taken after 10 minutes of agitation with $1000 \mathrm{ppmV}$ PCE added to ABCOV solution.

Sample \#2 - 48 hours later after conclusion of 4 hour test (holder was sealed after test).

Test 3 (RF Heating Test)

(Test 3.3)

Sample \#1 -

Sample \#2 -

Sample \#3 -

Sample \#4 -

Sample \#5 -

Sample \#6 -

Sample \#7 -

Sample \#8 -

Sample \#9 -

Sample \#10 -

Sample \#11 -

Sample \#12 -

Sample \#13 -

Sample \#14 -

Test 4 (RF Heating Test)

Sample \#1 -

Sample \#2 -

Sample \#3 -

Sample \#4 -

Sample \#5 -

Sample \#6 -

Sample \#7 -

Sample \#8 -

Sample \#9 -

Sample \#10 -

Sample \#11 -

Sample \#12 -

Sample \#13 -

Sample \#14 - start of RF heating after after 10 minutes of agitation with 1000 ppmV PCE added to ABCOV solution.

30 minutes after start of RF heating.

60 minutes after start of RF heating.

90 minutes after start of RF heating.

120 minutes after start of RF heating.

150 minutes after start of $\mathrm{RF}$ heating.

180 minutes after start of RF heating.

210 minutes after start of RF heating.

240 minutes after start of RF heating.

270 minutes after start of RF heating.

300 minutes after start of RF heating.

330 minutes after start of RF heating.

360 minutes after start of RF heating (end of RF heating, holder closed).

48 hours after start of RF heating.

start of RF heating after after 10 minutes of agitation with 1000 ppmV PCE added to ABCOV solution.

30 minutes after start of RF heating.

60 minutes after start of RF heating.

90 minutes after start of RF heating.

120 minutes after start of RF heating.

150 minutes after start of RF heating.

180 minutes after start of RF heating.

210 minutes after start of RF heating.

240 minutes after start of RF heating.

270 minutes after start of RF heating.

300 minutes after start of RF heating.

330 minutes after start of RF heating.

360 minutes after start of RF heating (end of RF heating, holder closed).

71 hours after start of RF heating. 


\begin{tabular}{||llll||}
\hline TO: KAI Technologies, Inc. & DATE RECEIVED & 11/09/94 \\
175 N. New Boston St. & DATE COLLECTED & $11 / 07 / 94$ \\
Woburn, MA 01801 & COLLECTED BY & STEVE PRICE \\
ATTN: Steven Price & MATRIX & : Wastewater \\
PO/ID NUMBER : $94-75$ & AA52122 & & \\
SAMPLE DESCRIPTION: Test \#2 Sample \#1 & & \\
\hline
\end{tabular}

- ANALYTICAL RESULTS -

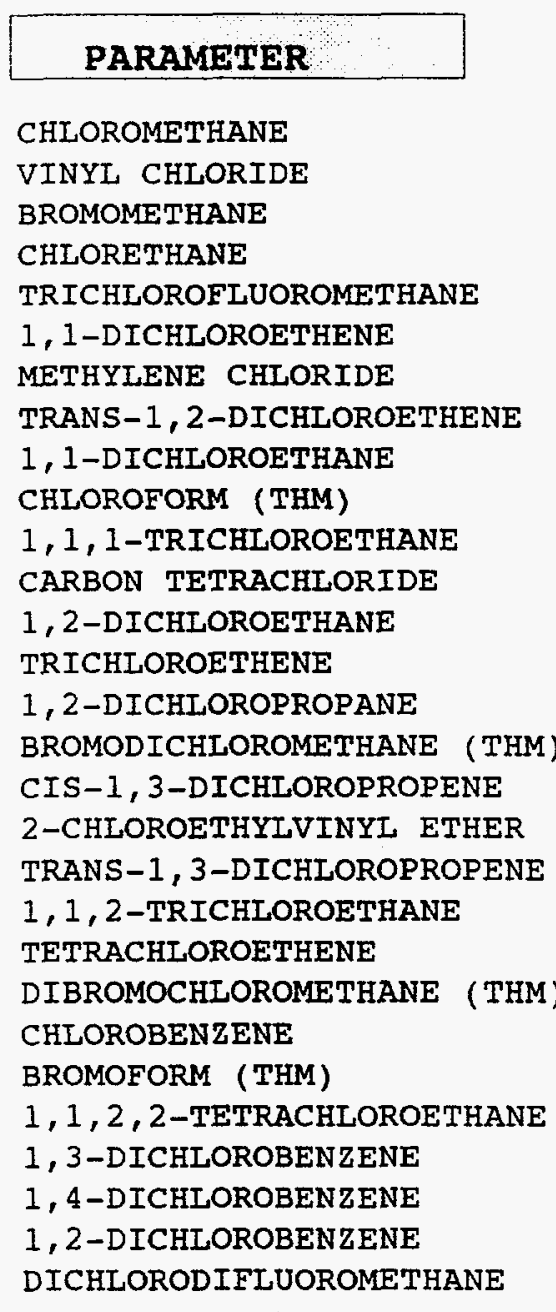
1,4-Dichlorobutane

\section{SAMPLE DILUTION: 5 TIMES
PERCENT SURROGATE RECOVERY: \\ SAMPLE DILUTION: 5 TIMES
PERCENT SURROGATE RECOVERY:}

\begin{tabular}{|c|c|}
\hline RESULT & UOM \\
\hline ND & UG/L \\
\hline ND & UG /L \\
\hline ND & UG /L \\
\hline ND & UG/L \\
\hline ND & UG/L \\
\hline ND & UG/L \\
\hline ND & UG/L \\
\hline ND & UG/L \\
\hline ND & UG/L \\
\hline ND & UG/L \\
\hline ND & $\mathrm{UG} / \mathrm{L}$ \\
\hline ND & UG/L \\
\hline ND & $\mathrm{UG} / \mathrm{L}$ \\
\hline ND & $\mathrm{UG} / \mathrm{L}$ \\
\hline ND & UG/L \\
\hline ND & UG/L \\
\hline ND & UG / L \\
\hline ND & UG / L \\
\hline ND & UG /L \\
\hline ND & UG/L \\
\hline 112,085 & UG /L \\
\hline ND & UG/L \\
\hline ND & UG/L \\
\hline 21.5 & UG/L \\
\hline ND & $\mathrm{UG} / \mathrm{L}$ \\
\hline ND & UG/L \\
\hline ND & $\mathrm{UG} / \mathrm{L}$ \\
\hline ND & $\mathrm{UG} / \mathrm{L}$ \\
\hline ND & UG/L \\
\hline
\end{tabular}

\section{TEST DATE}
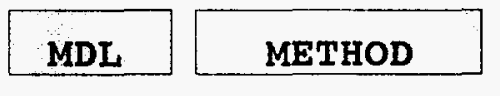

$11 / 16 / 94$

1.0

EPA 601

$11 / 16 / 94$

$11 / 16 / 94$

$11 / 16 / 94$

$11 / 16 / 94$

$11 / 16 / 94$

$11 / 16 / 94$

$11 / 16 / 94$

$11 / 16 / 94$

$11 / 16 / 94$

$11 / 16 / 94$

$11 / 16 / 94$

$11 / 16 / 94$

$11 / 16 / 94$

$11 / 16 / 94$

$11 / 16 / 94$

$11 / 16 / 94$

$11 / 16 / 94$

$11 / 16 / 94$

$11 / 16 / 94$

$11 / 16 / 94$

$11 / 16 / 94$

$11 / 16 / 94$

$11 / 16 / 94$

$11 / 16 / 94$

$11 / 16 / 94$

$11 / 16 / 94$

$11 / 16 / 94$

$11 / 16 / 94$

1.0

1.0

1.0

1.0

1.0

1.0

1.0

1.0

1.0

1.0

1.0

1.0

1.0

1.0

1.0

1.0

1.0

1.0

1.0

1.0

1.0

1.0

1.0

1.0

1.0

1.0

1.0

1.0
EPA 601

EPA 601

EPA 601

EPA 601

EPA 601

EPA 601

EPA 601

EPA 601

EPA 601

EPA 601

EPA 601

EPA 601

EPA 601

EPA 601

EPA 601

EPA 601

EPA 601

EPA 601

EPA 601

EPA 601

EPA 601

EPA 601

EPA 601

EPA 601

EPA 601

EPA 601

EPA 601

EPA 601 sampling technique and to the actual sample as tested. The integrity of results is dependent upon the quality of the dilution factors, if any. American Environmental Laboratories, Inc. shall not be held liable for any interpretation of analytical resuits. 


\begin{tabular}{|c|c|c|}
\hline $\begin{array}{l}\text { TO: KAI Technologies, Inc. } \\
175 \text { N. New Boston st. } \\
\text { Woburn, MA } 01801 \\
\text { ATTN: steven Price }\end{array}$ & $\begin{array}{l}\text { DATE RECEIVED } \\
\text { DATE COLLECTED } \\
\text { COLLECTED BY } \\
\text { MATRIX }\end{array}$ & $\begin{aligned} &: 11 / 10 / 94 \\
& 11 / 09 / 94 \\
&: \text { SAME } \\
&: \text { Wastewater }\end{aligned}$ \\
\hline $\begin{array}{lc}\text { PO/ID NUMBER : } & \text { AA52192 } \\
\text { SAMPLE DESCRIPTION : } & \text { Test } \# \mathbb{R}-\text { Sample } \# 2\end{array}$ & & \\
\hline
\end{tabular}

\section{PARAMETER}

CHLOROMETHANE

VINYL CHLORIDE

BROMOMETHANE

CHLORETHANE

TRICHLOROFLUOROMETHANE

1,1-DICHLOROETHENE

METHYLENE CHLORIDE

TRANS-1, 2-DICHLOROETHENE

1,1 -DICHLOROETHANE

CHLOROFORM (THM)

1, 1, 1-TRICHLOROETHANE

CARBON TETRACHLORIDE

1,2-DICHLOROETHANE

TRICHLOROETHENE

1,2-DICHLOROPROPANE

BROMODICHLOROMETHANE (THM)

CIS-1,3-DICHLOROPROPENE

2-CHLOROETHYLVINYL ETHER

TRANS-1, 3-DICHLOROPROPENE

$1,1,2$-TRICHLOROETHANE

TETRACHLOROETHENE

DIBROMOCHLOROMETHANE (THM)

CHLOROBENZENE

BROMOFORM (THM)

$1,1,2,2$-TETRACHLOROETHANE

1,3-DICHLOROBENZENE

1,4-DICHLOROBENZENE

1,2-DICHLOROBENZENE

DICHLORODIFLUOROMETHANE

SAMPLE DILUTION: 5 TIMES PERCENT SURROGATE RECOVERY:

1,4-Dichlorobutane
- ANALYTICAL RESULTS -

\begin{tabular}{|c|c|c|c|c|}
\hline RESULT & UOM & TEST DATE & MDL & METHOD \\
\hline ND & $\mathrm{UG} / \mathrm{L}$ & $11 / 16 / 94$ & 1.0 & EPA 601 \\
\hline ND & $\mathrm{UG} / \mathrm{L}$ & $11 / 16 / 94$ & 1.0 & EPA 601 \\
\hline ND & $\mathrm{UG} / \mathrm{L}$ & $11 / 16 / 94$ & 1.0 & EPA 601 \\
\hline ND & $\mathrm{UG} / \mathrm{L}$ & $11 / 16 / 94$ & 1.0 & EPA 601 \\
\hline ND & $\mathrm{UG} / \mathrm{L}$ & $11 / 16 / 94$ & 1.0 & EPA 601 \\
\hline ND & $\mathrm{UG} / \mathrm{L}$ & $11 / 16 / 94$ & 1.0 & EPA 601 \\
\hline ND & $\mathrm{UG} / \mathrm{L}$ & $11 / 16 / 94$ & 1.0 & EPA 601 \\
\hline ND & UG/I & $11 / 16 / 94$ & 1.0 & EPA 601 \\
\hline ND & UG/L & $11 / 16 / 94$ & 1.0 & EPA 601 \\
\hline ND & $U G / L$ & $11 / 16 / 94$ & 1.0 & EPA 601 \\
\hline 264 & $\mathrm{UG} / \mathrm{L}$ & $11 / 16 / 94$ & 1.0 & EPA 601 \\
\hline ND & $\mathrm{UG} / \mathrm{I}$ & $11 / 16 / 94$ & 1.0 & EPA 601 \\
\hline ND & $\mathrm{UG} / \mathrm{L}$ & $11 / 16 / 94$ & 1.0 & EPA 601 \\
\hline ND & $\mathrm{UG} / \mathrm{L}$ & $11 / 16 / 94$ & 1.0 & EPA 601 \\
\hline ND & $\mathrm{UG} / \mathrm{I}$ & $11 / 16 / 94$ & 1.0 & EPA 601 \\
\hline ND & $\mathrm{UG} / \mathrm{L}$ & $11 / 16 / 94$ & 1.0 & EPA 601 \\
\hline ND & $\mathrm{UG} / \mathrm{L}$ & $11 / 16 / 94$ & 1.0 & EPA 601 \\
\hline ND & $U G / L$ & $11 / 16 / 94$ & 1.0 & EPA 601 \\
\hline ND & UG/L & $11 / 16 / 94$ & 1.0 & EPA 601 \\
\hline ND & $\mathrm{UG} / \mathrm{I}$ & $11 / 16 / 94$ & 1.0 & EPA 601 \\
\hline 56,985 & $U G / I$ & $11 / 16 / 94$ & 1.0 & EPA 601 \\
\hline ND & $U G / I$ & $11 / 16 / 94$ & 1.0 & EPA 601 \\
\hline ND & $\mathrm{UG} / \mathrm{L}$ & $11 / 16 / 94$ & 1.0 & EPA 601 \\
\hline 21.5 & $\mathrm{UG} / \mathrm{I}$ & $11 / 16 / 94$ & 1.0 & EPA 601 \\
\hline ND & $\mathrm{UG} / \mathrm{L}$ & $11 / 16 / 94$ & 1.0 & EPA 601 \\
\hline ND & UG/L & $11 / 16 / 94$ & 1.0 & EPA 601 \\
\hline ND & $\mathrm{UG} / \mathrm{L}$ & $11 / 16 / 94$ & 1.0 & EPA 601 \\
\hline ND & $\mathrm{UG} / \mathrm{L}$ & $11 / 16 / 94$ & 1.0 & EPA 601 \\
\hline ND & $\mathrm{UG} / \mathrm{L}$ & $11 / 16 / 94$ & 1.0 & EPA 601 \\
\hline
\end{tabular}

These results apply only to the actual sample as tested. The integrity of results is dependent upon the quality of the sampling technique and subsequent handling. Actual detection limits are the above reported MDL's multiplied by dilution factors, if any. American Environmental Laboratories, Inc. shall not be held liable for any interpretation of analytical results. 


\begin{tabular}{|cll|}
\hline TO: KAI Technologies, InC. & DATE RECEIVED & $: 11 / 17 / 94$ \\
$175 \mathrm{~N}$. New Boston St. & DATE COLLECTED & $11 / 15 / 94$ \\
WOburn, MA 01801 & COLLECTED BY & : STEVE PRICE \\
ATTN: Steven Price & MATRIX & : Water \\
PO/ID NUMBER : & AA52620 & \\
SAMPLE DESCRIPTION : Test 3.3, Sample \#1 & \\
\hline
\end{tabular}

- ANALYTICAL RESULTS -

\section{PARAMETER}

CHLOROMETHANE

VINYL CHLORIDE

BROMOMETHANE

CHLORETHANE

TRICHLOROFLUOROMETHANE

1, 1-DICHLOROETHENE

METHYIENE CHLORIDE

TRANS-1, 2-DICHLOROETHENE

1,1-DICHLOROETHANE

CHLOROFORM (THM)

$1,1,1$-TRICHLOROETHANE

CARBON TETRACHLORIDE

1, 2-DICHLOROETHANE

TRICHLOROETHENE

1,2-DICHLOROPROPANE

BROMODICHLOROMETHANE (THM)

CIS-1,3-DICHLOROPROPENE

2-CHLOROETHYIVINYL ETHER

TRANS-1, 3-DICHLOROPROPENE

$1,1,2$-TRICHLOROETHANE

TETRACHLOROETHENE

DIBROMOCHLOROMETHANE (THM)

CHLOROBENZENE

BROMOFORM (THM)

$1,1,2,2$-TETRACHLOROETHANE

1, 3-DICHLOROBENZENE

1,4-DICHLOROBENZENE

1,2-DICHLOROBENZENE

DICHLORODIFLUOROMETHANE

DILUTION FACTOR: 5 TIMES

PERCENT SURROGATE RECOVERY:

1,4-Dichlorobutane

\begin{tabular}{ll}
\hline RESULT & UOM \\
\cline { 2 - 2 } ND & UG/L \\
ND & UG/L \\
ND & UG/L \\
ND & UG/L \\
ND & UG/L \\
ND & UG/L \\
ND & UG/L \\
ND & UG/L \\
ND & UG/L \\
ND & UG/L \\
ND & UG/L \\
ND & UG/L \\
ND & UG/L \\
ND & UG/L \\
ND & UG/L \\
ND & UG/L \\
ND & UG/L \\
ND & UG/L \\
ND & UG/L \\
27.0 & UG/L \\
37 , 315 & UG/L \\
ND & UG/L \\
ND & UG/L \\
ND & UG/L \\
ND & UG/L \\
ND & UG/L \\
ND & UG/L \\
ND & UG/L \\
ND & UG/L \\
&
\end{tabular}

1148

\section{TEST DATE}

$11 / 22 / 94$

$11 / 22 / 94$

$11 / 22 / 94$

$11 / 22 / 94$

$11 / 22 / 94$

$11 / 22 / 94$

$11 / 22 / 94$

$11 / 22 / 94$

$11 / 22 / 94$

$11 / 22 / 94$

$11 / 22 / 94$

$11 / 22 / 94$

$11 / 22 / 94$

$11 / 22 / 94$

$11 / 22 / 94$

$11 / 22 / 94$

$11 / 22 / 94$

$11 / 22 / 94$

$11 / 22 / 94$

$11 / 22 / 94$

$11 / 22 / 94$

$11 / 22 / 94$

$11 / 22 / 94$

$11 / 22 / 94$

$11 / 22 / 94$

$11 / 22 / 94$

$11 / 22 / 94$

$11 / 22 / 94$

$11 / 22 / 94$

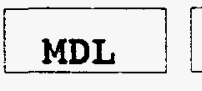

1.0

1.0

1.0

1.0

1.0

1.0

1.0

1.0

1.0

1.0

1.0

1.0

1.0

1.0

1.0

1.0

1.0

1.0

1.0

1.0

1.0

1.0

1.0

1.0

1.0

1.0

1.0

1.0

1.0

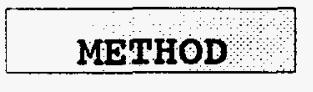

EPA 601

EPA 601

EPA 601

EPA 601

EPA 601

EPA 601

EPA 601

EPA 601

EPA 601

EPA 601

EPA 601

EPA 601

EPA 601

EPA 601

EPA 601

EPA 601

EPA 601

EPA 601

EPA 601

EPA 601

EPA 601

EPA 601

EPA 601

EPA 601

EPA 601

EPA 601

EPA 601

EPA 601

EPA 601

\footnotetext{
These results apply only to the actual sample as tested. The integrity of results is dependent upon the quality of the sampling technique and subsequent handling. Actual detection limits are the above reported MDL's multiplied by dilution factors, if any. American Environmental Laboratories, Inc. shall not be held liable for any interpretation of analytical results.
} 
To: KAI Technologies, Inc.

175 N. New Boston st.

Woburn, MA 01801

ATTN: Steven Price

PO/ID NUMBER : $94-75$

AA52758

$\begin{array}{ll}\text { DATE RECEIVED } & : 11 / 21 / 94 \\ \text { DATE COLLECTED } & 11 / 15 / 94 \\ \text { COLLECTED BY } & : \text { SAME } \\ \text { MATRIX } & : \text { Water }\end{array}$

COLLECTED BY : SAME

MATRIX

: Water

SAMPLE DESCRIPTION: Test 3.3 - Sample 2

\begin{tabular}{|c|c|c|c|c|c|}
\hline PARAMETER & RESULT & UOM & TEST DATE & MDL & \\
\hline CHLOROMETHANE & ND & UG/L & $11 / 22 / 94$ & 1.0 & \\
\hline VINYI CHLORIDE & ND & UG/L & $11 / 22 / 94$ & 1.0 & \\
\hline BROMOMETHANE & ND & UG/I & $11 / 22 / 94$ & 1.0 & \\
\hline CHLORETHANE & ND & UG/I & $11 / 22 / 94$ & 1.0 & \\
\hline TRICHLOROFLUOROMETHANE & ND & UG/L & $11 / 22 / 94$ & 1.0 & \\
\hline 1, 1-DICHLOROETHENE & ND & $\mathrm{UG} / \mathrm{L}$ & $11 / 22 / 94$ & 1.0 & \\
\hline METHYLENE CHLORIDE & ND & UG/L & $11 / 22 / 94$ & 1.0 & \\
\hline TRANS-1,2-DICHLOROETHENE & ND & UG/I & $11 / 22 / 94$ & 1.0 & \\
\hline 1, 1-DICHLOROETHANE & ND & $U G / I$ & $11 / 22 / 94$ & 1.0 & \\
\hline CHLOROFORM (THM) & ND & $\mathrm{UG} / \mathrm{I}$ & $11 / 22 / 94$ & 1.0 & \\
\hline $1,1,1$-TRICHLOROETHANE & ND & UG/L & $11 / 22 / 94$ & 1.0 & \\
\hline CARBON TETRACHLORIDE & ND & UG/L & $11 / 22 / 94$ & 1.0 & \\
\hline 1,2-DICHLOROETHANE & ND & UG/L & $11 / 22 / 94$ & 1.0 & \\
\hline TRICHLOROETHENE & ND & $\mathrm{UG} / \mathrm{L}$ & $11 / 22 / 94$ & 1.0 & \\
\hline 1,2-DICHLOROPROPANE & ND & UG/L & $11 / 22 / 94$ & 1.0 & \\
\hline BROMODICHLOROMETHANE (THM) & ND & UG/L & $11 / 22 / 94$ & 1.0 & \\
\hline CIS-1,3-DICHLOROPROPENE & ND & UG/L & $11 / 22 / 94$ & 1.0 & \\
\hline 2-CHLOROETHYLVINYL ETHER & ND & UG/L & $11 / 22 / 94$ & 1.0 & \\
\hline TRANS-1,3-DICHLOROPROPENE & ND & UG/L & $11 / 22 / 94$ & 1.0 & \\
\hline $1,1,2$-TRICHLOROETHANE & ND & UG/I & $11 / 22 / 94$ & 1.0 & \\
\hline TETRACHLOROETHENE & 21,595 & UG/L & $11 / 22 / 94$ & 1.0 & \\
\hline DIBROMOCHLOROMETHANE (THM) & ND & UG/I & $11 / 22 / 94$ & 1.0 & \\
\hline CHLOROBENZENE & ND & UG/L & $11 / 22 / 94$ & 1.0 & \\
\hline BROMOFORM ( THM) & ND & UG/I & $11 / 22 / 94$ & 1.0 & \\
\hline $1,1,2,2$-TETRACHLOROETHANE & ND & $\mathrm{UG} / \mathrm{L}$ & $11 / 22 / 94$ & 1.0 & \\
\hline 1,3-DICHLOROBENZENE & ND & UG/I & $11 / 22 / 94$ & 1.0 & \\
\hline 1,4-DICHLOROBENZENE & ND & UG/I & $11 / 22 / 94$ & 1.0 & \\
\hline 1,2-DICHLOROBENZENE & ND & UG/I & $11 / 22 / 94$ & 1.0 & \\
\hline DICHLORODIFLUOROMETHANE & ND & UG/L & $11 / 22 / 94$ & 1.0 & \\
\hline \multicolumn{6}{|l|}{ DILUTION FACTOR: 5 TIMES } \\
\hline \multicolumn{6}{|l|}{ PERCENT SURROGATE RECOVERY: } \\
\hline 1,4-Dichlorobutane & 1208 & & & & \\
\hline
\end{tabular}

- ANALYTICAL RESULTS - 


\begin{tabular}{|llll|}
\hline TO: & KAI Technologies, InC. & DATE RECEIVED & $: 11 / 21 / 94$ \\
$175 \mathrm{~N}$. New Boston St. & DATE COLLECTED & $11 / 15 / 94$ \\
WOburn, MA 01801 & COLLECTED BY & $:$ SAME \\
ATTN : Steven Price & MATRIX & $:$ Water \\
PO/ID NUMBER : $94-75$ & AA52758 & & \\
SAMPLE DESCRIPTION: Test 3.3-Sample 3 & & \\
\hline
\end{tabular}

- ANALYTICAL RESULTS -

\section{PARAMETER}

CHLOROMETHANE VINYL CHLORIDE BROMOMETHANE CHLORETHANE TRICHLOROFLUOROMETHANE 1,1-DICHLOROETHENE METHYLENE CHLORIDE TRANS-1,2-DICHLOROETHENE 1, 1-DICHLOROETHANE CHLOROFORM (THM) $1,1,1-T R I C H L O R O E T H A N E$ CARBON TETRACHLORIDE 1,2-DICHLOROETHANE TRICHLOROETHENE 1,2-DICHLOROPROPANE BROMODICHLOROMETHANE (THM) CIS-1, 3-DICHLOROPROPENE 2-CHLOROETHYLVINYL ETHER TRANS-1, 3-DICHLOROPROPENE $1,1,2-T R I C H L O R O E T H A N E$ TETRACHLOROETHENE DIBROMOCHLOROMETHANE (THM) CHLOROBENZENE BROMOFORM (THM) $1,1,2,2$-TETRACHLOROETHANE 1,3-DICHLOROBENZENE 1,4-DICHLOROBENZENE 1,2-DICHLOROBENZENE DICHLORODIFLUOROMETHANE DILUTION FACTOR: 5 TIMES PERCENT SURROGATE RECOVERY: 1,4-Dichlorobutane

\begin{tabular}{ll}
\hline \multicolumn{1}{c|}{ RESULT } & UOM \\
\cline { 2 - 2 } ND & UG/L \\
ND & UG/L \\
ND & UG/L \\
ND & UG/L \\
ND & UG/L \\
ND & UG/L \\
ND & UG/L \\
ND & UG/L \\
ND & UG/L \\
ND & UG/L \\
ND & UG/L \\
ND & UG/L \\
ND & UG/L \\
ND & UG/L \\
ND & UG/L \\
ND & UG/L \\
ND & UG/L \\
ND & UG/L \\
ND & UG/L \\
ND & UG/L \\
5, 705 & UG/L \\
ND & UG/L \\
ND & UG/L \\
ND & UG/L \\
ND & UG/L \\
ND & UG/L \\
ND & UG/L \\
ND & UG/L \\
ND & UG/L \\
&
\end{tabular}

1158

\section{TEST DATE}

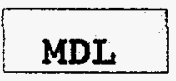

METHOD

\section{$11 / 22 / 94$}

1.0

$11 / 22 / 94 \quad 1.0$

$11 / 22 / 94 \quad 1.0$

$11 / 22 / 94 \quad 1.0$

$11 / 22 / 94 \quad 1.0$

$11 / 22 / 94 \quad 1.0$

$11 / 22 / 94$

$11 / 22 / 94$

$11 / 22 / 94$

$11 / 22 / 94$

$11 / 22 / 94$

$11 / 22 / 94$

$11 / 22 / 94$

$11 / 22 / 94$

$11 / 22 / 94$

$11 / 22 / 94$

$11 / 22 / 94$

$11 / 22 / 94$

$11 / 22 / 94$

$11 / 22 / 94$

$11 / 22 / 94$

$11 / 22 / 94$

$11 / 22 / 94$

$11 / 22 / 94$

$11 / 22 / 94$

$11 / 22 / 94$

$11 / 22 / 94$

$11 / 22 / 94$

$11 / 22 / 94$
1.0

1.0

1.0

1.0

1.0

1.0

1.0

1.0

1.0

1.0

1.0

1.0

1.0

1.0

1.0

1.0

1.0

1.0

1.0

1.0

1.0

1.0

1.0
EPA 601

EPA 601

EPA 601

EPA 601

EPA 601

EPA 601

EPA 601

EPA 601

EPA 601

EPA 601

EPA 601

EPA 601

EPA 601

EPA 601

EPA 601

EPA 601

EPA 601

EPA 601

EPA 601

EPA 601

EPA 601

EPA 601

EPA 601

EPA 601

EPA 601

EPA 601

EPA 601

EPA 601

EPA 601

These results apply only to the actual sample as tested. The integrity of resuits is dependent upon the quality of the sampling technique and subsequent handling. Actual detection limits are the above reported MDL's multiplied by dilution factors, if any. American Environmental Laboratories, Inc. shall not be held liable for any interpretation of analytical results. 


\begin{tabular}{|lll||}
\hline TO: KAI Technologies, InC. & DATE RECEIVED $: 11 / 21 / 94$ \\
175 N. New Boston St. & DATE COLLECTED & $11 / 15 / 94$ \\
Woburn, MA 01801 & COLLECTED BY $:$ SAME \\
ATTN: Steven Price & MATRIX & Water \\
PO/ID NUMBER : $94-75$ & AA52758 & \\
SAMPLE DESCRIPTION: Test 3.3-Sample 4 & & \\
\hline
\end{tabular}

- ANALYTICAL RESULTS -

\section{PARAMETER}

CHLOROMETHANE

VINYI CHLORIDE

BROMOMETHANE

CHLORETHANE

TRICHLOROF LUOROMETHANE

1,1-DICHLOROETHENE

METHYLENE CHLORIDE

TRANS-1,2-DICHLOROETHENE

1,1-DICHLOROETHANE

CHLOROFORM (THM)

$1,1,1-T R I C H L O R O E T H A N E$

CARBON TETRACHLORIDE

1,2-DICHLOROETHANE

TRICHLOROETHENE

1,2-DICHLOROPROPANE

BROMODICHLOROMETHANE (THM)

CIS-1, 3-DICHLOROPROPENE

2-CHLOROETHYIVINYI ETHER

TRANS-1, 3-DICHLOROPROPENE

1, 1,2-TRICHLOROETHANE

TETRACHLOROETHENE

DIBROMOCHLOROMETHANE (THM)

CHLOROBENZENE

BROMOFORM (THM)

$1,1,2,2$-TETRACHLOROETHANE

1,3-DICHLOROBENZENE

1,4-DICHLOROBENZENE

1,2-DICHLOROBENZENE

DICHLORODIFLUOROMETHANE

DILUTION FACTOR: 5 TIMES

PERCENT SURROGATE RECOVERY:

1,4-Dichlorobutane

\begin{tabular}{|c|c|}
\hline RESULT & UON \\
\hline ND & $\mathrm{UG} / \mathrm{L}$ \\
\hline ND & UG/L \\
\hline ND & $\mathrm{UG} / \mathrm{L}$ \\
\hline ND & $\mathrm{UG} / \mathrm{L}$ \\
\hline ND & UG/L \\
\hline ND & UG/L \\
\hline ND & UG/L \\
\hline ND & $\mathrm{UG} / \mathrm{L}$ \\
\hline ND & UG/L \\
\hline ND & UG/L \\
\hline ND & UG/L \\
\hline ND & $\mathrm{UG} / \mathrm{L}$ \\
\hline ND & $\mathrm{UG} / \mathrm{L}$ \\
\hline ND & UG/I \\
\hline ND & UG/L \\
\hline ND & $\mathrm{UG} / \mathrm{I}$ \\
\hline ND & UG/L \\
\hline ND & UG/L \\
\hline ND & $\mathrm{UG} / \mathrm{L}$ \\
\hline ND & UG / L \\
\hline 17,390 & UG/L \\
\hline ND & UG / I \\
\hline ND & UG $/ \mathrm{L}$ \\
\hline ND & UG/L \\
\hline ND & UG/L \\
\hline ND & UG/I \\
\hline ND & UG/I \\
\hline ND & UG/I \\
\hline ND & UG/ \\
\hline
\end{tabular}

958

\section{TEST DATE}

$11 / 22 / 94$

$11 / 22 / 94$

$11 / 22 / 94$

$11 / 22 / 94$

$11 / 22 / 94$

$11 / 22 / 94$

$11 / 22 / 94$

$11 / 22 / 94$

$11 / 22 / 94$

$11 / 22 / 94$

$11 / 22 / 94$

$11 / 22 / 94$

$11 / 22 / 94$

$11 / 22 / 94$

$11 / 22 / 94$

$11 / 22 / 94$.

$11 / 22 / 94$

$11 / 22 / 94$

$11 / 22 / 94$

$11 / 22 / 94$

$11 / 22 / 94$

$11 / 22 / 94$

$11 / 22 / 94$

$11 / 22 / 94$

$11 / 22 / 94$

$11 / 22 / 94$

$11 / 22 / 94$

$11 / 22 / 94$

$11 / 22 / 94$

\section{MDL}

1.0

1.0

1.0

1.0

1.0

1.0

1.0

1.0

1.0

1.0

1.0

1.0

1.0

1.0

1.0

1.0

1.0

1.0

1.0

1.0

1.0

1.0

1.0

1.0

1.0

1.0

1.0

1.0

1.0

\section{METHOD}

EPA 601

EPA 601

EPA 601

EPA 601

EPA 601

EPA 601

EPA 601

EPA 601

EPA 601

EPA 601

EPA 601

EPA 601

EPA 601

EPA 601

EPA 601

EPA 601

EPA 601

EPA 601

EPA 601

EPA 601

EPA 601

EPA 601

EPA 601

EPA 601

EPA 601

EPA 601

EPA 601

EPA 601

EPA 601

These results apply only to the actual sample as tested. The integrity of results is dependent upon the quality of the sampling technique and subsequent handling. Actual detection limits are the above reported MDL's multiplied by dilution factors, if any. American Environmental Laboratories, Inc. shall not be held liable for any interpretation of analytical results. 


\begin{tabular}{|lll|}
\hline TO: KAI Technologies, InC. & DATE RECEIVED $: 11 / 21 / 94$ \\
$175 \mathrm{~N}$. New BOston St. & DATE COLLECTED $11 / 15 / 94$ \\
WOburn, MA 01801 & COLLECTED BY $:$ SAME \\
ATTN: Steven Price & MATRIX & Water \\
PO/ID NUMBER : $94-75$ & AA52758 & \\
SAMPLE DESCRIPTION: Test $3.3-$ Sample 5
\end{tabular}

- ANALYTICAL RESULTS -

PARAMETER

CHLOROMETHANE

VINYI CHLORIDE BROMOMETHANE CHLORETHANE TRICHLOROFLUOROMETHANE 1,1-DICHLOROETHENE METHYLENE CHLORIDE TRANS-1, 2-DICHLOROETHENE 1,1-DICHLOROETHANE CHLOROFORM (THM) 1, 1, 1-TRICHLOROETHANE CARBON TETRACHLORIDE 1,2-DICHLOROETHANE TRICHLOROETHENE 1,2-DICHLOROPROPANE BROMODICHLOROMETHANE (THM) CIS-1, 3-DICHLOROPROPENE 2-CHLOROETHYIVINYL ETHER TRANS-1, 3-DICHLOROPROPENE 1, 1,2-TRICHLOROETHANE TETRACHLOROETHENE DIBROMOCHLOROMETHANE (THM) CHLOROBENZENE BROMOFORM (THM)

$1,1,2,2$-TETRACHLOROETHANE

1,3-DICHLOROBENZENE

$1,4-D I C H L O R O B E N Z E N E$

1, 2-DICHLOROBENZENE

DICHLORODIFIUOROMETHANE

DILUTION FACTOR: 5 TIMES PERCENT SURROGATE RECOVERY: 1,4-Dichlorobutane

\begin{tabular}{ll|l}
\cline { 2 - 2 } RESULT & UOM \\
\cline { 2 - 2 } ND & UG/L \\
ND & UG/L \\
ND & UG/L \\
ND & UG/L \\
ND & UG/L \\
ND & UG/L \\
ND & UG/L \\
ND & UG/L \\
ND & UG/L \\
ND & UG/L \\
ND & UG/L \\
ND & UG/L \\
ND & UG/L \\
ND & UG/L \\
ND & UG/L \\
ND & UG/L \\
ND & UG/L \\
ND & UG/L \\
ND & UG/L \\
ND & UG/L \\
5, 765 & UG/L \\
ND & UG/L \\
ND & UG/L \\
ND & UG/L \\
ND & UG/L \\
ND & UG/L \\
ND & UG/L \\
ND & UG/L \\
ND & UG/L \\
& \\
&
\end{tabular}
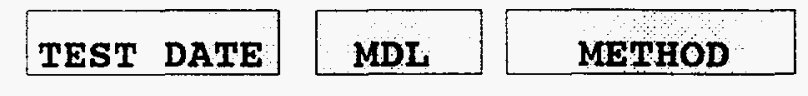

EPA 601

$11 / 22 / 94$
$11 / 22 / 94$

1.0

$11 / 22 / 94$

1.0

$11 / 22 / 94$

1.0

$11 / 22 / 94$

1.0

$11 / 22 / 94$

1. 0

$11 / 22 / 94$

1.0

$11 / 22 / 94$

1.0

$11 / 22 / 94$

1. 0

$11 / 22 / 94$

1. 0

$11 / 22 / 94$

1.0

$11 / 22 / 94$

1.0

1.0

$11 / 22 / 94$

$11 / 22 / 94$

1.0

$11 / 22 / 94$

$11 / 22 / 94$

1.0

1.0

1.0

$11 / 22 / 94$

1.0

$11 / 22 / 94$

1.0

$11 / 22 / 94$

1.0

$11 / 22 / 94$

1.0

$11 / 22 / 94$

1. 0

1. 0

$11 / 22 / 94$

$11 / 22 / 94$

1. 0

1. 0

1. 0

$11 / 22 / 94$

$11 / 22 / 94$

1.0

1.0

$11 / 22 / 94$

1.0

$11 / 22 / 94$

1.0

108 웅
EPA 601

EPA 601

EPA 601

EPA 601

EPA 601

EPA 601

EPA 601

EPA 601

EPA 601

EPA 601

EPA 601

EPA 601

EPA 601

EPA 601

EPA 601

EPA 601

EPA 601

EPA 601

EPA 601

EPA 601

EPA 601

EPA 601

EPA 601

EPA 601

EPA 601

EPA 601

EPA 601

EPA 601

These results apply only to the actual sample as tested. The integrity of results is dependent upon the quality of the sampling technique and subsequent handling. Actual detection limits are the above reported MDL's multiplied by dilution factors, if any. American Environmental Laboratories, Inc. shall not be held liable for any interpretation of analytical results. 
TO: KAI Technologies, Inc. $175 \mathrm{~N}$. New Boston st. Woburn, MA 01801

ATTN: Steven Price

PO/ID NUMBER : $94-75$
DATE RECEIVED : $11 / 21 / 94$

DATE COLLECTED $\quad 11 / 15 / 94$

COLLECTED BY $:$ SAME

MATRIX

- Water

SAMPLE DESCRIPTION: Test 3.3 - Sample 6

\section{PARAMETER}

CHLOROMETHANE

VINYI CHLORIDE

BROMOMETHANE

CHLORETHANE

TRICHLOROFLUOROMETHANE

1,1-DICHLOROETHENE

METHYLENE CHLORIDE

TRANS-1,2-DICHLOROETHENE

1, 1-DICHLOROETHANE

CHLOROFORM (THM)

$1,1,1$-TRICHLOROETHANE

CARBON TETRACHLORIDE

1,2-DICHLOROETHANE

TRICHLOROETHENE

1,2-DICHLOROPROPANE

BROMODICHLOROMETHANE (THM)

CIS-1, 3-DICHLOROPROPENE

2-CHLOROETHYLVINYL ETHER

TRANS-1,3-DICHLOROPROPENE

$1,1,2-T R I C H L O R O E T H A N E$

TETRACHLOROETHENE

DIBROMOCHLOROMETHANE (THM)

CHLOROBENZENE

BROMOFORM (THM)

$1,1,2,2$-TETRACHLOROETHANE

1,3-DICHLOROBENZENE

1,4-DICHLOROBENZENE

1,2-DICHLOROBENZENE

DICHLORODIFLUOROMETHANE

DILUTION FACTOR: 5 TIMES

PERCENT SURROGATE RECOVERY:

1,4-Dichlorobutane

\section{- ANALYTICAL RESULTS -}

\begin{tabular}{|c|c|c|c|c|}
\hline RESULT & UOM & TEST DATE & MDL & METHOD \\
\hline ND & UG/L & $11 / 22 / 94$ & 1.0 & EPA 601 \\
\hline ND & $\mathrm{UG} / \mathrm{L}$ & $11 / 22 / 94$ & 1.0 & EPA 601 \\
\hline ND & UG / I & $11 / 22 / 94$ & 1.0 & EPA 601 \\
\hline ND & $\mathrm{UG} / \mathrm{I}$ & $11 / 22 / 94$ & 1.0 & EPA 601 \\
\hline ND & $\mathrm{UG} / \mathrm{L}$ & $11 / 22 / 94$ & 1.0 & EPA 601 \\
\hline ND & UG/L & $11 / 22 / 94$ & 1.0 & EPA 601 \\
\hline ND & UG/L & $11 / 22 / 94$ & 1.0 & EPA 601 \\
\hline ND & UG / L & $11 / 22 / 94$ & 1.0 & EPA 601 \\
\hline ND & UG/L & $11 / 22 / 94$ & 1.0 & EPA 601 \\
\hline ND & UG/L & $11 / 22 / 94$ & 1.0 & EPA 601 \\
\hline ND & UG/L & $11 / 22 / 94$ & 1.0 & EPA 601 \\
\hline ND & UG/L & $11 / 22 / 94$ & 1.0 & EPA 601 \\
\hline ND & UG/L & $11 / 22 / 94$ & 1.0 & EPA 601 \\
\hline ND & UG/L & $11 / 22 / 94$ & 1.0 & EPA 601 \\
\hline ND & UG/L & $11 / 22 / 94$ & 1.0 & EPA 601 \\
\hline ND & $\mathrm{UG} / \mathrm{L}$ & $11 / 22 / 94$ & 1.0 & EPA 601 \\
\hline ND & UG/L & $11 / 22 / 94$ & 1.0 & EPA 601 \\
\hline ND & UG /L & $11 / 22 / 94$ & 1.0 & EPA 601 \\
\hline ND & $\mathrm{UG} / \mathrm{L}$ & $11 / 22 / 94$ & 1.0 & EPA 601 \\
\hline ND & UG/L & $11 / 22 / 94$ & 1.0 & EPA 601 \\
\hline 7,645 & UG/L & $11 / 22 / 94$ & 1.0 & EPA 601 \\
\hline ND & UG / I & $11 / 22 / 94$ & 1.0 & EPA 601 \\
\hline ND & UG/L & $11 / 22 / 94$ & 1.0 & EPA 601 \\
\hline ND & UG/L & $11 / 22 / 94$ & 1.0 & EPA 601 \\
\hline ND & UG/L & $11 / 22 / 94$ & 1.0 & EPA 601 \\
\hline ND & UG/L & $11 / 22 / 94$ & 1.0 & EPA 601 \\
\hline ND & $\mathrm{UG} / \mathrm{L}$ & $11 / 22 / 94$ & 1.0 & EPA 601 \\
\hline ND & UG $/ L$ & $11 / 22 / 94$ & 1.0 & EPA 601 \\
\hline ND & $\mathrm{UG} / \mathrm{L}$ & $11 / 22 / 94$ & 1.0 & EPA 601 \\
\hline 708 & & & & $\begin{array}{l}\text { LYZED BY: } 9 \\
\text { TEWED BY: }\end{array}$ \\
\hline
\end{tabular}

These results apply only to the actual sample as tested. The integrity of results is dependent upon the quality of the sampling technique and subsequent handling. Actual detection limits are the above reported MDL's multiplied by dilution factors, if any. American Environmental Laboratories, Inc. shall not be held liable for any interpretation of analytical results. 


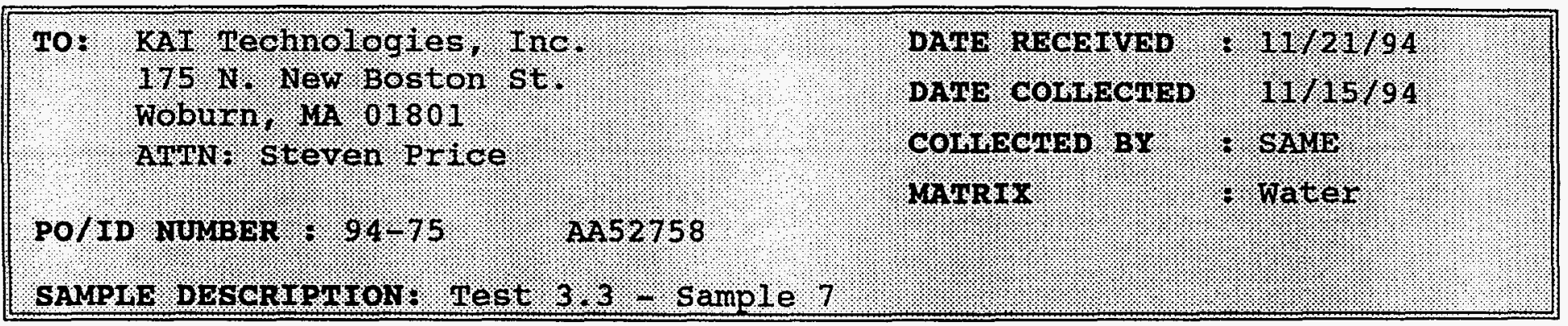

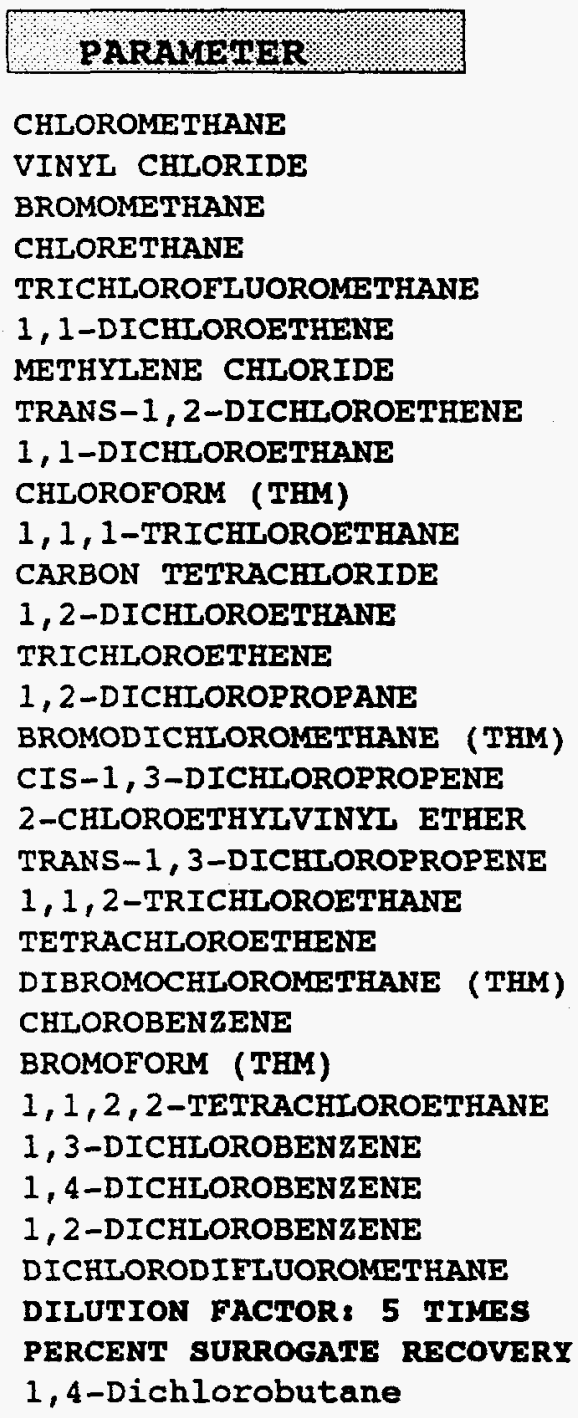

- ANALYTICAL RESULTS -

\begin{tabular}{|c|c|c|c|c|}
\hline RESULT & UOM & MEST DATE & NoI & METHOD \\
\hline ND & UG/L & $11 / 28 / 94$ & 1.0 & EPA 601 \\
\hline ND & UG/I & $11 / 28 / 94$ & 1.0 & EPA 601 \\
\hline ND & UG/I & $11 / 28 / 94$ & 1.0 & EPA 601 \\
\hline ND & UG/L & $11 / 28 / 94$ & 1.0 & EPA 601 \\
\hline ND & UG/L & $11 / 28 / 94$ & 1.0 & EPA 601 \\
\hline ND & UG/I & $11 / 28 / 94$ & 1.0 & EPA 601 \\
\hline ND & UG/L & $11 / 28 / 94$ & 1.0 & EPA 601 \\
\hline ND & UG/L & $11 / 28 / 94$ & 1.0 & EPA 601 \\
\hline ND & UG/I & $11 / 28 / 94$ & 1.0 & EPA 601 \\
\hline ND & UG/L & $11 / 28 / 94$ & 1.0 & EPA 601 \\
\hline ND & UG/L & $11 / 28 / 94$ & 1.0 & EPA 601 \\
\hline ND & $U G / I$ & $11 / 28 / 94$ & 1.0 & EPA 601 \\
\hline ND & $U G / L$ & $11 / 28 / 94$ & 1.0 & EPA 601 \\
\hline ND & UG/L & $11 / 28 / 94$ & 1.0 & EPA 601 \\
\hline ND & UG/L & $11 / 28 / 94$ & 1.0 & EPA 601 \\
\hline ND & UG/L & $11 / 28 / 94$ & 1.0 & EPA 601 \\
\hline ND & UG/L & $11 / 28 / 94$ & 1.0 & EPA 601 \\
\hline ND & UG/L & $11 / 28 / 94$ & 1.0 & EPA 601 \\
\hline ND & UG/L & $11 / 28 / 94$ & 1.0 & EPA 601 \\
\hline 15.0 & UG/L & $11 / 28 / 94$ & 1.0 & EPA 601 \\
\hline 167,775 & UG/L & $11 / 28 / 94$ & 1.0 & EPA 601 \\
\hline ND & UG/L & $11 / 28 / 94$ & 1.0 & EPA 601 \\
\hline ND & UG/L & $11 / 28 / 94$ & 1.0 & EPA 601 \\
\hline ND & $U G / L$ & $11 / 28 / 94$ & 1.0 & EPA 601 \\
\hline ND & $\mathrm{UG} / \mathrm{L}$ & $11 / 28 / 94$ & 1.0 & EPA 601 \\
\hline ND & $\mathrm{UG} / \mathrm{L}$ & $11 / 28 / 94$ & 1.0 & EPA 601 \\
\hline ND & UG/L & $11 / 28 / 94$ & 1.0 & EPA 601 \\
\hline ND & UG/L & $11 / 28 / 94$ & 1.0 & EPA 601 \\
\hline ND & UG/L & $11 / 28 / 94$ & 1.0 & EPA 601 \\
\hline 1138 & & & & $\begin{array}{l}\text { LYZED BY: }(2) \\
\text { IEWED BY: }(f)\end{array}$ \\
\hline
\end{tabular}

These results apply only to the actual sample as tested. The integrity of results is dependent upon the quality of the sampling technique and subsequent handling. Actual detection limits are the above reported MDL's multiplied by dilution factors, if any. American Environmental Laboratories, Inc. shall not be held liable for any interpretation of analytical results. 


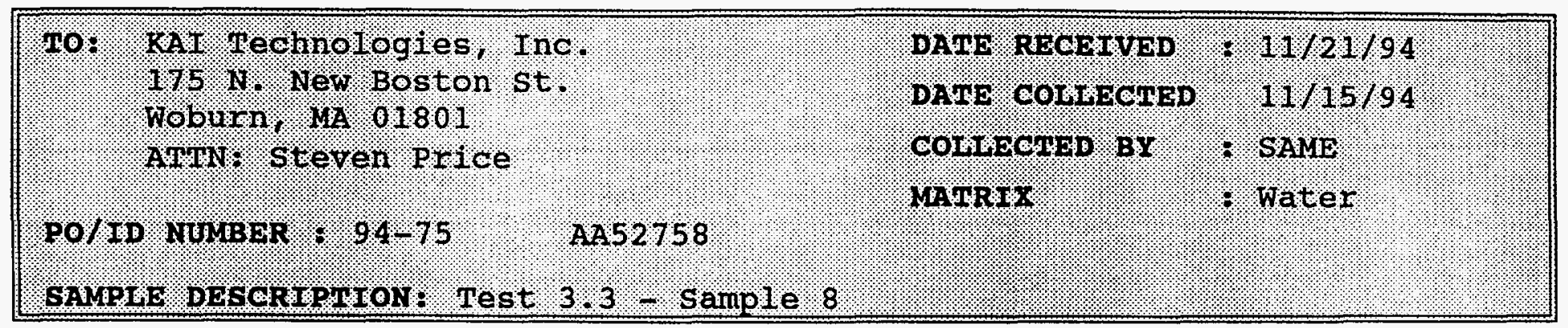

\section{PARAMANER}

CHLOROMETHANE

VINYL CHLORIDE

BROMOMETHANE

CHLORETHANE

TRICHLOROFLUOROMETHANE

1, 1-DICHLOROETHENE

METHYLENE CHLORIDE

TRANS-1, 2-DICHLOROETHENE

1,1-DICHLOROETHANE

CHLOROFORM (THM)

1,1,1-TRICHLOROETHANE

CARBON TETRACHLORIDE

1,2-DICHLOROETHANE

TRICHLOROETHENE

1,2-DICHLOROPROPANE

BROMODICHLOROMETHANE (THM)

CIS-1, 3-DICHLOROPROPENE

2-CHLOROETHYLVINYL ETHER

TRANS-1, 3-DICHLOROPROPENE

1, 1,2-TRICHLOROETHANE

TETRACHLOROETHENE

DIBROMOCHLOROMETHANE (THM)

CHLOROBENZENE

BROMOFORM (THM)

$1,1,2,2$-TETRACHLOROETHANE

1,3-DICHLOROBENZENE

1,4-DICHLOROBENZENE

1,2-DICHLOROBENZENE

DICHLORODIFLUOROMETHANE

DILUTION FACTOR: 5 TIMES

PERCENT SURROGATE RECOVERY:

1,4-Dichlorobutane

- ANALYTICAL RESULTS -

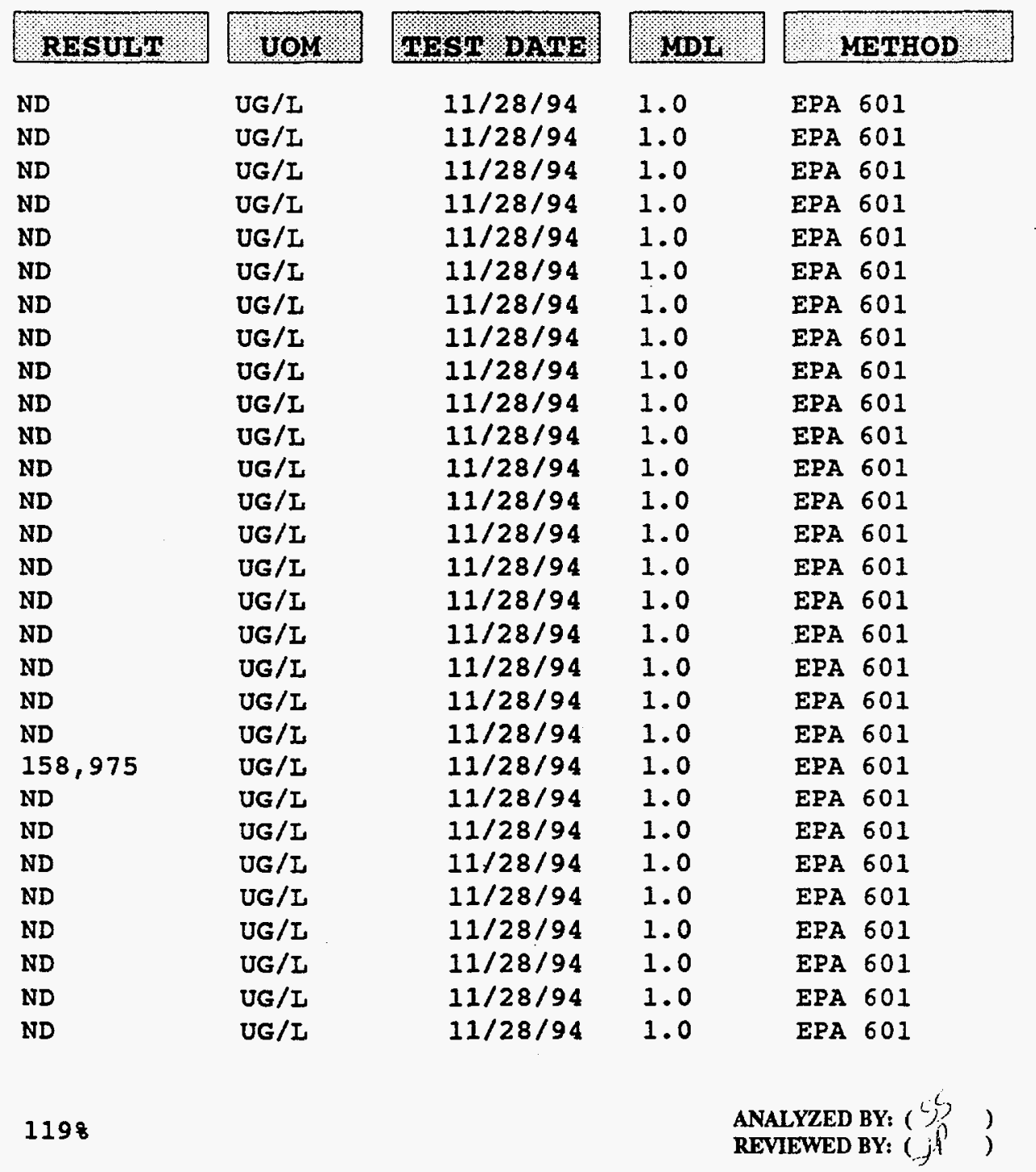

These results apply only to the actual sample as tested. The integrity of results is dependent upon the quality of the sampling technique and subsequent handling. Actual detection limits are the above reported MDL's multiplied by dilution factors, if any. American Environmental Laboratories, Inc. shall not be held liable for any interpretation of analytical results. 


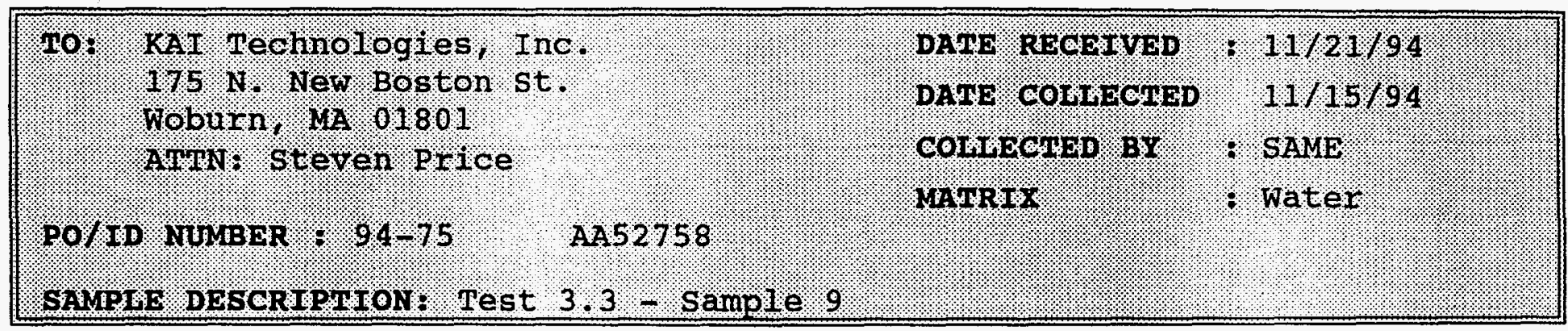

\section{- ANALYTICAL RESULTS -}

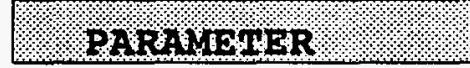

CHLOROMETHANE VINYI CHLORIDE BROMOMETHANE CHLORETHANE TRICHLOROFLUOROMETHANE 1,1-DICHLOROETHENE METHYLENE CHLORIDE TRANS-1,2-DICHLOROETHENE 1, 1-DICHLOROETHANE CHLOROFORM (THM)

1,1,1-TRICHLOROETHANE CARBON TETRACHLORIDE 1,2-DICHLOROETHANE TRICHLOROETHENE 1,2-DICHLOROPROPANE BROMODICHLOROMETHANE (THM) CIS-1, 3-DICHLOROPROPENE 2-CHLOROETHYLVINYL ETHER TRANS-1, 3-DICHLOROPROPENE 1, 1,2-TRICHLOROETHANE TETRACHLOROETHENE DIBROMOCHLOROMETHANE (THM) CHLOROBENZENE BROMOFORM (THM)

$1,1,2,2$-TETRACHLOROETHANE

1,3-DICHLOROBENZENE

1, 4-DICHLOROBENZENE

1,2-DICHLOROBENZENE DICHLORODIFLUOROMETHANE DILUTION FACTOR: 5 TIMES PERCENT SURROGATE RECOVERY: 1,4-Dichlorobutane

\begin{tabular}{|c|c|}
\hline RESULI & UoM \\
\hline ND & $U G / L$ \\
\hline ND & UG/L \\
\hline ND & UG/L \\
\hline ND & UG/L \\
\hline ND & UG/L \\
\hline ND & UG/L \\
\hline ND & UG/L \\
\hline ND & UG/L \\
\hline ND & UG/L \\
\hline ND & UG/L \\
\hline ND & UG/L \\
\hline ND & UG/L \\
\hline ND & UG/L \\
\hline ND & UG/L \\
\hline ND & UG/L \\
\hline ND & $\mathrm{UG} / \mathrm{L}$ \\
\hline ND & UG/I \\
\hline ND & UG/L \\
\hline ND & UG/L \\
\hline 13.0 & UG/L \\
\hline 240,360 & UG/I \\
\hline ND & $\mathrm{UG} / \mathrm{L}$ \\
\hline ND & UG/L \\
\hline ND & UG/L \\
\hline ND & UG/L \\
\hline ND & $\mathrm{UG} / \mathrm{L}$ \\
\hline ND & UG/L \\
\hline ND & UG/L \\
\hline ND & UG/L \\
\hline
\end{tabular}

918

\section{S1 DAME}

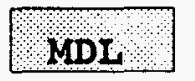

\section{$11 / 28 / 94$ \\ $11 / 28 / 94$}

$11 / 28 / 94$

$11 / 28 / 94$

$11 / 28 / 94$

$11 / 28 / 94$

$11 / 28 / 94$

$11 / 28 / 94$

$11 / 28 / 94$

$11 / 28 / 94$

$11 / 28 / 94$

$11 / 28 / 94$

$11 / 28 / 94$

$11 / 28 / 94$

$11 / 28 / 94$

$11 / 28 / 94$

$11 / 28 / 94$

$11 / 28 / 94$

$11 / 28 / 94$

$11 / 28 / 94$

$11 / 28 / 94$

$11 / 28 / 94$

$11 / 28 / 94$

$11 / 28 / 94$

$11 / 28 / 94$

$11 / 28 / 94$

$11 / 28 / 94$

$11 / 28 / 94$

$11 / 28 / 94$
METHOD

EPA 601

EPA 601

EPA 601

EPA 601

EPA 601

EPA 601

EPA 601

EPA 601

EPA 601

EPA 601

EPA 601

EPA 601

EPA 601

EPA 601

EPA 601

EPA 601

EPA 601

EPA 601

EPA 601

EPA 601

EPA 601

EPA 601

EPA 601

EPA 601

EPA 601

EPA 601

EPA 601

EPA 601

EPA 601

These results apply only to the actual sample as tested. The integrity of results is dependent upon the quality of the sampling technique and subsequent handling. Actual detection limits are the above reported MDL's muitiplied by dilution factors, if any. American Environmental Laboratories, Inc. shall not be held liable for any interpretation of analytical results. 


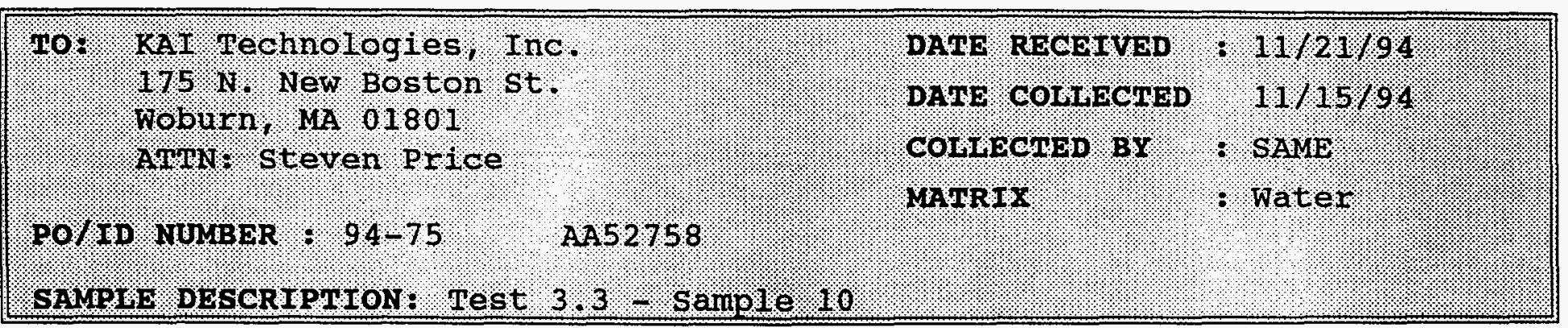

\section{PARAMEIER}

CHLOROMETHANE

VINYL CHLORIDE

BROMOMETHANE

CHLORETHANE

TRICHLOROFLUOROMETHANE

1,1-DICHLOROETHENE

METHYLENE CHLORIDE

TRANS-1, 2-DICHLOROETHENE

1,1-DICHLOROETHANE

CHLOROFORM (THM)

1,1,1-TRICHLOROETHANE

CARBON TETRACHLORIDE

1,2-DICHLOROETHANE

TRICHLOROETHENE

1,2-DICHLOROPROPANE

BROMODICHLOROMETHANE (THM)

CIS-1, 3-DICHLOROPROPENE

2-CHLOROETHYLVINYL ETHER

TRANS-1,3-DICHLOROPROPENE

$1,1,2$-TRICHLOROETHANE

TETRACHLOROETHENE

DIBROMOCHLOROMETHANE (THM)

CHLOROBENZENE

BROMOFORM (THM)

$1,1,2,2$-TETRACHLOROETHANE

1,3-DICHLOROBENZENE

1,4-DICHLOROBENZENE

1,2-DICHLOROBENZENE

DICHLORODIFLUOROMETHANE

DILUTION FACTOR: 5 TIMES

PERCENT SURROGATE RECOVERY:

1,4-Dichlorobutane
- ANALYTICAL RESULTS -

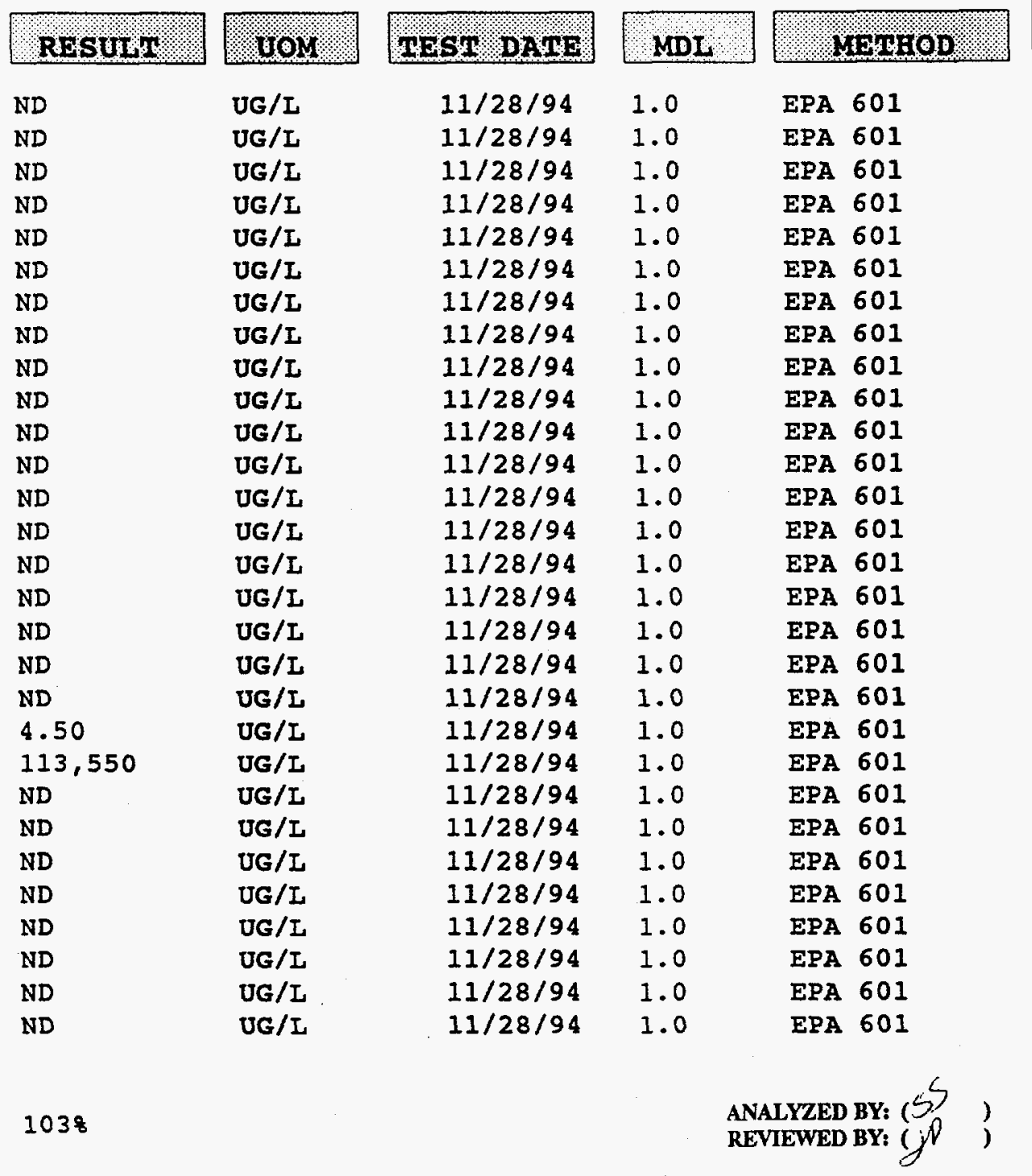

These results apply only to the actual sample as tested. The integrity of results is dependent upon the quality of the sampling technique and subsequent handling. Actual detection limits are the above reported MDL's multiplied by dilution factors, if any. American Environmental Laboratories, Inc. shall not be held liable for any interpretation of analytical results. 


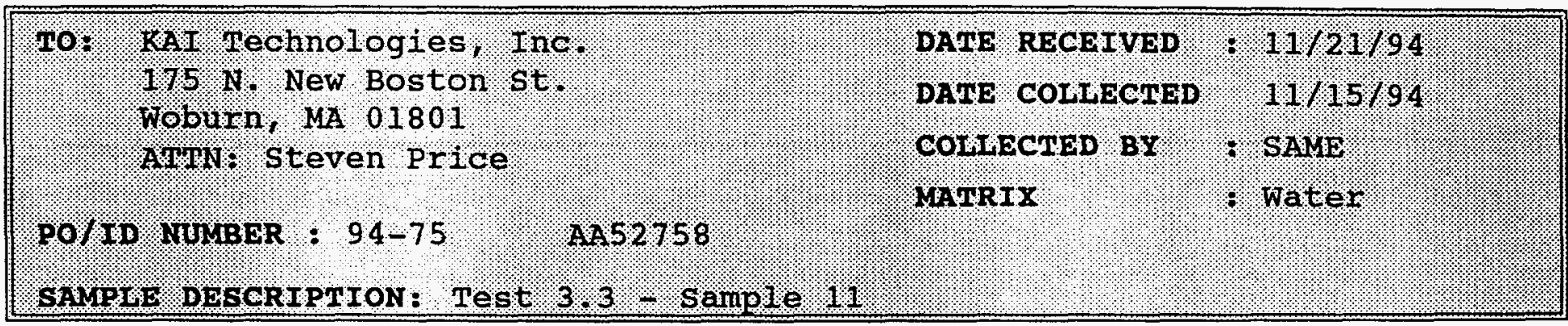

- ANALYTICAL RESULTS -

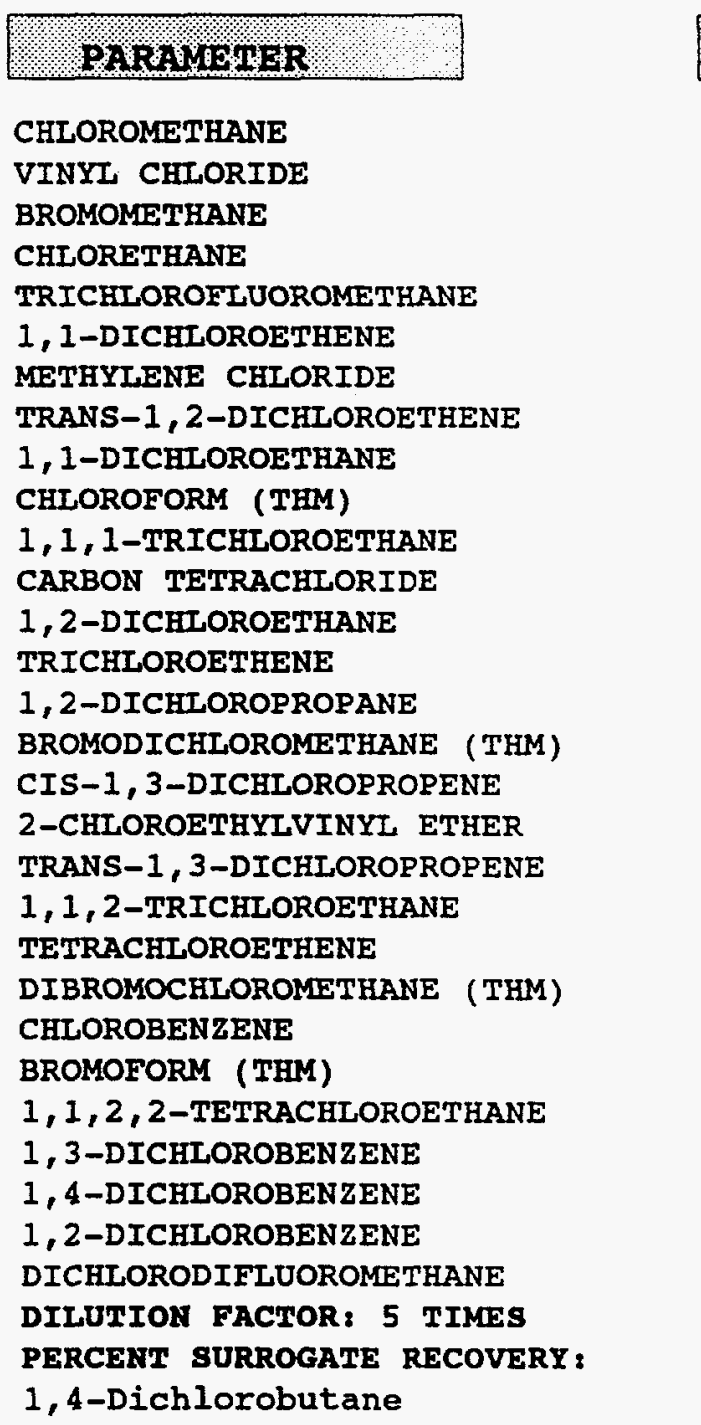

\begin{tabular}{|c|c|}
\hline ResUL1 & vou \\
\hline ND & UG/L \\
\hline ND & UG/L \\
\hline ND & UG/L \\
\hline ND & $U G / I$ \\
\hline ND & $U G / \Sigma$ \\
\hline ND & UG/L \\
\hline ND & UG/L \\
\hline ND & $U G / L$ \\
\hline ND & UG/L \\
\hline ND & UG/I \\
\hline ND & UG/L \\
\hline ND & UG/L \\
\hline ND & UG/I \\
\hline ND & UG/L \\
\hline ND & UG/I \\
\hline ND & UG/L \\
\hline ND & UG/L \\
\hline ND & $U G / L$ \\
\hline ND & UG/L \\
\hline ND & UG/I \\
\hline 169,205 & UG/L \\
\hline ND & $U G / L$ \\
\hline ND & UG/L \\
\hline ND & UG/I \\
\hline ND & UG/I \\
\hline ND & $U G / I$ \\
\hline ND & UG/L \\
\hline ND & UG/I \\
\hline ND & UG/L \\
\hline
\end{tabular}

\section{TEST DATE}

$11 / 28 / 94$

$11 / 28 / 94$

$11 / 28 / 94$

$11 / 28 / 94$

$11 / 28 / 94$

$11 / 28 / 94$

$11 / 28 / 94$

$11 / 28 / 94$

$11 / 28 / 94$

$11 / 28 / 94$

$11 / 28 / 94$

$11 / 28 / 94$

$11 / 28 / 94$

$11 / 28 / 94$

$11 / 28 / 94$

$11 / 28 / 94$

$11 / 28 / 94$

$11 / 28 / 94$

$11 / 28 / 94$

$11 / 28 / 94$

$11 / 28 / 94$

$11 / 28 / 94$

$11 / 28 / 94$

$11 / 28 / 94$

$11 / 28 / 94$

$11 / 28 / 94$

$11 / 28 / 94$

$11 / 28 / 94$

$11 / 28 / 94$

\section{MDI}

1.0

1.0

1.0

1.0

1.0

1.0

1.0

1.0

1.0

1.0

1.0

1.0

1.0

1.0

1.0

1.0

1.0

1.0

1.0

1.0

1.0

1.0

1.0

1.0

1.0

1.0

1.0

1.0

1.0

\section{MEIHOD}

EPA 601

EPA 601

EPA 601

EPA 601

EPA 601

EPA 601

EPA 601

EPA 601

EPA 601

EPA 601

EPA 601

EPA 601

EPA 601

EPA 601

EPA 601

EPA 601

EPA 601

EPA 601

EPA 601

EPA 601

EPA 601

EPA 601

EPA 601

EPA 601

EPA 601

EPA 601

EPA 601

EPA 601

EPA 601

988

These results apply only to the actual sample as tested. The integrity of results is dependent upon the quality of the sampling technique and subsequent handling. Actual detection limits are the above reported MDL's multiplied by dilution factors, if any. American Environmental Laboratories, Inc. shall not be held liable for any interpretation of analytical results. 


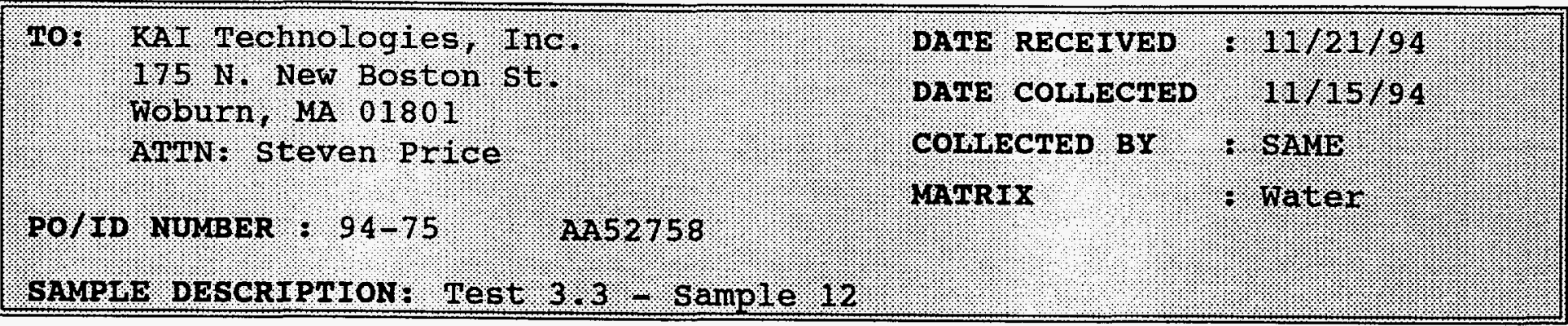

PARAMETER $1 ., \%$

\section{CHLOROMETHANE}

VINYL CHLORIDE BROMOMETHANE CHLORETHANE TRICHLOROFLUOROMETHANE 1, 1-DICHLOROETHENE METHYLENE CHLORIDE TRANS-1, 2-DICHLOROETHENE 1,1-DICHLOROETHANE CHLOROFORM (THM) 1,1,1-TRICHLOROETHANE CARBON TETRACHLORIDE 1,2-DICHLOROETHANE TRICHLOROETHENE 1,2-DICHLOROPROPANE BROMODICHLOROMETHANE (THM) CIS-1, 3-DICHLOROPROPENE 2-CHLOROETHYLVINYL ETHER TRANS-1, 3-DICHLOROPROPENE 1, 1,2-TRICHLOROETHANE TETRACHLOROETHENE DIBROMOCHLOROMETHANE (THM) CHLOROBENZENE BROMOFORM (THM)

$1,1,2,2$-TETRACHLOROETHANE

1, 3-DICHLOROBENZENE

1, 4-DICHLOROBENZENE

1,2-DICHLOROBENZENE DICHLORODIFLUOROMETHANE DILUTION FACTOR: 5 TIMES PERCENT SURROGATE RECOVERY: 1,4-Dichlorobutane

\section{- ANALYTICAL RESULTS -}

\begin{tabular}{|c|c|}
\hline RESUTI & vor \\
\hline ND & UG/I \\
\hline ND & UG/L \\
\hline ND & UG/L \\
\hline ND & UG/I \\
\hline ND & UG/L \\
\hline ND & UG/L \\
\hline ND & UG/I \\
\hline ND & UG/I \\
\hline ND & UG/I \\
\hline ND & UG/I \\
\hline ND & UG/L \\
\hline ND & UG/L \\
\hline ND & UG/I \\
\hline ND & UG/L \\
\hline ND & UG/L \\
\hline ND & UG/I \\
\hline ND & UG/I \\
\hline ND & UG/I \\
\hline ND & UG/L \\
\hline 13.5 & $U G / I$ \\
\hline 38,635 & UG/L \\
\hline ND & UG/L \\
\hline ND & UG/L \\
\hline ND & UG/L \\
\hline ND & UG/L \\
\hline ND & UG/L \\
\hline ND & UG/L \\
\hline ND & $\mathrm{UG} / \mathrm{L}$ \\
\hline ND & UG/L \\
\hline
\end{tabular}

\section{TEST DATE:}

$11 / 28 / 94$

$11 / 28 / 94$

$11 / 28 / 94$

$11 / 28 / 94$

$11 / 28 / 94$

$11 / 28 / 94$

$11 / 28 / 94$

$11 / 28 / 94$

$11 / 28 / 94$

$11 / 28 / 94$

$11 / 28 / 94$

$11 / 28 / 94$

$11 / 28 / 94$

$11 / 28 / 94$

$11 / 28 / 94$

$11 / 28 / 94$

$11 / 28 / 94$

$11 / 28 / 94$

$11 / 28 / 94$

$11 / 28 / 94$

$11 / 28 / 94$

$11 / 28 / 94$

$11 / 28 / 94$

$11 / 28 / 94$

$11 / 28 / 94$

$11 / 28 / 94$

$11 / 28 / 94$

$11 / 28 / 94$

$11 / 28 / 94$

\section{MDI}

1.0

1.0

1.0

1.0

1.0

1.0

1.0

1.0

1.0

1.0

1.0

1.0

1.0

1.0

1.0

1.0

1.0

1.0

1.0

1.0

1.0

1.0

1.0

1.0

1.0

1.0

1.0

1.0

1.0

\section{MDIHOD}

EPA 601

EPA 601

EPA 601

EPA 601

EPA 601

EPA 601

EPA 601

EPA 601

EPA 601

EPA 601

EPA 601

EPA 601

EPA 601

EPA 601

EPA 601

EPA 601

EPA 601

EPA 601

EPA 601

EPA 601

EPA 601

EPA 601

EPA 601

EPA 601

EPA 601

EPA 601

EPA 601

EPA 601

EPA 601

These results apply only to the actual sample as tested. The integrity of results is dependent upon the quality of the sampling technique and subsequent handling. Actual detection limits are the above reported MDL's multiplied by dilution factors, if any. American Environmental Laboratories, Inc. shall not be held liable for any interpretation of analytical results. 


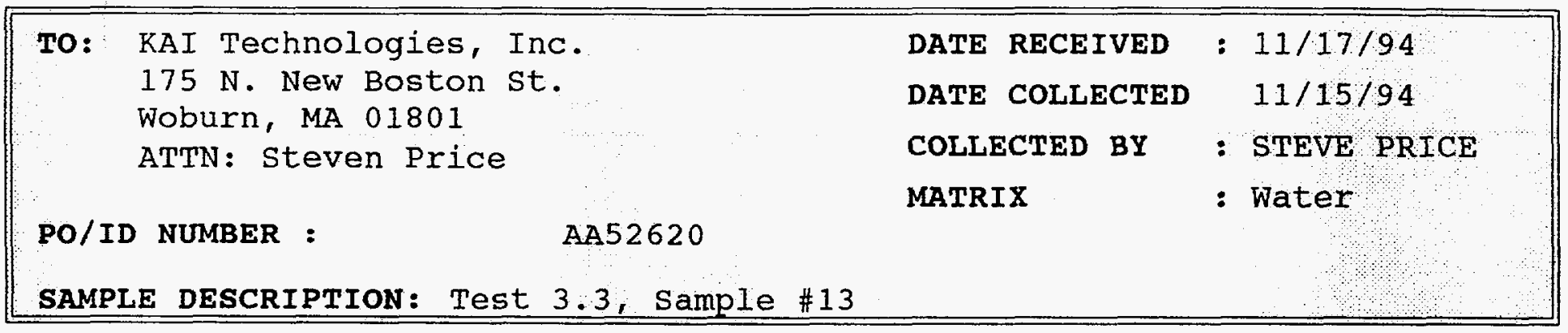

PARAMETER

CHLOROMETHANE VINYL CHLORIDE BROMOMETHANE CHLORETHANE TRICHLOROFLUOROMETHANE 1,1-DICHLOROETHENE METHYLENE CHLORIDE TRANS-1, 2-DICHLOROETHENE 1,1-DICHLOROETHANE CHLOROFORM (THM)

$1,1,1$-TRICHLOROETHANE CARBON TETRACHLORIDE 1,2-DICHLOROETHANE TRICHLOROETHENE 1,2-DICHLOROPROPANE BROMODICHLOROMETHANE (THM) CIS-1, 3-DICHLOROPROPENE 2-CHLOROETHYLVINYL ETHER TRANS-1, 3-DICHLOROPROPENE $1,1,2$-TR ICHLOROETHANE TETRACHLOROETHENE DIBROMOCHLOROMETHANE (THM) CHLOROBENZENE BROMOFORM (THM) $1,1,2,2$-TETRACHLOROETHANE 1,3-DICHLOROBENZENE

1,4-DICHLOROBENZENE

1,2-DICHLOROBENZENE DICHLORODIFLUOROMETHANE DILUTION FACTOR: 5 TIMES PERCENT SURROGATE RECOVERY: 1,4-Dichlorobutane
- ANALYTICAL RESULTS -

\begin{tabular}{|c|c|c|c|c|}
\hline RESULT & UOM & TEST DATE & MDL & METHOD \\
\hline ND & $\mathrm{UG} / \mathrm{L}$ & $11 / 22 / 94$ & 1.0 & EPA 601 \\
\hline ND & UG/I & $11 / 22 / 94$ & 1.0 & EPA 601 \\
\hline ND & UG/I & $11 / 22 / 94$ & 1.0 & EPA 601 \\
\hline ND & UG/L & $11 / 22 / 94$ & 1.0 & EPA 601 \\
\hline ND & UG/L & $11 / 22 / 94$ & 1.0 & EPA 601 \\
\hline ND & UG/L & $11 / 22 / 94$ & 1.0 & EPA 601 \\
\hline ND & UG/I & $11 / 22 / 94$ & 1.0 & EPA 601 \\
\hline ND & UG/L & $11 / 22 / 94$ & 1.0 & EPA 601 \\
\hline ND & UG/L & $11 / 22 / 94$ & 1.0 & EPA 601 \\
\hline ND & UG/L & $11 / 22 / 94$ & 1.0 & EPA 601 \\
\hline ND & UG/L & $11 / 22 / 94$ & 1.0 & EPA 601 \\
\hline ND & $\mathrm{UG} / \mathrm{L}$ & $11 / 22 / 94$ & 1.0 & EPA 601 \\
\hline ND & UG/L & $11 / 22 / 94$ & 1.0 & EPA 601 \\
\hline ND & $\mathrm{UG} / \mathrm{L}$ & $11 / 22 / 94$ & 1.0 & EPA 601 \\
\hline ND & $\mathrm{UG} / \mathrm{L}$ & $11 / 22 / 94$ & 1.0 & EPA 601 \\
\hline ND & UG/I & $11 / 22 / 94$ & 1.0 & EPA 601 \\
\hline ND & UG/L & $11 / 22 / 94$ & 1.0 & EPA 601 \\
\hline ND & UG/L & $11 / 22 / 94$ & 1.0 & EPA 601 \\
\hline ND & $\mathrm{UG} / \mathrm{L}$ & $11 / 22 / 94$ & 1.0 & EPA 601 \\
\hline 27.0 & UG/L & $11 / 22 / 94$ & 1.0 & EPA 601 \\
\hline 3,105 & UG/L & $11 / 22 / 94$ & 1.0 & EPA 601 \\
\hline ND & $\mathrm{UG} / \mathrm{L}$ & $11 / 22 / 94$ & 1.0 & EPA 601 \\
\hline ND & UG/L & $11 / 22 / 94$ & 1.0 & EPA 601 \\
\hline ND & $\mathrm{UG} / \mathrm{L}$ & $11 / 22 / 94$ & 1.0 & EPA 601 \\
\hline ND & $\mathrm{UG} / \mathrm{L}$ & $11 / 22 / 94$ & 1.0 & EPA 601 \\
\hline ND & $\mathrm{UG} / \mathrm{L}$ & $11 / 22 / 94$ & 1.0 & EPA 601 \\
\hline ND & UG/L & $11 / 22 / 94$ & 1.0 & EPA 601 \\
\hline ND & $U G / I$ & $11 / 22 / 94$ & 1.0 & EPA 601 \\
\hline ND & $\mathrm{UG} / \mathrm{L}$ & $11 / 22 / 94$ & 1.0 & EPA 601 \\
\hline
\end{tabular}

ANALYZED BY: $(S S)$ REVIEWED BY: ( g)

These results apply only to the actual sample as tested. The integrity of results is dependent upon the quality of the sampling technique and subsequent handling. Actual detection limits are the above reported MDL's multiplied by dilution factors, if any. American Environmental Laboratories, Inc. shall not be held liable for any interpretation of analytical results. 


\begin{tabular}{|c|c|c|}
\hline $\begin{array}{l}\text { KAI Technologies, Inc. } \\
175 \mathrm{~N} . \text { New Boston st. } \\
\text { Woburn, MA } 01801 \\
\text { ATTN : Steven Price }\end{array}$ & $\begin{array}{l}\text { DATE RECEIVED } \\
\text { DATE COLLECTED } \\
\text { COLLECTED BY } \\
\text { MATRIX }\end{array}$ & $\begin{aligned} &= 11 / 21 / 94 \\
& 11 / 18 / 94 \\
& \text { : } \text { SAME } \\
& \text { : Water }\end{aligned}$ \\
\hline $\begin{array}{l}\text { PO/ID NUMBER }=94-75 \quad \text { AA52757 } \\
\text { SAMPLE DESCRIPTION: Test } 3.3-\text { Sample } 14\end{array}$ & & \\
\hline
\end{tabular}

\section{PARAMETER}

CHLOROMETHANE

VINYL CHLORIDE

BROMOMETHANE

CHLORETHANE

TRICHLOROFLUOROMETHANE

1,1-DICHLOROETHENE

METHYLENE CHLORIDE

TRANS-1, 2-DICHLOROETHENE

1, I-DICHLOROETHANE

CHLOROFORM (THM)

1, 1, 1-TRICHLOROETHANE

CARBON TETRACHLORIDE

1, 2-DICHLOROETHANE

TRICHLOROETHENE

1,2-DICHLOROPROPANE

BROMODICHLOROMETHANE (THM)

CIS-1, 3-DICHLOROPROPENE

2-CHLOROETHYLVINYL ETHER

TRANS-1, 3-DICHLOROPROPENE

$1,1,2$-TRICHLOROETHANE

TETRACHLOROETHENE

DIBROMOCHLOROMETHANE (THM)

CHLOROBENZENE

BROMOFORM (THM)

$1,1,2,2-T E T R A C H I O R O E T H A N E$

1,3-DICHLOROBENZENE

1,4 -DICHLOROBENZENE

1,2-DICHLOROBENZENE

DICHLORODIFLUOROMETHANE

DILUTION FACTOR: 5 TIMES

PERCENT SURROGATE RECOVERY:

1,4-Dichlorobutane
- ANALYTICAL RESULTS -

\begin{tabular}{ll}
\hline RESULT & UOM \\
\cline { 2 - 2 } ND & UG/L \\
ND & UG/L \\
ND & UG/L \\
ND & UG/L \\
ND & UG/L \\
ND & UG/L \\
ND & UG/L \\
ND & UG/L \\
ND & UG/L \\
ND & UG/L \\
ND & UG/L \\
ND & UG/L \\
ND & UG/L \\
ND & UG/L \\
ND & UG/L \\
ND & UG/L \\
ND & UG/L \\
ND & UG/L \\
ND & UG/L \\
24.0 & UG/L \\
8, 465 & UG/L \\
ND & UG/L \\
ND & UG/L \\
ND & UG/L \\
ND & UG/L \\
ND & UG/L \\
ND & UG/L \\
ND & UG/L \\
ND & UG/L \\
&
\end{tabular}

818

\section{TEST DATE}

$11 / 22 / 94$

$11 / 22 / 94$

$11 / 22 / 94$

$11 / 22 / 94$

$11 / 22 / 94$

$11 / 22 / 94$

$11 / 22 / 94$

$11 / 22 / 94$

$11 / 22 / 94$

$11 / 22 / 94$

$11 / 22 / 94$

$11 / 22 / 94$

$11 / 22 / 94$

$11 / 22 / 94$

$11 / 22 / 94$

$11 / 22 / 94$

$11 / 22 / 94$

$11 / 22 / 94$

$11 / 22 / 94$

$11 / 22 / 94$

$11 / 22 / 94$

$11 / 22 / 94$

$11 / 22 / 94$

$11 / 22 / 94$

$11 / 22 / 94$

$11 / 22 / 94$

$11 / 22 / 94$

$11 / 22 / 94$

$11 / 22 / 94$

\section{MDL}

1.0

1.0

1.0

1.0

1.0

1.0

1.0

1.0

1.0

1.0

1.0

1.0

1.0

1.0

1.0

1.0

1.0

1.0

1.0

1.0

1.0

1.0

1.0

1.0

1.0

1.0

1.0

1.0

1.0
METHOD

EPA 601

EPA 601

EPA 601

EPA 601

EPA 601

EPA 601

EPA 601

EPA 601

EPA 601

EPA 601

EPA 601

EPA 601

EPA 601

EPA 601

EPA 601

EPA 601

EPA 601

EPA 601

EPA 601

EPA 601

EPA 601

EPA 601

EPA 601

EPA 601

EPA 601

EPA 601

EPA 601

EPA 601

EPA 601

These results apply only to the actual sample as tested. The integrity of results is dependent upon the quality of the sampling technique and subsequent handling. Actual detection limits are the above reported MDL's multiplied by dilution factors, if any. American Environmental Laboratories, Inc. shall not be held liable for any interpretation of analytical results. 


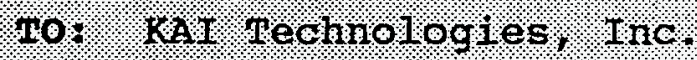
175 . 1\% New Boston st. Hob1110n. $\mathrm{MA}, 01801$.

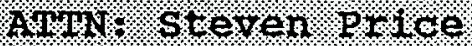

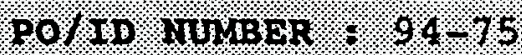
$\mathrm{At.52904}$

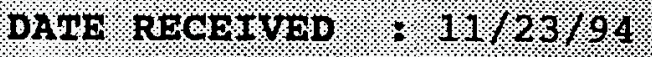

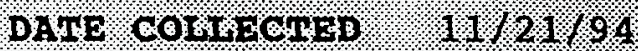

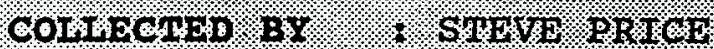

MATR IX

\section{PARAAMTHER}

CHLOROMETHANE

VINYL CHLORIDE

BROMOMETHANE

CELORETHANE

TRICHLOROFLUOROMETHANE

1, 1-DICHLOROETHENE

METHYLENE CHLORIDE

TRANS-1, 2-DICHLOROETHENE

1, 1-DICHLOROETEANE

CHLOROFORM (THM)

1, 1, 1-TRICHLOROETHANE

CARBON TETRACHLORIDE

1, 2-DICHLOROETHANE

TRICHLOROETHENE

1, 2-DICHLOROPROPANE

BROMODICHLOROMETHANE (THM)

CIS-1, 3-DICHLOROPROPENE

2-CHLOROETHYLVINYL ETHER

TRANS-1, 3-DICHLOROPROPENE

$1,1,2-T R I C H L O R O E T H A N E$

TETRACHLOROETHENE

DIBROMOCHLOROMETHANE (THM)

CHLOROBENZENE

BROMOFORM (THM)

$1,1,2,2$-TETRACHLOROETHANE

1, 3-DICHLOROBENZENE

1, 4-DICHLOROBENZENE

1,2-DICHLOROBENZENE

DICHIORODIFLUOROMETHANE

DILUTION FACTOR: NONE

PERCENT SURROGATE RECOVERY :

1,4-Dichlorobutane

- ANALYTICAL RESUETS -

\begin{tabular}{|c|c|}
\hline $\mathrm{RESUTI}$ & UOM \\
\hline ND & UG/L \\
\hline ND & UG/L \\
\hline ND & UG/I \\
\hline ND & UG/L \\
\hline ND & UG/L \\
\hline ND & UG/L \\
\hline ND & UG/I \\
\hline ND & UG/I \\
\hline ND & UG/L \\
\hline ND & UG/I \\
\hline ND & UG/L \\
\hline ND & UG/L \\
\hline ND & UG/I \\
\hline ND & UG/L \\
\hline ND & $\mathrm{UG} / \mathrm{L}$ \\
\hline ND & UG/L \\
\hline ND & UG/L \\
\hline ND & UG/L \\
\hline ND & UG/L \\
\hline 6.00 & UG/L \\
\hline 241,336 & UG /L \\
\hline ND & UG/L \\
\hline ND & UG/L \\
\hline ND & UG/L \\
\hline ND & UG/L \\
\hline ND & UG/L \\
\hline ND & UG/I \\
\hline ND & $\mathrm{UG} / \mathrm{L}$ \\
\hline ND & UG/L \\
\hline
\end{tabular}

\section{TEST DAME}

$11 / 28 / 94$
$11 / 28 / 94$
$11 / 28 / 94$
$11 / 28 / 94$
$11 / 28 / 94$
$11 / 28 / 94$
$11 / 28 / 94$
$11 / 28 / 94$
$11 / 28 / 94$
$11 / 28 / 94$
$11 / 28 / 94$
$11 / 28 / 94$
$11 / 28 / 94$
$11 / 28 / 94$
$11 / 28 / 94$
$11 / 28 / 94$
$11 / 28 / 94$
$11 / 28 / 94$
$11 / 28 / 94$
$11 / 28 / 94$
$11 / 28 / 94$
$11 / 28 / 94$
$11 / 28 / 94$
$11 / 28 / 94$
$11 / 28 / 94$
$11 / 28 / 94$
$11 / 28 / 94$
$11 / 28 / 94$
$11 / 28 / 94$

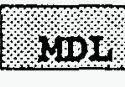

1.0

1.0

1.0

1.0

1.0

1.0

1.0

1.0

1.0

1.0

1.0

1.0

1.0

1.0

1.0

1.0

1.0

1.0

1.0

1.0

1.0

1.0

1.0

1.0

1.0

1.0

1.0

1.0

1.0
21514100

EPA 601

EPA 601

EPA 601

EPA 601

EPA 601

EPA 601

EPA 601

EPA 601

EPA 601

EPA 601

EPA 601

EPA 601

EPA 601

EPA 601

EPA 601

EPA 601

EPA 601

EPA 601

EPA 601

EPA 601

EPA 601

EPA 601

EPA 601

EPA 601

EPA 601

EPA 601

EPA 601

EPA 601

EPA 601 


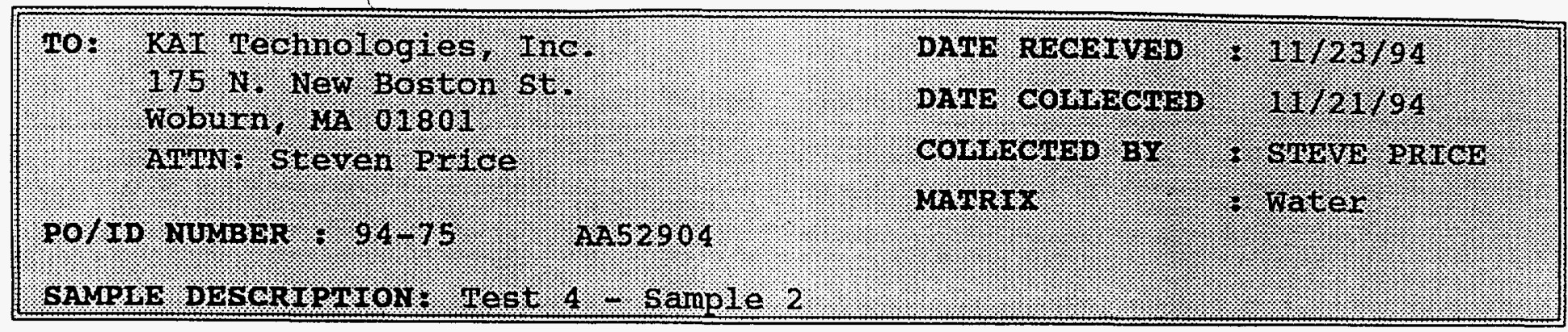

- ANALYTICAL RESULTS -

\section{PARAUNIHR}

CHLOROMETHANE

VINYL CHLORIDE

BROMOMETHANE

CHLORETHANE

TRICHLOROFLUOROMETHANE

1,1-DICHLOROETHENE

METHYLENE CHLORIDE

TRANS-1, 2-DICHLOROETHENE

1,1-DICHLOROETHANE

CHLOROFORM (THM)

$1,1,1$-TRICHLOROETHANE

CARBON TETRACHLORIDE

1,2-DICHLOROETHANE

TRICHLOROETHENE

1,2-DICHLOROPROPANE

BROMODICHLOROMETHANE (THM)

CIS-1, 3-DICHLOROPROPENE

2-CHLOROETHYLVINYL ETHER

TRANS-1, 3-DICHLOROPROPENE

1, 1,2-TRICHLOROETHANE

TETRACHLOROETHENE

DIBROMOCHLOROMETHANE (THM)

CHLOROBENZENE

BROMOFORM (THM)

$1,1,2,2$-TETRACHLOROETHANE

1,3-DICHLOROBENZENE

1,4-DICHLOROBENZENE

1,2-DICHLOROBENZENE

DICHLORODIFLUOROMETHANE

DILUTION FACTOR: WONE

PERCENT SURROGATE RECOVERY \&

1,4-Dichlorobutane

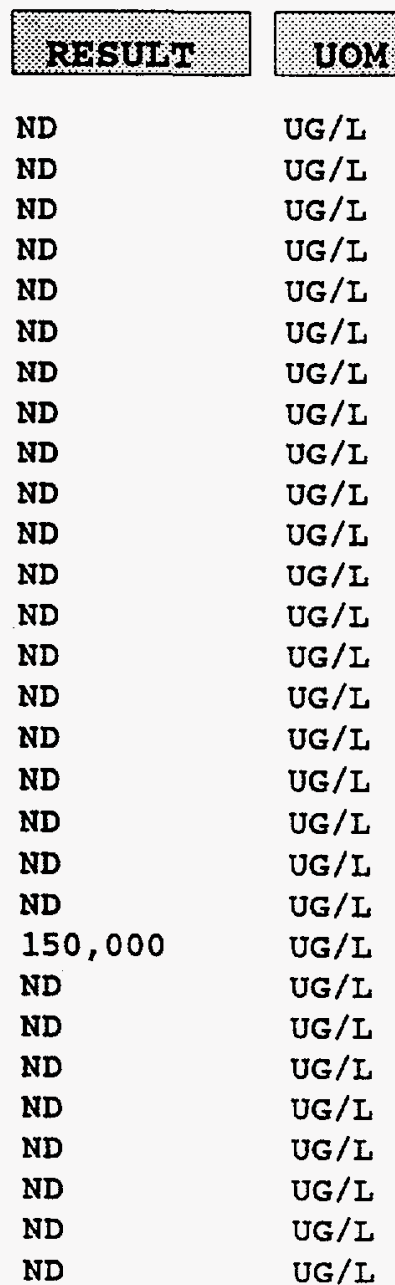

978

\subsection{8}

(101.

$11 / 28 / 94$

1.0

$11 / 28 / 94 \quad 1.0$

$11 / 28 / 94 \quad 1.0$

$11 / 28 / 94 \quad 1.0$

$11 / 28 / 94 \quad 1.0$

$11 / 28 / 94 \quad 1.0$

$11 / 28 / 94 \quad 1.0$

$11 / 28 / 94 \quad 1.0$

$11 / 28 / 94 \quad 1.0$

$11 / 28 / 94 \quad 1.0$

$11 / 28 / 94 \quad 1.0$

$11 / 28 / 94 \quad 1.0$

$11 / 28 / 94 \quad 1.0$

$11 / 28 / 94 \quad 1.0$

$11 / 28 / 94 \quad 1.0$

$11 / 28 / 94 \quad 1.0$

$11 / 28 / 94 \quad 1.0$

$11 / 28 / 94 \quad 1.0$

$11 / 28 / 94 \quad 1.0$

$11 / 28 / 94$

$11 / 28 / 94$

$11 / 28 / 94$

$11 / 28 / 94$

$11 / 28 / 94$

$11 / 28 / 94$

$11 / 28 / 94$

$11 / 28 / 94$

$11 / 28 / 94$

$11 / 28 / 94$

1.0

1.0

1.0

1.0

1.0

1.0

1.0

1.0

1.0

1.0

\section{X12450D}

EPA 601

EPA 601

EPA 601

EPA 601

EPA 601

EPA 601

EPA 601

EPA 601

EPA 601

EPA 601

EPA 601

EPA 601

EPA 601

EPA 601

EPA 601

EPA 601

EPA 601

EPA 601

EPA 601

EPA 601

EPA 601

EPA 601

EPA 601

EPA 601

EPA 601

EPA 601

EPA 601

EPA 601

EPA 601

These results apply only to the actual sample as tested. The integrity of results is dependent upon the quality of the sampling technique and subsequent handling. Actual detection limits are the above reported MDL's multiplied by dilution factors, if any. American Environmental Laboratories, Inc. shall not be heid liable for any interpretation of
analytical results. 


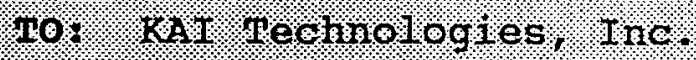

$175,11$. New Boston st.

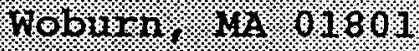

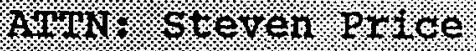

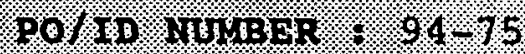

10529014

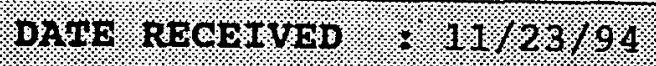

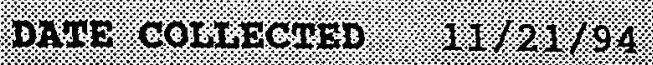

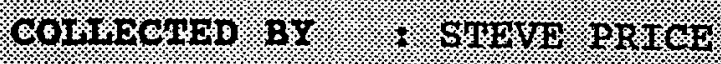

4.141.11\%.

\section{PARAMDTRR}

CHLOROMETHANE

VINYL CHLORIDE

BROMOMETHANE

CHLORETHANE

TRICHLOROFLUOROMETHANE

1, 1-DICHLOROETHENE

METHYLENE CHLORIDE

TRANS-1, 2-DICHLOROETHENE

1, 1-DICHLOROETHANE

CHLOROFORM (THM)

1, 1, 1-TRICHLOROETHANE

CARBON TETRACHLORIDE

1,2-DICHLOROETHANE

TRICHLOROETHENE

1,2-DICHLOROPROPANE

BROMODICHLOROMETHANE (THM)

CIS-1, 3-DICELOROPROPENE

2-CHLOROETHYLVIKYL ETHER

TRANS-1, 3-DICHLOROPROPENE

1,1,2-TRICHLOROETHANE

TETRACHLOROETHENE

DIBROMOCHLOROMETHANE (THM)

CHLOROBENZENE

BROMOFORM (THM)

$1,1,2,2$-TETRACHLOROETHANE

1,3-DICHLOROBENZENE

1,4-DICHLOROBENZENE

1,2-DICHLOROBENZENE

DICHLORODIFLUOROMETHANE

DILUTION FACTOR: 10 TIMES

PERCENT SURROGATE RECOVERY:

1,4-Dichlorobutane
- ANALYTICAL RESULTS -

\begin{tabular}{|c|c|c|c|c|}
\hline RESUIS & UOM & PEST DATE & yot & Yogred \\
\hline ND & UG/L & $12 / 01 / 94$ & 1.0 & EPA 601 \\
\hline ND & UG/L & $12 / 01 / 94$ & 1.0 & EPA 601 \\
\hline ND & UG/L & $12 / 01 / 94$ & 1.0 & EPA 601 \\
\hline ND & $U G / L$ & $12 / 01 / 94$ & 1.0 & EPA 601 \\
\hline ND & UG/L & $12 / 01 / 94$ & 1.0 & EPA 601 \\
\hline ND & UG/I & $12 / 01 / 94$ & 1.0 & EPA 601 \\
\hline ND & UG/L & $12 / 01 / 94$ & 1.0 & EPA 601 \\
\hline ND & $U G / I$ & $12 / 01 / 94$ & 1.0 & EPA 601 \\
\hline ND & UG/I & $12 / 01 / 94$ & 1.0 & EPA 601 \\
\hline ND & UG/L & $12 / 01 / 94$ & 1.0 & EPA 601 \\
\hline ND & $U G / I$ & $12 / 01 / 94$ & 1.0 & EPA 601 \\
\hline ND & UG/L & $12 / 01 / 94$ & 1.0 & EPA 601 \\
\hline ND & UG/L & $12 / 01 / 94$ & 1.0 & EPA 601 \\
\hline ND & UG/L & $12 / 01 / 94$ & 1.0 & EPA 601 \\
\hline ND & UG/L & $12 / 01 / 94$ & 1.0 & EPA 601 \\
\hline ND & UG/L & $12 / 01 / 94$ & 1.0 & EPA 601 \\
\hline ND & UG/L & $12 / 01 / 94$ & 1.0 & EPA 601 \\
\hline ND & UG/L & $12 / 01 / 94$ & 1.0 & EPA 601 \\
\hline ND & UG/L & $12 / 01 / 94$ & 1.0 & EFA 601 \\
\hline ND & UG/L & $12 / 01 / 94$ & 1.0 & EPA 601 \\
\hline 490,000 & $\mathrm{UG} / \mathrm{L}$ & $12 / 01 / 94$ & 1.0 & EPA 601 \\
\hline ND & UG/L & $12 / 01 / 94$ & 1.0 & EPA 601 \\
\hline ND & $\mathrm{UG} / \mathrm{I}$ & $12 / 01 / 94$ & 1.0 & EPA 601 \\
\hline ND & UG/L & $12 / 01 / 94$ & 1.0 & EPA 601 \\
\hline ND & UG/L & $12 / 01 / 94$ & 1.0 & EPA 601 \\
\hline ND & UG/L & $12 / 01 / 94$ & 1.0 & EPA 601 \\
\hline ND & UG/L & $12 / 01 / 94$ & 1.0 & EPA 601 \\
\hline ND & UG/L & $12 / 01 / 94$ & 1.0 & EPA 601 \\
\hline ND & UG/L & $12 / 01 / 94$ & 1.0 & EPA 601 \\
\hline 1058 & & & & $\begin{array}{l}\text { LYZED BY: }(55 \\
\text { IEWED BY: (j) }\end{array}$ \\
\hline
\end{tabular}

These results apply only to the actual sample as tested. The integrity of results is dependent upon the quality of the sampling technique and subsequent handling. Actual detection limits are the above reported MDL's multiplied by dilution factors, if any. American Environmental Laboratories, Inc. shall not be held liable for any interpretation of analytical results. 


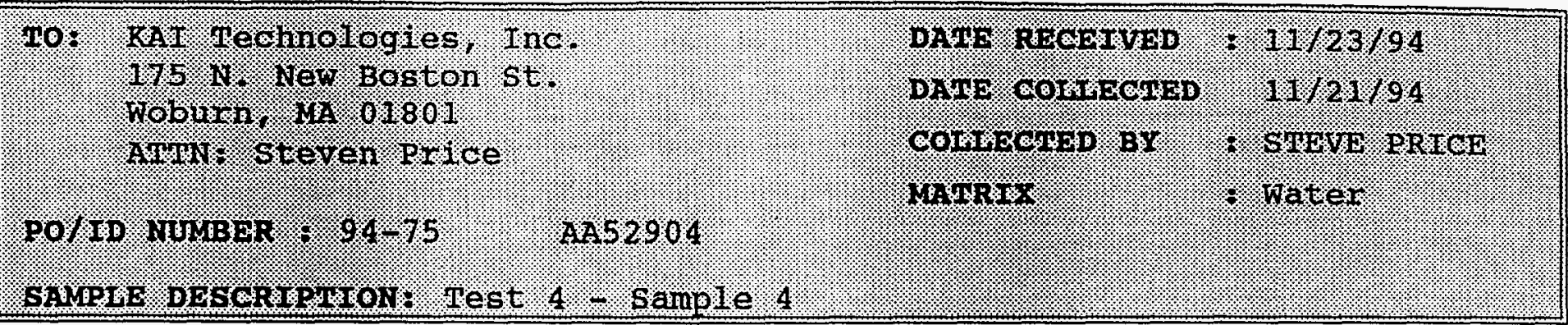

- ANALYTICAL RESULTS -

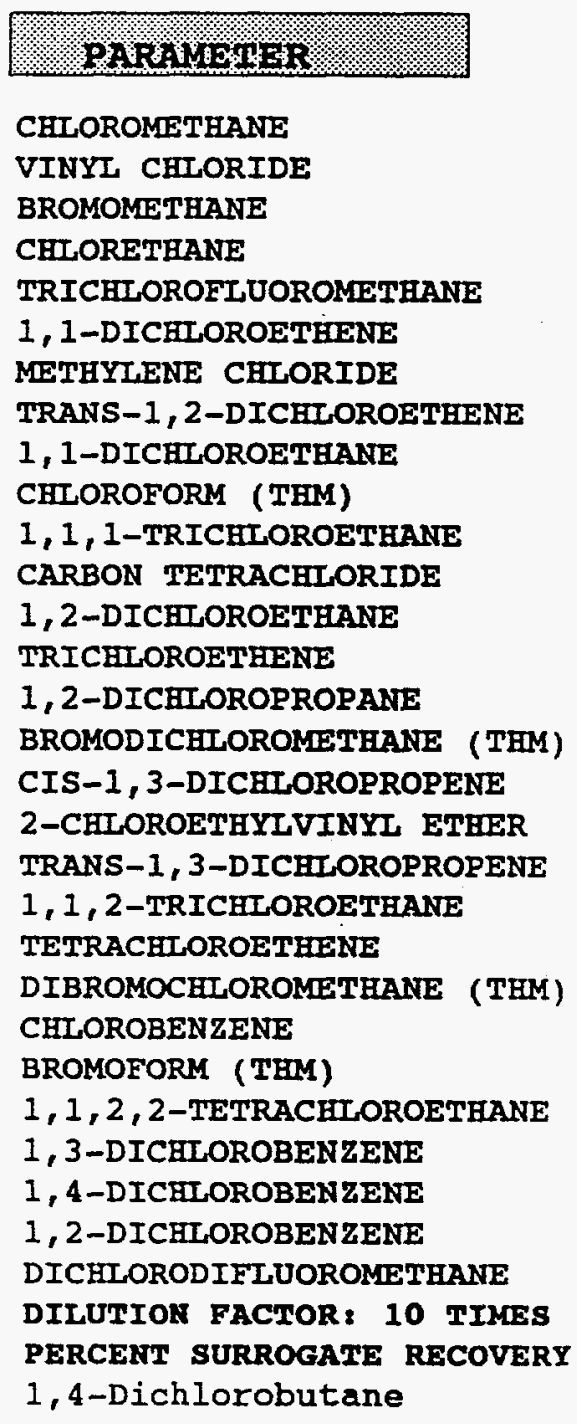

RDSULP:
ND
ND
ND
ND
ND
ND
ND
ND
ND
ND
ND
ND
ND
ND
ND
ND
ND
ND
ND
ND
198, 070
ND
ND
ND
ND
ND
ND
ND
ND
1068
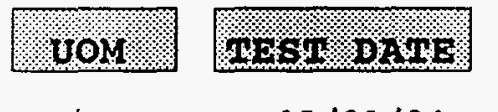

$U G / L$
$U G / I$
$U G / I$

$12 / 01 / 94$

$12 / 01 / 94$

$12 / 01 / 94$

UG/L

UG/L

UG/L

$U G / L$

UG/I

$U G / I$

UG/L

UG/L

UG/L

UG/L

UG/L

$U G / L$

UG/L

UG/L

UG/L

UG/L

UG/L

UG/L

UG/L

$\mathrm{UG} / \mathrm{I}$

UG/L

UG/L

$\mathrm{UG} / \mathrm{I}$

UG/L

UG/L

UG/L

$12 / 01 / 94$

$12 / 01 / 94$

$12 / 01 / 94$

$12 / 01 / 94$

$12 / 01 / 94$

$12 / 01 / 94$

$12 / 01 / 94$

$12 / 01 / 94$

$12 / 01 / 94$

$12 / 01 / 94$

$12 / 01 / 94$

$12 / 01 / 94$

$12 / 01 / 94$

$12 / 01 / 94$

$12 / 01 / 94$

$12 / 01 / 94$

$12 / 01 / 94$

$12 / 01 / 94$

$12 / 01 / 94$

$12 / 01 / 94$

$12 / 01 / 94$

$12 / 01 / 94$

$12 / 01 / 94$

$12 / 01 / 94$

$12 / 01 / 94$

$12 / 01 / 94$

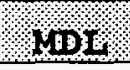

1.0

1.0

1.0

1.0

1.0

1.0

1.0

1.0

1.0

1.0

1.0

1.0

1.0

1.0

1.0

1.0

1.0

1.0

1.0

1.0

1.0

1.0

1.0

1.0

1.0

1.0

1.0

1.0

1.0

\section{METHOD}

EPA 601

EPA 601

EPA 601

EPA 601

EPA 601

EPA 601

EPA 601

EPA 601

EPA 601

EPA 601

EPA 601

EPA 601

EPA 601

EPA 601

EPA 601

EPA 601

EPA 601

EPA 601

EPA 601

EPA 601

EPA 601

EPA 601

EPA 601

EPA 601

EPA 601

EPA 601

EPA 601

EPA 601

EPA 601

These results apply only to the actual sample as tested. The integrity of results is dependent upon the quality of the sampling technique and subsequent handling. Actual detection limits are the above reported MDL's multiplied by dilution factors, if any. American Environmental Laboratories, Inc. shall not be held liable for any interpretation of analytical results. 


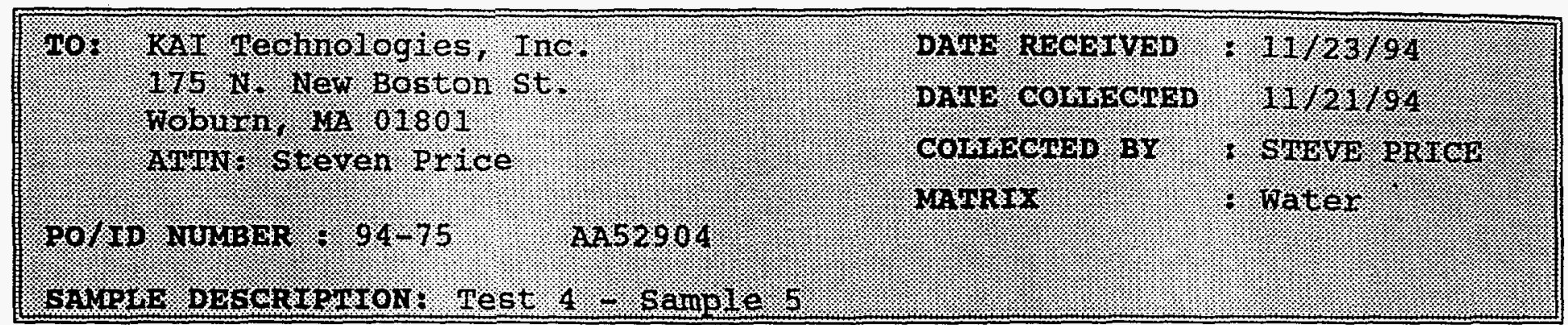

- ANALYTICAL RESUETS -

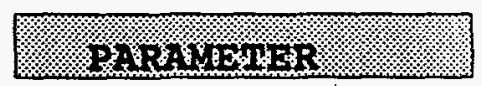

CHLOROMETHANE

VINYL CHLORIDE

BROMOMETHANE

CHLORETHANE

TRICHLOROFLUOROMETHANE

1,1-DICHLOROETHENE

METHYLENE CHLORIDE

TRANS-1, 2-DICHLOROETHENE

1,1-DICHLOROETHANE

CHLOROFORM (THM)

1,1,1-TRICHLOROETHANE

CARBON TETRACHLORIDE

1,2-DICHLOROETHANE

TRICHLOROETHENE

1,2-DICHLOROPROPANE

BROMODICHLOROMETHANE (THM)

CIS-1, 3-DICHLOROPROPENE

2-CHLOROETHYLVINYL ETHER

TRANS-1, 3-DICHLOROPROPENE

1, 1,2-TRICHLOROETHANE

TETRACHLOROETHENE

DIBROMOCHLOROMETHANE (THM)

CHLOROBENZENE

BROMOFORM (THM)

$1,1,2,2$-TETRACHLOROETHANE

1,3-DICHLOROBENZENE

1, 4-DICHLOROBENZENE

1,2-DICHLOROBENZENE

DICHLORODIFLUOROMETHANE

DILUTION FACTOR: 10 TIMES

PERCENT SURROGATE RECOVERY:

1,4-Dichlorobutane

RESUHH:.
ND
ND
ND
ND
ND
ND
ND
ND
ND
ND
ND
ND
ND
ND
ND
ND
ND
ND
ND
ND
I51, 830
ND
ND
ND
ND
ND
ND
ND
ND
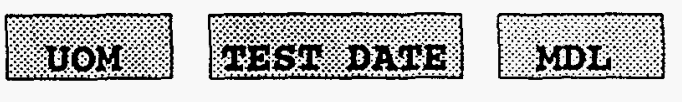

MLAHOD

UG/L

UG/I

UG/L

UG/L

$U G / I$

UG/L

UG/L

UG/I

UG/L

UG/L

UG/L

UG/L

$U G / L$

UG/L

$\mathrm{UG} / \mathrm{L}$

UG/L

UG/L

UG/I

UG/I

UG/L

$U G / L$

UG/L

UG/L

$U G / L$

UG/L

UG/L

UG/L

UG/L

UG/L
1.0

1.0

1.0

1.0

1.0

1.0

1.0

1.0

1.0

1.0

1.0

1.0

1.0

1.0

1.0

1.0

1.0

1.0

1.0

1.0

1.0

1.0

1.0

1.0

1.0

1.0

1.0

1.0

1.0
EPA 601

EPA 601

EPA 601

EPA 601

EPA 601

EPA 601

EPA 601

EPA 601

EPA 601

EPA 601

EPA 601

EPA 601

EPA 601

EPA 601

EPA 601

EPA 601

EPA 601

EPA 601

EPA 601

EPA 601

EPA 601

EPA 601

EPA 601

EPA 601

EPA 601

EPA 601

EPA 601

EPA 601

EPA 601

These results apply only to the actual sample as tested. The integrity of results is dependent upon the quality of the sampling technique and subsequent handling. Actual detection limits are the above reported MDL's multiplied by dilution factors, if any. American Environmental Laboratories, Inc. shall not be held liable for any interpretation of analytical results. 


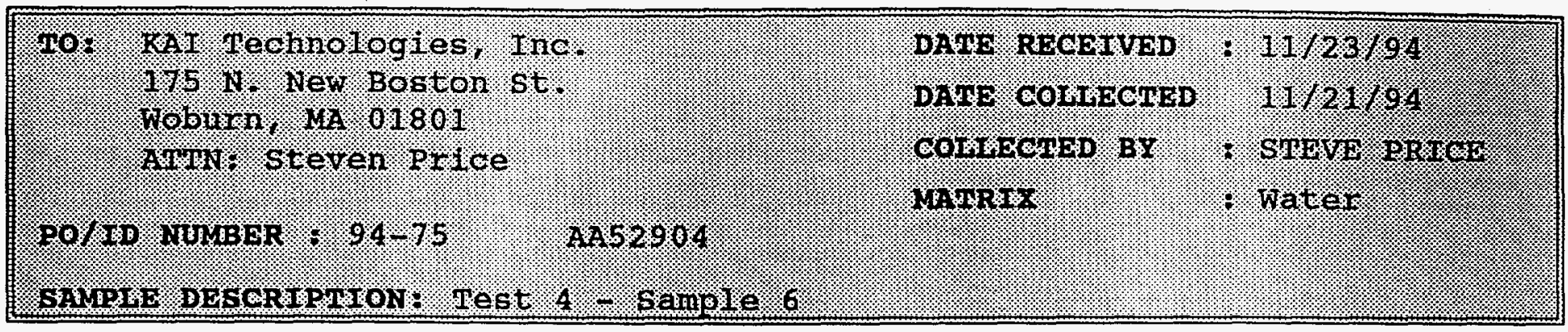

\section{- ANALYTICAL RESULTS -}

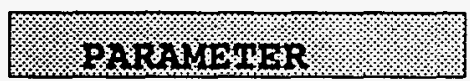

CHLOROMETHANE

VINYL CHLORIDE

BROMOMETHANE

CHIOPETHANE

TRICHIOROFLUOROMETHANE

1,1-DICHLOROETHENE

METHYLENE CHLORIDE

TRANS-1, 2-DICHLOROETHENE

1, 1-DICHLOROETHANE

CHLOROFORM (THM)

1, 1, 1-TRICHLOROETHANE

CARBON TETRACHLORIDE

1,2-DICHLOROETHANE

TRICHLOROETHENE

1,2-DICHLOROPROPANE

BROMODICHLOROMETHANE (THM)

CIS-1, 3-DICHLOROPROPENE

2-CHLOROETHYLVINYL ETHER

TRANS-1, 3-DICHLOROPROPENE

$1,1,2$-TRICHLOROETHANE

TEIRACHLOROETHENE

DIBROMOCHIOROMETHANE (THM)

CHLOROBENZENE

BROMOFORM (THM)

$1,1,2,2$-TETRACELOROETEANE

1, 3-DICHLOROBENZENE

1, 4-DICHLOROBENZENE

1, 2-DICHLOROBENZENE

DICHIORODIFLUOROMETHANE

DILUTIOA FACTOR: 10 TIMES

PERCENT SURROGATE RECOVERY:

1,4-Dichlorobutane

\begin{tabular}{|c|c|}
\hline RESULA & 10N \\
\hline ND & UG/L \\
\hline ND & UG/L \\
\hline ND & UG/L \\
\hline ND & UG/L \\
\hline ND & UG/L \\
\hline ND & $U G / L$ \\
\hline ND & $U G / L$ \\
\hline ND & UG/L \\
\hline ND & UG/L \\
\hline ND & UG/L \\
\hline ND & UG/I \\
\hline ND & UG/L \\
\hline DN & UG/L \\
\hline ND & UG/L \\
\hline ND & UG/L \\
\hline ND & UG/L \\
\hline ND & UG/L \\
\hline ND & UG/L \\
\hline ND & UG/L \\
\hline ND & UG/L \\
\hline 116,000 & UG/L \\
\hline ND & UG/I \\
\hline ND & UG/L \\
\hline ND & UG/L \\
\hline ND & $\mathrm{UG} / \mathrm{L}$ \\
\hline ND & UG/L \\
\hline ND & UG/I \\
\hline ND & UG/L \\
\hline ND & UG/L \\
\hline
\end{tabular}

888

\section{WEST DAME}
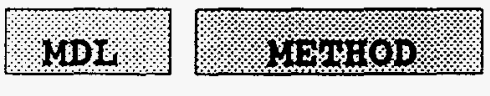

$\begin{array}{ll}12 / 01 / 94 & 1.0 \\ 12 / 01 / 94 & 1.0 \\ 12 / 01 / 94 & 1.0 \\ 12 / 01 / 94 & 1.0 \\ 12 / 01 / 94 & 1.0 \\ 12 / 01 / 94 & 1.0 \\ 12 / 01 / 94 & 1.0 \\ 12 / 01 / 94 & 1.0 \\ 12 / 01 / 94 & 1.0 \\ 12 / 01 / 94 & 1.0 \\ 12 / 01 / 94 & 1.0 \\ 12 / 01 / 94 & 1.0 \\ 12 / 01 / 94 & 1.0 \\ 12 / 01 / 94 & 1.0 \\ 12 / 01 / 94 & 1.0 \\ 12 / 01 / 94 & 1.0 \\ 12 / 01 / 94 & 1.0 \\ 12 / 01 / 94 & 1.0 \\ 12 / 01 / 94 & 1.0 \\ 12 / 01 / 94 & 1.0 \\ 12 / 01 / 94 & 1.0 \\ 12 / 01 / 94 & 1.0 \\ 12 / 01 / 94 & 1.0 \\ 12 / 01 / 94 & 1.0 \\ 12 / 01 / 94 & 1.0 \\ 12 / 01 / 94 & 1.0 \\ 12 / 01 / 94 & 1.0 \\ 12 / 01 / 94 & 1.0 \\ 12 / 01 / 94 & 1.0\end{array}$

EPA 601

EPA 601

EPA 601

EPA 601

EPA 601

EPA 601

EPA 601

EPA 601

EPA 601

EPA 601

EPA 601

EPA 601

EPA 601

EPA 601

EPA 601

EPA 601

EPA 601

EPA 601

EPA 601

EPA 601

EPA 601

EPA 601

EPA 601

EPA 601

EPA 601

EPA 601

EPA 601

EPA 601

EPA 601

These results apply only to the actual sample as tested. The integrity of results is dependent upon the quality of the sampling technique and subsequent handling. Actual detection limits are the above reported MDL's multiplied by dilution factors, if any. American Environmental Laboratories, Inc. shall not be held liable for any interpretation of analytical results. 


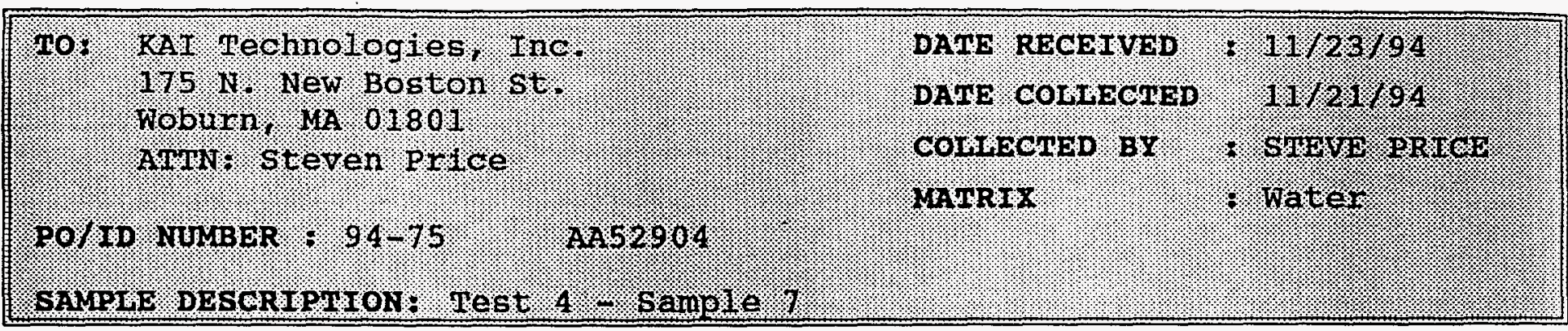

- ANALYTICAL RESULTS -

PARAMETER : 1.10

CHLOROMETHANE

VINYI CHLORIDE

BROMOMETHANE

CHLORETHANE

TRICHLOROFLUOROMETHANE

1,1-DICHLOROETHENE

METHYLENE CHLORIDE

TRANS-1, 2-DICHLOROETHENE

1,1-DICHLOROETHANE

CHLOROFORM (THM)

1, 1, 1-TRICHLOROETHANE

CARBON TETRACHLORIDE

1,2-DICHLOROETHANE

TRICHLOROETHENE

1,2-DICHLOROPROPANE

BROMODICHLOROMETHANE (THM)

CIS-1, 3-DICHLOROPROPENE

2-CHLOROETHYLVINYL ETHER

TRANS-1, 3-DICHLOROPROPENE

1, 1,2-TRICHLOROETHANE

TETRACHLOROETHENE

DIBROMOCHLOROMETHANE (THM)

CHLOROBENZENE

BROMOFORM (THM)

$1,1,2,2$-TETRACHLOROETHANE

1,3-DICHLOROBENZENE

1,4-DICHLOROBENZENE

1, 2-DICELOROBENZENE

DICHLORODIFLUOROMETHANE

DILUTION FACTOR: 10 TIMES

PERCENT SURROGATE RECOVERY:

1,4-Dichlorobutane

\begin{tabular}{|c|c|}
\hline RESU112 & Uou \\
\hline ND & UG/L \\
\hline ND & UG/L \\
\hline ND & UG/L \\
\hline ND & UG/L \\
\hline ND & UG/L \\
\hline ND & $U G / I$ \\
\hline ND & UG/L \\
\hline ND & UG/L \\
\hline ND & $U G / L$ \\
\hline ND & UG/L \\
\hline N & UG/L \\
\hline ND & UG/L \\
\hline ND & UG/L \\
\hline ND & UG/L \\
\hline ND & UG/L \\
\hline ND & UG/I \\
\hline ND & UG/L \\
\hline ND & UG/L \\
\hline ND & UG/L \\
\hline ND & UG/L \\
\hline 96,668 & UG/L \\
\hline ND & $U G / L$ \\
\hline ND & $U G / L$ \\
\hline ND & $\mathrm{UG} / \mathrm{L}$ \\
\hline ND & UG/L \\
\hline ND & UG/L \\
\hline ND & $\mathrm{UG} / \mathrm{L}$ \\
\hline ND & $U G / L$ \\
\hline ND & UG/L \\
\hline
\end{tabular}

1118

\section{TEST DATE}

$12 / 01 / 94$

$12 / 01 / 94$

$12 / 01 / 94$

$12 / 01 / 94$

$12 / 01 / 94$

$12 / 01 / 94$

$12 / 01 / 94$

$12 / 01 / 94$

$12 / 01 / 94$

$12 / 01 / 94$

$12 / 01 / 94$

$12 / 01 / 94$

$12 / 01 / 94$

$12 / 01 / 94$

$12 / 01 / 94$

$12 / 01 / 94$

$12 / 01 / 94$

$12 / 01 / 94$

$12 / 01 / 94$

$12 / 01 / 94$

$12 / 01 / 94$

$12 / 01 / 94$

$12 / 01 / 94$

$12 / 01 / 94$

$12 / 01 / 94$

$12 / 01 / 94$

$12 / 01 / 94$

$12 / 01 / 94$

$12 / 01 / 94$

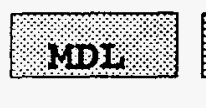

1.0

1.0

1.0

1.0

1.0

1.0

1.0

1.0

1.0

1.0

1.0

1.0

1.0

1.0

1.0

1.0

1.0

1.0

1.0

1.0

1.0

1.0

1.0

1.0

1.0

1.0

1.0

1.0

1.0

XEYHOD

EPA 601

EPA 601

EPA 601

EPA 601

EPA 601

EPA 601

EPA 601

EPA 601

EPA 601

EPA 601

EPA 601

EPA 601

EPA 601

EPA 601

EPA 601

EPA 601

EPA 601

EPA 601

EPA 601

EPA 601

EPA 601

EPA 601

EPA 601

EPA 601

EPA 601

EPA 601

EPA 601

EPA 601

EPA 601

ANALYZED BY: (SS） REVIEWED BY: UP )

These results apply only to the actual sample as tested. The integrity of results is dependent upon the quality of the sampling technique and subsequent handling. Actual detection limits are the above reported MDL's multiplied by dilution factors, if any. American Environmental Laboratories, Inc. shall not be held liable for any interpretation of analytical results. 
- LAB ID \# : MA076 -

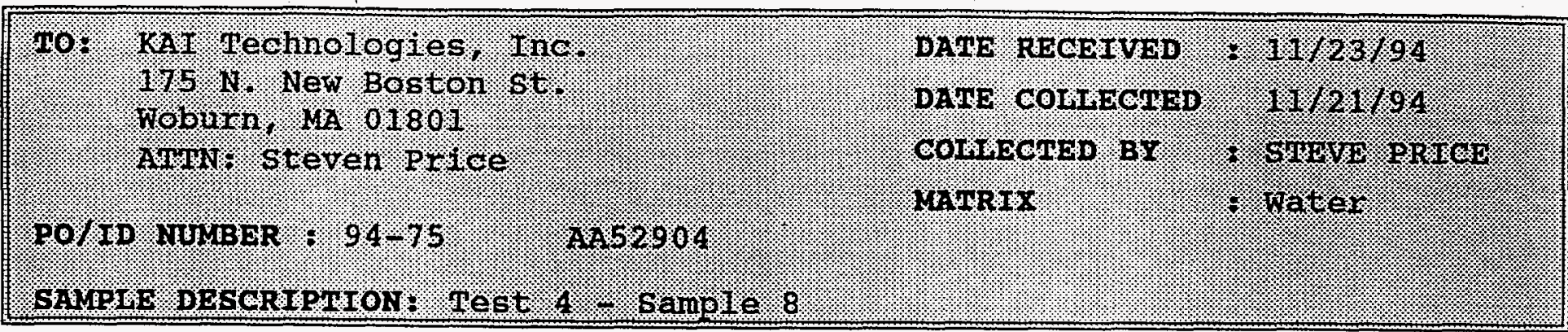

- ANALYTICAL RESULTS -

\section{PARAMRTERR}

CHIOROMETHANE

VINYL CHLORIDE

BROMOMETHANE

CELORETHANE

TRICHLOROFLUOROMETHANE

1,1-DICHLOROETHENE

METHYLENE CHLORIDE

TRANS-1, 2-DICHLOROETHENE

1, 1-DICHLOROETHANE

CHLOROFORM (THM)

1, 1, 1-TRICHLOROETHANE

CARBON TETRACHLORIDE

1,2-DICHLOROETHANE

TRICHLOROETHENE

1,2-DICHLOROPROPANE

BROMODICHLOROMETHANE (THM)

CIS-1, 3-DICHLOROPROPENE

2-CHLOROETHYLVINYL ETHER

TRANS-1, 3-DICHLOROPROPENE

1, 1,2-TRICHLOROETHANE

TETRACHLOROETHENE

DIBROMOCHLOROMETHANE (THM)

CHLOROBENZENE

BROMOFORM (THM)

1, 1, 2, 2-TETRACHLOROETHANE

1,3-DICHLOROBENZENE

1,4-DICHLOROBENZENE

1,2-DICHLOROBENZENE

DICHLORODIFLUOROMETHANE

DILUTION FACTOR: 10 TIMES

PERCENT SURROGATE RECOVERY:

1,4-Dichlorobutane

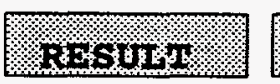

ND

ND

ND

ND

ND

ND

ND

ND

ND

ND

ND

ND

ND

ND

ND

ND

ND

ND

ND

ND

69,710

ND

ND

ND

ND

ND

MD

ND

ND

1208

\section{UOY TEST DATE}

UG/L

UG/L

UG/L

UG/L

UG/I

UG/L

UG/I

UG/L

UG/L

UG/L

UG/L

UG/L

UG $/ L$

UG/L

UG/L

UG/L

UG/L

UG/I

UG/L

UG/L

$U G / L$

UG/L

UG/L

UG/L

UG/L

UG/L

UG/L

UG/L

UG/L
$12 / 01 / 94$

$12 / 01 / 94$

$12 / 01 / 94$

$12 / 01 / 94$

$12 / 01 / 94$

$12 / 01 / 94$

$12 / 01 / 94$

$12 / 01 / 94$

$12 / 01 / 94$

$12 / 01 / 94$

$12 / 01 / 94$

$12 / 01 / 94$

$12 / 01 / 94$

$12 / 01 / 94$

$12 / 01 / 94$

$12 / 01 / 94$

$12 / 01 / 94$

$12 / 01 / 94$

$12 / 01 / 94$

$12 / 01 / 94$

$12 / 01 / 94$

$12 / 01 / 94$

$12 / 01 / 94$

$12 / 01 / 94$

$12 / 01 / 94$

$12 / 01 / 94$

$12 / 01 / 94$

$12 / 01 / 94$

$12 / 01 / 94$

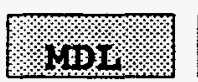

1.0

1.0

1.0

1.0

1.0

1.0

1.0

1.0

1.0

1.0

1.0

1.0

1.0

1.0

1.0

1.0

1.0

1.0

1.0

1.0

1.0

1.0

1. 0

1.0

1.0

1.0

1.0

1.0

1.0
Y154HOD

EPA 601 EPA 601

EPA 601

EPA 601

EPA 601

EPA 601

EPA 601

EPA 601

EPA 601

EPA 601

EPA 601

EPA 601

EPA 601

EPA 601

EPA 601

EPA 601

EPA 601

EPA 601

EPA 601

EPA 601

EPA 601

EPA 601

EPA 601

EPA 601

EPA 601

EPA 601

EPA 601

EPA 601

EPA 601

These results apply only to the actual sample as tested. The integrity of results is dependent upon the quality of the sampling technique and subsequent handling. Actual detection limits are the above reported MDL's multiplied by dilution factors, if any. American Environmental Laboratories, Inc. shall not be held liable for any interpretation of analytical results. 


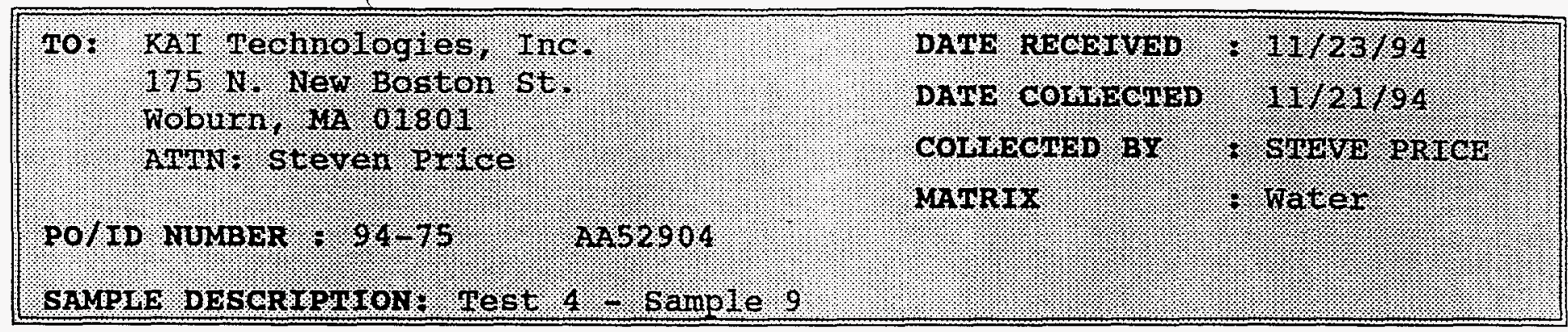

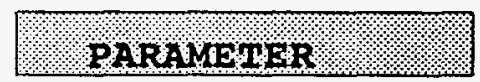

CHLOROMETHANE

VINYL CHLORIDE

BROMOMETHANE

CHLORETHANE

TRICHLOROFLUOROMETHANE

1, 1-DICHLOROETHENE

METHYLENE CHLORIDE

TRANS-1, 2-DICHLOROETHENE

1, 1-DICHLOROETHANE

CHLOROFORM (THM)

1, 1, 1-TRICHLOROETHANE

CARBON TETRACHLORIDE

1, 2-DICHLOROETHANE

TRICHLOROETHENE

1, 2-DICHLOROPROPANE

BROMODICHLOROMETHANE (THM)

CIS-1, 3-DICHLOROPROPENE

2-CHIOROETHYLVINYL ETHER

TRANS-1,3-DICHLOROPROPENE

$1,1,2$-TR ICHLOROETHANE

TETRACHLOROETHENE

DIBROMOCHLOROMETHANE (THM)

CHLOROBENZENE

BROMOFORM ( $T H M$ )

$1,1,2,2-T E T R A C H L O R O E T H A N E$

1,3-DICHLOROBENZENE

1, 4-DICHLOROBENZENE

1, 2-DICHLOROBENZENE

DICHLORODIFLUOROMETHANE

DILUTION FACTOR: 10 TIMES

PERCENT SURROGATE RECOVERY:

1,4-Dichlorobutane

- ANALYTICAL RESULTS -

\begin{tabular}{|c|c|}
\hline Rasuth & UOM \\
\hline ND & UG/L \\
\hline ND & $\mathrm{UG} / \mathrm{L}$ \\
\hline ND & $\mathrm{UG} / \mathrm{L}$ \\
\hline ND & UG/L \\
\hline ND & UG/L \\
\hline ND & $\mathrm{UG} / \mathrm{L}$ \\
\hline ND & UG/L \\
\hline ND & UG/L \\
\hline ND & UG/L \\
\hline ND & UG/L \\
\hline ND & UG/L \\
\hline ND & UG/L \\
\hline ND & UG/I \\
\hline ND & UG/L \\
\hline ND & $U G / L$ \\
\hline ND & UG/L \\
\hline ND & UG/L \\
\hline ND & UG/I \\
\hline ND & UG/L \\
\hline ND & $\mathrm{UG} / \mathrm{L}$ \\
\hline 87,290 & UG/L \\
\hline ND & UG/I \\
\hline ND & UG/L \\
\hline ND & UG/L \\
\hline ND & UG/L \\
\hline ND & $U G / I$ \\
\hline ND & $\mathrm{UG} / \mathrm{I}$ \\
\hline ND & UG/I \\
\hline ND & $U G / I$ \\
\hline
\end{tabular}

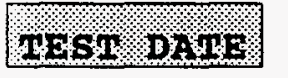

$12 / 01 / 94$

$12 / 01 / 94$

$12 / 01 / 94$

$12 / 01 / 94$

$12 / 01 / 94$

$12 / 01 / 94$

$12 / 01 / 94$

$12 / 01 / 94$

$12 / 01 / 94$

$12 / 01 / 94$

$12 / 01 / 94$

$12 / 01 / 94$

$12 / 01 / 94$

$12 / 01 / 94$

$12 / 01 / 94$

$12 / 01 / 94$

$12 / 01 / 94$

$12 / 01 / 94$

$12 / 01 / 94$

$12 / 01 / 94$

$12 / 01 / 94$

$12 / 01 / 94$

$12 / 01 / 94$

$12 / 01 / 94$

$12 / 01 / 94$

$12 / 01 / 94$

$12 / 01 / 94$

$12 / 01 / 94$

$12 / 01 / 94$

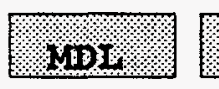

1.0

1.0

1.0

1.0

1.0

1.0

1.0

1.0

1.0

1.0

1.0

1.0

1.0

1.0

1. 0

1.0

1.0

1.0

1.0

1.0

1.0

1.0

1.0

1. 0

1.0

1.0

1. 0

1. 0

1.0
YITHHoD

EPA 601

EPA 601

EPA 601

EPA 601

EPA 601

EPA 601

EPA 601

EPA 601

EPA 601

EPA 601

EPA 601

EPA 601

EPA 601

EPA 601

EPA 601

EPA 601

EPA 601

EPA 601

EPA 601

EPA 601

EPA 601

EPA 601

EPA 601

EPA 601

EPA 601

EPA 601

EPA 601

EPA 601

EPA 601

These results apply only to the actual sample as tested. The integrity of results is dependent upon the quality of the sampling technique and subsequent handling. Actual detection limits are the above reported MDL's multiplied by dilution factors, if any. American Environmental Laboratories, Inc. shall not be held liable for any interpretation of analytical results. 


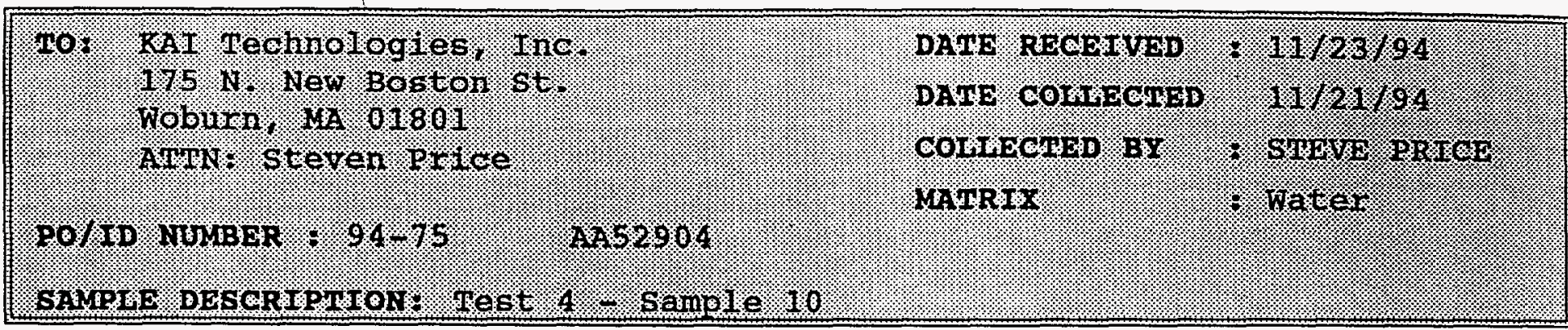

- ANALYTICAL RESULTS -

\section{PARAMTTER}

CHLOROMETHANE

VINYL CHLORIDE

BROMOMETHANE

CHLORETHANE

TRICHLOROFLUOROMETHANE

1,1-DICHLOROETHENE

METHYLENE CHLORIDE

TRANS-1,2-DICHLOROETHENE

1,1-DICHLOROETHANE

CHLOROFORM (THM)

1,1,1-TRICHLOROETHANE

CARBON TETRACHLORIDE

1,2-DICHLOROETHANE

TRICHLOROETHENE

1,2-DICHLOROPROPANE

BROMODICHLOROMETHANE (THM)

CIS-1, 3-DICHLOROPROPENE

2-CHLOROETHYLVINYL ETHER

TRANS-1, 3-DICHLOROPROPENE

1, 1, 2-TRICHLOROETHANE

TETRACHLOROETHENE

DIBROMOCHLOROMETHANE (THM)

CHLOROBENZENE

BROMOFORM (THM)

$1,1,2,2$-TETRACHLOROETHANE

1,3-DICHLOROBENZENE

1,4-DICHLOROBENZENE

1,2-DICHLOROBENZENE

DICHLORODIFIUOROMETHANE

DILUTION FACTOR: 10 TIMESS

PERCENT GURROGATE RECOVERY:

1,4-Dichlorobutane

\begin{tabular}{|c|c|}
\hline KassuLH & $00 \mathrm{x}$ \\
\hline ND & UG/L \\
\hline ND & UG/L \\
\hline ND & UG/L \\
\hline ND & UG/L \\
\hline ND & UG/L \\
\hline ND & UG/L \\
\hline ND & UG/L \\
\hline ND & UG/L \\
\hline ND & $U G / L$ \\
\hline ND & UG/L \\
\hline ND & $U G / I$ \\
\hline ND & UG/L \\
\hline ND & UG/L \\
\hline ND & UG/I \\
\hline ND & UG/L \\
\hline ND & UG/L \\
\hline ND & UG/L \\
\hline ND & UG/I \\
\hline ND & UG/I \\
\hline ND & UG/I \\
\hline 87,000 & UG/L \\
\hline ND & UG/I \\
\hline ND & UG/L \\
\hline ND & UG/L \\
\hline ND & UG/L \\
\hline ND & UG/L \\
\hline ND & UG/L \\
\hline ND & UG/I \\
\hline ND & UG/L \\
\hline
\end{tabular}

948

\section{TESTI BADI}

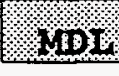

\section{$12 / 01 / 94$ \\ $12 / 01 / 94$ \\ $12 / 01 / 94$ \\ $12 / 01 / 94$ \\ $12 / 01 / 94$ \\ $12 / 01 / 94$}

$12 / 01 / 94$

$12 / 01 / 94$

$12 / 01 / 94$

$12 / 01 / 94$

$12 / 01 / 94$

$12 / 01 / 94$

$12 / 01 / 94$

$12 / 01 / 94$

$12 / 01 / 94$

$12 / 01 / 94$

$12 / 01 / 94$

$12 / 01 / 94$

$12 / 01 / 94$

$12 / 01 / 94$

$12 / 01 / 94$

$12 / 01 / 94$

$12 / 01 / 94$

$12 / 01 / 94$

$12 / 01 / 94$

$12 / 01 / 94$

$12 / 01 / 94$

$12 / 01 / 94$

$12 / 01 / 94$

1.0

1.0

1.0

1.0

1.0

1.0

1.0

1.0

1.0

1.0

1.0

1.0

1.0

1.0

1.0

1.0

1.0

1.0

1.0

1.0

1.0

1.0

1.0

1.0

1.0

1.0

1.0

1.0

1.0

\section{XEMHIOD}

EPA 601

EPA 601

EPA 601

EPA 601

EPA 601

EPA 601

EPA 601

EPA 601

EPA 601

EPA 601

EPA 601

EPA 601

EPA 601

EPA 601

EPA 601

EPA 601

EPA 601

EPA 601

EPA 601

EPA 601

EPA 601

EPA 601

EPA 601

EPA 601

EPA 601

EPA 601

EPA 601

EPA 601

EPA 601

These results apply only to the actual sample as tested. The integrity of results is dependent upon the quality of the sampling technique and subsequent handling. Actual detection limits are the above reported MDL's multiplied by dilution factors, if any. American Environmental Laboratories, Inc. shall not be held liable for any interpretation of analytical results. 


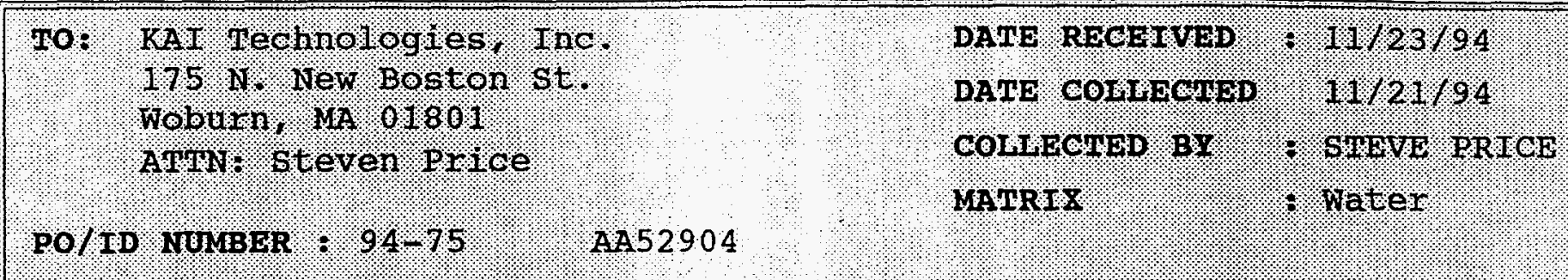

SAMPLE DESCRIPITON, Test 4 - Sample 11

PARQUEATER:

CHLOROMETHANE

VINYL CHLORIDE

BROMOMETHANE

CHLORETHANE

TRICHLOROFLUOROMETHANE

1,1-DICHLOROETHENE

METHYLENE CHLORIDE

TRANS-1,2-DICHLOROETHENE

1, 1-DICHLOROETHANE

CHLOROFORM (THM)

$1,1,1$-TRICHLOROETHANE

CARBON TETRACHLORIDE

1, 2-DICHLOROETHANE

TRICHLOROETHENE

1, 2-DICEIOROPROPANE

BROMODICHIOROMETHANE (THM)

CIS-1, 3-DICHLOROPROPENE

2-CHLOROETHYLVINYL ETHER

TRANS-1, 3-DICHLOROPROPENE

1, 1, 2-TRICHLOROETHANE

TETRACHLOROETHENE

DIBROMOCHLOROMETHANE (THM)

CHLOROBENZENE

BROMOFORM (THM)

1, 1, 2, 2-TETRACHLOROETHANE

1,3-DICHLOROBENZENE

$1,4-D I C H L O R O B E N Z E N E$

1,2-DICHLOROBENZENE

DICHLORODIFLUOROMETHANE

DILUTION FACTOR: 10 TIMES

PERCENT SURROGATE RECOVERY:

1,4-Dichlorobutane

- ANALYTICAL RESULTTS -

\begin{tabular}{|c|c|}
\hline RESULI & UOM \\
\hline ND & UG/L \\
\hline ND & UG/L \\
\hline ND & UG/L \\
\hline ND & UG/L \\
\hline ND & UG/L \\
\hline ND & UG/L \\
\hline ND & UG/I \\
\hline ND & UG/L \\
\hline ND & UG/L \\
\hline ND & UG/L \\
\hline ND & $\mathrm{UG} / \mathrm{L}$ \\
\hline ND & UG/L \\
\hline ND & UG/L \\
\hline ND & UG/L \\
\hline ND & UG/L \\
\hline ND & UG/L \\
\hline ND & $\mathrm{UG} / \mathrm{L}$ \\
\hline ND & $\mathrm{UG} / \mathrm{L}$ \\
\hline ND & $\mathrm{UG} / \mathrm{L}$ \\
\hline ND & UG/L \\
\hline 57,560 & UG/L \\
\hline ND & $\mathrm{UG} / \mathrm{L}$ \\
\hline ND & $\mathrm{UG} / \mathrm{L}$ \\
\hline ND & UG/L \\
\hline ND & UG/L \\
\hline ND & UG/L \\
\hline ND & UG/L \\
\hline ND & UG/L \\
\hline ND & UG/L \\
\hline
\end{tabular}

\section{TESH DAHD}

$12 / 02 / 94$

$12 / 02 / 94$

$12 / 02 / 94$

$12 / 02 / 94$

$12 / 02 / 94$

$12 / 02 / 94$

$12 / 02 / 94$

$12 / 02 / 94$

$12 / 02 / 94$

$12 / 02 / 94$

$12 / 02 / 94$

$12 / 02 / 94$

$12 / 02 / 94$

$12 / 02 / 94$

$12 / 02 / 94$

$12 / 02 / 94$

$12 / 02 / 94$

$12 / 02 / 94$

$12 / 02 / 94$

$12 / 02 / 94$

$12 / 02 / 94$

$12 / 02 / 94$

$12 / 02 / 94$

$12 / 02 / 94$

$12 / 02 / 94$

$12 / 02 / 94$

$12 / 02 / 94$

$12 / 02 / 94$

$12 / 02 / 94$

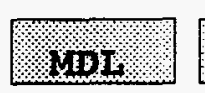

1.0

1.0

1.0

1.0

1.0

1.0

1.0

1.0

1.0

1.0

1.0

1.0

1.0

1.0

1.0

1.0

1.0

1.0

1.0

1.0

1.0

1.0

1.0

1.0

1.0

1.0

1.0

1.0

1.0

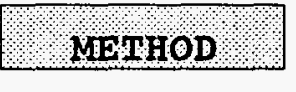

EPA 601

EPA 601

EPA 601

EPA 601

EPA 601

EPA 601

EPA 601

EPA 601

EPA 601

EPA 601

EPA 601

EPA 601

EPA 601

EPA 601

EPA 601

EPA 601

EPA 601

EPA 601

EPA 601

EPA 601

EPA 601

EPA 601

EPA 601

EPA 601

EPA 601

EPA 601

EPA 601

EPA 601

EPA 601

These results apply onty to the actual sample as tested. The integrity of results is dependent upon the quality of the sampling technique and subsequent handling. Actual detection limits are the above reported MDL's multiplied by dilution factors, if any. American Environmental Laboratories, Inc. shall not be held liable for any interpretation of analytical results. 


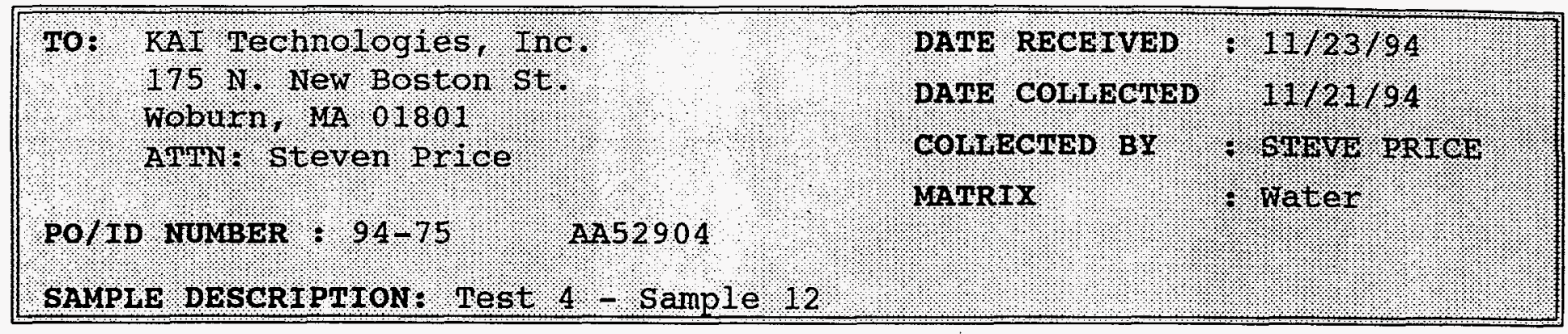

- ANALYTICAL RESULTSS -

PFARAMEMER

CHLOROMETHANE

VINYL CHLORIDE BROMOMETHANE CHLORETHANE TRICHLOROFIUOROMETHANE 1, 1-DICHLOROETHENE METHYLENE CHLORIDE TRANS-1, 2-DICHLOROETHENE 1,1-DICHLOROETHANE CHLOROFORM (THM)

$1,1,1$-TRICHLOROETHANE CARBON TETRACHLORIDE 1, 2-DICHLOROETHANE TRICHLOROETHENE . 1, 2-DICHLOROPROPANE BROMODICHLOROMETHANE (THM) CIS-1, 3-DICHLOROPROPENE 2-CHLOROETHYLVINYL ETHER TRANS-1, 3-DICHLOROPROPENE $1,1,2$-TRICHLOROETHANE TETRACHLOROETHENE DIBROMOCHLOROMETHANE (THM) CHLOROBENZENE BROMOFORM (THM)

$1,1,2,2$-TETRACHLOROETHANE 1,3-DICHLOROBENZENE 1, 4-DICHLOROBENZENE 1,2-DICHLOROBENZENE DICHLORODIFLUOROMETHANE DILUTION FACTOR: 10 TIMES PERCENT SURROGATE RECOVERY : 1,4-Dichlorobutane

\begin{tabular}{ll}
\hline RESULT & UOOM \\
\cline { 2 - 2 } ND & UG/L \\
ND & UG/L \\
ND & UG/L \\
ND & UG/L \\
ND & UG/L \\
ND & UG/L \\
ND & UG/L \\
ND & UG/L \\
ND & UG/L \\
ND & UG/L \\
ND & UG/L \\
ND & UG/L \\
ND & UG/L \\
ND & UG/L \\
ND & UG/L \\
ND & UG/L \\
ND & UG/L \\
ND & UG/L \\
ND & UG/L \\
ND & UG/L \\
69, 440 & UG/L \\
ND & UG/L \\
ND & UG/L \\
ND & UG/L \\
ND & UG/L \\
ND & UG/L \\
ND & UG/L \\
ND & UG/L \\
ND & UG/L \\
&
\end{tabular}

908

\section{TEST DATE}

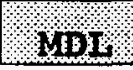

METHOD

$\begin{array}{ll}\text { EPA } & 601 \\ \text { EPA } & 601 \\ \text { EPA } & 601 \\ \text { EPA } & 601 \\ \text { EPA } & 601 \\ \text { EPA } & 601 \\ \text { EPA } & 601 \\ \text { EPA } & 601 \\ \text { EPA } & 601 \\ \text { EPA } & 601 \\ \text { EPA } & 601 \\ \text { EPA } & 601 \\ \text { EPA } & 601 \\ \text { EPA } & 601 \\ \text { EPA } & 601 \\ \text { EPA } & 601 \\ \text { EPA } & 601 \\ \text { EPA } & 601 \\ \text { EPA } & 601 \\ \text { EPA } & 601 \\ \text { EPA } & 601 \\ \text { EPA } & 601 \\ \text { EPA } & 601 \\ \text { EPA } & 601 \\ \text { EPA } & 601 \\ \text { EPA } & 601 \\ \text { EPA } & 601 \\ \text { EPA } & 601 \\ \text { EPA } 601\end{array}$

These results apply only to the actual sampie as tested. The integrity of results is dependent upon the quality of the sampling technique and subsequent handling. Actual detection fimits are the above reported MDL's multiplied by dilution factors, if any. American Environmental Laboratories, Inc. shall not be held liable for any interpretation of analytical results. 


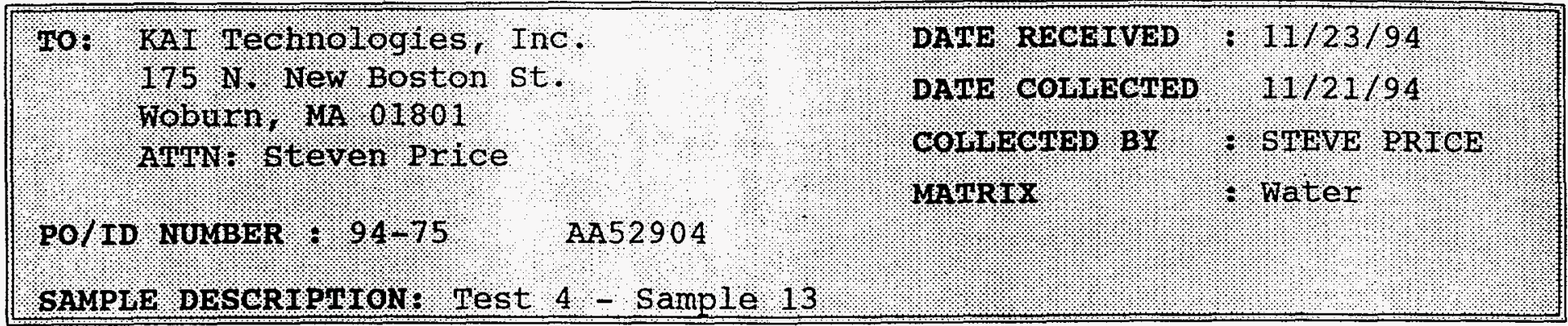

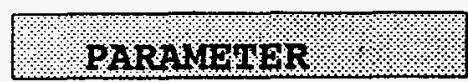

CHLOROMETHANE VINYL CHLORIDE BROMOMETHANE CHLORETHANE TRICHLOROFLUOROMETHANE 1,1-DICHLOROETHENE METHYLENE CHLORIDE TRANS-1, 2-DICHLOROETHENE 1, 1-DICHLOROETHANE CHLOROFORM (THM) 1, 1, 1-TRICHLOROETHANE CARBON TETRACHLORIDE 1,2-DICHLOROETHANE TRICHLOROETHENE 1,2-DICHLOROPROPANE BROMODICHLOROMETHANE (THM) CIS-1 , 3-DICHLOROPROPENE 2-CHLOROETHYLVINYL ETHER TRANS-1, 3-DICHLOROPROPENE 1, 1,2-TRICHLOROETHANE TETRACHLOROETHENE DIBROMOCHLOROMETHANE (THM) CHLOROBENZENE BROMOFORM (THM)

$1,1,2,2$-TETRACHLOROETHANE

1,3-DICHLOROBENZENE

1, 4-DICHLOROBEN ZENE

1,2-DICHLOROBENZENE DICHLORODIFLUOROMETHANE DILUTION FACTOR: 10 TIMES PERCENT SURROGATE RECOVERY: 1,4-Dichlorobutane
- ANALYTICAL RESULTS -

\begin{tabular}{l|l}
\hline RESULT & UOM \\
\cline { 2 - 2 } ND & UG/L \\
ND & UG/L \\
ND & UG/L \\
ND & UG/L \\
ND & UG/L \\
ND & UG/L \\
ND & UG/L \\
ND & UG/L \\
ND & UG/L \\
ND & UG/L \\
ND & UG/L \\
ND & UG/L \\
ND & UG/L \\
ND & UG/L \\
ND & UG/L \\
ND & UG/L \\
ND & UG/L \\
ND & UG/L \\
ND & UG/L \\
ND & UG/L \\
60, 280 & UG/L \\
ND & UG/L \\
ND & UG/L \\
ND & UG/L \\
ND & UG/L \\
ND & UG/L \\
ND & UG/L \\
ND & UG/L \\
ND & UG/L \\
&
\end{tabular}

\section{MESH DAMU}
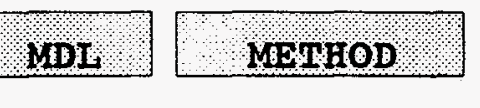

$12 / 02 / 94$

1.0

EPA 601

$12 / 02 / 94$

1.0

$12 / 02 / 94 \quad 1.0$

EPA 601

$12 / 02 / 94$

1.0

$12 / 02 / 94$

1.0

$12 / 02 / 94$

1.0

$12 / 02 / 94$

1.0

$12 / 02 / 94$

$12 / 02 / 94$

$12 / 02 / 94$

$12 / 02 / 94$

$12 / 02 / 94$

$12 / 02 / 94$

$12 / 02 / 94$

$12 / 02 / 94$

$12 / 02 / 94$

$12 / 02 / 94$

$12 / 02 / 94$

$12 / 02 / 94$

$12 / 02 / 94$

$12 / 02 / 94$

$12 / 02 / 94$

$12 / 02 / 94$

$12 / 02 / 94$

$12 / 02 / 94$

$12 / 02 / 94$

$12 / 02 / 94$

$12 / 02 / 94$

1.0

1.0

1.0

1.0

EPA 601

EPA 601

EPA 601

EPA 601

EPA 601

EPA 601

EPA 601

EPA 601

1.0

EPA 601

1.0

1.0

1.0

1.0

1.0

1.0

1.0

1.0

1.0

1.0

1.0

1.0

1.0

1.0

1.0

1.0

$12 / 02 / 94$

1.0

EPA 601

EPA 601

EPA 601

EPA 601

EPA 601

EPA 601

EPA 601

EPA 601

EPA 601

EPA 601

EPA 601

EPA 601

EPA 601

EPA 601

EPA 601

EPA 601

EPA 601

EPA 601 


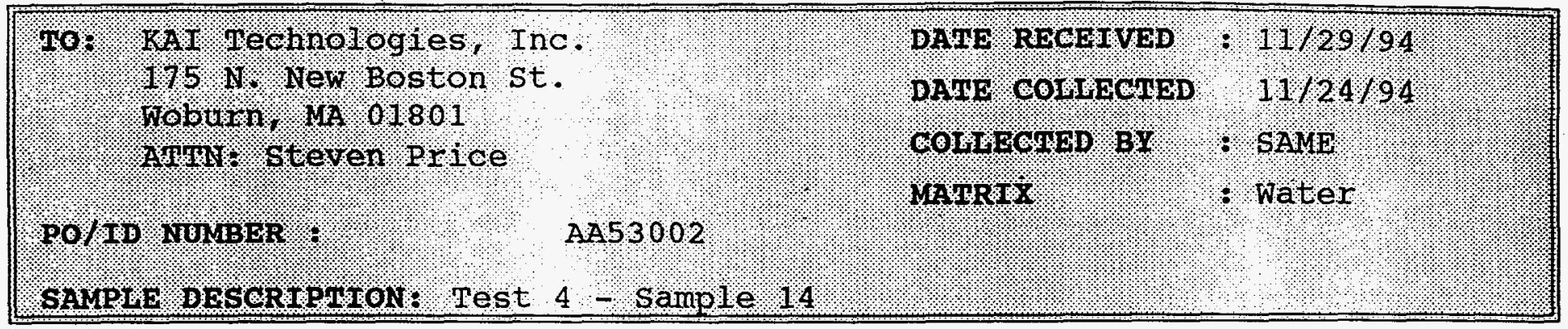

- ANALYTICAL RESULTS -

\section{PARALIEAER:}

CHLOROMETHANE

VINYL CHLORIDE

BROMOMETHANE

CHLORETHANE

TRICHLOROFLUOROMETHANE

1,1-DICHLOROETHENE

METHYLENE CHLORIDE

TRANS-1, 2-DICHLOROETHENE

1,1-DICHLOROETHANE

CHLOROFORM (THM)

1,1,1-TRICHLOROETHANE

CARBON TETRACHLORIDE

1,2-DICHLOROETHANE

TRICHLOROETHENE

1,2-DICHLOROPROPANE

BROMODICHLOROMETHANE (THM)

CIS-1, 3-DICHLOROPROPENE

2-CHLOROETHYLVINYL ETHER

TRANS-1, 3-DICHLOROPROPENE

1, 1,2-TRICHLOROETHANE

TETRACHLOROETHENE

DIBROMOCHLOROMETHANE (THM)

CELOROBENZENE

BROMOFORM (THM)

$1,1,2,2$-TETRACHLOROETHANE

1, 3-DICHLOROBENZENE

1,4-DICHLOROBENZENE

1,2-DICHLOROBENZENE

DICHLORODIFLUOROMETHANE

DILUTION FACTOR: 10 TIMES

PERCENT SURROGATE RECOVERY:

1,4-Dichlorobutane

\begin{tabular}{|c|c|}
\hline RESULT & 10 \\
\hline ND & UG/I \\
\hline ND & $\mathrm{UG} / \mathrm{L}$ \\
\hline ND & $U G / I$ \\
\hline ND & $\mathrm{UG} / \mathrm{L}$ \\
\hline ND & $\mathrm{UG} / \mathrm{L}$ \\
\hline ND & UG/L \\
\hline ND & UG/L \\
\hline ND & UG/L \\
\hline ND & $\mathrm{UG} / \mathrm{I}$ \\
\hline ND & UG/I \\
\hline ND & UG/工 \\
\hline ND & UG/I \\
\hline ND & UG/L \\
\hline ND & UG/L \\
\hline ND & UG/L \\
\hline ND & UG/I \\
\hline ND & UG/L \\
\hline ND & UG/L \\
\hline ND & UG/L \\
\hline ND & UG/L \\
\hline 39,310 & UG/I \\
\hline ND & UG/L \\
\hline ND & UG/L \\
\hline ND & UG/L \\
\hline ND & UG/L \\
\hline ND & UG/L \\
\hline ND & UG/L \\
\hline ND & UG/L \\
\hline ND & UG/L \\
\hline
\end{tabular}

908

\section{TEST DATE}

MBI

$12 / 02 / 94$

$12 / 02 / 94$

$12 / 02 / 94$

$12 / 02 / 94$

$12 / 02 / 94$

$12 / 02 / 94$

$12 / 02 / 94$

$12 / 02 / 94$

$12 / 02 / 94$

$12 / 02 / 94$

$12 / 02 / 94$

$12 / 02 / 94$

$12 / 02 / 94$

$12 / 02 / 94$

$12 / 02 / 94$

$12 / 02 / 94$

$12 / 02 / 94$

$12 / 02 / 94$

$12 / 02 / 94$

$12 / 02 / 94$

$12 / 02 / 94$

$12 / 02 / 94$

$12 / 02 / 94$

$12 / 02 / 94$

$12 / 02 / 94$

$12 / 02 / 94$

$12 / 02 / 94$

$12 / 02 / 94$

$12 / 02 / 94$

1.0

1.0

1.0

1.0

1.0

1.0

1.0

1.0

1.0

1.0

1.0

1.0

1.0

1.0

1.0

1.0

1.0

1.0

1.0

1.0

1.0

1.0

1.0

1.0

1.0

1.0

1.0

1.0

1.0
METHOD

\section{EPA 601}

EPA 601

EPA 601

EPA 601

EPA 601

EPA 601

EPA 601

EPA 601

EPA 601

EPA 601

EPA 601

EPA 601

EPA 601

EPA 601

EPA 601

EPA 601

EPA 601

EPA 601

EPA 601

EPA 601

EPA 601

EPA 601

EPA 601

EPA 601

EPA 601

EPA 601

EPA 601

EPA 601

EPA 601

These results apply only to the actual sample as tested. The integrity of results is dependent upon the quality of the sampling technique and subsequent handling. Actual detection limits are the above reported MDL's multiplied by dilution factors, if any. American Environmental Laboratories, Inc. shall not be held liable for any interpretation of analytical results. 


\section{APPENDIX B}

Assaigai Analytical Laboratory Data on Cold Plasma Products 


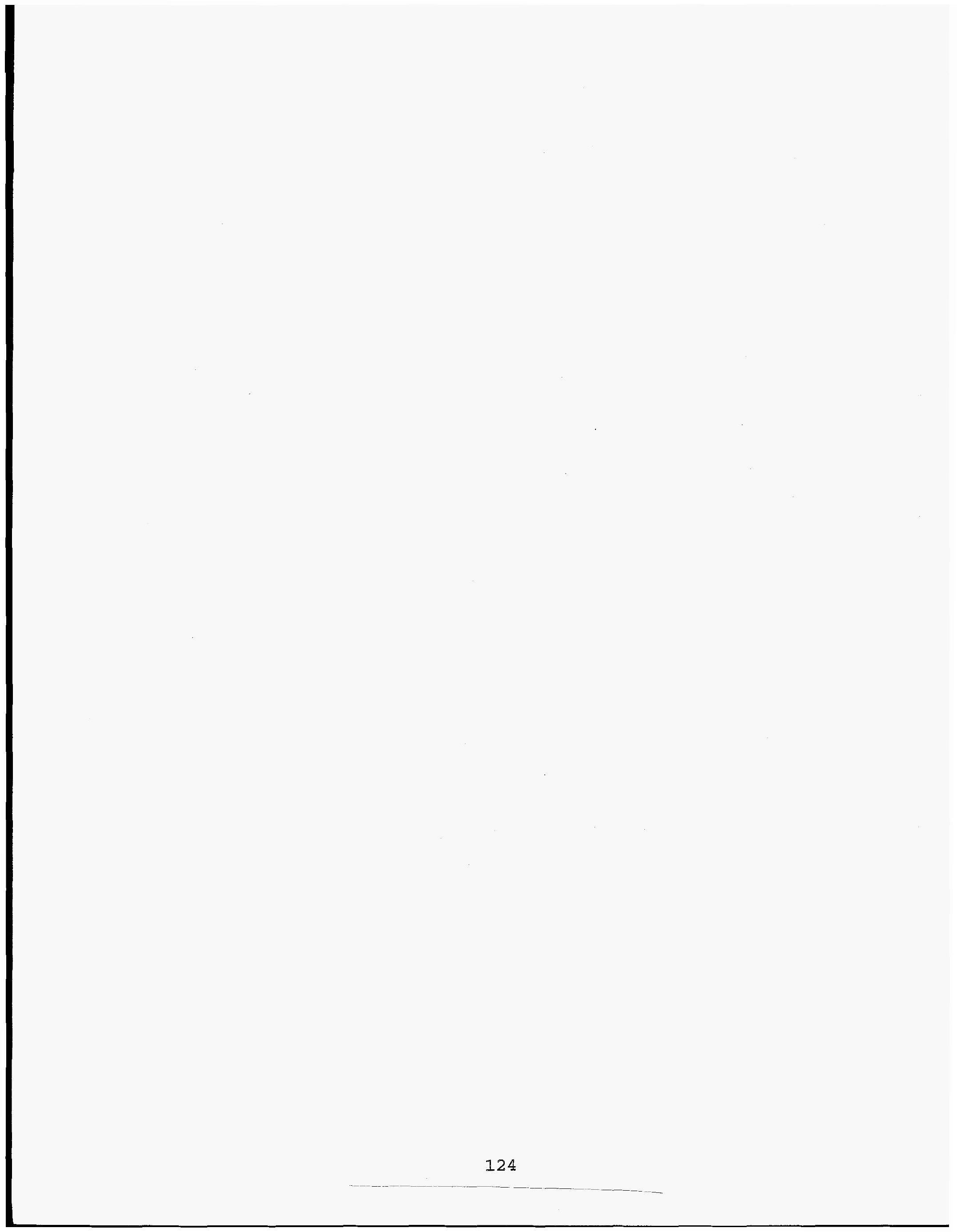


Report Generated:

November 7, 1994 14:21 CERTIFICATE OF ANALYSIS RESULTS BY SAMPLE

\section{SENT ADHERENT TECHNOLOGIES \\ TO: 11208 COCHITI SE \\ ALBUQUERQUE, NM 87123}

ATTN : R. ALLRED

\author{
WORKORDER \# : 9410229 \\ WORK ID : INITAL TEST \\ CLIENT CODE : ADH01 \\ DATE RECEIVED : 10/25/94
}

Page: 1

Lab ID: $9410229-01 \mathrm{~A}$

Sample ID: INITAL TEST

Collected: $10 / 24 / 94 \quad 16: 12: 00$

Matrix: LIQUID

TEST / METHOD $\quad$ RESULT $\quad$ UNITS IIMIT D_F DATE BATCH_ID

SVOA LIB SRCH/20 PKS/GCMS

SVOA WATER SCAN/SW846 8270

n-Nitrosodimethylamine

Pyridine

Aniline

bis(2-Chloroethyl) Ether

2-Chloroplienol

1,3-Dichlorobenzene

1.4-Dichlorobenzene

Plienol

1,2-Dichlorobenzene

Benzyl Alcohol

his(2-Chloroisopropyl) Ether

2-Methylphenol / O-Cresol

Hexachloroethane

n-Nitroso-di-n-propylamine

Nitrobenzene

3/4 Methylphenol / M/P-Cresol

Isophorone

2-Nitrophenol

his(2-Chloroethoxy) Methane

2.4-Dimethylphenol

1.2.4-Trichlorobenzene

Napluthalene

Benzoic Acid

2.4-Dichlorophenol

4-Chloroaniline

Hexachlorobutadiene

2-Mellyylnaplithalene

4-Chloro-3-methylphenol

Hexachlorocyclopentadiene

2.4.6-Trichlorophenol

2,4.5-Trichlorophenol

2-Chloronapithalene

2-Nitroaniline

Acenaphthylene

Dimethylphthalate

2.6-Dinitrotoluene

Acenaphihene

3-Nitroaniline

Dibenzofuran

2.4-Dinitrotoluene

Fluorene

4-Chlorophenyl-phenylether

Diethylphthalate

\begin{tabular}{|c|c|c|c|c|}
\hline ND & ug/L & 1.0 & 10 & $11 / 02 / 94$ \\
\hline ND & $\mathrm{ug} / \mathrm{L}$ & 1.0 & 10 & $11 / 02 / 94$ \\
\hline ND & ug/L & 1.0 & 10 & $1 / / 02 / 94$ \\
\hline ND & ug $/ \mathrm{L}$ & 1.0 & 10 & $11 / 02 / 94$ \\
\hline 74000 & ug $/ \bar{L}$ & 1.0 & 10 & $11 / 02 / 94$ \\
\hline 26000 & ug $/ \mathrm{L}$ & 1.0 & 10 & $11 / 02 / 94$ \\
\hline 76000 & ug/L & 1.0 & 10 & $11 / 02 / 94$ \\
\hline ND & $\mathrm{ug} / \mathrm{L}$ & 1.0 & 10 & $11 / 02 / 94$ \\
\hline 720000000 & ug/L & 1.0 & 1000 & $11 / 02 / 94$ \\
\hline ND & ug/L & 1.0 & 10 & $11 / 02 / 94$ \\
\hline ND & $u g / L$ & 1.0 & 10 & $11 / 02 / 94$ \\
\hline ND & ug/L & 1.0 & 10 & $11 / 02 / 94$ \\
\hline 35000 & $\mathrm{ug} / \mathrm{L}$ & 1.0 & 10 & $11 / 02 / 94$ \\
\hline ND & ug/L & 1.0 & 10 & $11 / 02 / 94$ \\
\hline ND & ug/L & 1.0 & 10 & $11 / 02 / 94$ \\
\hline ND & ug $/ \mathrm{L}$ & 2.0 & 10 & $11 / 02 / 94$ \\
\hline ND & ug/L & 1.0 & 10 & $11 / 02 / 94$ \\
\hline ND & $\mathrm{ug} / \mathrm{L}$. & 1.0 & 10 & $11 / 02 / 94$ \\
\hline ND & ug/L & 1.0 & 10 & $11 /(02 / 94$ \\
\hline ND & $\mathrm{ug} / \mathrm{L}$ & 1.0 & 10 & $11 / 02 / 94$ \\
\hline 18000000 & ug $/ \mathrm{L}$ & 1.0 & 10 & $11 / 02 / 94$ \\
\hline ND & ug/L & 1.0 & 10 & $11 / 02 / 94$ \\
\hline ND & ug/L & 1.0 & 10 & $11 / 02 / 94$ \\
\hline 32000 & $\mathrm{ug} / \mathrm{L}$ & 1.0 & 10 & $11 / 02 / 94$ \\
\hline ND & ug/L & 1.0 & 10 & $11 / 02 / 94$ \\
\hline ND & ug/L & 1.0 & 10 & $11 / 02 / 94$ \\
\hline ND & $\mathrm{ug} / \mathrm{L}$ & 1.0 & 10 & $11 / 02 / 94$ \\
\hline ND & ug/L & 1.0 & 10 & $11 / 02 / 94$ \\
\hline ND & ug/L & 1.0 & 10 & $11 / 02 / 94$ \\
\hline ND & ug $/ \mathrm{L}$ & 1.0 & 10 & $11 / 02 / 94$ \\
\hline ND & ug/L & 1.0 & 10 & $11 / 02 / 94$ \\
\hline ND & ug $/ \mathrm{L}$ & 1.0 & 10 & $11 / 02 / 94$ \\
\hline ND & ug/L & 1.0 & 10 & $11 / 02 / 94$ \\
\hline ND & ug/L & 1.0 & 10 & $11 / 02 / 94$ \\
\hline ND & ug/L & 1.0 & 10 & $11 / 02 / 94$ \\
\hline ND & ug/L & 1.0 & 10 & $11 / 02 / 94$ \\
\hline ND & ug/L & 1.0 & 10 & $11 / 02 / 94$ \\
\hline ND & $\mathrm{ug} / \mathrm{L}$ & 1.0 & 10 & $11 / 02 / 94$ \\
\hline ND & $u g / L$ & 1.0 & 10 & $11 / 02 / 94$ \\
\hline ND & ug/L & 1.0 & 10 & $11 / 02 / 94$ \\
\hline ND & $\mathrm{ug} / \mathrm{L}$ & 1.0 & 10 & $11 / 02 / 94$ \\
\hline ND & $u g / L$ & 1.0 & 10 & $11 / 02 / 94$ \\
\hline ND & $\mathrm{ug} / \mathrm{L}$ & 1.0 & 10 & $11 / 02 / 94$ \\
\hline
\end{tabular}

WMSSVOA-099

WMSSVOA-099

WMSSVOA-099

WMSSVOA-099

WMSSVOA-099

WMSSVOA-099

WMSSVOA-099

WMSSVOA-099

WMSSVOA-099

WMSSVOA-099

WMSSVOA-099

WMSSVOA-099

WMSSVOA-099

WMSSVOA-099

WMSSVOA-099

WMSSVOA-099

WMSSVOA-099

WMSSVO $A-099$

WMSSVOA-099

WMSSVOA-099

WMSSVOA-099

WMSSVOA-099

WMSSVOA-099

WMSSVOA-099

WMSSVOA-099

WMSSVOA-099

WMSSVOA-099

WMSSVOA-099

WMSSVOA-099

WMSSVOA-099

WMSSVOA-099

WMSSVOA-099

WMSSVOA-099

WMSSVOA-099

WMSSVOA-099

WMSSVOA-099

WMSSVOA-099

WMSSVOA-099

WMSSVOA-099

WMSSVOA-099

WMSSVOA-099

WMSSVOA-099

WMSSVOA-099 
Page : 2

Lab ID: $9410229-01 A$

Sample ID: INITAL TEST

Collected: $10 / 24 / 94 \quad 16: 12: 00$

Matrix: LIQUID

TEST / METHOD RESULT UNITS LIMIT D_F DATE BATCH_ID

SVOA WATER SCAN/SW846 8270

4-Nitrophenol

4.6-Dinitro-2-methylphenol

n-Nitrosodiphenylamine

4-Nitroaniline

4-Bromophenyl-phenylether

Hexachlorobenzene

Pentachlorophenol

2,4-Dinitrophenol

Benzidine

Plienanthrene

Anthracene

Di-n-butylphthalate

Fluoranthene

Pyrene

Butylbenzylphthalate

Benzo(a)anthracene

Chrysene

3, $3^{\circ}$-Dichlorobenzidine

bis(2-Ethylliexyl)phthalate

Di-n-octyl phthalate

Benzo(b)fluoranthene

Benzo(k)fluoranthene

Benzo(a)pyrene

Indeno(1,2,3-cd)pyrene

Benzo(g,h,i)perylene

SVOA WT SCAN XT/SW846 3520

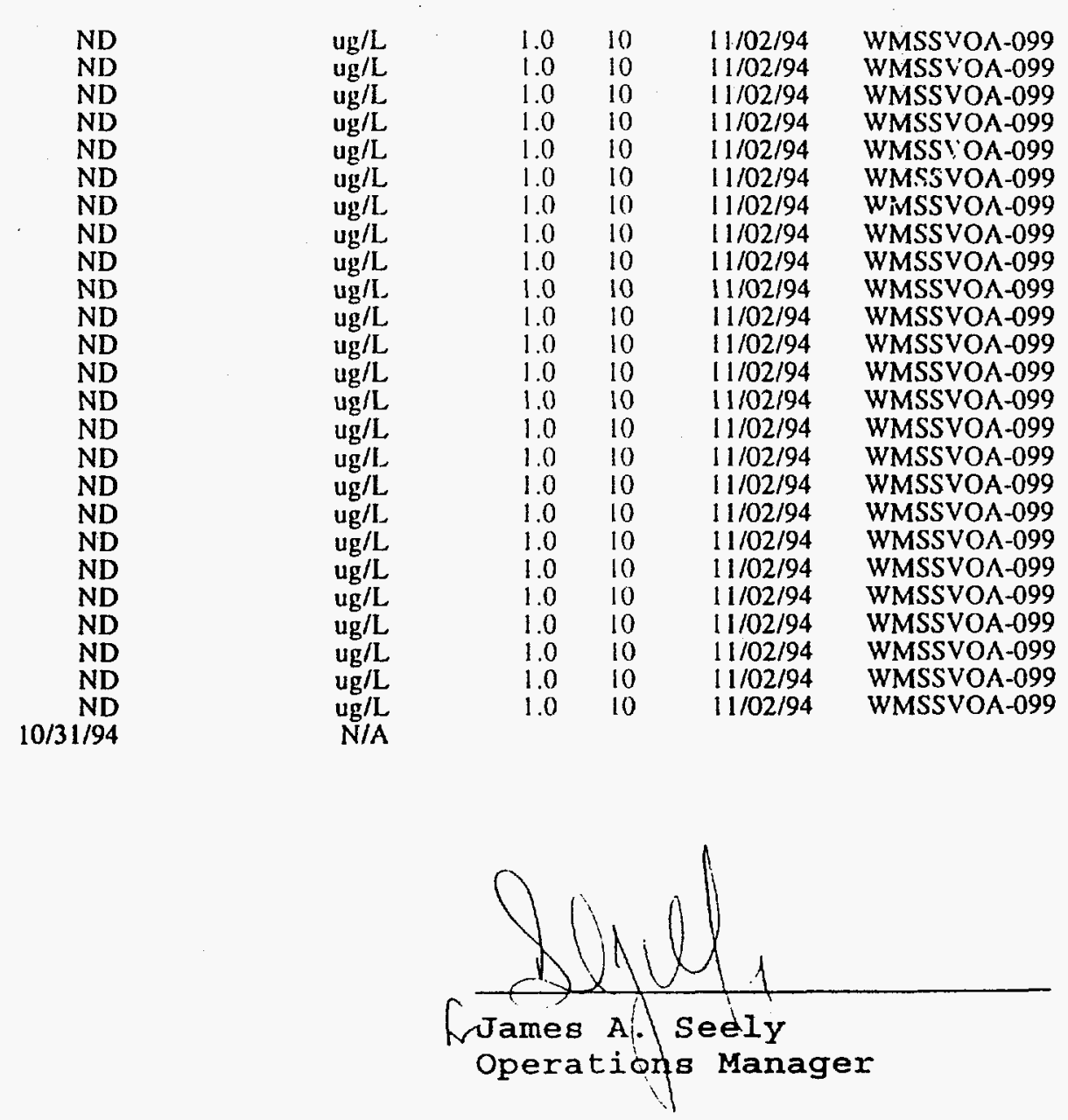




\section{APPENDIX C}

Ohio DSI Asbestos Data 
128 


\section{LABORATORY REPORT}

\section{Bulk Sample Aralysis For Asbestos by Polarized Light Microscopy}

Client DSI industries Consolidated, Inc.

Project Reference:

METCKAI Site Reference:

DSI Provided

Date Anatyzed:

October 4, 1994

Laboratory ID Number.

L1100222

Page: 1

Client Sample

Bulk

Macroscopic

Examination:

Color.

White

Texture:

Homogeneous:

Gross Description:

Fluffy

$Y$

Pipe Lagging

Components:

Asbestos Minerals

$\%$ Chrysotile

35

\% Amosite

30

$\%$ Crocidolite

\% Tremolite

\% Actinolite

\% Anthophylitite

Total \% Asbestos:

Other Component Materials

$\%$ Cellulose

\% Mineral Wool

\% Fibrous Glass

\% Hair

\% Symthetic Fibers

$\%$ Oiner Fibers

* Resinbinder

* Other Comoonents

Analysts Notes \& Comments:

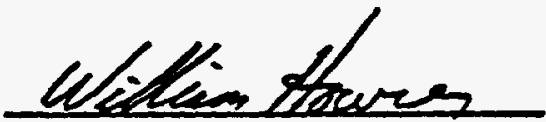

Wiliam D. Howser

Microscopist

No = Not Delected, trace a of

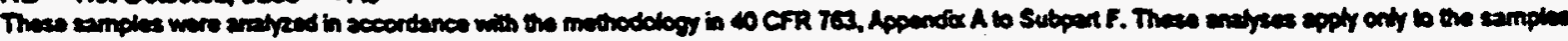
exaland

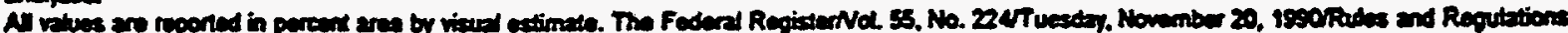

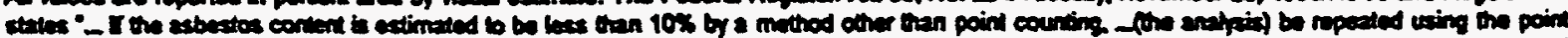

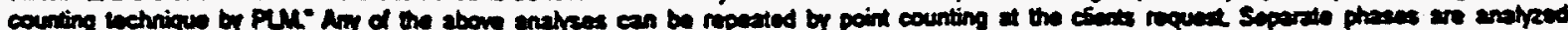
indridualy and reported as a combinad averees. 


\section{LABORATORY REPORT \\ Bulk Sample Analysis For Asbestos by Polarized Light Microscopy}

Client: DSI industries Consolidated, Inc.

Site Reference:

DSI Provided

Laboratory ID Number.
L1100222
Project Reference:

Date Analyzed:

METCKAI

October 4, 1994

Page: 1

Client Sample

G-1-8

G-1-10

G-1-11

G-1-12

Macroscopic

Examination:

Color:

Texture:

Homogeneous:

Gross Description:

\section{Brown/Green \\ Amorphous \\ $Y$}

Fillered

Product

\section{Brown/Green \\ Amorphous \\ $Y$}

Filtered

Product

\section{Brown/Green \\ Amorphous \\ $Y$}

Filtered

Product
Brown/Green

Amorphous

$Y$

Filtered

Product

\section{Components:}

Asbestos Minerals

\% Chrysotile

$\%$ Amosite

\% Crocidolite

* Tremolite

* Actinolite

* Anthophyllite

Total \% Asbestos:

Other Component Materials

* Cellulose

\% Mineral Wool

* Fibrous Glass

\% Hair

* Synthetic Fibers

\% Other Fibers

\% ResinBinder

\% Other Components

ND

ND

ND

ND

Analysts Notes \& Comments:

2

1

1

2

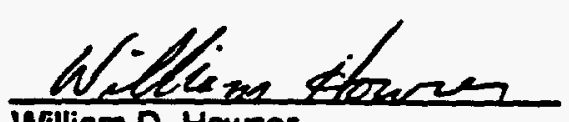

William D. Howser

Microscopist

ND $=$ Not Defected, trace $=<1 \%$

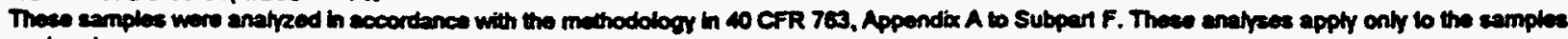
andized.

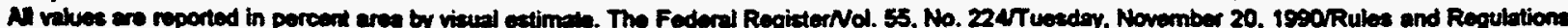

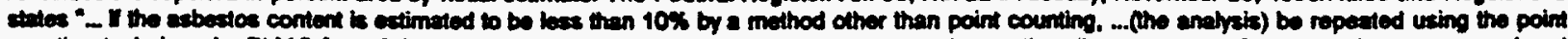

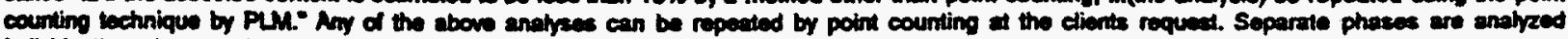
individualy and reported as a combinad sereme. 


\section{LABORATORY REPORT \\ Bulk Sample Analysis For Asbestos by Polarized Light Microscopy}

Client: DSI Industries Consolidated, Inc.

Project Reference:

METC/KAI

Site Reference:

DSI Provided

Date Analyzed:

October 4, 1994

Laboratory ID Number.

L1100222

Page: 1

Client Sample \#

GS-1-13

GS-1-14

GS-1-15

GS-1-16

Macroscopic

Examination:

Color.

Texture:

Homogeneous:

Gross Description:

\author{
BrownGreen \\ Amorphous \\ $Y$ \\ Filtered \\ Product
}

\section{Brown/Green \\ Amorphous \\ $Y$ \\ Brown/Green \\ Amorphous \\ $Y$}

Filtered

Product
Filtered

Product
Brown/Green

Amorphous

$Y$

Fitlered

Product

\section{Components:}

Asbestos Minerals

\% Chrysotile

\% Amosite

\% Crocidolite

\% Tremolite

\% Actinolite

\% Anthophyllite

Total \% Asbestos:

ND

ND

ND

ND

Other Component Materials

\% Cellulose

\% Mineral Wool

* Fibrous Glass

\% Hair

\% Synthetic Fibers

\% Other Fibers

\% Resin/Binder

\% Other Components

2

1

2

2

Analysts Notes \& Comments:

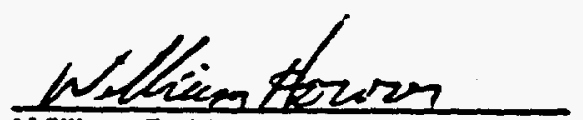

William D. Howser

Microscopist

ND $=$ Not Detected, trace $=4 \%$

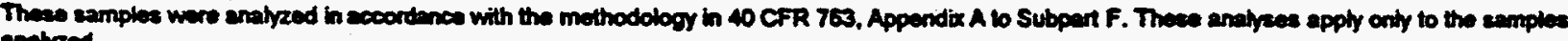
encilyzed.

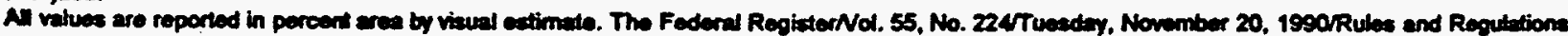

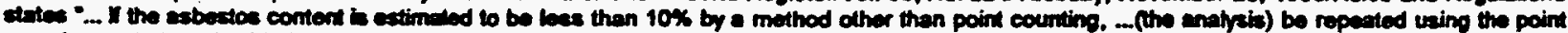
counting tochnique by PUM:- Am of the sbove analyses can be repeated by point counting at the clients request. Separmte phases are anelyzed individualty and reporiod as a comitined surege. 


\section{LABORATORY REPORT \\ Bulk Sample Analysis For Asbestos by Polarized Light Microscopy}

Client: DSI Industries Consolidated, Inc.

Project Reference:

METC/KAI

Site Reference:

DSI Provided

Date Analyzed:

October 4, 1994

Laboratory ID Number.

L1100222

Page: 1

Client Sample \#

G-1-17

G-1-18

G-1-18

G-1-20

Macroscopic

Examination:

Color:

Texture:

Homogeneous:

Gross Description:

$\begin{array}{cc}\text { Brown/Green } & \text { Brown/Green } \\ \text { Amorphous } & \text { Amorphous } \\ Y & Y \\ \text { Filtered } & \text { Filtered } \\ \text { Product } & \text { Product }\end{array}$

$\begin{array}{cc}\text { Brown/Green } & \text { Brown/Green } \\ \text { Amorphous } & \text { Amorphous } \\ \text { Y } & Y \\ \text { Filtered } & \text { Filtered } \\ \text { Product } & \text { Product }\end{array}$

Components:

Asbestos Minerals

\% Chrysotile

$\%$ Amosite

$\%$ Crocidolite

\% Tremolite

$\%$ Actinolite

$\%$ Anthophyllite

Total \% Asbestos:

ND

ND

ND

ND

Other Component Materials

$\%$ Cellulose

2

3

2

2

\% Mineral Wool

\% Fibrous Glass

\% Hair

\% Synthetic Fibers

\% Other Fibers

\% Resin/Binder

\% Other Components

98

97

98

Analysts Notes \& Comments:

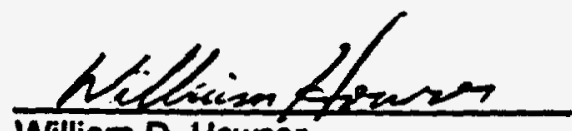

William D. Howser

Microscopist

ND $=$ Nol Detected, trace $=<1 \%$

These samples were analyzed in sceordance with the metrodecy in 40 CFR 763, Appendix A to Subpert F. These enalyees apply ondy bo the samples maliped.

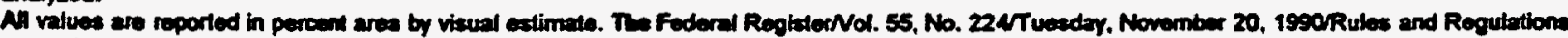

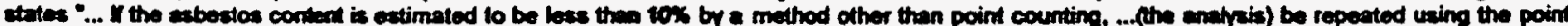

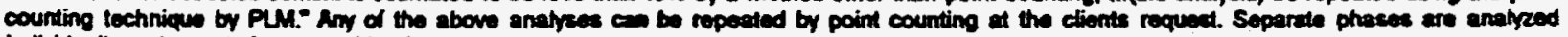
Indinidually and reported as ecombined awerepe. 


\section{LABORATORY REPORT \\ Bulk Sample Analysis For Asbestos by Polarized Light Microscopy}

Client: DSI Industries Consolidated, Inc.

Site Reference: $\quad$ DSI Provided

Project Reference:

METCKAI

Laboratory ID Number.

L1100222

Date Analyzed: October 4, 1994

Page: 1

Cient Sample \#

G-1-21

G-1-22

G-1-23

G-1-24

Macroscopic

Examination:

Color.

Texture:

Homogeneous:

Gross Description:

$\begin{array}{cc}\text { BrownGreen } & \text { Brown/Green } \\ \text { Amorphous } & \text { Amorphous } \\ Y & Y \\ \text { Filtered } & \text { Filtered } \\ \text { Product } & \text { Product }\end{array}$

\begin{tabular}{|c|c|}
\hline $\begin{array}{c}\text { Brown/Green } \\
\text { Amorphous } \\
\text { Y } \\
\text { Filtered } \\
\text { Product }\end{array}$ & $\begin{array}{c}\text { Brown/Green } \\
\text { Amorphous } \\
\text { Y } \\
\text { Filtered } \\
\text { Product }\end{array}$ \\
\hline
\end{tabular}

Components:

Asbestos Minerals

\% Chrysotile

* Amosite

* Crocidolite

* Tremolite

* Actinolite

\% Anthophyllite

Total \% Asbestos:

ND

ND

ND

ND

Other Component Materials

* Cellulose

\% Mineral Wool

* Fibrous Glass

X Hair

* Synthetic Fibers

* Other Fibers

\% Resin/Binder

* Other Components

Analysts Notes \& Comments:

2

2

6

1

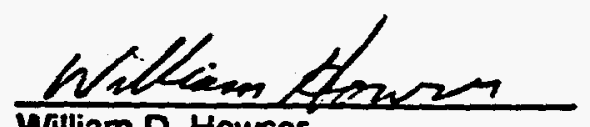

William D. Howser

Microscopist

MD = Nat Defected, trece $=4 \%$

These samples were analyzed in sccordance with the methodology in 40 CFR 700. Appendis A to Subpert F. These anelyees apply only lo the samples exalyzed.

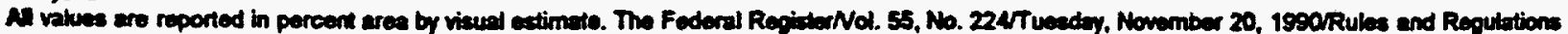

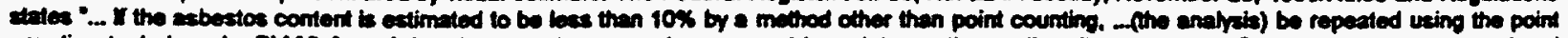

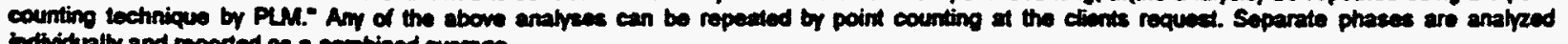
edividually and reported as a combined anerage. 


\section{LABORATORY REPORT \\ Bulk Sample Analysis For Asbestos by Polarized Light Microscopy}

Client: DSI Industries Consolidated, Inc. Site Reference: Laboratory ID Number.
DSI Provided

L1100222
Project Reference:

Date Analyzed:

METCKAAI

October 4, 1994

Page: 1

Client Sample \#

G-1-25

G-1-26

G-1-27

G-1-28

Macroscopic

Examination:

Color.

Texture:

Homogeneous:

Gross Description:

$\begin{array}{cc}\text { Brown/Green } & \text { Brown/Green } \\ \text { Amorphous } & \text { Amorphous } \\ \text { Y } & Y \\ \text { Filtered } & \text { Filtered } \\ \text { Product } & \text { Product }\end{array}$

$\begin{array}{cc}\begin{array}{c}\text { Brown/Green } \\ \text { Amorphous }\end{array} & \begin{array}{c}\text { Brown/Green } \\ \text { Amorphous }\end{array} \\ \begin{array}{cc}\text { Ym } \\ \text { Fittered }\end{array} & \text { Filtered } \\ \text { Product } & \text { Product }\end{array}$

Components:

Asbestos Minerals

\% Chrysotile

\% Amosite

\% Crocidolite

\% Tremolite

\% Actinolite

\% Anthophyllite

Total \% Asbestos:

ND

ND

ND

ND

Other Component Materials

$\%$ Cellulose

\% Mineral Wool

2

2

2

5

\% Fibrous Glass

\% Hair

\% Synthetic Fibers

\% Other Fibers

\% Resin/Binder

\% Other Components

Analysts Notes \& Comments:

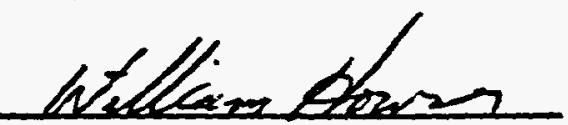

William D. Howser

Microscopist

ND = Mat Defected, trace $=4 \%$

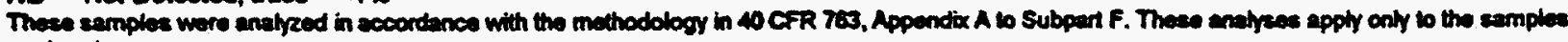
sialyed.

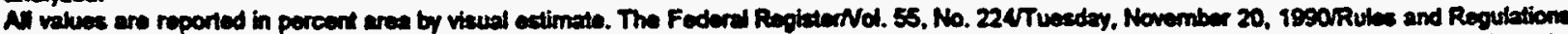

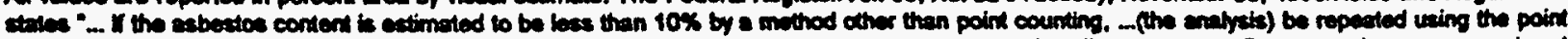

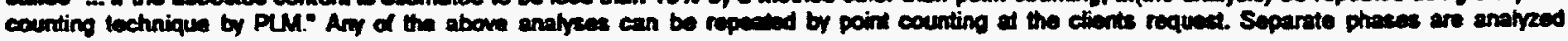
individually and reported as a combined merego. 


\section{LABORATORY REPORT}

\section{Bulk Sample Analysis For Asbestos by Polarized Light Microscopy}

Client: DSI Industries Consolidated, Inc.

Site Reference:

Laboratory ID Number.
DSI Provided

L1100222
Project Reference:

Date Analyzed:
METC/KAI

October 4, 1994

Page: 1

Client Sample \#

G-1-29

G-1-30

G-1-31

G-132

Macroscopic

Examination:

Color.

Texture:

Homogeneous:

Gross Description:

Brown/Green
Amorphous
$Y$
Filtered
Product

Brown/Green
Amorphous
Y
Filtered
Product

\section{Brown/Green \\ Amorphous \\ $Y$}

Filtered

Product
BrownGreen

Amorphous

$Y$

Filtered

Product

Components:

Asbestos Minerals

\% Chrysotile

\% Amosite

\% Crocidolite

\% Tremolite

\% Actinolite

\% Anthophyliite

Total \% Asbestos:

No

ND

ND

ND

Other Component Materials

\% Cellulose

3

4

3

4

\% Mineral Wool

\% Fibrous Glass

\% Hair

\% Synthetic Fibers

\% Other Fibers

\% Resin/Binder

\% Oher Components

97

86

97

86

Analysts Notes \& Comments:

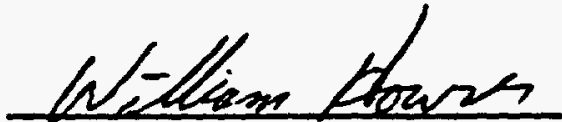

William D. Howser

Microscopist

ND = Nat Detected, trace $=4 \mathrm{~s}$

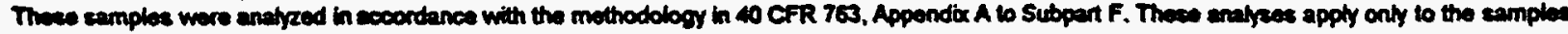
andred.

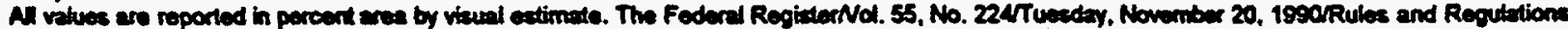

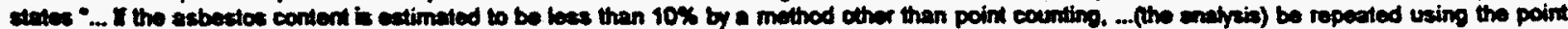

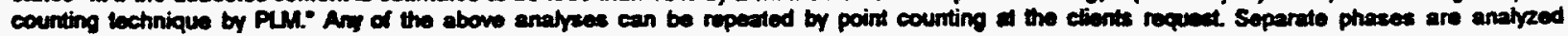
individually and reported es a contined ereres. 


\section{LABORATORY REPORT}

\section{Bulk Sample Analysis For Asbestos by Polarized Light Microscopy}

Client: DSI Industries Consolidated, Inc.

Site Reference:

Project Reference:

DSI Provided

L1100222

Date Analyzed:

METCKKAI

Laboratory ID Number.

October 4, 1994

Page: 1

Client Sample \#

GS-1-33

Macroscopic

Examination:

Color.

Texture:

Homogeneous:

Gross Description:

Brown/Green
Amorphous
Y
Filtered
Product

Components:

Asbestos Minerals

\% Chrysotile

$\%$ Amosite

$\%$ Crocidolite

$\%$ Tremolite

$\%$ Actinolite

\% Anthophyllite

Total \% Asbestos:

ND

Other Component Materials

$\%$ Cellulose

3

$\%$ Mineral Wool

\% Fibrous Glass

$\%$ Hair

\% Synthetic Fibers

$\%$ Other Fibers

$\%$ Resin/Binder

\% Other Components

97

Analysts Notes \& Comments:

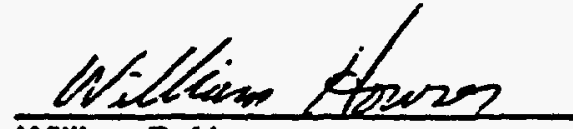

William D. Howser

Microscopist

NO = Not Detected, trece $=<1 \%$

These samples wore analyzed in scocordance vith the mothodolooy in 40 CFR 763, Appendix A to Subpert F. Thece analyes apply only to the samples malyeed.

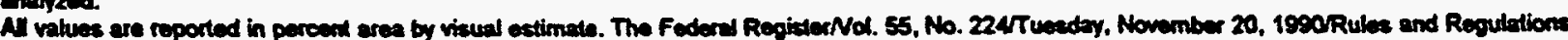

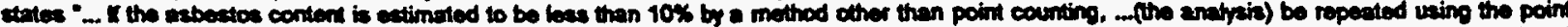

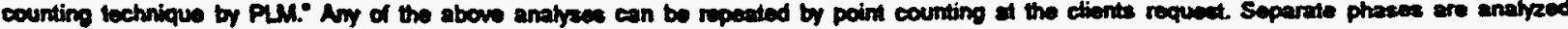
Individually and reported as a combined averaso. 